DIEGO MONTAGNINI MAZARIM

HISTÓRICO DAS PONTES ESTAIADAS

E SUA APLICAÇÃO NO BRASIL 
DIEGO MONTAGNINI MAZARIM

\section{HISTÓRICO DAS PONTES ESTAIADAS E SUA APLICAÇÃO NO BRASIL}

Dissertação apresentada à Escola Politécnica da Universidade de São Paulo para obtenção do título de Mestre em Engenharia

Área de Concentração:

Engenharia de Estruturas

Orientador:

Prof. Dr. Henrique Lindenberg Neto 
Este exemplar foi revisado e alterado em relação à versão original, sob responsabilidade única do autor e com a anuência de seu orientador.

São Paulo, 26 de agosto de 2011.

Assinatura do autor

Assinatura do orientador

FICHA CATALOGRÁFICA

Mazarim, Diego Montagnini

Histórico das pontes estaiadas e sua aplicação no Brasil /

D.M. Mazarim. -- ed.rev. -- São Paulo, 2011.

$125 \mathrm{p}$.

Dissertação (Mestrado) - Escola Politécnica da Universidade de São Paulo. Departamento de Engenharia de Estruturas e Geotécnica.

1. Pontes estaiadas - Brasil 2. História (Desenvolvimento) 3. Estruturas (Componentes) I. Universidade de São Paulo. Escola Politécnica. Departamento de Engenharia de Estruturas e Geotécnica II. t. 
Aos meus pais, que tanto me apoiaram em todos os momentos de minha vida, e a minha namorada, sempre ao meu lado com amor e carinho. 


\section{AGRADECIMENTOS}

Aos meus pais, por terem me apoiado nesta e em todas as etapas de minha vida, pela sua dedicação e amor, pelo constante apoio à realização dos meus sonhos e o ombro amigo nas horas difíceis de minha vida.

A minha namorada, que com seu amor, carinho e compreensão me ajudou nessa longa caminhada até a presente data, estando sempre presente ao meu lado me mostrando que sonhos podem virar realidade.

Ao meu orientador Henrique Lindenberg Neto, pela ajuda e valiosa orientação, sempre disposto a me ajudar e apoiar durante a execução do trabalho.

A todas as pessoas que ajudaram e colaboraram para o desenvolvimento do trabalho.

A Deus, que com sua bondade infinita iluminou meu caminho, mesmo nas horas mais difíceis. 


\section{RESUMO}

O princípio estrutural das pontes estaiadas não é tão recente quanto as pontes propriamente ditas. Em algumas estruturas, tais como passarelas, embarcações e tendas, já se usavam cabos como sustentação. Com a evolução da tecnologia e dos materiais, houve a possibilidade de um aperfeiçoamento dessas técnicas e sua utilização nas mais diversas áreas.

As pontes estaiadas surgiram como uma alternativa eficaz para transpor grandes vãos, possibilitando a utilização de estruturas mais leves, esbeltas e econômicas.

Este trabalho apresenta a evolução das pontes estaiadas no mundo e no Brasil, enfatizando os seus aspectos históricos, as novas tecnologias empregadas nestes projetos, as diversas possibilidades de geometria da estrutura e os métodos construtivos empregados nestas pontes..

Para as pontes estaiadas ao redor do mundo, é elaborada uma análise geral, demonstrando sua importância ao longo da história e as vantagens que as mesmas propiciaram para o suprimento das necessidades da humanidade.

Fazendo uma análise especial das pontes estaiadas brasileiras, é elaborada uma listagem das mesmas por ordem cronológica, indicando suas principais características.

Finalmente, para as pontes estaiadas nacionais de maior destaque, é feita uma análise mais detalhada das suas principais características quanto ao vão central, geometria da ponte, processo construtivo, curiosidades sobre 0 empreendimento e período de construção. 


\begin{abstract}
The structural principle of cable stayed bridges is not as recent as the bridges themselves. In some structures such as catwalks, boats and tents, cable were already used as a support. With the evolution of technology and materials, there was the possibility of an improvement of these techniques and their use in several areas.

The cable-stayed bridges have emerged as an effective alternative to largespan bridge, allowing the use of lighter, slim and economical structures. This paper presents the evolution of cable-stayed bridges in the world and in Brazil, emphasizing the historical aspects, the new technologies employed in these projects, the various possibilities for the geometry of the structure and the construction methods employed in these bridges.

A general analysis of cable stayed bridges around the world is done, being shown their importance throughout history and the advantages that they have brought to fulfill the needs of mankind

A special analysis of cable stayed bridges in Brazil will be is made a list of them in a chronological order is presented and their main features are examined.

Finally, for the most prominent Brazilian cable stayed bridges national prominence, a more detailed analysis of its key features is done, being examined the central span, the bridge geometry, the constructive process, curiosities about the new development and the construction period.
\end{abstract}




\section{SUMÁRIO}

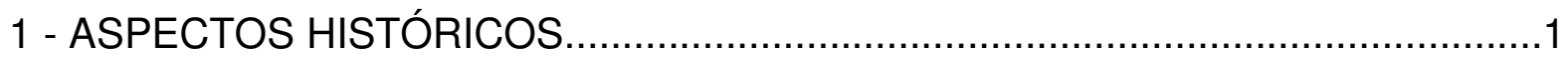

1.1 - ASPECTOS HISTÓRICOS DAS PONTES ESTAIADAS ................................1

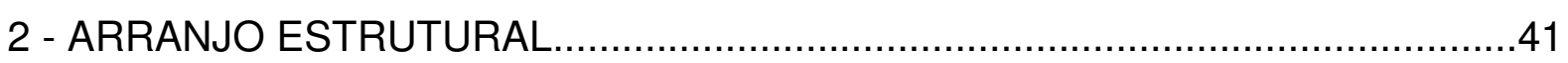

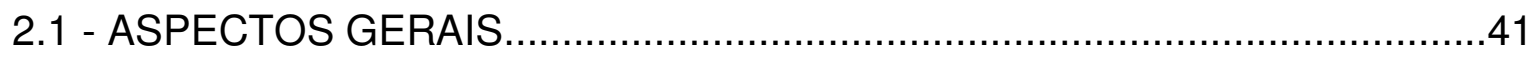

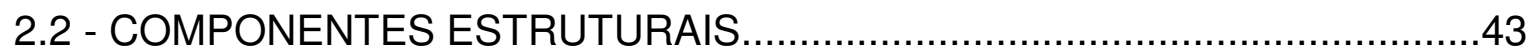

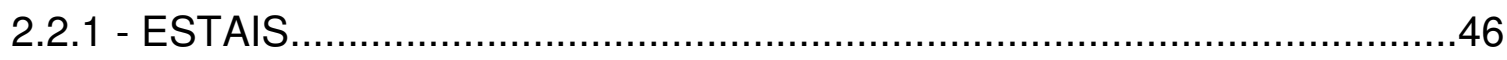

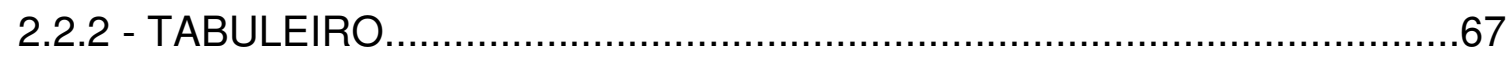

2.2.2.1- TABULEIRO DE CONCRETO.................................................68

2.2.2.2- TABULEIRO METÁLICO........................................................73

2.2.2.3- TABULEIRO MISTO DE CONCRETO E AÇO...............................74

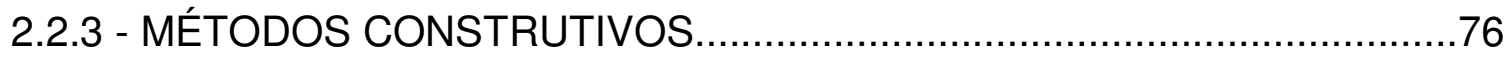

3 - APLICAÇÃO DAS PONTES ESTAIADAS NO BRASIL....................................79

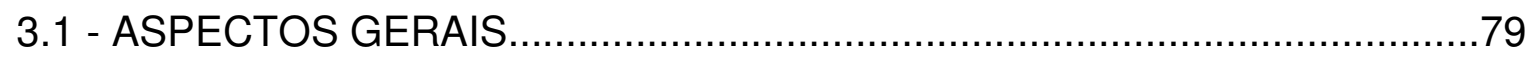

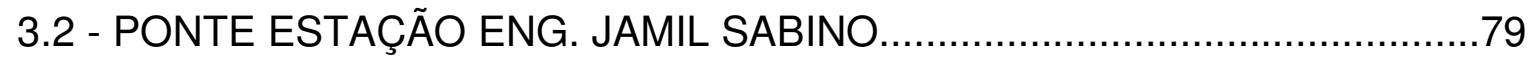

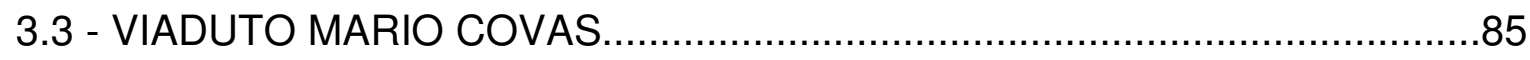

3.4 - PONTE SERGIO MOTTA

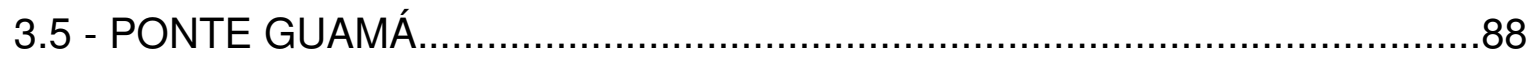

3.6 - PONTE DE INTEGRAÇÃO BRASIL - PERU.........................................

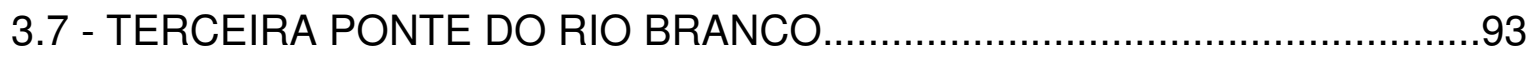

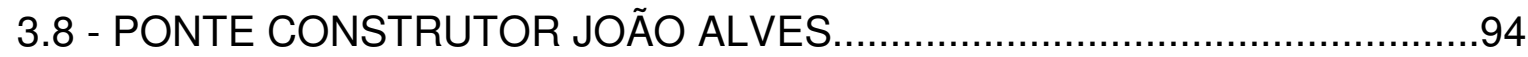

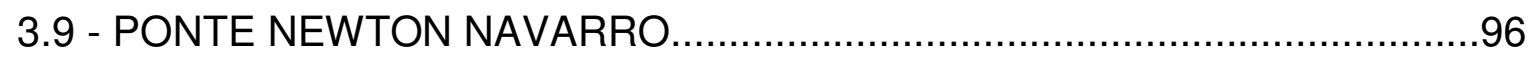




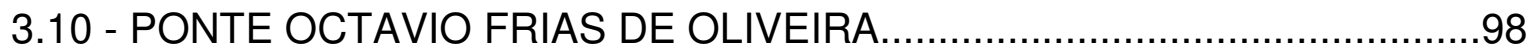

3.11 - PONTE ESTAIADA SOBRE O RIO PARANÁ.........................................106

3.12 - PONTE ESTAIADA JOÃO ISIDORO FRANÇA.......................................109

3.13 - PONTE SOBRE O RIO NEGRO.......................................................111

3.14 - PASSARELA JOAQUIM FALCÃO MACEDO..........................................114

3.15 - DEMAIS PONTES ESTAIADAS BRASILEIRAS....................................115

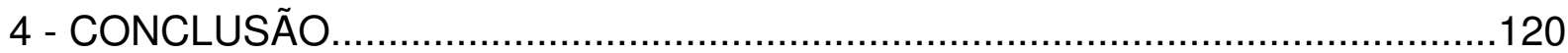

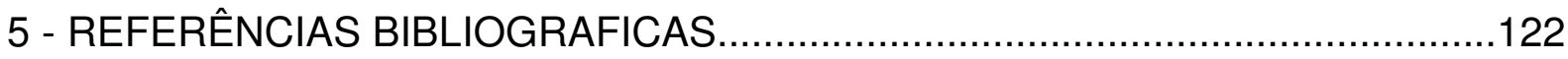




\section{LISTA DE ILUSTRAÇÕES}

Figura 1.1 - Embarcação egípcia construída com estais sustentando vigas..............1

Figura 1.2 - Ponte estaiada de madeira........................................................

Figura 1.3 - Construção da Ponte Tacoma Narrows..........................................

Figura 1.4 - Oscilação torsional da Ponte Tacoma Narrows.....................................4

Figura 1.5 - Movimento torsional da Ponte Tacoma Narrows...............................4

Figura 1.6 - Modelo da nova ponte de Tacoma no Túnel de Vento na Universidade

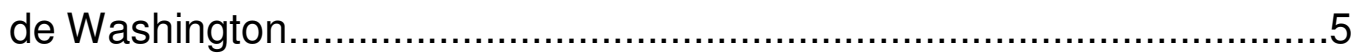

Figura 1.7 - Detalhe das ancoragens dos cabos durante a construção da Ponte do

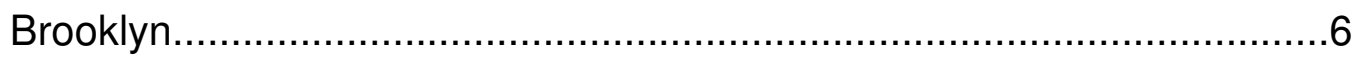

Figura 1.8 - Ponte do Brooklyn, nos Estados Unidos........................................

Figura 1.9 - Ponte de Strömsund, na Suécia..................................................

Figura 1.10 - Ponte de Strömsund, na Suécia............................................

Figura 1.11 - Ponte Donzère-Mondragon, na França........................................

Figura 1.12 - Ponte de Theodor Heuss, na Alemanha......................................11

Figura 1.13 - Ponte de Theodor Heuss, na Alemanha.......................................12

Figura 1.14 - Ponte Knee, na Alemanha..................................................13

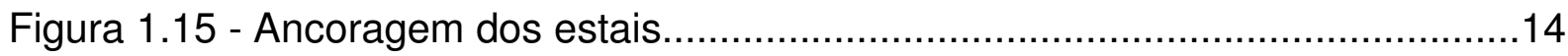

Figura 1.16 - Ponte Oberkassel, na Alemanha....................................................14

Figura 1.17 - Antiga Ponte Oberkassel.......................................................15

Figura 1.18 - Ponte Maracaibo, na Venezuela..............................................15

Figura 1.19 - Construção da Ponte Maracaibo...............................................16

Figura 1.20 - Construção da Ponte Maracaibo..............................................17

Figura 1.21 - Corte longitudinal da Ponte Maracaibo.......................................17

Figura 1.22 - Ponte Wadri-Kuf, na Libia.......................................................18

Figura 1.23 - Ponte Wadri-Kuf, na Libia..................................................19 
Figura 1.24 - Ponte Friedrich Ebert, na Alemanha...........................................19

Figura 1.25 - Ponte Friedrich Ebert, na Alemanha.............................................20

Figura 1.26 - Ponte Disseldorf Flehe, na Alemanha.............................................21

Figura 1.27 - Ponte Disseldorf Flehe, na Alemanha............................................22

Figura 1.28 - Ponte Brotonne, na França...........................................................23

Figura 1.29 - Construção da Ponte Brotonne, na França........................................24

Figura 1.30 - Ponte Saint-Nazaire, na França.......................................................26

Figura 1.31 - Construção da Ponte Saint-Nazaire ................................................26

Figura 1.32 - Ponte Barrios de Luna, na Espanha................................................27

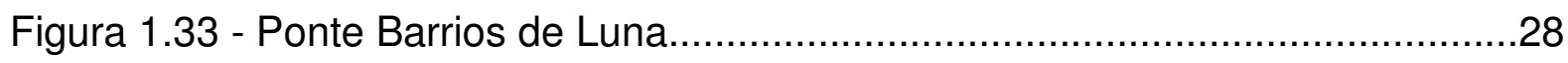

Figura 1.34 - Ponte Alex Fraser, no Canada..........................................................28

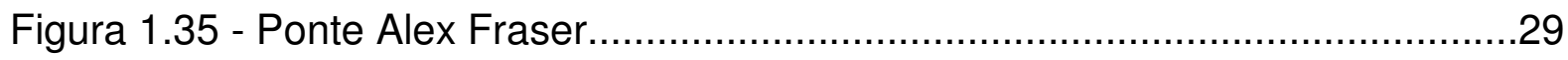

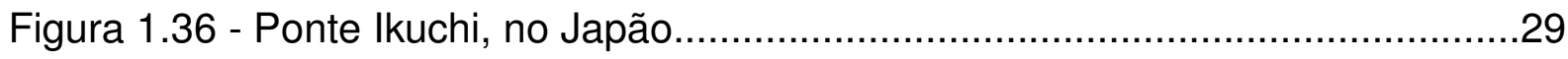

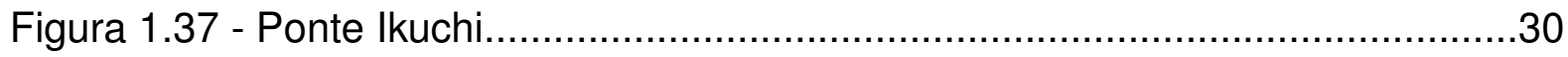

Figura 1.38 - Ponte Skarnsundet, na Noruega ……….........................................

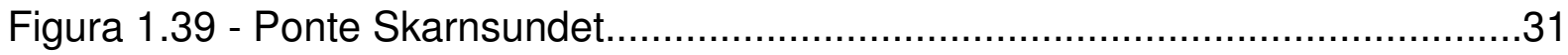

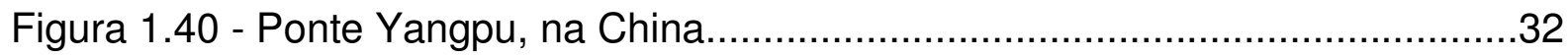

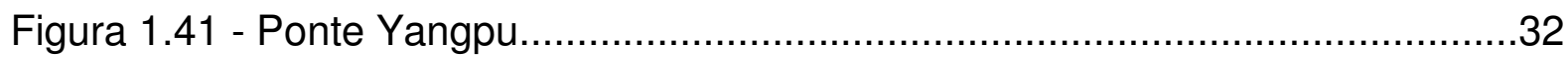

Figura 1.42 - Ponte da Normandia, na França.....................................................33

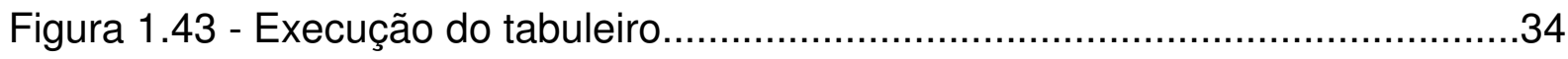

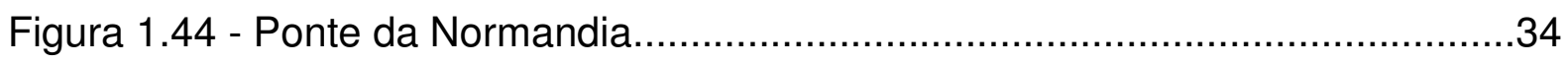

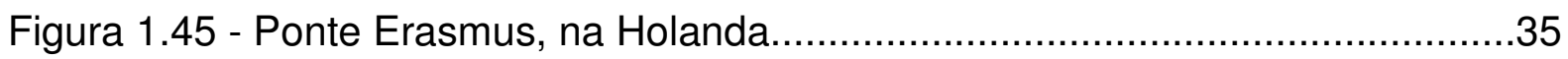

Figura 1.46 - Detalhe da passagem dos estais pelo mastro da Ponte Erasmus.........36

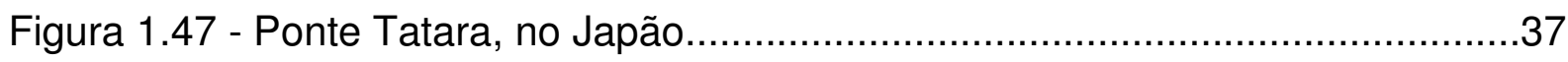

Figura 1.48 - Construção da Ponte Tatara.............................................................37

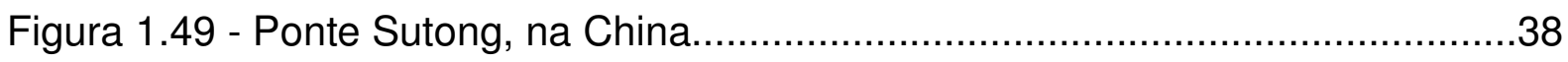

Figura 1.50 - Maquete da construção da Ponte Sutong.........................................39 
Figura 1.51 - Construção da Ponte Sutong. 39

Figura 2.1 - Embarcação antiga .41

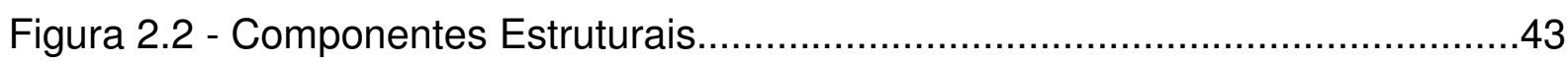

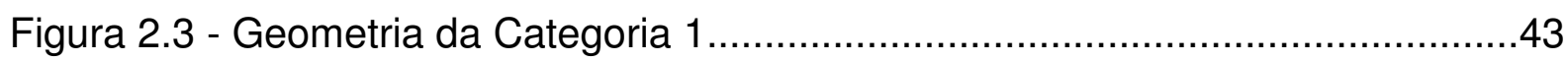

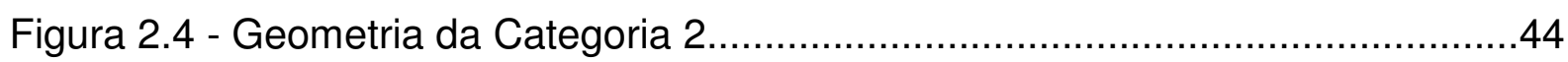

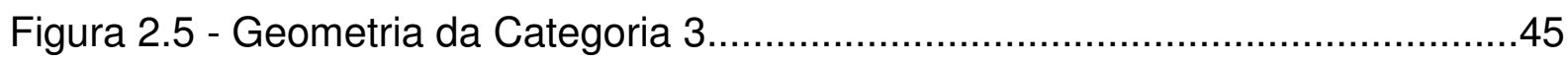

Figura 2.6 - Esforços atuantes nas pontes estaiadas da Categoria 3........................45

Figura 2.7 - Componentes dos estais - Ponte Octavio Frias de Oliveira....................47

Figura 2.8 - Exemplo da seção de cordoalhas........................................................48

Figura 2.9 - Sistema de ancoragem e proteção de um estai......................................49

Figura 2.10 - Distribuição em um plano vertical...................................................50

Figura 2.11 - Efeito de torção na distribuição de estais em um plano vertical...........51

Figura 2.12 - Ponte Skarnsundet, na Noruega ......................................................52

Figura 2.13 - Distribuição em dois planos verticais...............................................53

Figura 2.14 - Esquema de cargas para pontes com dois planos verticais.................54

Figura 2.15 - Distribuição em três planos verticais...................................................54

Figura 2.16 - Distribuição em dois planos inclinados.............................................55

Figura 2.17 - Interferência dos estais no gabarito da via.......................................56

Figura 2.18 - Geometria em Harpa.................................................................

Figura 2.19 - Forças atuantes na geometria em harpa...........................................57

Figura 2.20 - Forças assimétricas atuantes na geometria em harpa........................58

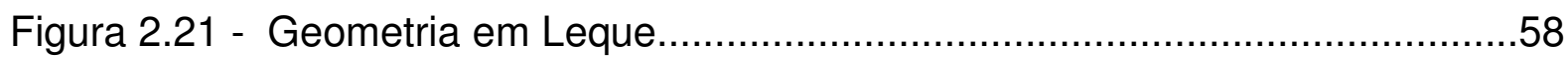

Figura 2.22 - Ponte em Leque - Pasco-Kennewich.............................................59

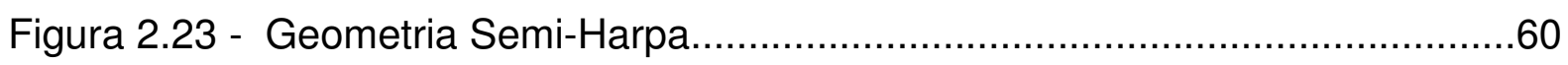

Figura 2.24 - Geometria de Semi-Harpa da Ponte sobre o Rio Paranaíba.................60

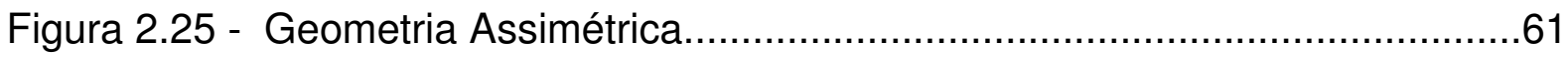


Figura 2.26 - Esquema de cargas para a geometria assimétrica 61

Figura 2.27 - Ponte Octavio Frias de Oliveira - São Paulo........................................62

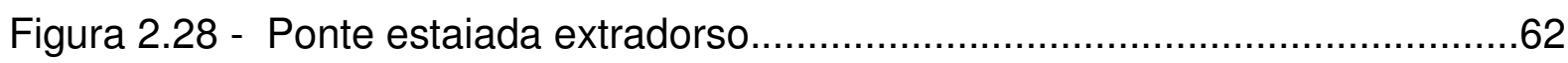

Figura 2.29 - Esforços na ponte estaiada extradorso.............................................63

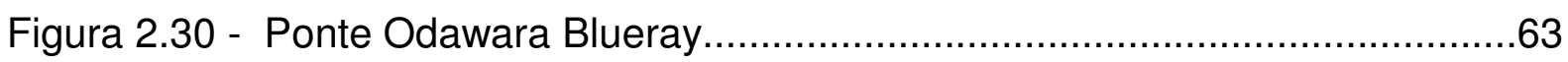

Figura 2.31 - Ponte estaiada com múltiplos vãos................................................64

Figura 2.32 - Viaduto de Millau - França..........................................................64

Figura 2.33 - Nuvens encobrindo o Viaduto de Millau - França.................................65

Figura 2.34 - Tabuleiro em execução ……………………………………......66

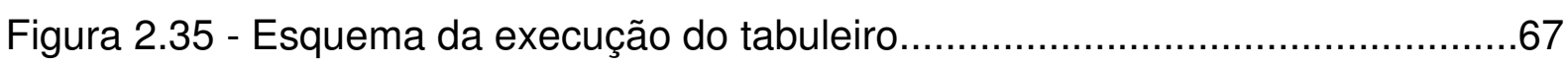

Figura 2.36 - Içamento de tabuleiro pré-moldado...................................................68

Figura 2.37 - Método das aduelas sucessivas....................................................69

Figura 2.38 - Ponte Maracaibo - Venezuela........................................................

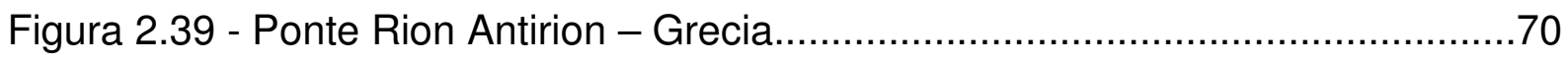

Figura 2.40 - Seção vazada de concreto protendido..............................................71

Figura 2.42 - Ponte Brotonne - França............................................................

Figura 2.42 - Seção da ponte Barrios de Luna........................................................72

Figura 2.43 - Ponte Stonecutters....................................................................

Figura 2.44 - Construção da Ponte Stonecutters..................................................74

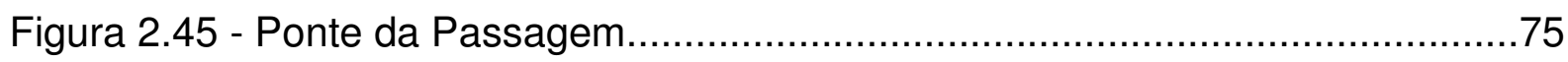

Figura 2.46 - Vista lateral de tabuleiro executado com escoramentos......................76

Figura 2.47 - Vista lateral de tabuleiro executado através do método dos balanços sucessivos. .77

Figura 2.48 - Vista lateral de tabuleiro executado através do método dos balanços sucessivos com elementos pré-moldados. 


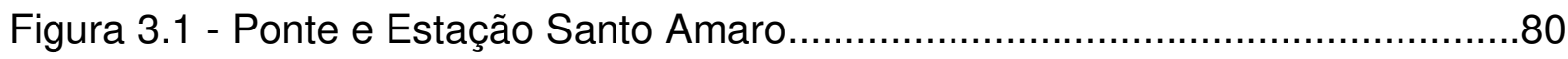

Figura 3.2 - Vista interna da Ponte e Estação Santo Amaro.......................................80

Figura 3.3 - Vista de Satélite da Ponte e Estação Santo Amaro.................................81

Figura 3.4 - Vista lateral da Ponte e Estação Estaiada Santo....................................81

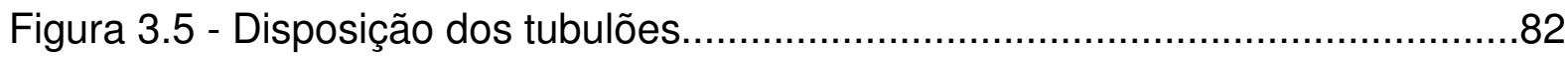

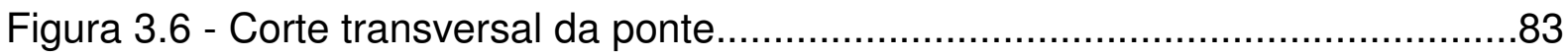

Figura 3.7 - Espaçamentos distintos dos estais....................................................83

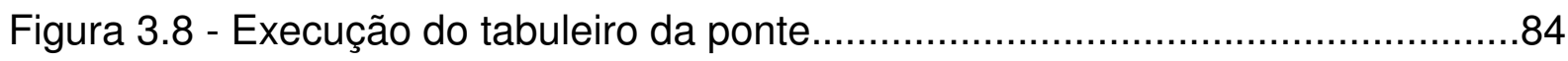

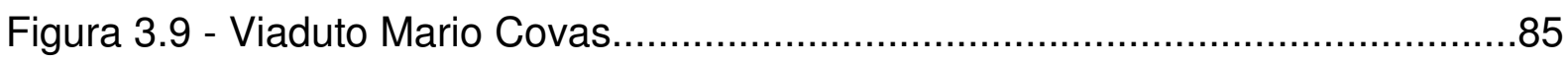

Figura 3.10 - Vista de Satélite do Viaduto Mario Covas.............................................86

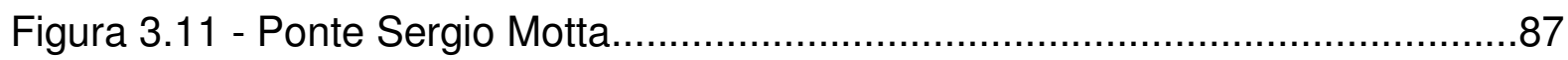

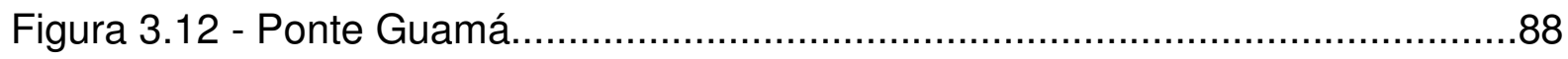

Figura 3.13 - Construção do trecho estaiado da Ponte Guamá..................................89

Figura 3.14 - Vista dos estais da Ponte Guamá.....................................................89

Figura 3.15 - Vista dos estais da Ponte Guamá...................................................89

Figura 3.15 - Modelo do tabuleiro ensaiado em túnel de vento no Laboratório de Aerodinâmica das Construções da UFRGS.......................................90

Figura 3.16 - Ponte de Integração Brasil - Peru......................................................91

Figura 3.17 - Corte longitudinal da Ponte de Integração Brasil - Peru......................91

Figura 3.18 - Vista de Satélite da Ponte de Integração Brasil Peru...........................92

Figura 3.19 - Vista dos estais da Ponte de Integração Brasil Peru............................92

Figura 3.20 - Terceira Ponte do Rio Branco.........................................................93

Figura 3.21 - Corte longitudinal da Terceira Ponte do Rio Branco ...........................93

Figura 3.22 - Ponte Construtor João Alves........................................................94

Figura 3.23 - Ponte Construtor João Alves..............................................................

Figura 3.24 - Construção do trecho estaiado da Ponte Construtor João Alves..........95

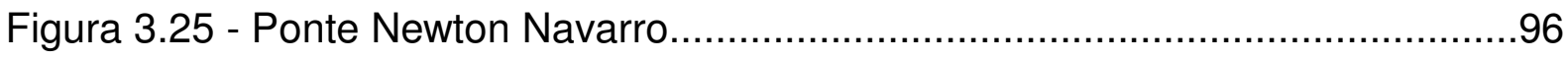


Figura 3.26 - Vista de Satélite da Ponte Newton Navarro......................................97

Figura 3.27 - Construção da Ponte Newton Navarro...............................................97

Figura 3.28 - Vista de satélite da Ponte Octavio Frias de Oliveira.............................98

Figura 3.29 - Ilustração artística do Projeto Básico..................................................99

Figura 3.30- Ponte Octavio Frias de Oliveira.....................................................99

Figura 3.31 - Construção dos mastros da Ponte Octavio Frias de Oliveira..............100

Figura 3.32 - Método das aduelas sucessivas....................................................101

Figura 3.33 - Ensaio em Túnel de Vento.................................................................101

Figura 3.34 - Seção do tabuleiro ......................................................................102

Figura 3.35 - Mastro da Ponte Octavio Fria de Oliveira.........................................102

Figura 3.36 - Chegada do estai no tabuleiro....................................................103

Figura 3.37 - Cruzamento dos Estais...........................................................104

Figura 3.38 - Execução do tabuleiro através do método dos balanços sucessivos 104

Figura 3.39 - Execução dos tabuleiros .........................................................105

Figura 3.40 - Ponte sobre o Rio Paraná ...........................................................106

Figura 3.41 - Geometria da Ponte sobre o Rio Paraná..............................................106

Figura 3.42 - Vista de satélite da construção da Ponte sobre o Rio Paraná.............107

Figura 3.43 - Execução do trecho estaiado...................................................107

Figura 3.44 - Modelo do tabuleiro ensaiado em túnel de vento no Laboratório de Aerodinâmica das Construções da UFRGS......................................108

Figura 3.45 - Ponte Estaiada João Isidoro França...............................................109

Figura 3.46 - Execução do tabuleiro da Ponte João Isidoro França.........................110

Figura 3.47 - Execução do tabuleiro estaiado....................................................110

Figura 3.48 - Perspectiva artística da Ponte sobre o Rio Negro..............................111

Figura 3.49 - Ilustração da ponte sobre a foto de satélite.......................................111

Figura 3.50 - Geometria do trecho estaiado....................................................112 
Figura 3.51 - Içamento dos elementos pré moldados.........................................112

Figura 3.52 - Geometria do tabuleiro no trecho estaiado.....................................113

Figura 3.53 - Situação da ponte em janeiro de 2011 ...........................................113

Figura 3.54 - Passarela Joaquim Falcão Macedo...............................................114

Figura 3.55 - Ponte Irineu Bornhausen........................................................115

Figura 3.56 - Viaduto Estaiado Cidade de Guarulhos..............................................116

Figura 3.57 - Vista artística da Ponte estaiada sobre o Rio Tietê.............................116

Figura 3.58 - Construção da Ponte estaiada sobre o Rio Tietê...............................117

Figura 3.59 - Construção do Viaduto Estaiado Padre Adelino.................................117

Figura 3.60 - Vista do Viaduto Estaiado Padre Adelino..........................................118

Figura 3.61 - Perspectiva artística da Ponte Estaiada de Barueri...........................118

Figura 3.62 - Perspectiva artística da Ponte Estaiada de Barueri...........................119 


\section{LISTA DE GRÁFICOS}

Gráfico 1.1 - Vãos atingidos pelas pontes estaiadas nos últimos 50 anos... 


\section{ASPECTOS HISTÓRICOS}

\subsection{ASPECTOS HISTÓRICOS DAS PONTES ESTAIADAS}

O princípio estrutural das pontes estaiadas vem de longa data. As estruturas suportadas por cabos, cordas ou correntes vêm se mostrando uma solução interessante desde as antigas civilizações até atualmente.

Exemplos significativos deste fato são: a utilização de cordas pelos egípcios para a sustentação dos mastros de suas embarcações e dos índios norte americanos que construíam passarelas de madeiras sustentadas por cordas.

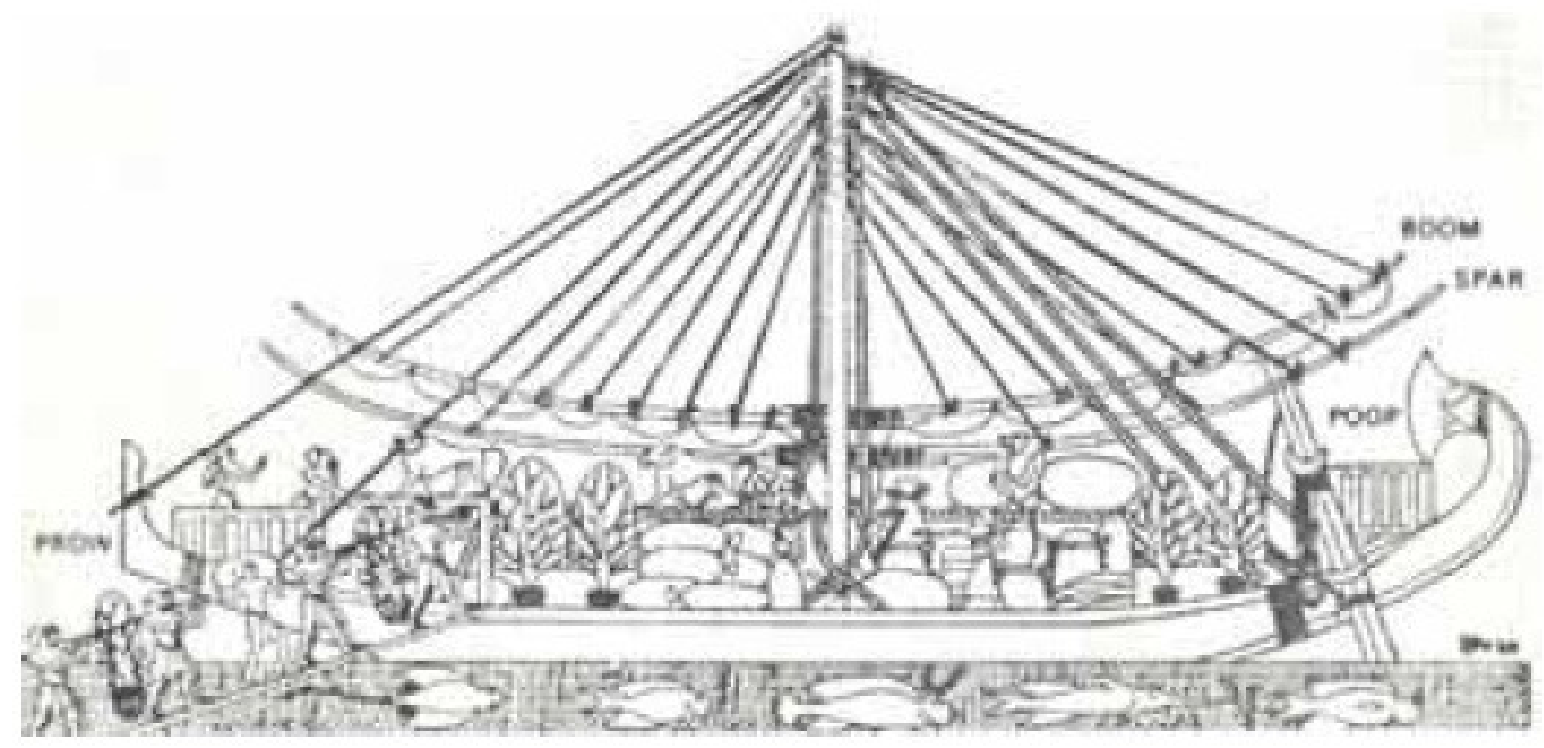

Figura 1.1 - Embarcação egípcia construída com estais sustentando vigas (TROITSKY, 1977)

E não são só estes exemplos. Inúmeros estudos e tentativas foram feitos ao longo da história, mas as primeiras tentativas de se construir uma ponte estaiada propriamente dita foram em 1784, com o projeto do carpinteiro alemão C. T. Lescher, o qual projetou uma ponte com estrutura estaiada inteiramente em madeira, conforme mostrado na figura 1.2 . 


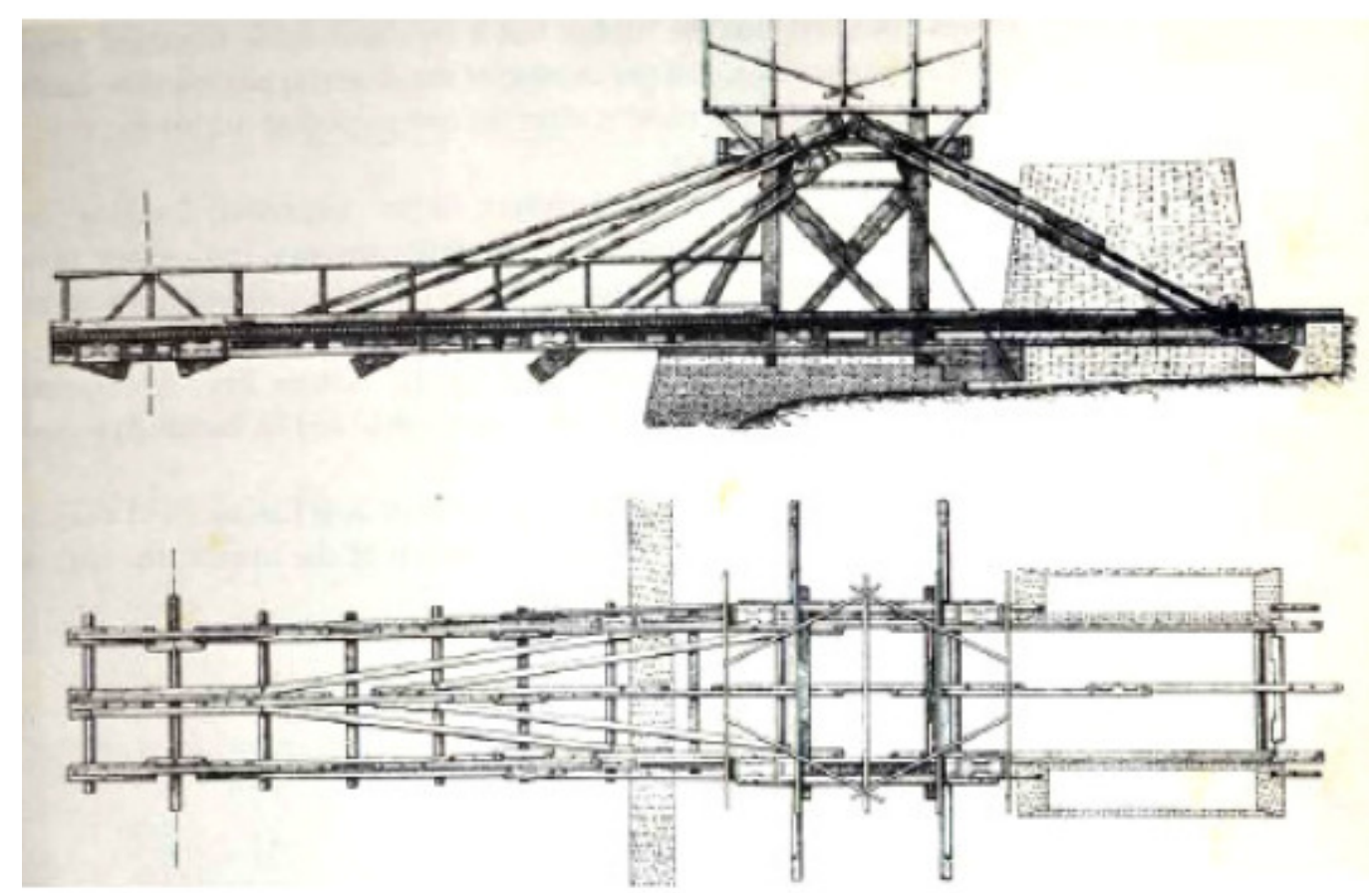

Figura 1.2 - Ponte estaiada de madeira (TROITSKY, 1977)

Com o avanço das ligas metálicas, estas soluções começaram a se tornar mais viáveis e capazes de suportar maiores esforços e, como conseqüência, maiores vãos.

Em 1817, a passarela estaiada de pedestres de King's Meadow foi projetada e construída por Brown e Redpath, dois engenheiros britânicos.

Nos anos seguintes, arquitetos e engenheiros foram concebendo, projetando e executando estruturas com diversas formas, principalmente para o arranjo dos cabos, sendo os arranjos em leque e harpa os que mais se destacaram.

Com isso, o século XVIII foi marcado pelo surgimento das pontes estaiadas modernas, construídas nos Estados Unidos e na Inglaterra.

Apesar de diversas estruturas apresentarem um comportamento estrutural dentro do esperado, alguns acidentes foram decisivos para o parcial abandono desta técnica durante muitos anos.

Estes acidentes envolvendo as pontes estaiadas, e também as pontes pênseis, ocorreram principalmente pela falta de conhecimento dos aspectos aerodinâmicos destas estruturas. A maneira como o vento provoca efeitos de vibração e ressonância no tabuleiro e principalmente nos estais foi uma incógnita durante muitos anos. 
$\mathrm{O}$ aperfeiçoamento das pontes estaiadas ocorreu em paralelo com o das pontes pênseis, uma vez que ambas sofriam do mesmo problema: como garantir um conjunto estável e rígido o suficiente para evitar deslocamentos excessivos provocados pela passagem do vento ou pela atuação de uma carga útil.

Um exemplo clássico da história da engenharia foi a ponte de Tacoma Narrows, inaugurada no estado de Washington, nos Estados Unidos, em 1940.

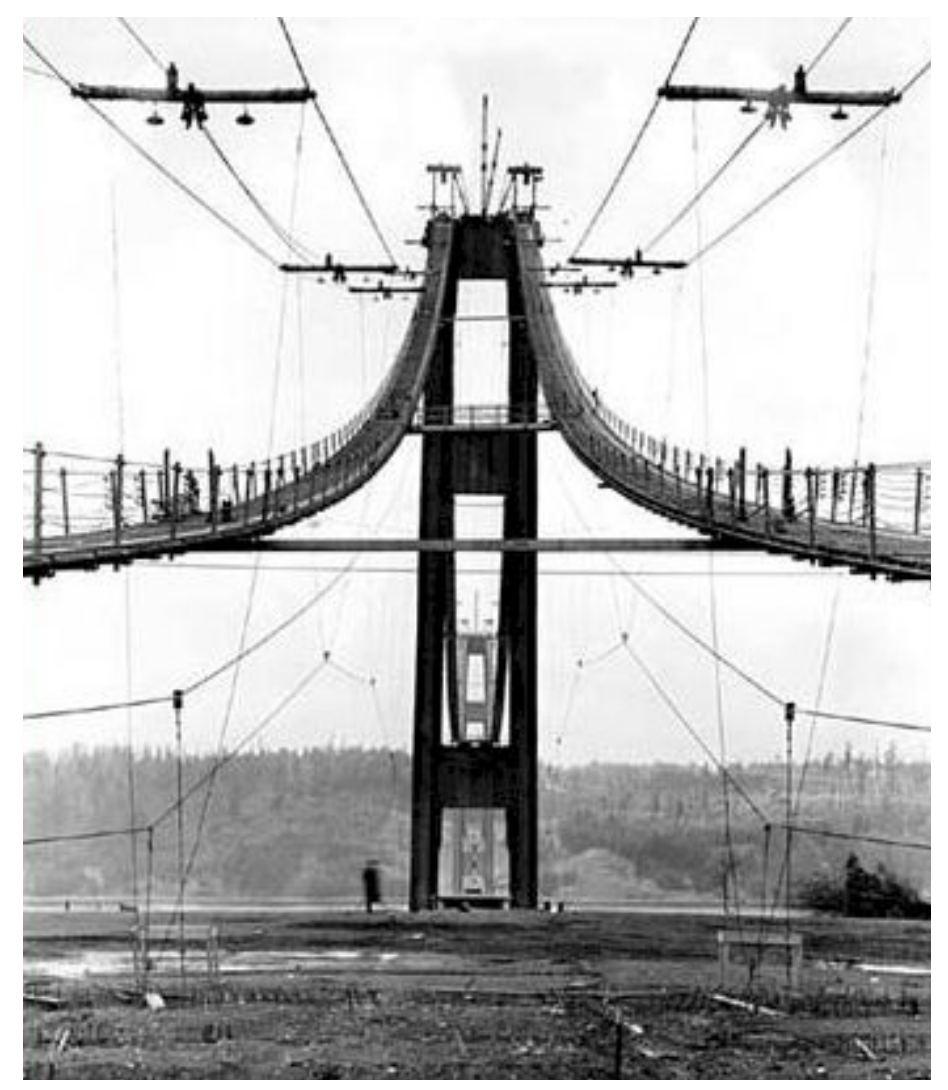

Figura 1.3 - Construção da Ponte Tacoma Narrows

(University of Washington - http://www.lib.washington.edu/specialcoll/exhibits/tnb)

Esta ponte pênsil, de estrutura relativamente esbelta e de grande vão livre, considerando os padrões da época, apresentou deficiência estrutural sob a ação do vento. Ainda na fase final de sua construção, a ponte de Tacoma já apresentava oscilações excessivas, e pouco tempo após a sua inauguração, no dia 7 de novembro de 1940, a ponte entrou em colapso sob a ação de um vento de apenas $65 \mathrm{~km} / \mathrm{h}$, que provocou oscilações torsionais no tabuleiro e, como consequência, deslocamentos excessivos do conjunto que culminaram no colapso da ponte. Apesar da gravidade do acidente, nenhuma pessoa se feriu. 


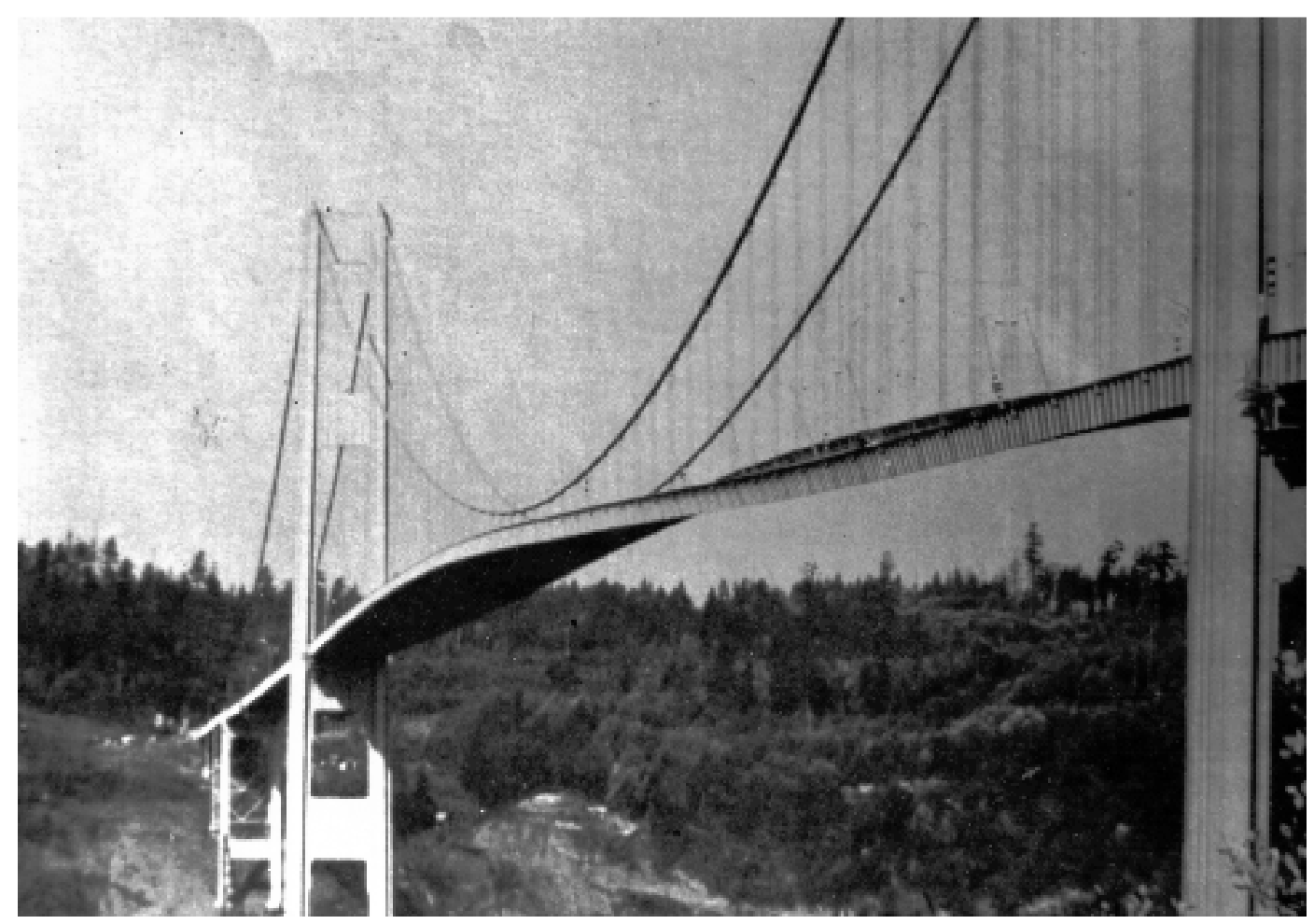

Figura 1.4 - Oscilação torsional da Ponte Tacoma Narrows

(University of BristoL - http://www.enm.bris.ac.uk/anm/tacoma/tacoma.html)

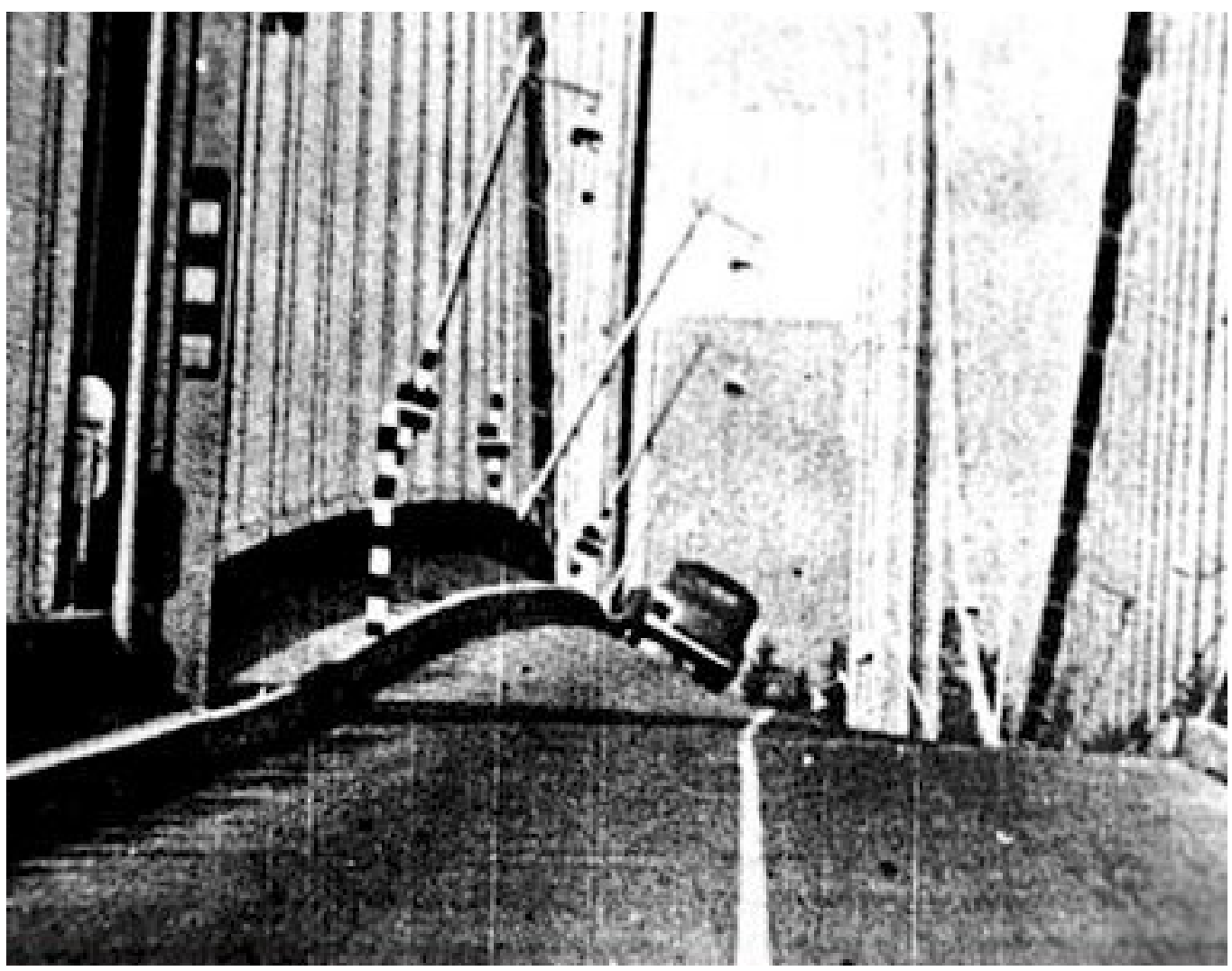

Figura 1.5 - Movimento torcional da Ponte Tacoma Narrows

(University of Washington - http://www.lib.washington.edu/specialcoll/exhibits/tnb/page4.html) 
Nos anos seguintes, uma equipe de engenheiros projetou a nova Ponte de Tacoma, realizando um novo cálculo estrutural, com o auxilio de ensaios em túnel de vento. Para que estes ensaios fossem possíveis de serem realizados foi construído um túnel de vento em madeira, no Laboratório de Pesquisas Estruturais da Universidade de Washington, nos EUA.

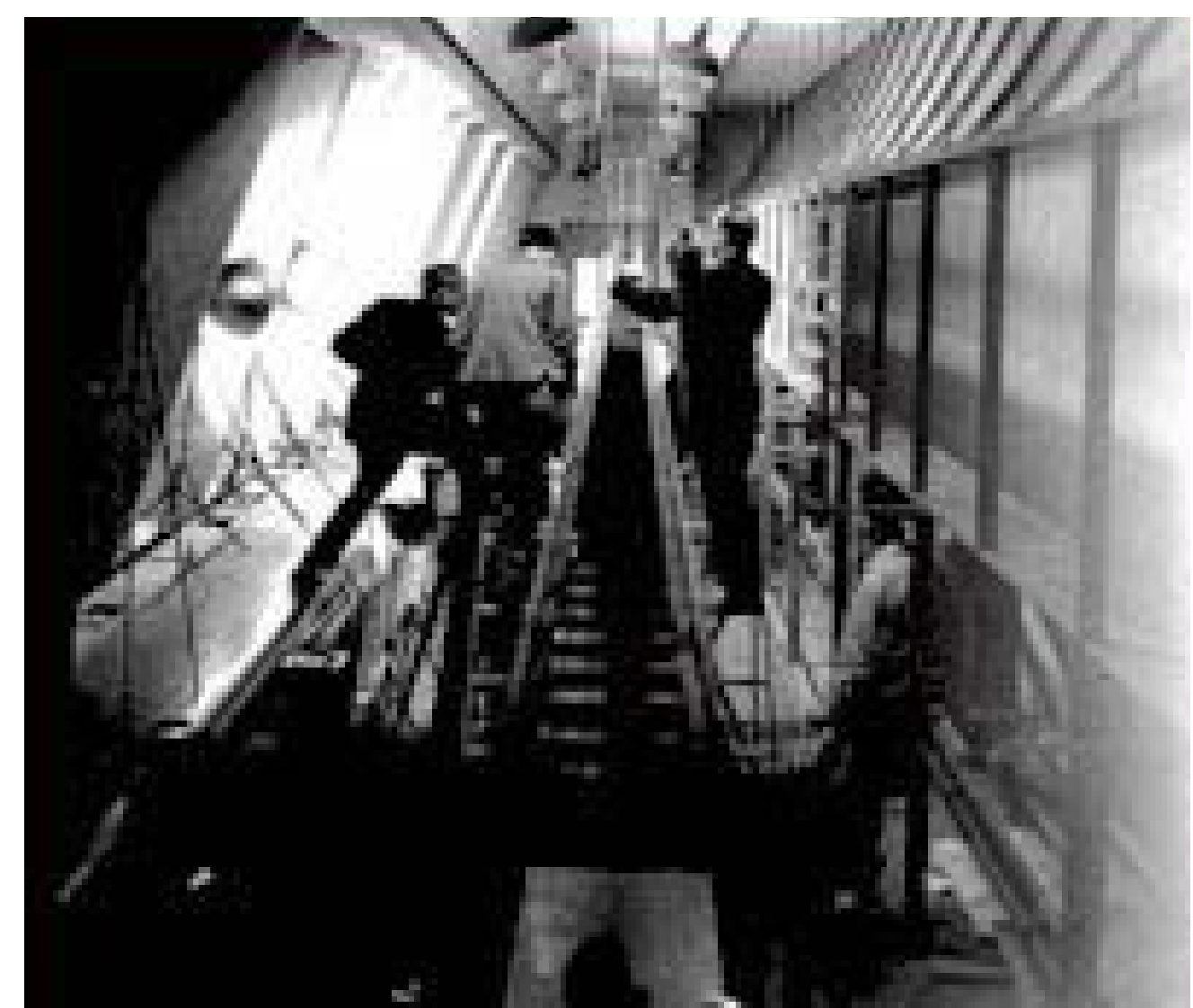

Figura 1.6 - Modelo da nova ponte de Tacoma no Túnel de Vento na Universidade de Washington (University of Washington - http://www.lib.washington.edu/specialcoll/exhibits/tnb/page6.html)

Após este incidente, entre outros, a metodologia para a concepção e dimensionamento de estruturas deste tipo teve de ser reelaborada, e a credibilidade neste tipo de solução estrutural demorou décadas para retomar seu prestígio inicial.

Com a construção de pontes de estrutura mista, que utilizam sistemas de cabos pênseis e estais, as quais se tornaram grandes marcos da história da construção civil, a solução de pontes exclusivamente estaiadas foi abandonada por um grande período. 
Um exemplo deste tipo de solução estrutural, que se tornou um exemplo notável desta época, é a ponte do Brooklyn, em Nova York. Projetada por John Roebling, esta ponte tem um vão central de $486,50 \mathrm{~m}$, e um comprimento total de $1059,90 \mathrm{~m}$. Roebling concebeu esta estrutura de maneira que o trecho central do vão fosse sustentado completamente pelos cabos parabólicos e os trechos próximos aos pilares, por estais protendidos. Os pilares da ponte do Brooklyn foram executados em alvenaria de pedras uma vez que não se tinha o domínio do concreto armado nesse período.

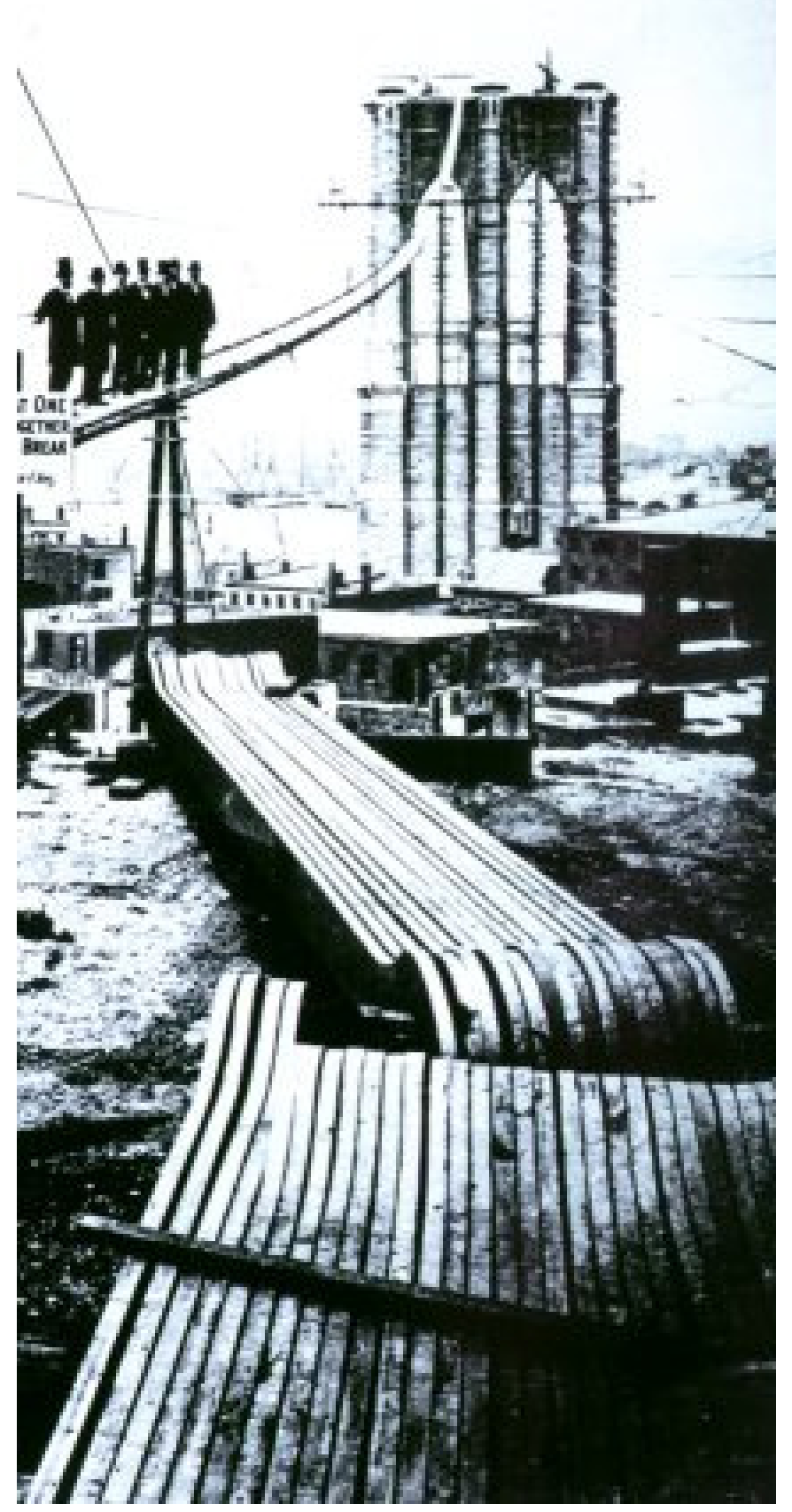

Figura 1.7-Detalhe das ancoragens dos cabos durante a construção da Ponte do Brooklyn (http://www.Imc.ep.usp.br/people/hlinde/estruturas/brooklin.htm) 
Essa estrutura hiperestática foi concebida e executada apenas com 0 conhecimento de J. Roebling, uma vez que nesta época não havia metodologias para cálculo de dimensionamento deste tipo de estrutura. Notou-se que os estais inclinados protendidos aumentaram consideravelmente a rigidez de pontes suspensas, tal como essa, além de contribuírem para sua estabilidade aerodinâmica. Roebling faleceu no ano de 1869, após adoecer de infecções originadas de um acidente ocorrido durante a construção da ponte, e seu filho, Washington Roebling, e sua esposa, Emily Roebling, deram continuidade e finalizaram o projeto da ponte.

A construção da ponte do Brooklyn demorou 14 anos, tendo sido concluída no ano de 1883, com um custo de aproximadamente 15 milhões de dólares.

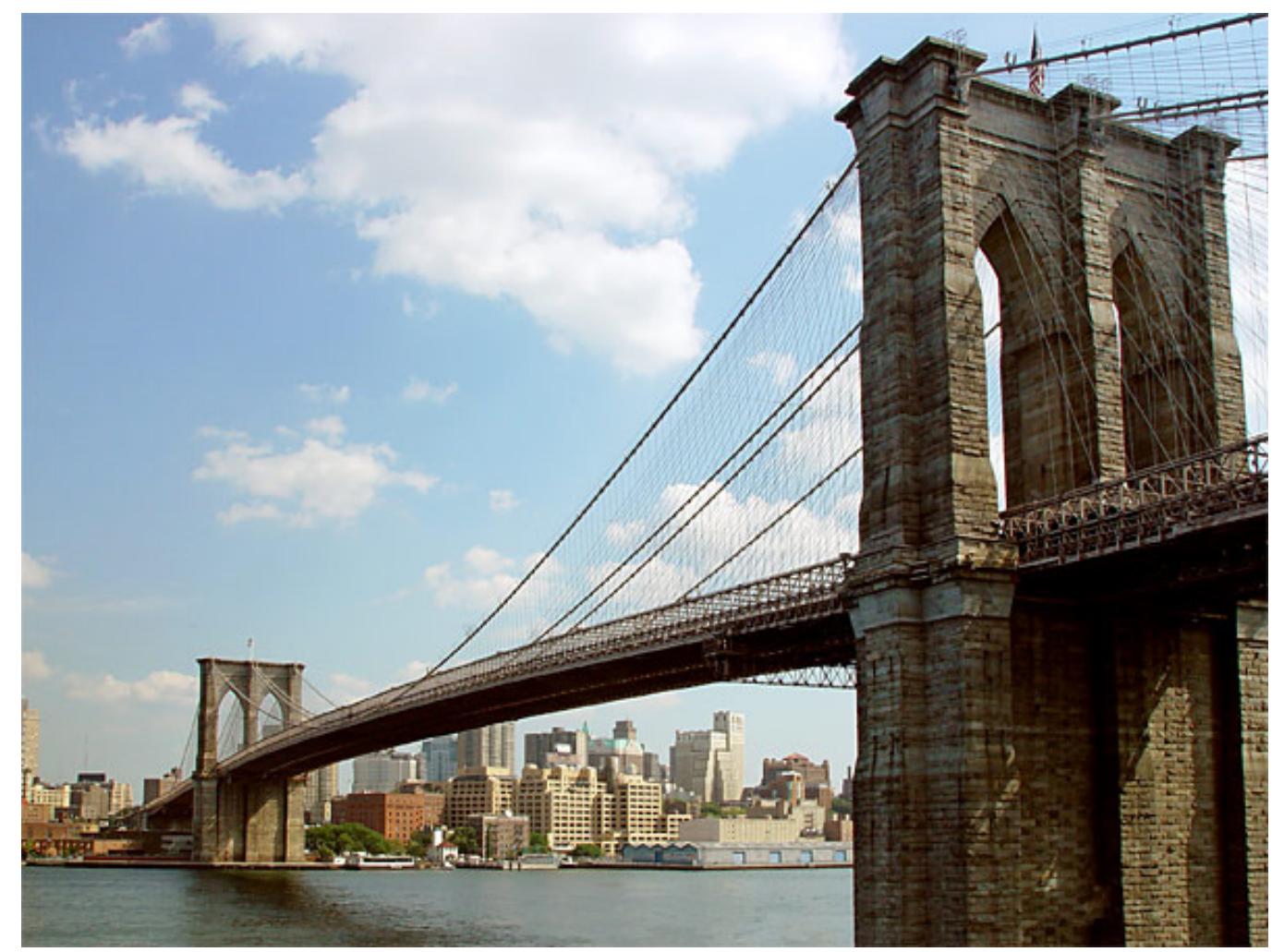

Figura 1.8 - Ponte do Brooklyn, nos Estados Unidos (http://structure-structuralsoftware.blogspot.com/2010/10/construction-of-brooklyn-bridge.html)

Em 1938, o engenheiro alemão Franz Dischinger tornou-se a peça chave para o desenvolvimento das pontes estaiadas. Após estudar as diversas pontes penseis e estaiadas já construídas, assim como os benefícios da utilização da solução conjunta de estais e cabos penseis, e também da utilização de estais protendidos, Dischinger concebeu e projetou a ponte Stromsund (Figura 1.5), na Suécia, que só 
teve suas obras concluídas em 1955. Sua estrutura é inteiramente em aço, com exceção da fundação, e vence um vão central de $182 \mathrm{~m}$.

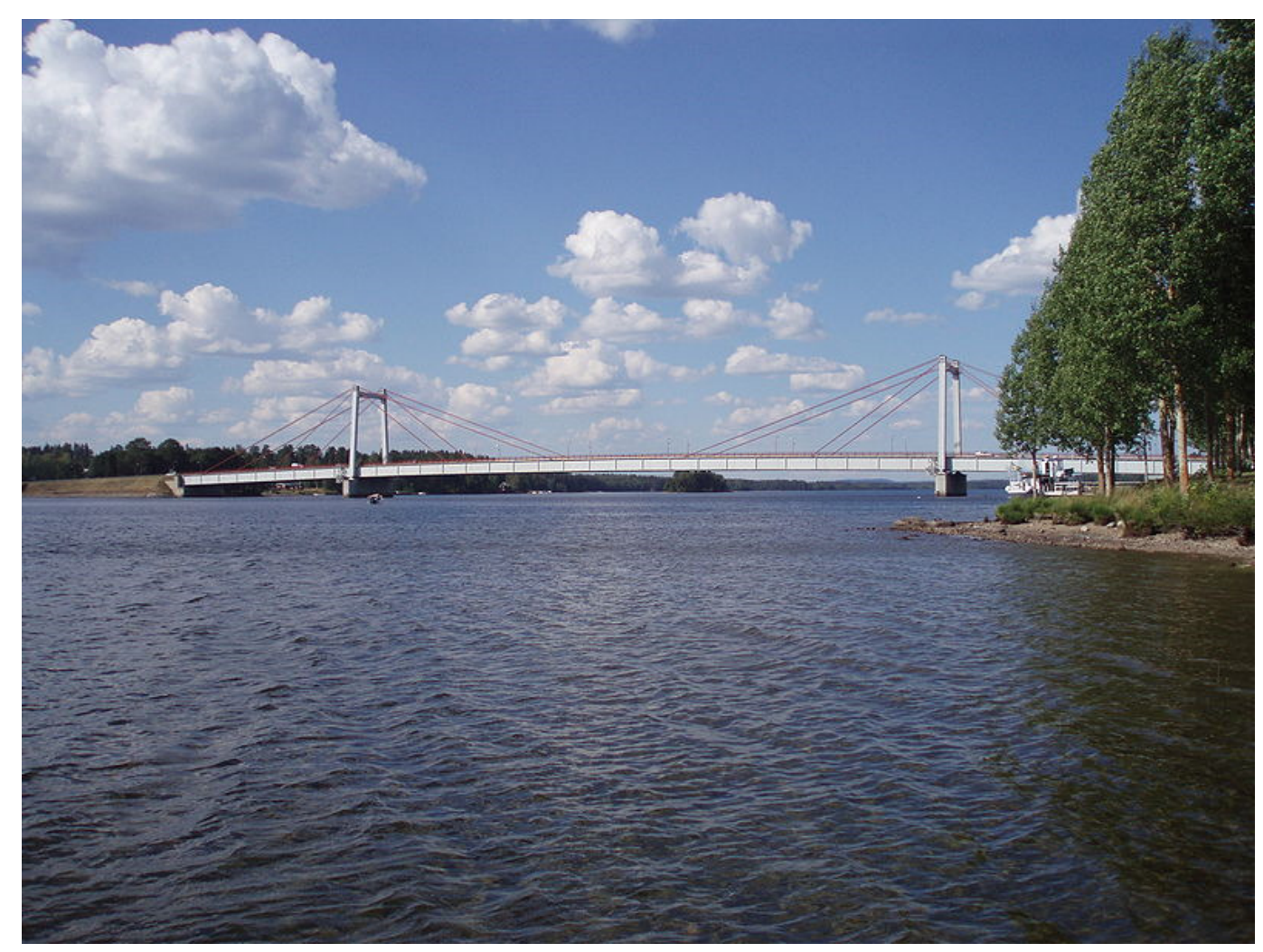

Figura 1.9 - Ponte de Strömsund, na Suécia

(http://en.wikipedia.org/wiki/File:Str\%C3\%B6msundsbron2.jpg)

Esta ponte é considerada por alguns autores a primeira ponte estaiada moderna, mesmo possuindo alguns indícios das pontes construídas anteriormente, tal como o grande espaçamento dos pontos de fixação dos estais no tabuleiro, e de ter sido concluída após a ponte de Donzère-Mondragon. 


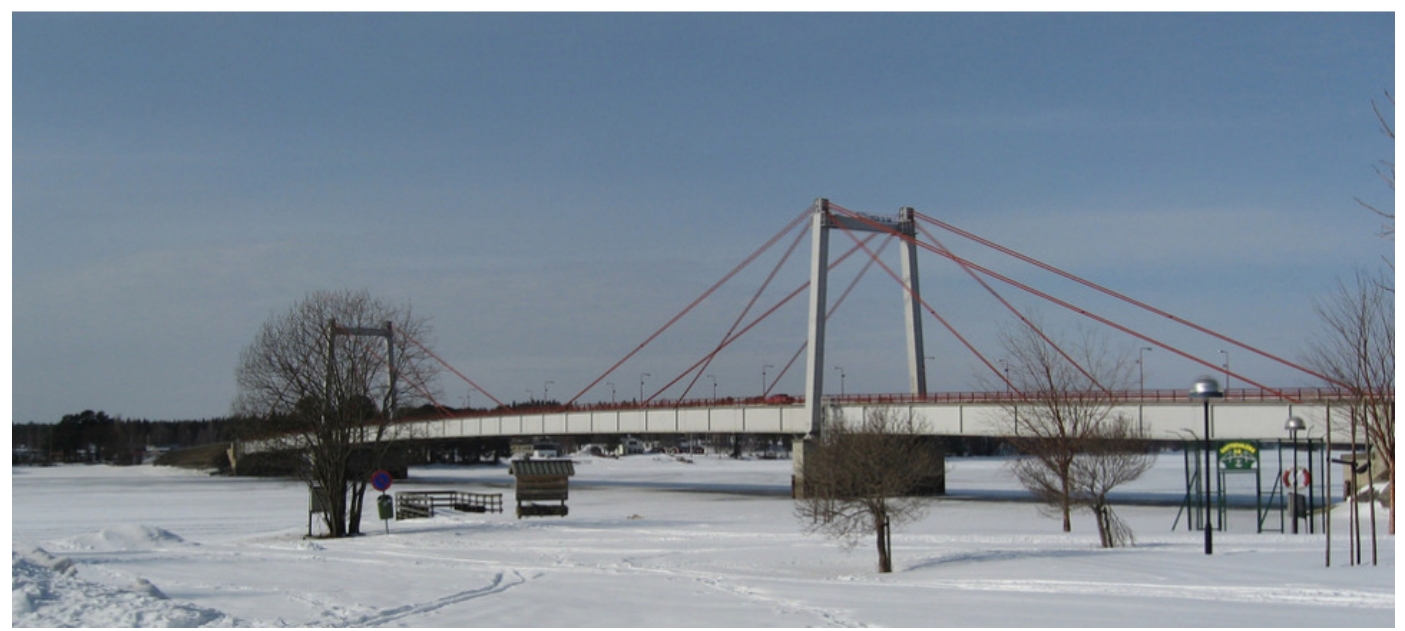

Figura 1.10 - Ponte de Strömsund, na Suécia (http://www.flickr.com/photos/ylvas/433342208)

Além da ponte de Stromsund, a ponte de Donzère-Mondragon, que atravessa o canal de Donzére na França, também é considerada uma das primeiras pontes estaiadas modernas. Esta ponte, que atravessa o canal de Donzère, na França, é uma estrutura mista de concreto e aço, e teve sua construção finalizada em 1952, vencendo um vão de $81,0 \mathrm{~m}$.

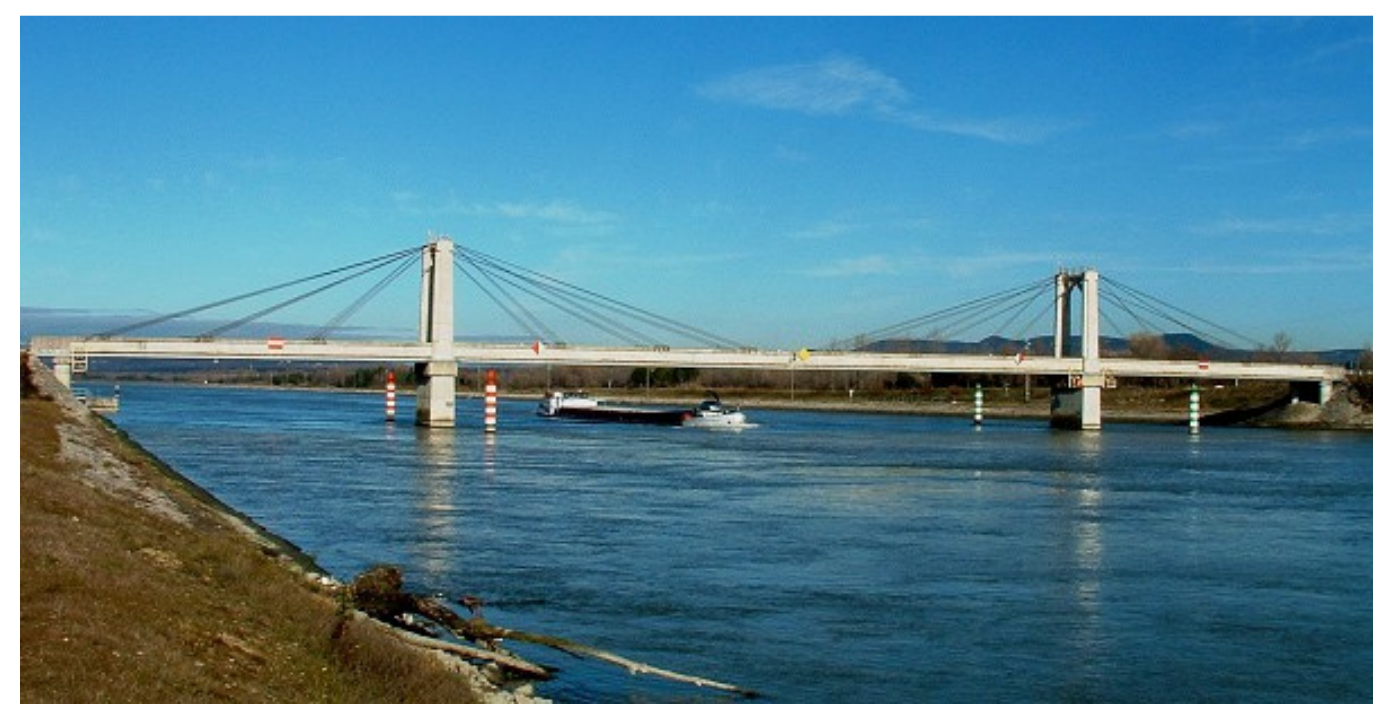

Figura 1.11 - Ponte Donzère-Mondragon, na França (http://en.structurae.de/photos/index.cfm?JS=32221)

Outro fator que impulsionou o crescimento das pontes estaiadas foi a facilidade com que a mesma se adaptou às necessidades da época. Com o fim da Segunda Guerra Mundial, o rastro da destruição era visto por toda a Europa, onde estradas, cidades e pontes necessitavam ser reconstruídas. Como tudo havia de ser 
reconstruído em pouco tempo, devido à necessidade de reintegração entre as cidades que ficaram isoladas, a utilização de métodos construtivos que possibilitassem um ritmo mais acelerado ganhou destaque.

Com isso, as pontes estaiadas ganharam definitivamente o seu espaço e começaram a ser amplamente utilizadas, uma vez que a maioria das pontes destruídas mantinha sua infra-estrutura em condições de uso. Sendo assim, engenheiros e construtores necessitavam de pontes mais leves, mas que tivessem rigidez suficiente para vencer o vão necessário, além de permitir o trafego de veículos mais pesados que os utilizados anteriormente.

Com o avanço dos métodos de cálculo e verificação das estruturas, juntamente com a experiência já obtida com os erros do passado, as pontes estaiadas se disseminaram nos anos seguintes, principalmente pela Europa e América do Norte.

Fritz Leonhardt, um dos grandes pesquisadores da época, contribuiu de maneira significativa neste contexto, provando que a utilização de formas aerodinâmicas é muito mais vantajosa do que a utilização de seções com elevada rigidez, uma vez que contribui para a redução do peso da estrutura e atinge o mesmo objetivo. Com isso, praticamente todas as pontes estaiadas e pênseis construídas após 1952, data dos estudos aerodinâmicos de Leonhardt, foram concebidas desta maneira, utilizando seções aerodinâmicas para o tabuleiro.

Algumas pontes estaiadas projetadas e executadas neste período merecem destaque pela inovação, sendo elas: 


\section{Ponte Theodor Heuss:}

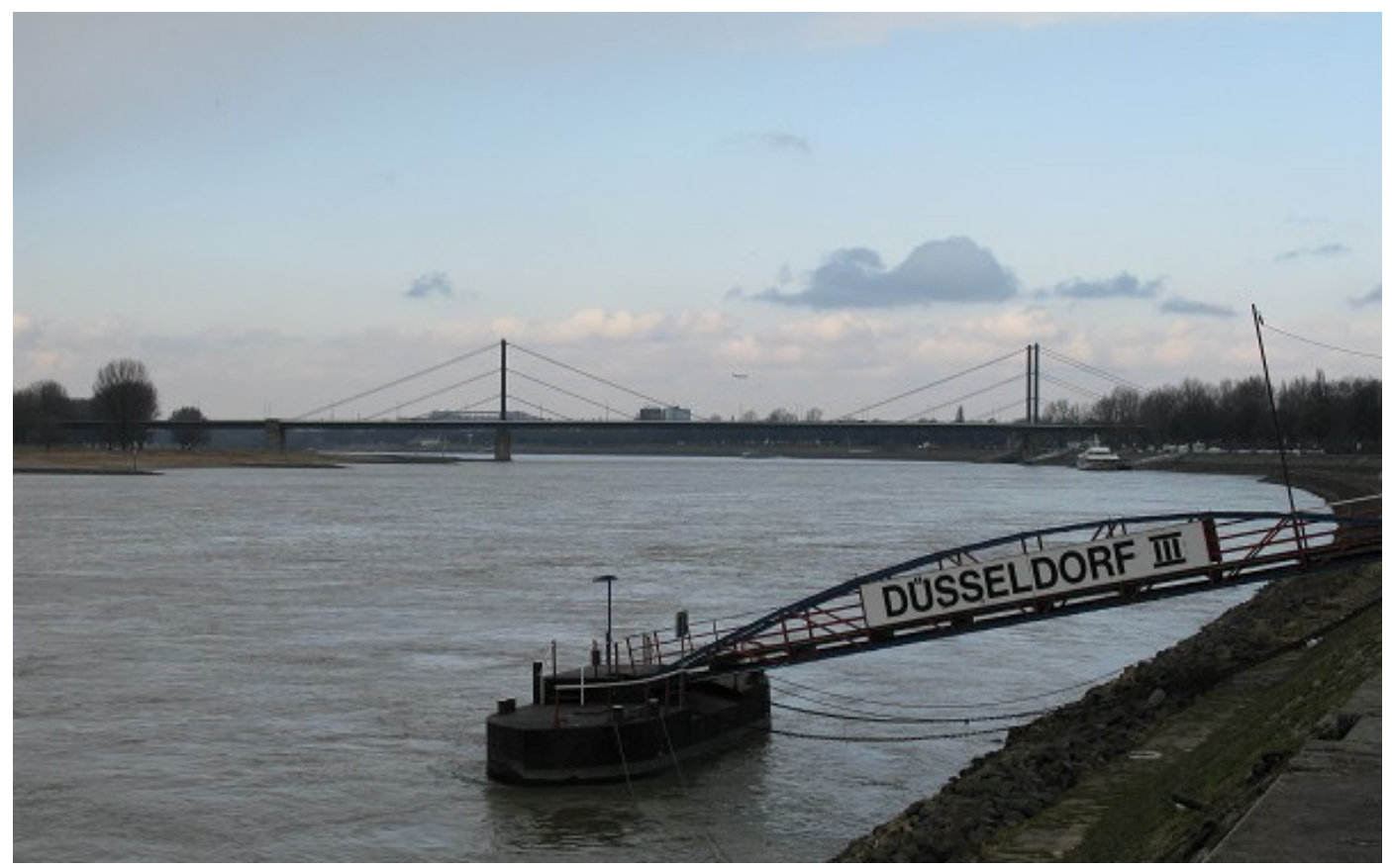

Figura 1.12 - Ponte de Theodor Heuss, na Alemanha (http://en.structurae.de/photos/index.cfm?JS=161795)

A ponte Theodor Heuss foi projetada pelos engenheiros Erwin Beyer e Louis Wintergerst, em parceria com o arquiteto Friedrich Tamms e com a consultoria de Fritz Leonhardt.

Esta ponte possui um tabuleiro metálico de 3,39 m de espessura e 26,6 m de largura, com $476 \mathrm{~m}$ de extensão e vão principal de $260 \mathrm{~m}$. Os mastros metálicos desta ponte possuem 43,91 m de altura. Sua construção ocorreu no período de 1953 a 1957. Após essa data, a ponte passou por pequenas manutenções, mas continua aberta ao trafego. 


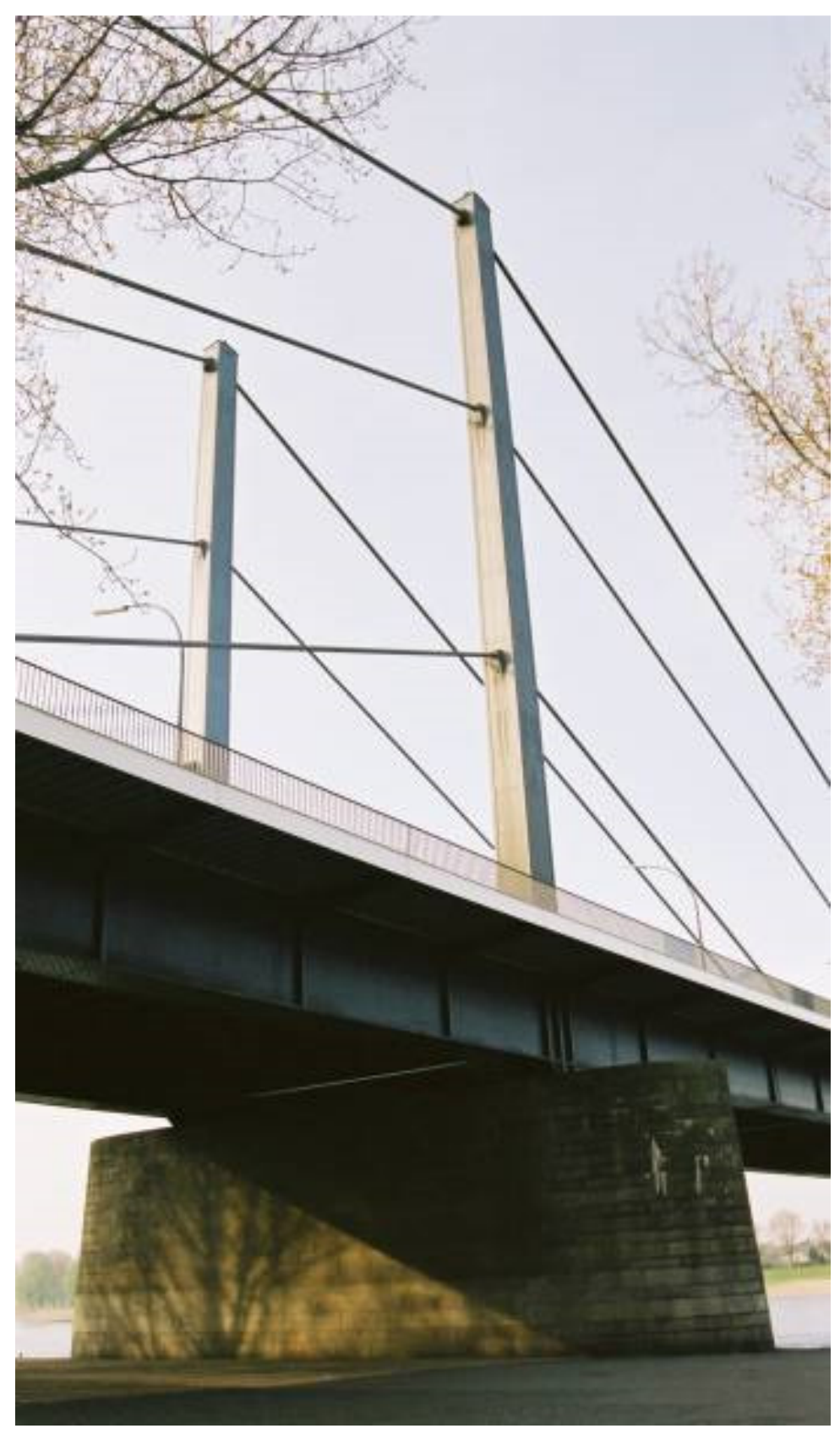

Figura 1.13 - Ponte de Theodor Heuss, na Alemanha (http://en.structurae.de/photos/index.cfm?JS=8422) 


\section{Ponte Knee (Kniebrücke):}

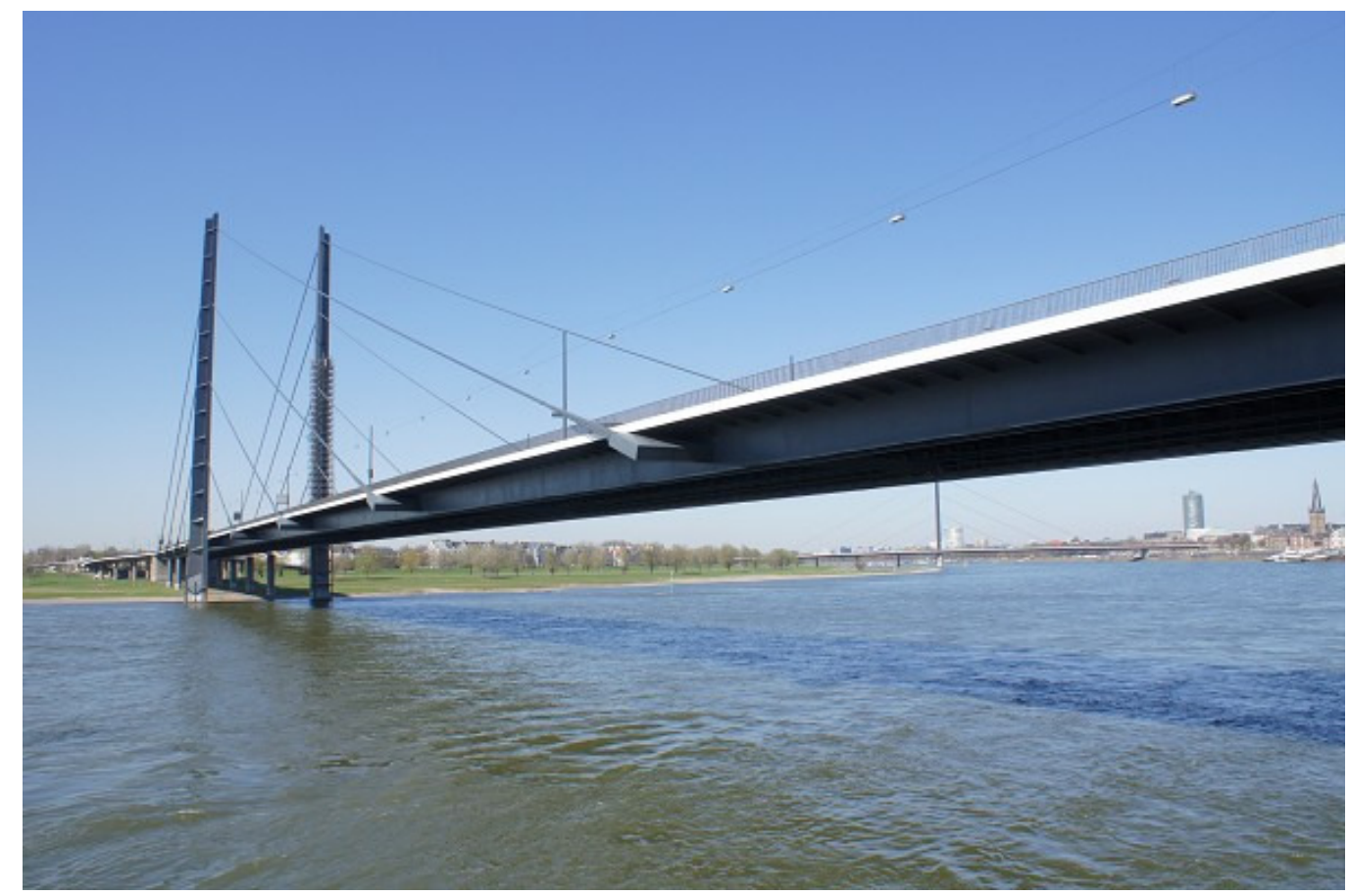

Figura 1.14 - Ponte Knee, na Alemanha (http://en.structurae.de/photos/index.cfm?JS=171997)

A ponte Knee foi projetada pelos engenheiros Erwin Beyer e Fritz Leonhardt, em parceria com o arquiteto Friedrich Tamms.

Projetada inteiramente em estrutura metálica, com exceção da fundação, a ponte Knee foi construída de 1965 a 1969, atravessando o rio Reno na Alemanha. Esta ponte possui um tabuleiro com 28,92 $\mathrm{m}$ de largura e $3,35 \mathrm{~m}$ de altura, totalizando um comprimento de $561,15 \mathrm{~m}$ e vão principal de $319 \mathrm{~m}$. Os mastros metálicos possuem uma altura 114,1 m.

A ponte Knee foi umas das primeiras pontes em que se adotou uma geometria assimétrica, onde os esforços provenientes do vão principal são conduzidos até estruturas de ancoragem, conforme mostrado a seguir (Figura 1.15). 


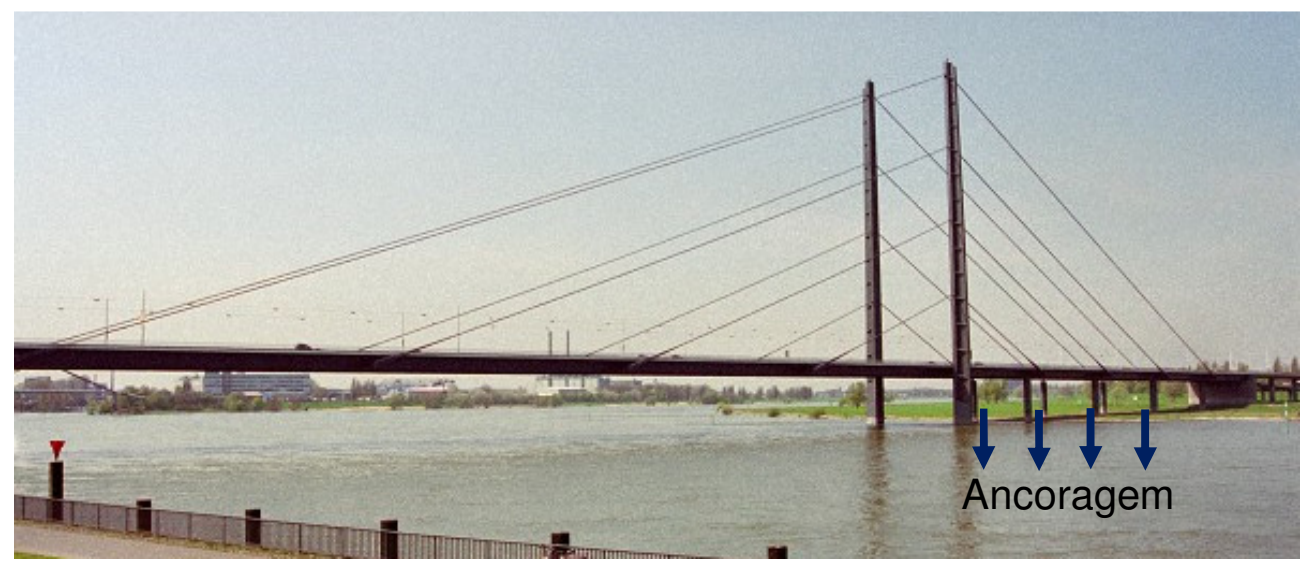

Figura 1.15 - Ancoragem dos estais (http://en.structurae.de/photos/index.cfm?JS=58413)

\section{Ponte Oberkassel:}

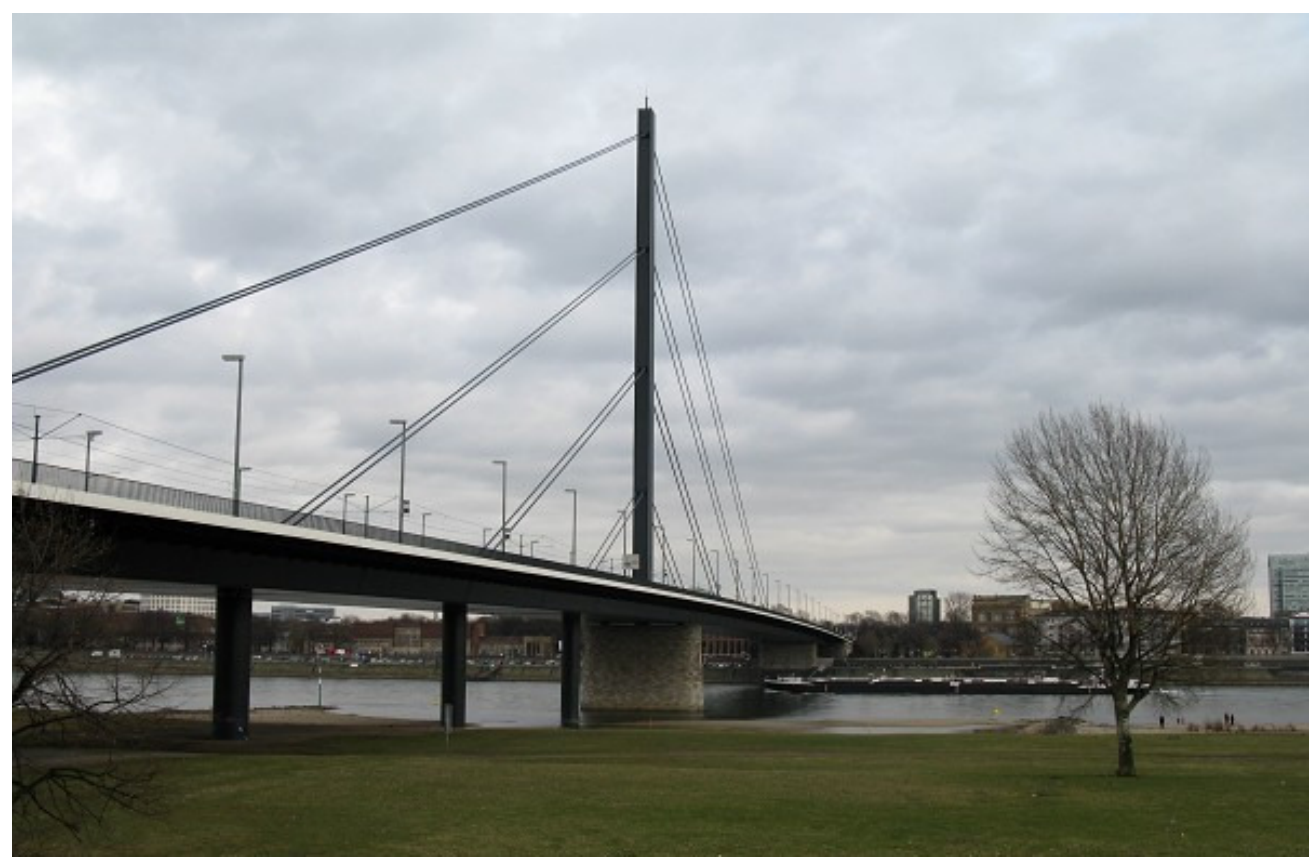

Figura 1.16 - Ponte Oberkassel, na Alemanha. (http://en.structurae.de/photos/index.cfm?JS=163977)

A ponte Oberkassel foi projetada pelos engenheiros Erwin Beyer e Louis Wintergerst, em parceria com o arquiteto Friedrich Tamms e com a consultoria de Fritz Leonhardt. Sua construção teve como finalidade a substituição da antiga ponte Oberkassel (figura 1.17), que foi construída de 1925 a 1926. Esta ponte era uma estrutura metálica em arco com o tabuleiro suspenso e pilares em alvenaria de pedra. 


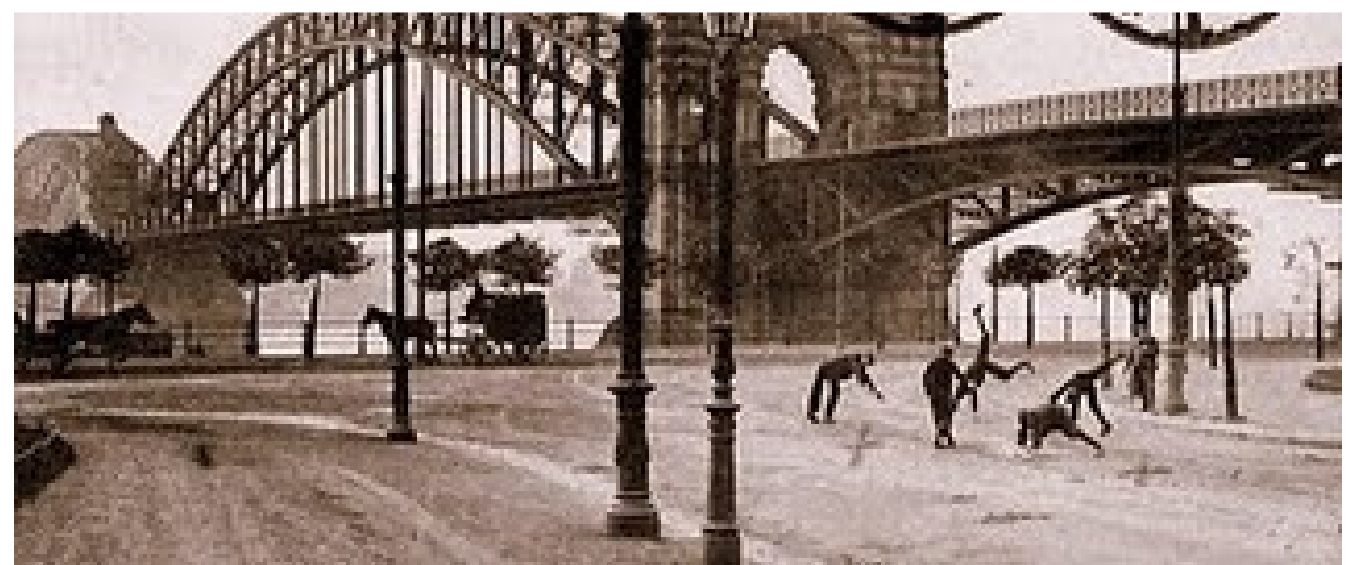

Figura 1.17 - Antiga Ponte Oberkassel

(Analoog Sixty - Erwin Janssen Ruys - http://analoog60.blogspot.com)

A nova ponte Oberkassel, que atravessa o rio Reno na Alemanha, possui um tabuleiro metálico com $35 \mathrm{~m}$ de largura, 3,15 m de espessura e um vão principal de 257,75 m. O mastro metálico possui uma altura de 103,15 m. Sua construção ocorreu no período de 1969 a 1973, mas só foi aberta livremente ao tráfego em 30 de abril de 1976.

\section{Ponte Maracaibo:}

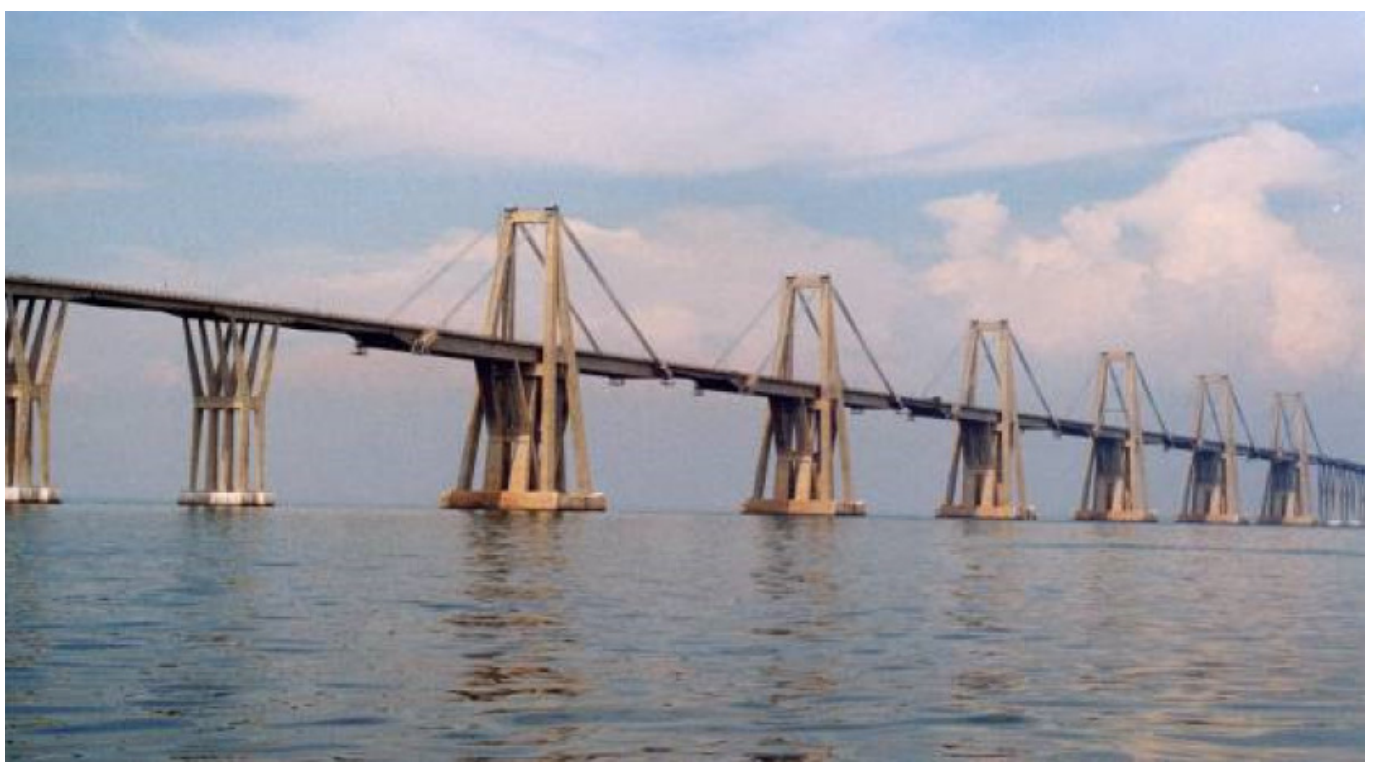

Figura 1.18 - Ponte Maracaibo, na Venezuela (http://en.structurae.de/photos/index.cfm?JS=13575)

A ponte Maracaibo, também conhecida por ponte General Rafael Urdaneta, projetada pelo arquiteto e engenheiro Riccardo Morandi, com a consultoria 
geotécnica de Jean Kérisel, acabou se tornando sua obra mais famosa, ganhando reconhecimento internacional.

Construída de 1958 a 1962 na Venezuela, a ponte Maracaibo possui 8,7 km de extensão e cinco vãos principais de $235 \mathrm{~m}$. O tabuleiro de concreto protendido possui $17,4 \mathrm{~m}$ de largura e $5,0 \mathrm{~m}$ de espessura. Os pilares também de concreto protendido possuem uma altura de $86,6 \mathrm{~m}$.

Esta obra foi pioneira para as pontes estaiadas de múltiplos vãos, onde se repete uma mesma solução estrutural o número de vezes que for necessário.

A ponte Maracaibo é constituída basicamente por três soluções estruturais distintas. Primeiramente existem os trechos de aproximação aos vãos centrais, sendo estes executados com tabuleiros de concreto protendido, de vãos variando de $22,6 \mathrm{~m}$ a 85,0 m. Para transpor os vãos principais de $235 \mathrm{~m}$ de extensão, repetidos cinco vezes, foi adotada a solução de ponte estaiada. Por fim, para fazer a ligação entre os trechos estaiados, foram utilizados tabuleiros bi-apoiados isostáticos.

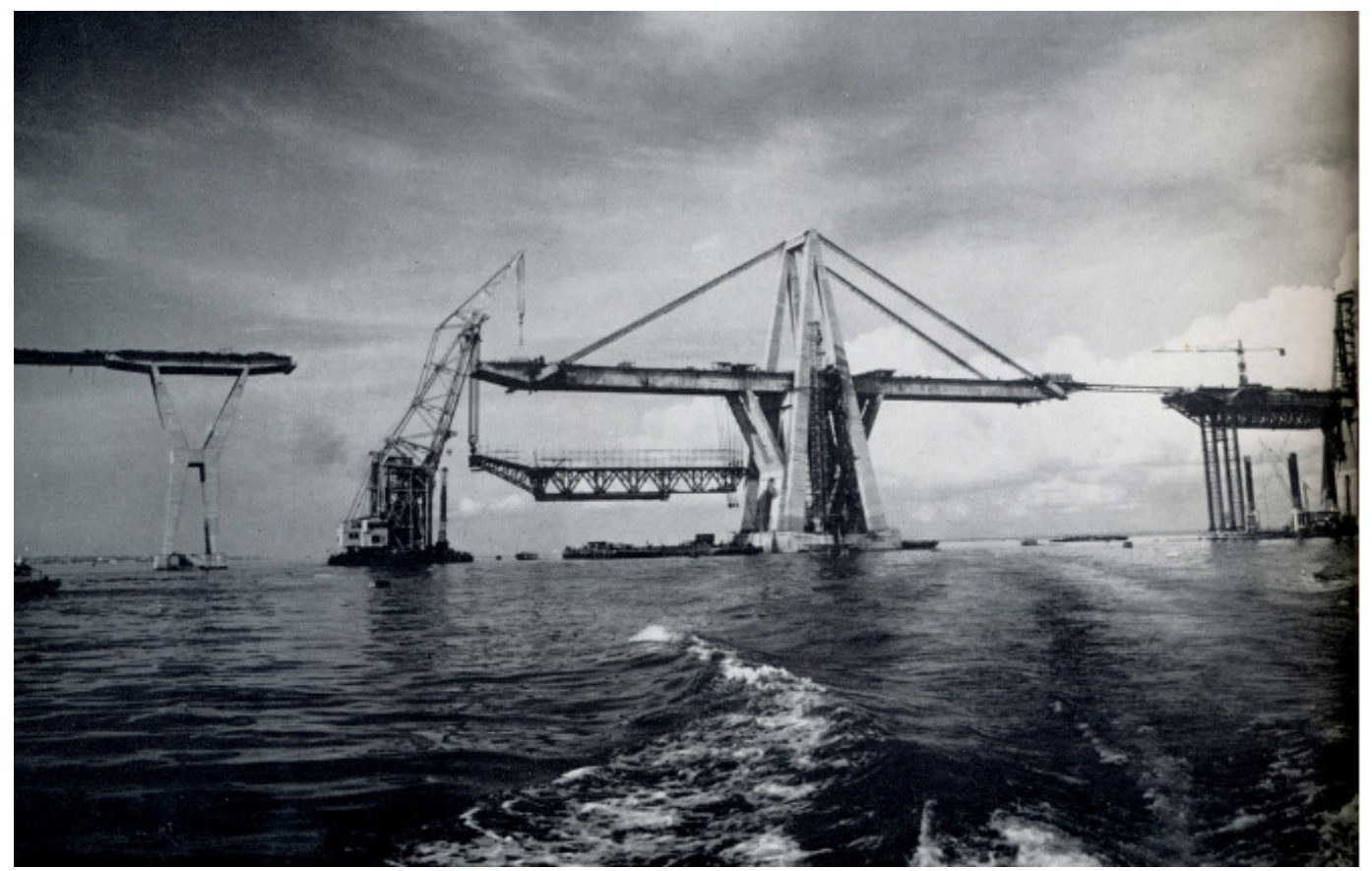

Figura 1.19 - Construção da Ponte Maracaibo

(Theater of Memory - http://theartofmemory.blogspot.com)

Nesta estrutura nota-se que os pontos de fixação dos estais estão muito afastados dos mastros, sendo esta distância por volta de $85 \mathrm{~m}$. Tendo em vista esse fato houve a necessidade da execução de um tabuleiro robusto, a fim de resistir aos 
elevados esforços de flexão longitudinal atuantes na estrutura. Além disso, houve a necessidade da execução de pilares temporários para apoiar o tabuleiro até que a instalação dos estais estivesse finalizada, conforme se pode ver na figura 1.20.

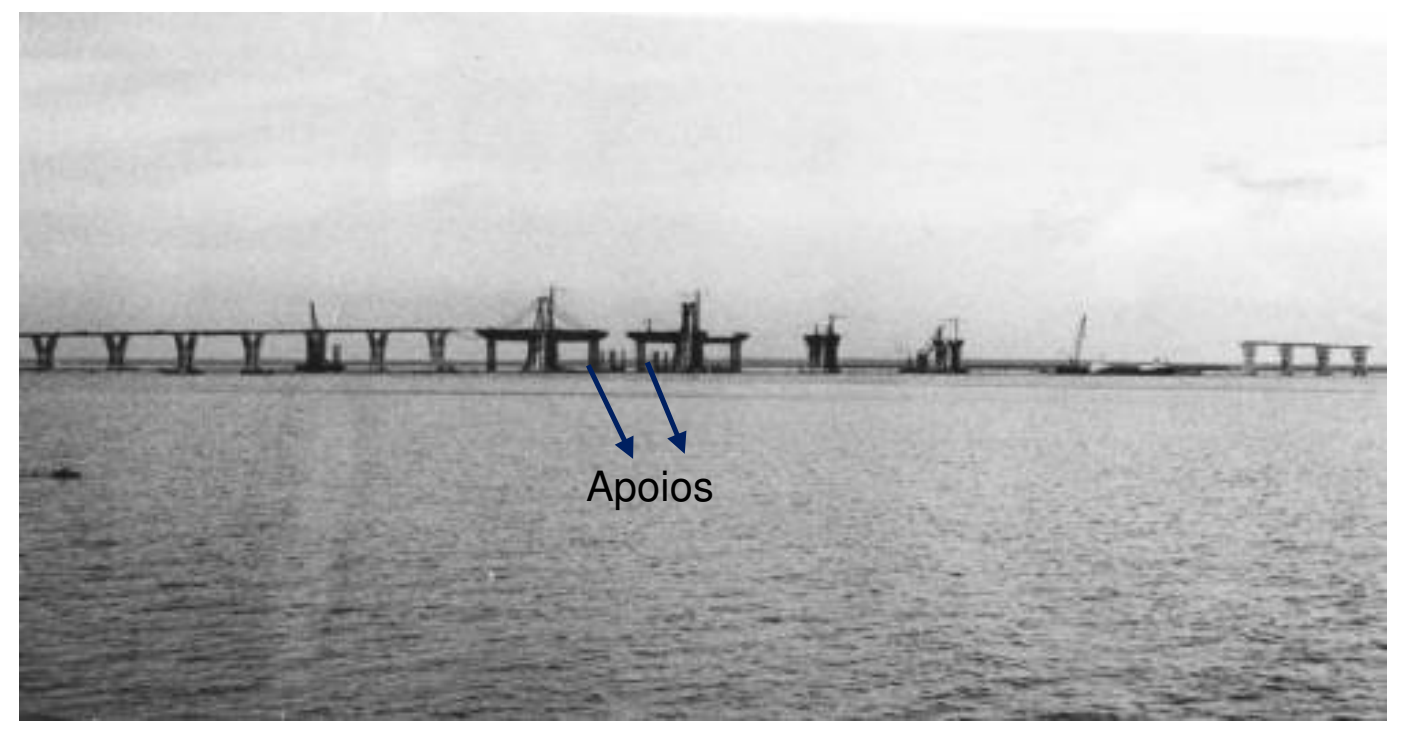

Figura 1.20- Construção da Ponte Maracaibo (http://www.venezuelatuya.com)

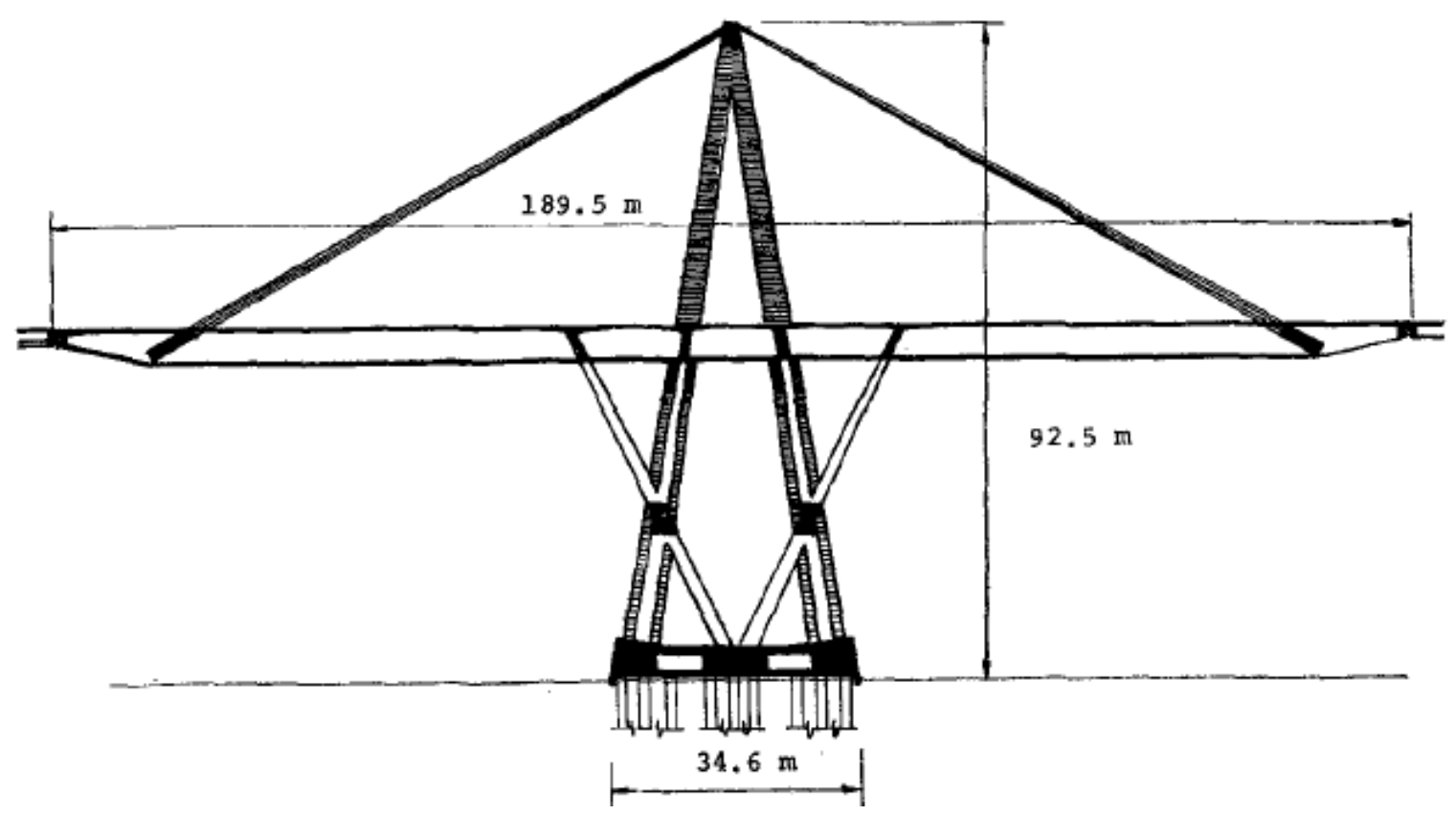

Figura 1.21 - Corte longitudinal da Ponte Maracaibo (Walter Podolny, Jr.) 


\section{Ponte Wadi-Kuf:}

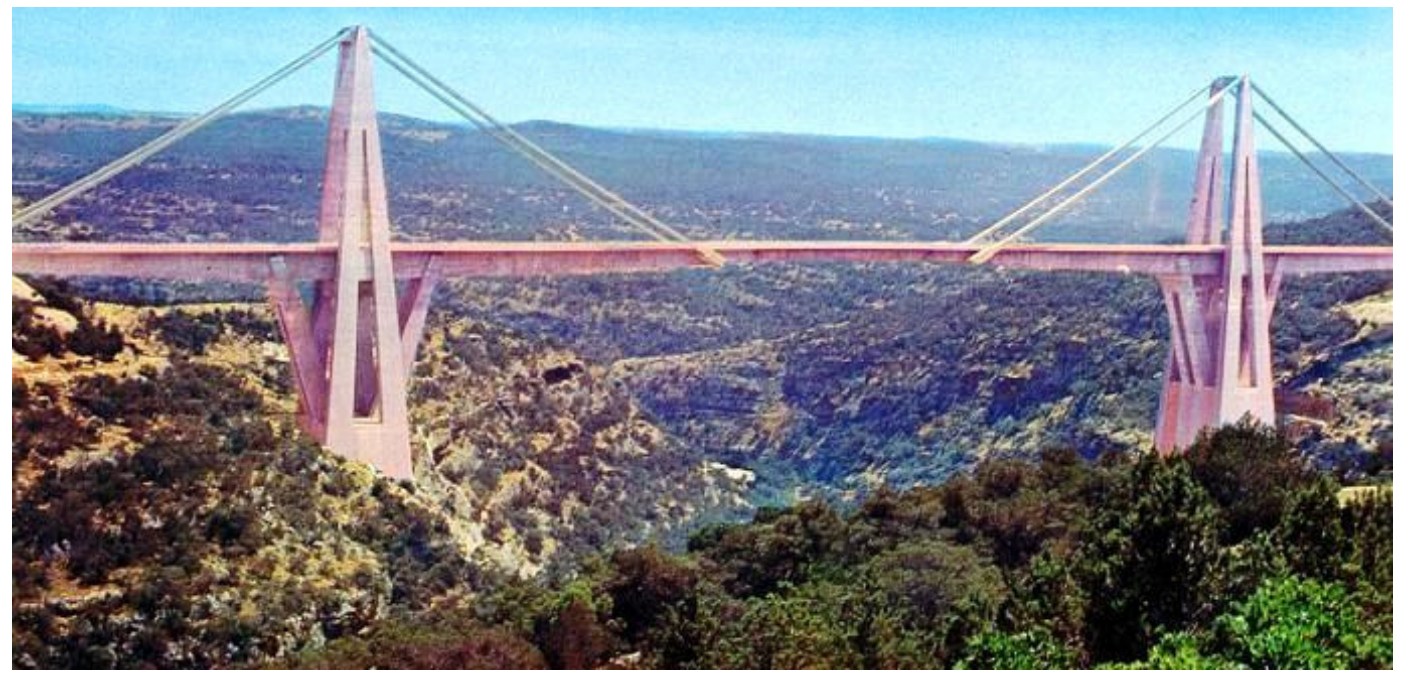

Figura 1.22 - Ponte Wadi-Kuf, na Libia.

(http://en.wikipedia.org/wiki/File:Wadi_el_Kuf_Bridge_1970\%27s.jpg)

Também projetada pelo arquiteto e engenheiro Riccardo Morandi, a ponte Wadi-Kuf se destaca pelo grande espaçamento dos estais que sustentam o tabuleiro. Assim como na ponte Maracaibo, o tabuleiro é suficientemente robusto para que possa resistir aos esforços de flexão longitudinal, uma vez que a quantidade de apoios é pequena. Os pilares em $\mathrm{W}$ também são peças robustas e de grandes dimensões, contribuindo de maneira significativa para a estabilidade do tabuleiro..

Construída entre 1965 e 1971, a ponte possui 447 m de extensão, tendo o vão central de $282 \mathrm{~m}$, que está localizado $160 \mathrm{~m}$ acima do terreno. O tabuleiro em concreto protendido possui uma largura 13,3 $\mathrm{m}$.

No centro do vão principal também foi utilizado um tabuleiro biapoiado isostático, apoiando se nos extremos dos trechos estaiados.

Para a execução do tabuleiro que partem dos pilares, foi necessária a utilização de estais temporários até que se atingisse o ponto onde os estais principais seria executados, uma vez que a execução de pilares provisórios, como foi feito na ponte Maracaibo, seria economicamente inviável, uma vez que a altura do solo até a ponte é considerável. 


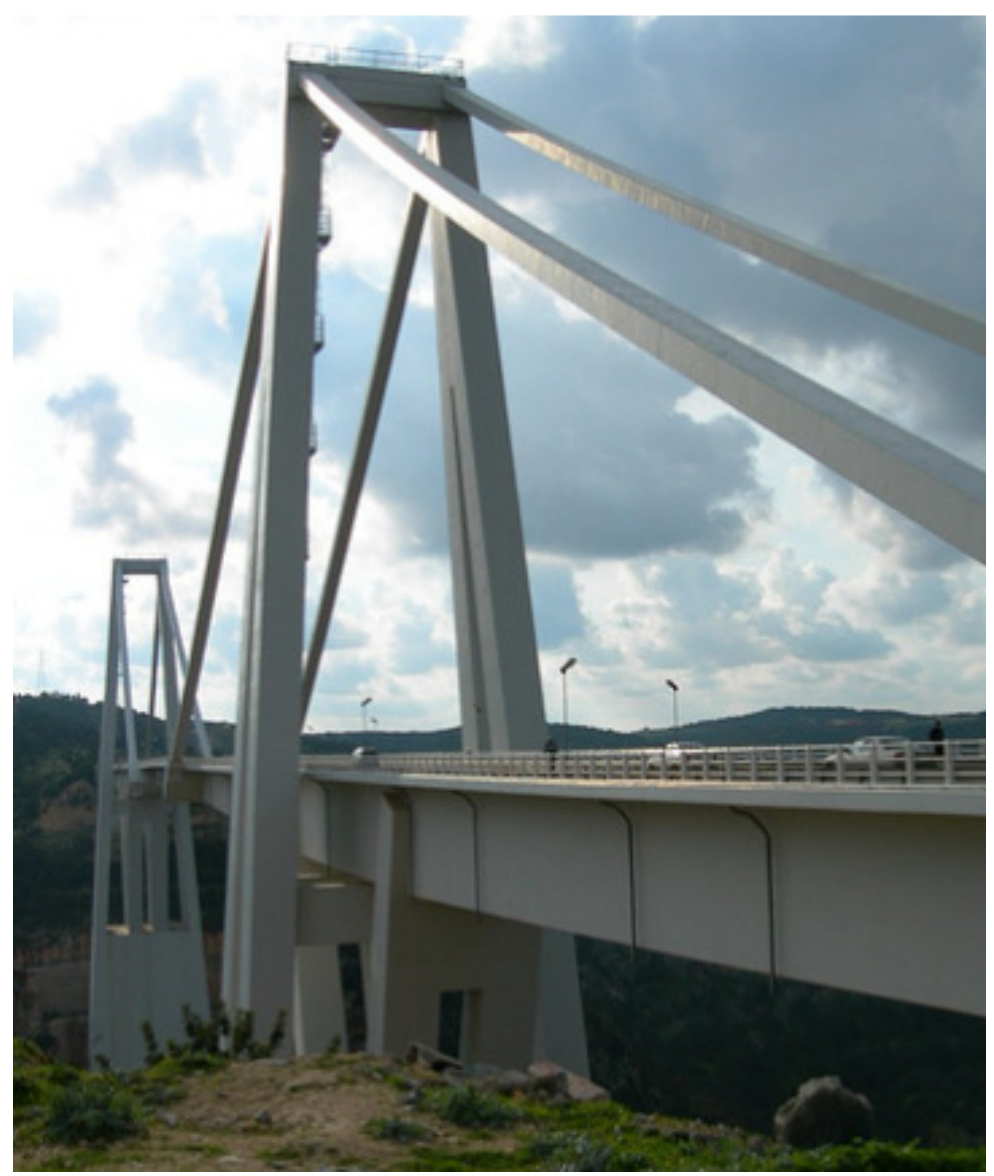

Figura 1.23 - Ponte Wadi-Kuf, na Libia. (http://www.flickr.com/photos/simon_p_white/374668697)

\section{Ponte Friedrich Ebert:}

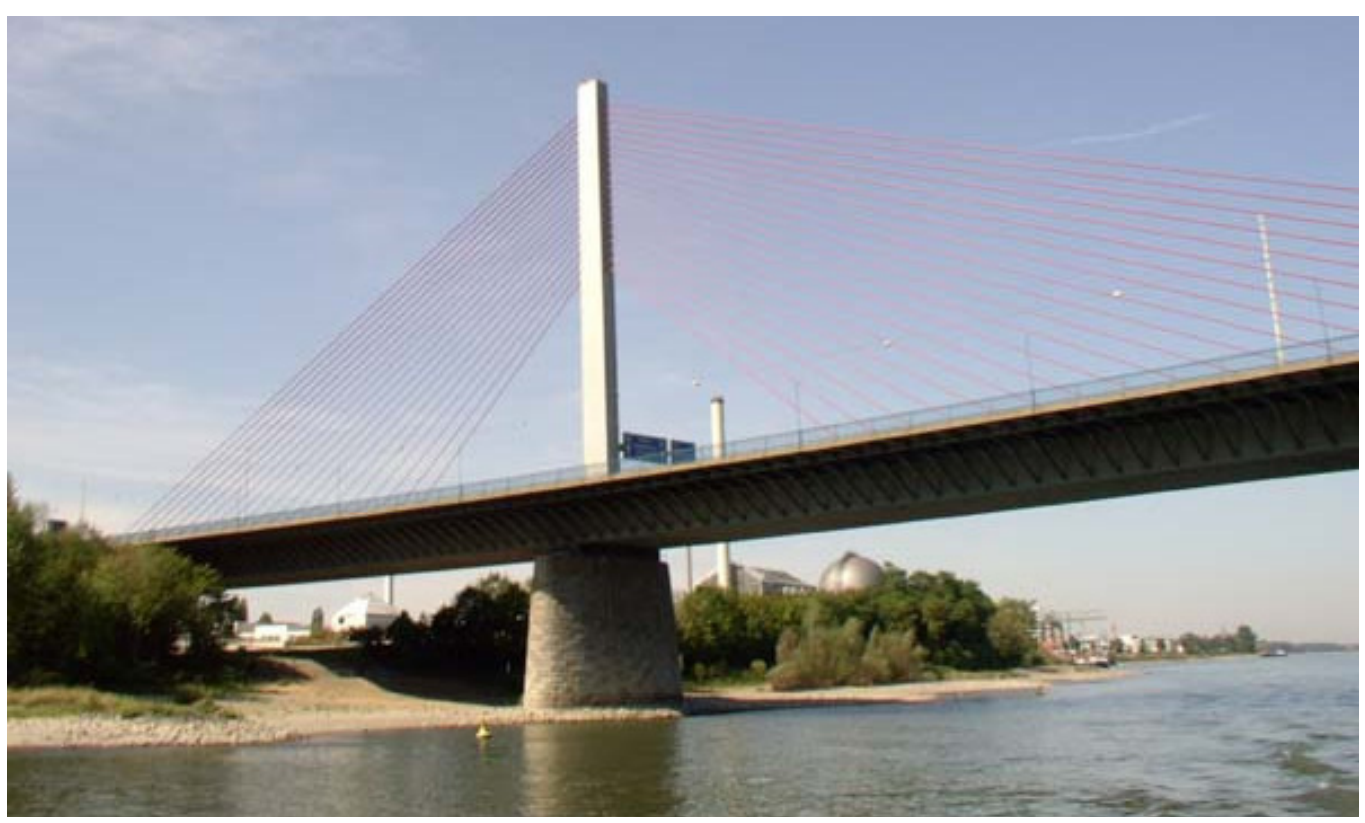

Figura 1.24 - Ponte Friedrich Ebert, na Alemanha (http://en.structurae.de/photos/index.cfm?JS=12440) 
A Ponte Friedrich Ebert, projetada por Hellmut Homberg e construída entre 1964 e 1967, foi a primeira ponte a utilizar múltiplos estais em um único plano.

Outra inovação presente nesta ponte é a elevada quantidade de estais, assim como a proximidade com que os mesmos chegam ao tabuleiro. Esta geometria faz com que a carga suportada por cada cabo seja bem menor que nas pontes onde o espaçamento é maior. Com isso, houve a possibilidade da utilização de estais de menor diâmetro, que propiciaram à ponte um visual mais esbelto e um efeito de transparência aos cabos.

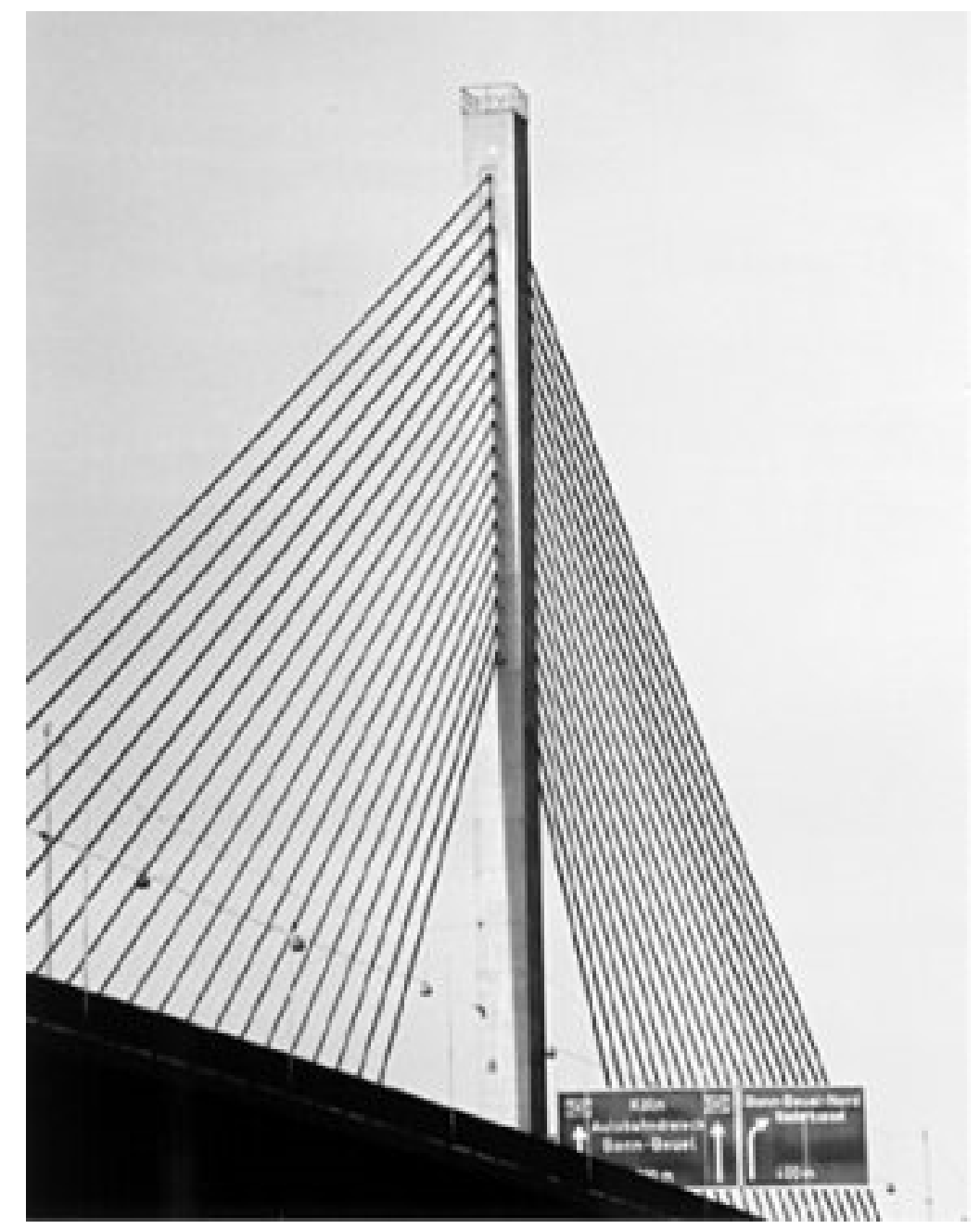

Figura 1.25 - Ponte Friedrich Ebert, na Alemanha (http://en.structurae.de/photos/index.cfm?JS=6)

A ponte possui um comprimento total de $520 \mathrm{~m}$, sendo o vão principal de 280 m. O tabuleiro metálico tem $38,8 \mathrm{~m}$ de largura. Os pilares, também metálicos, possuem $53 \mathrm{~m}$ de altura, acima do tabuleiro. 


\section{Ponte Düsseldorf Flehe:}

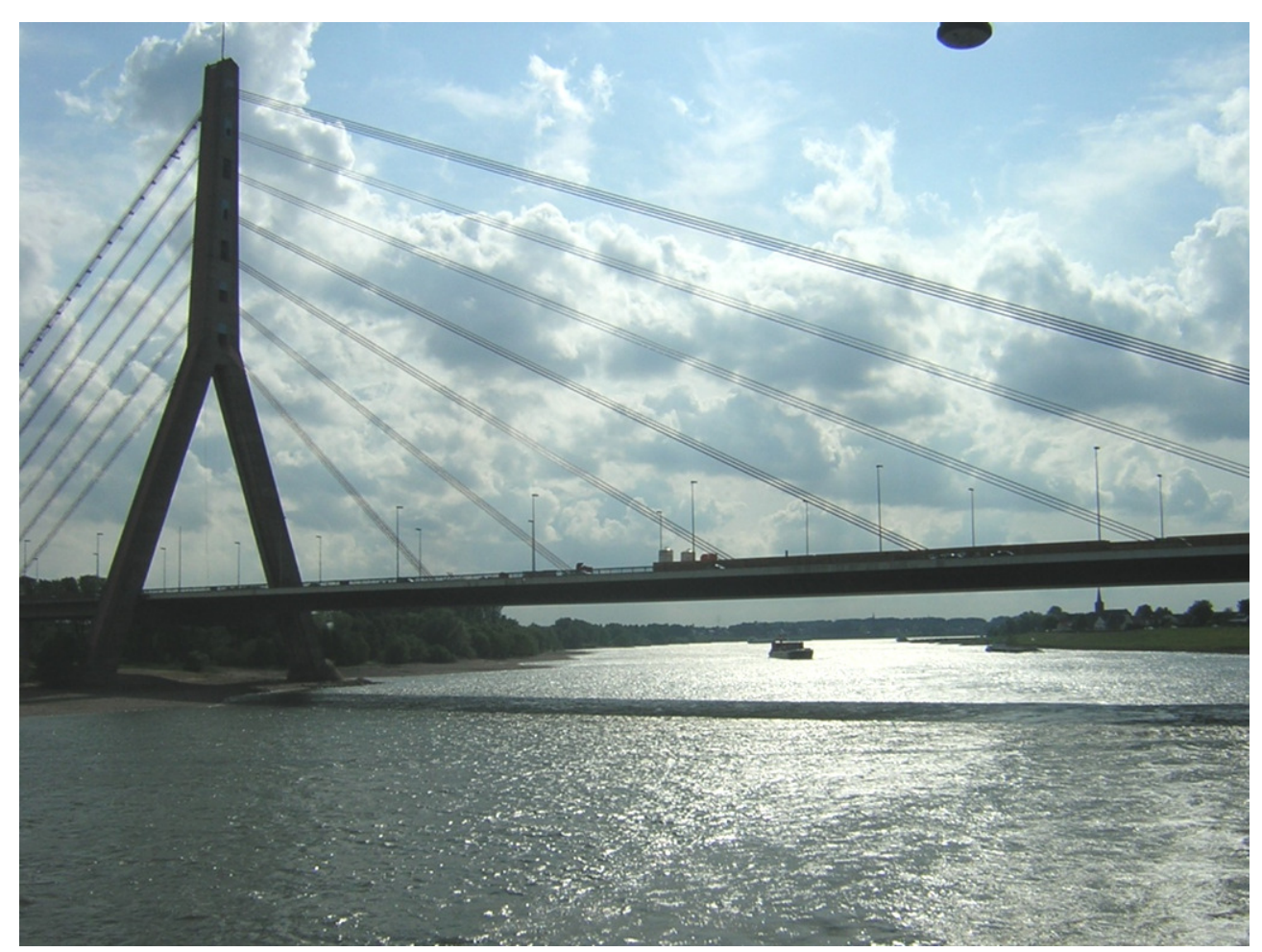

Figura 1.26 - Ponte Düsseldorf Flehe, na Alemanha (http://www.panoramio.com/photo/2316875)

A ponte Düsseldorf Flehe, projetada por R. Kahmann, Fritz Leonhardt e Herbert Schambeck, e com o auxilio do arquiteto Gerd Lohmer, foi construída entre 1976 e 1979, sendo a primeira a utilizar pilares no formato $Y$ invertido, com cabos em um único plano central no formato semi-harpa. 


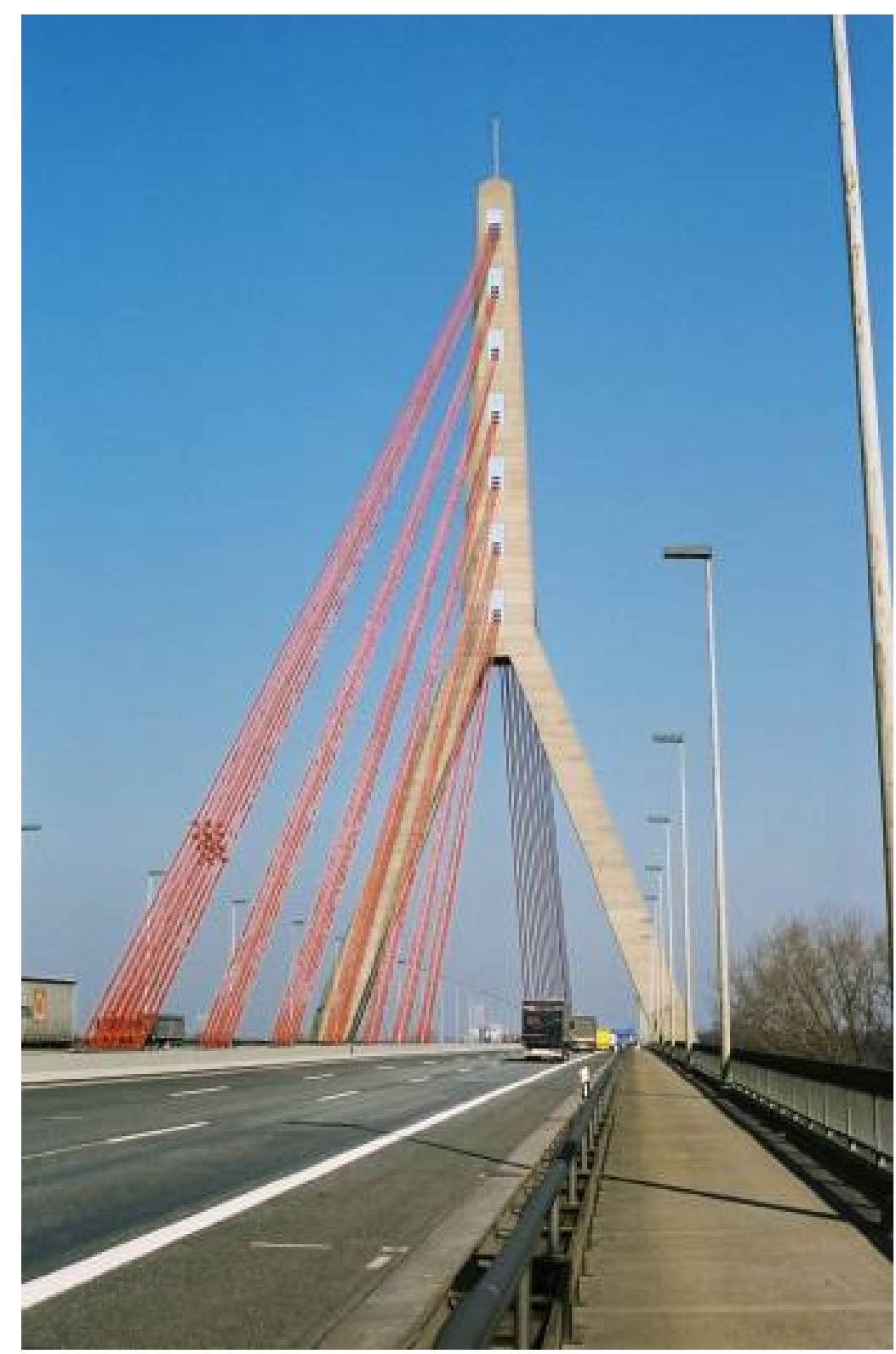

Figura 1.27 - Ponte Düsseldorf Flehe, na Alemanha (http://en.structurae.de/photos/index.cfm?JS=7697)

O tabuleiro principal da ponte é metálico, e possui $41,7 \mathrm{~m}$ de largura. Os tabuleiros de aproximação são em concreto protendido. O mastro da ponte foi executado em concreto e possui uma altura de $160 \mathrm{~m}$. 


\section{Ponte Brotonne:}

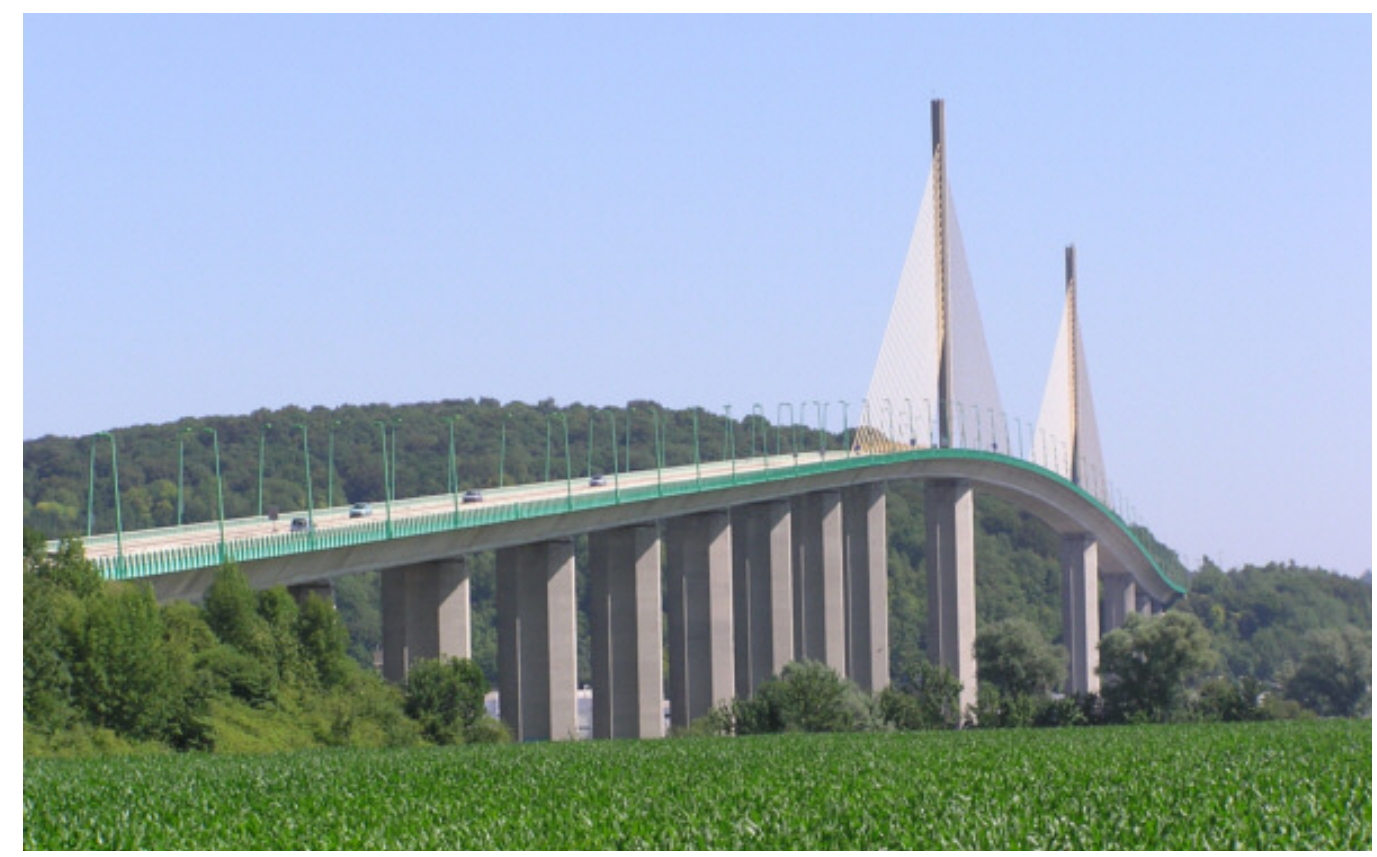

Figura 1.28 - Ponte Brotonne, na França (http://en.structurae.de/photos/index.cfm?JS=67655)

A ponte Brotonne, localizada na França, foi uma das primeiras pontes estaiadas construídas na década de 70. Esta estrutura foi concebida e projetada por Jean Muller, Jacques Combault e Auguste Arsac, possuindo pilares e tabuleiro em concreto, sustentada por estais em um único plano central e geometria de leque. A estrutura possui um comprimento total de $1.278 \mathrm{~m}$ e vão principal de $320 \mathrm{~m}$. O tabuleiro de elementos pré-moldados de concreto protendido possui $19,2 \mathrm{~m}$ de largura e 4,0 m de espessura. 


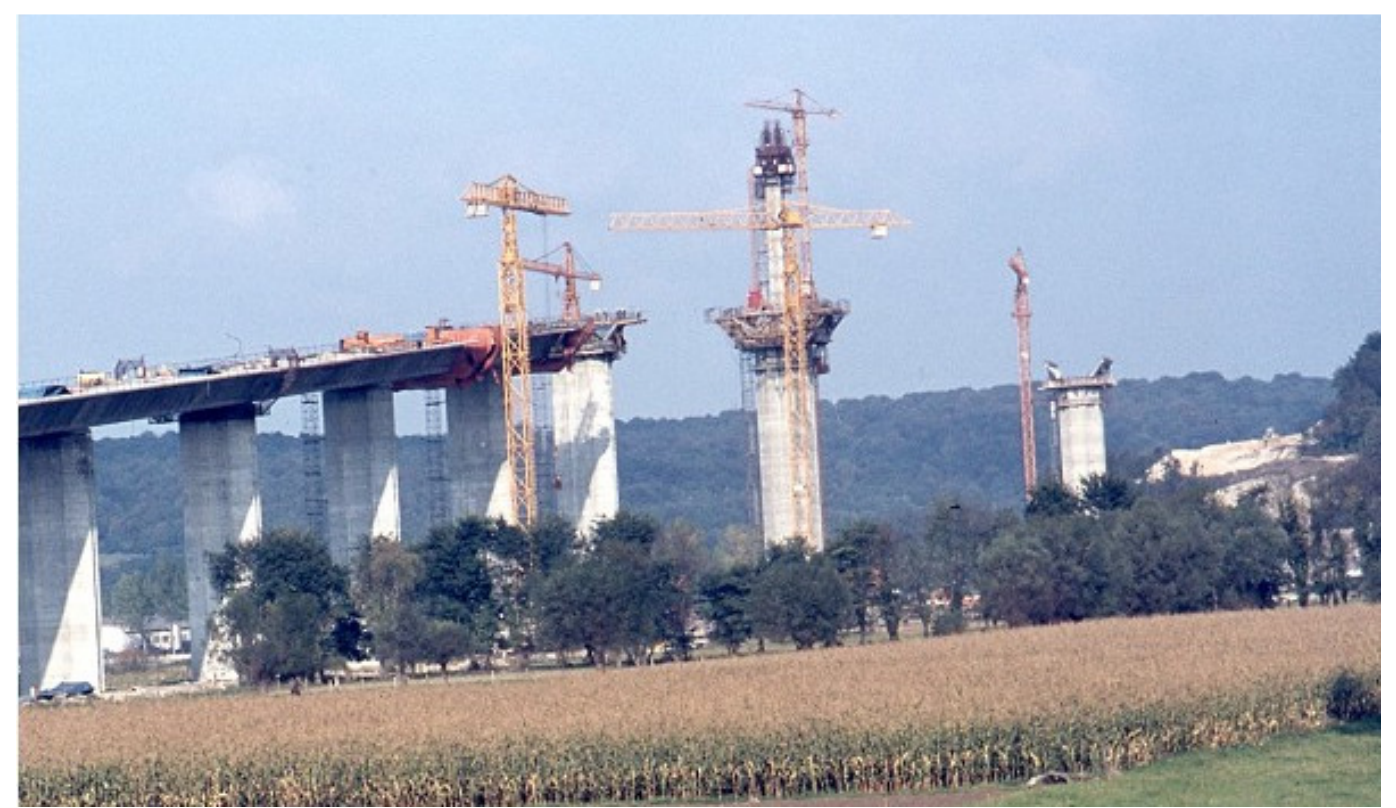

Figura 1.29 - Construção da Ponte Brotonne (http://en.structurae.de/photos/index.cfm?JS=160934)

Nota-se que a partir desta década as pontes estaiadas se apresentam como estruturas mais esbeltas, utilizando de maneira mais racional e consciente as propriedades físicas dos materiais empregados. Muito deste progresso foi possível devido ao avanço dos métodos de dimensionamento destas estruturas, além da experiência adquirida com o grande número de pontes executadas no pós-guerra.

Mesmo assim, durante as décadas de 70 e 80, os vãos atingidos pelas pontes estaiadas no período não avançaram muito além dos $500 \mathrm{~m}$. Quando era necessário transpor um vão maior que este, a solução de ponte pênsil ainda se mostrava mais viável, tanto técnica quanto financeiramente.

Já na década de 90, a realidade foi outra. As pontes estaiadas mostraram um rápido desenvolvimento e os vãos cresceram rapidamente, vencendo todos os recordes obtidos anteriormente, conforme demonstrado no gráfico 1.1. 


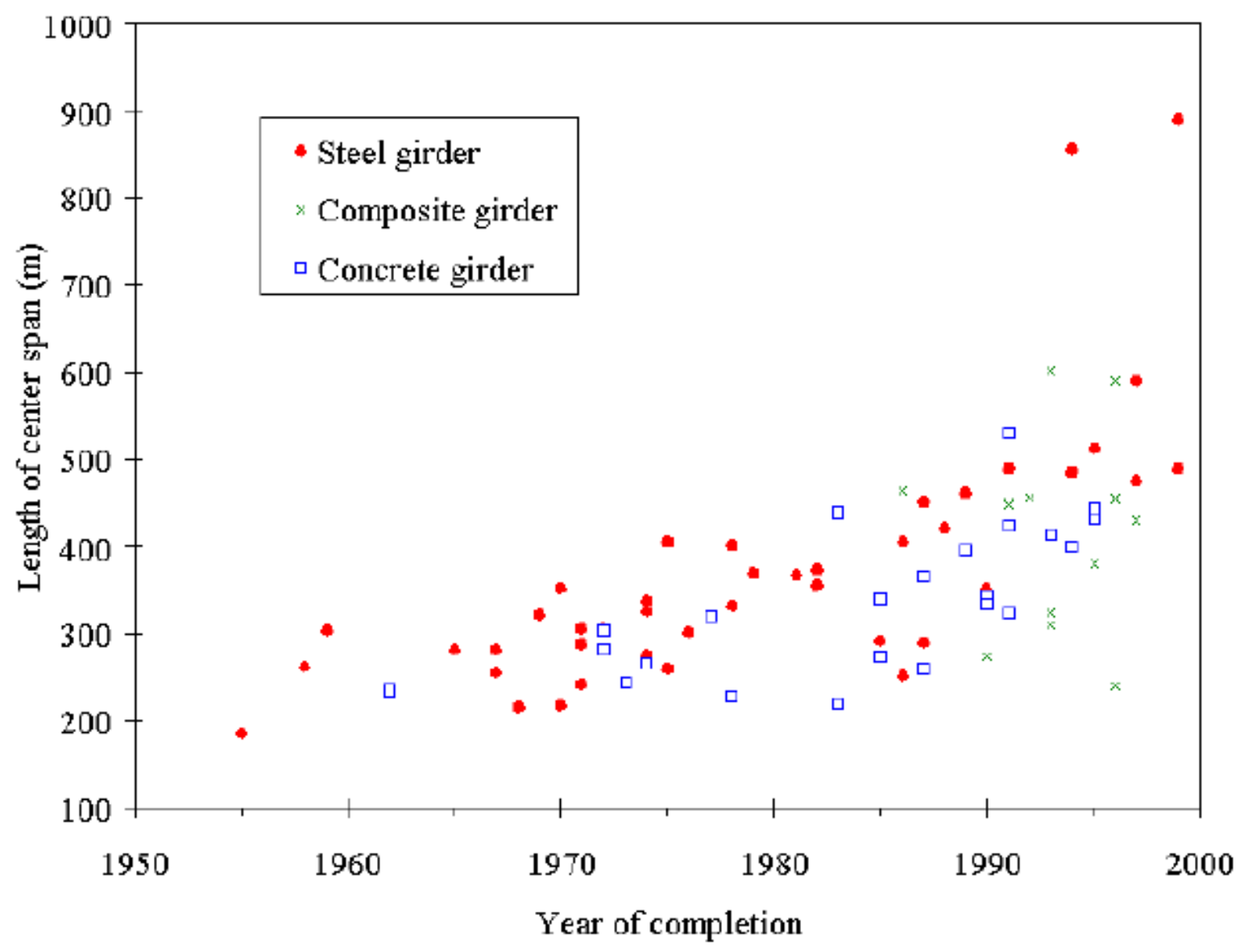

Gráfico 1.1 - Vãos atingidos pelas pontes estaiadas nos últimos 50 anos (KAROUMI, 1998 apud TORNERI, P., 2002)

Como demonstrado neste gráfico, percebe-se que algumas pontes se destacaram a partir da década de 70, atingindo vãos maiores do que $400 \mathrm{~m}$. Mesmo assim, muitas pontes de comprimento reduzido continuaram sendo executadas, tendo em vista que o comprimento das mesmas depende do vão a ser vencido. De qualquer maneira, fica perceptível que, se necessário, pode-se construir uma ponte estaiada com elevada extensão com mais segurança e economia.

A seguir serão apresentadas algumas pontes estaiadas modernas, que se destacam principalmente pela grande extensão dos vãos vencidos, sendo elas: 


\section{Ponte Saint-Nazaire:}

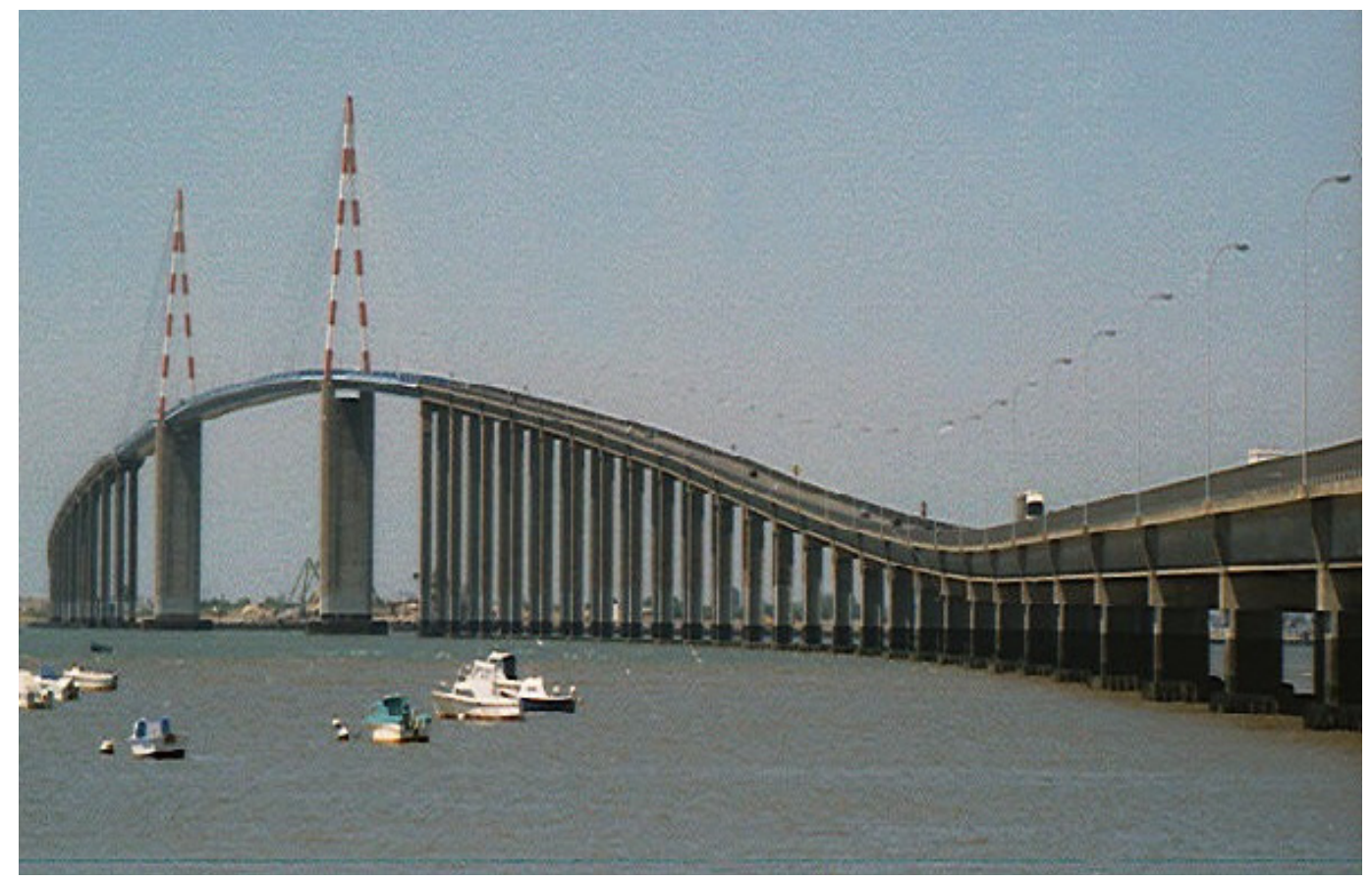

Figura 1.30 - Ponte Saint-Nazaire, na França (http://en.structurae.de/photos/index.cfm?JS=27806)

A ponte Saint-Nazaire foi construída em 1974 sobre o Rio Loire, na França. O comprimento total da ponte é de $720 \mathrm{~m}$, sendo o vão principal estaiado de $404 \mathrm{~m}$. O tabuleiro central foi executado em elementos pré-moldados de concreto protendido (figura 1.31), com uma largura de 15,0 m e 3,2 m de altura. Os mastros metálicos possuem $58,0 \mathrm{~m}$ de altura.

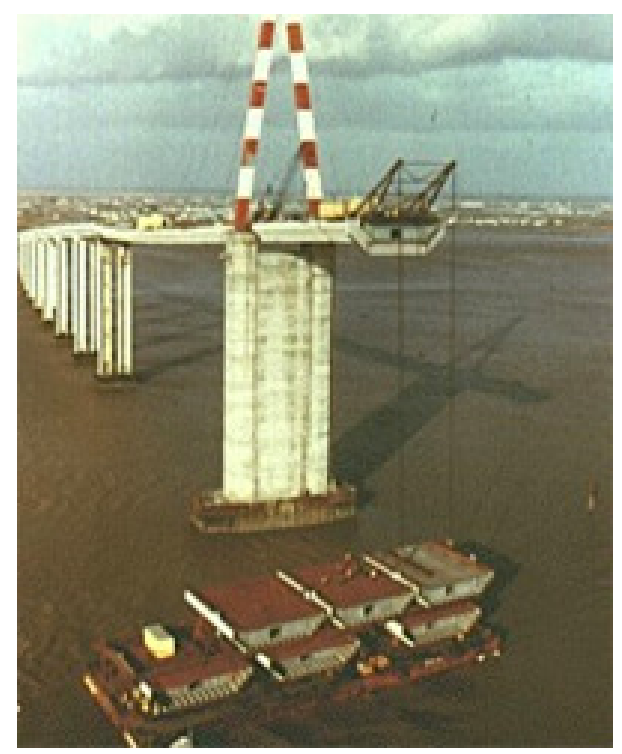

Figura 1.31 - Construção da Ponte Saint-Nazaire (http://www.corusconstruction.com) 
Para a construção do trecho central estaiado, foi utilizado o método das aduelas sucessivas, já para o trecho convencional a construção foi feita utilizando vigas metálicas bi apoiadas.

\section{Ponte Barrios de Luna:}

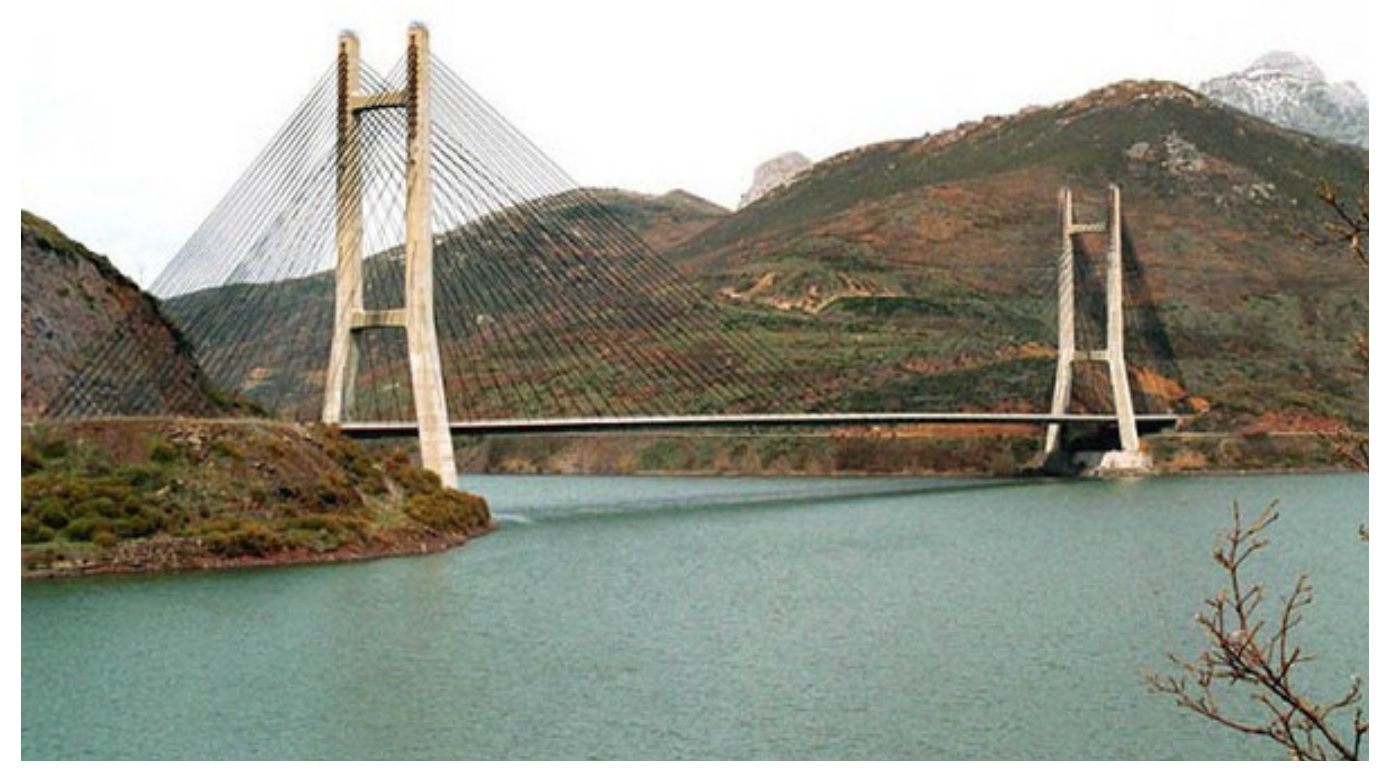

Figura 1.32 - Ponte Barrios de Luna, na Espanha (http://en.structurae.de/photos/index.cfm?JS=67881)

A ponte Barrios de Luna, também chamada de ponte Engenheiro Carlos Fernández Casado, foi construída em 1983 na Espanha e se destaca pela esbeltez do tabuleiro em concreto protendido, que parece flutuar sobre as águas do lago Barrios de Luna. O comprimento total da ponte é de $643 \mathrm{~m}$, sendo o vão principal de $440 \mathrm{~m}$. O tabuleiro de concreto protendido possui $22,5 \mathrm{~m}$ de largura e 2,3 m de espessura. 


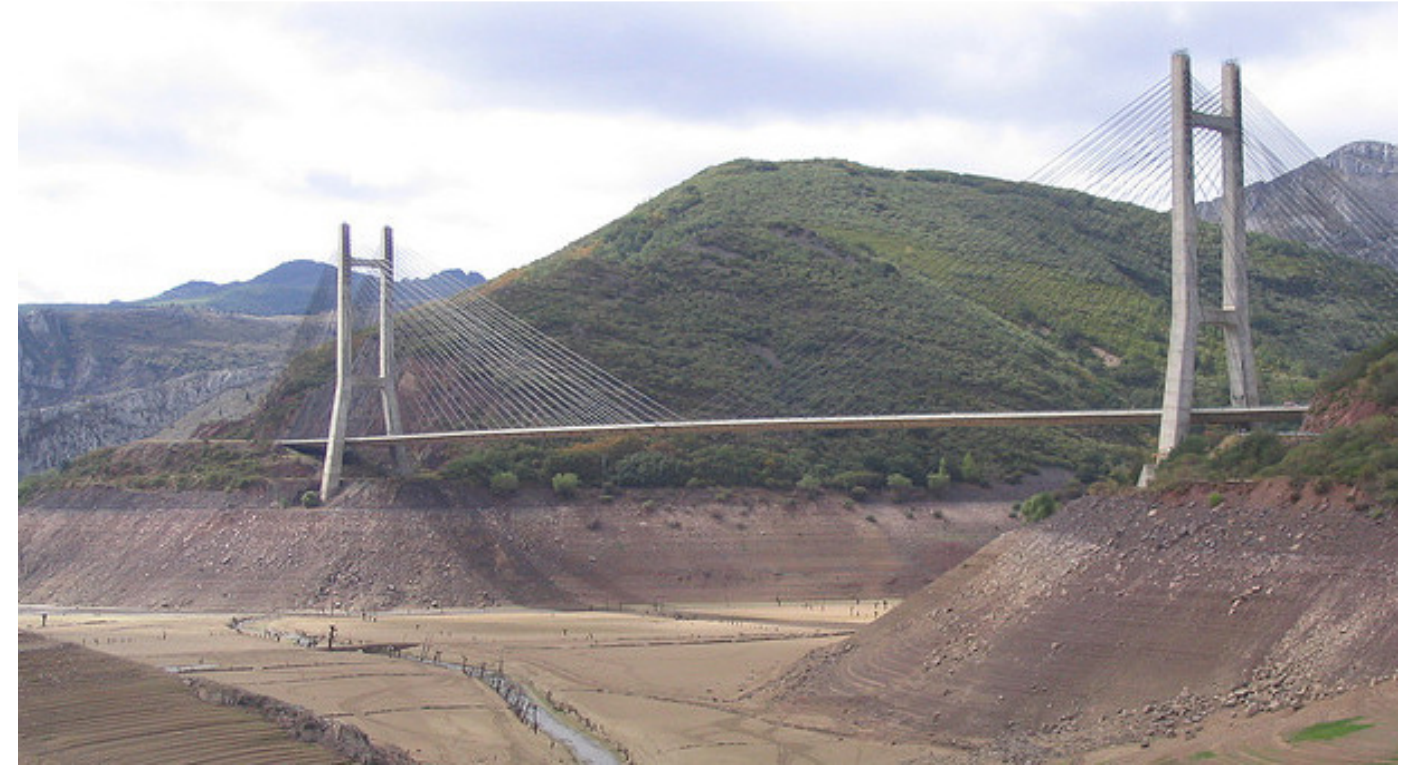

Figura 1.33 - Ponte Barrios de Luna (http://www.flickr.com/photos/berrueta/417766151)

\section{Ponte Alex Fraser:}

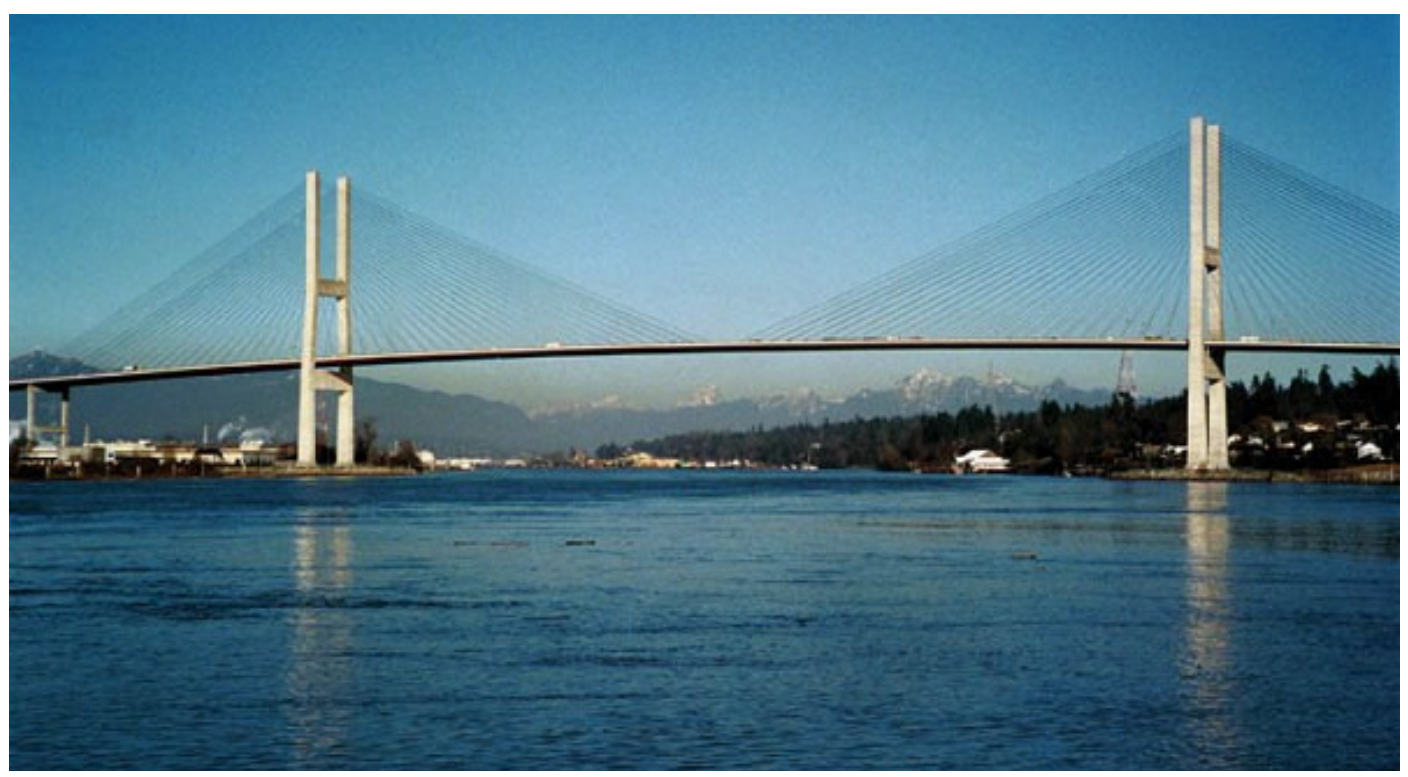

Figura 1.34 - Ponte Alex Fraser, no Canada (http://en.structurae.de/photos/index.cfm?JS=34125)

A ponte Alex Fraser, também conhecida como ponte Annacis, foi construída entre 1983 e 1986, no Canadá. O tabuleiro esbelto, em concreto armado sobre vigas metálicas, possui um vão principal de $465 \mathrm{~m}$ de extensão e $32 \mathrm{~m}$ de largura. Os vãos secundários estaiados possuem $182,75 \mathrm{~m}$ de extensão. 


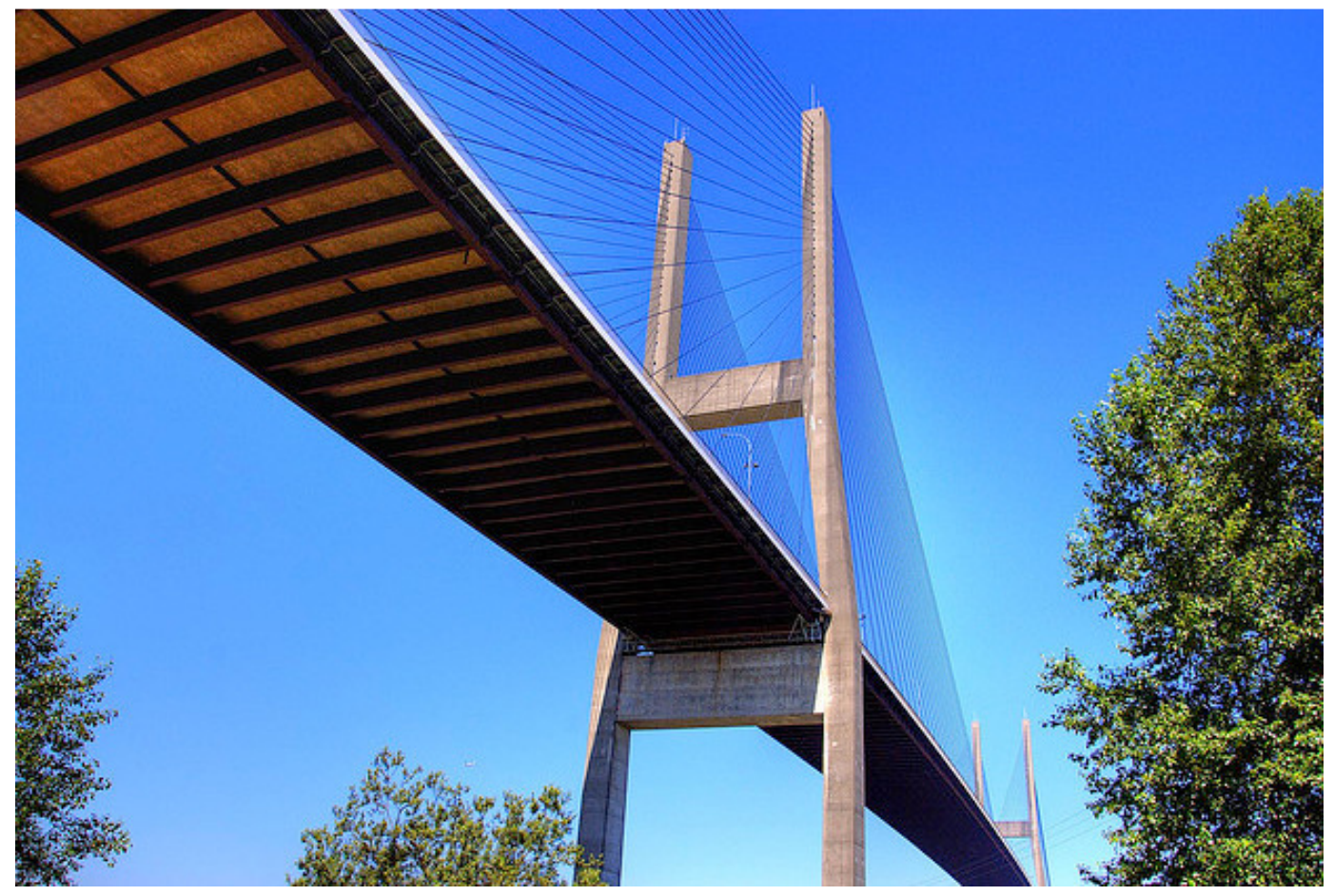

Figura 1.35 - Ponte Alex Fraser (http://www.flickr.com/photos/80651083@N00/753797590)

\section{Ponte Ikuchi:}

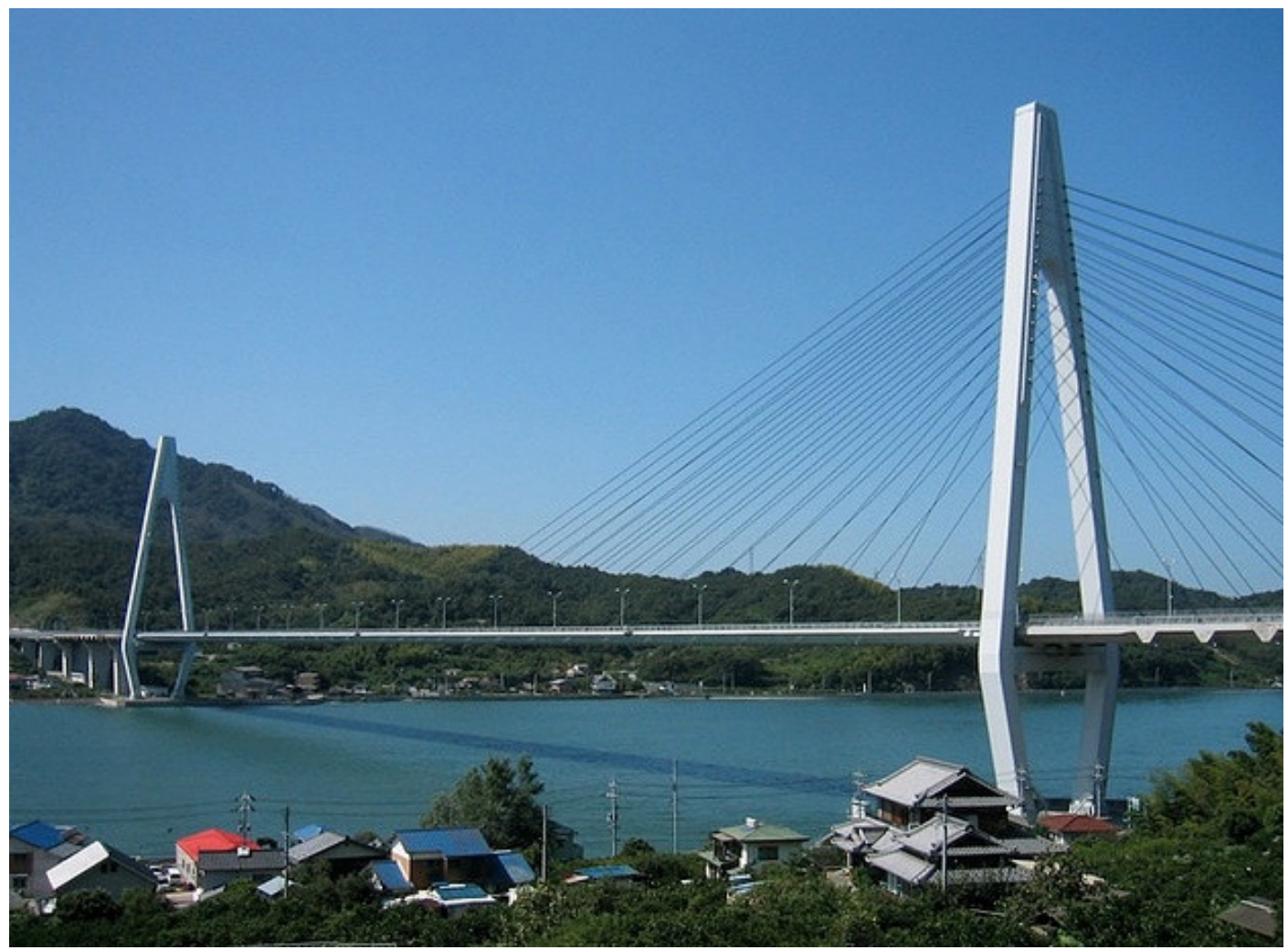

Figura 1.36 - Ponte Ikuchi, no Japão (http://www.flickr.com/photos/onceatraveler/251751898) 
A ponte Ikuchi, construída em 1991 no Japão, possui um comprimento total de $790 \mathrm{~m}$ de extensão, sendo o vão principal um vão de $490 \mathrm{~m}$. O tabuleiro metálico possui uma largura variável de $23,9 \mathrm{~m}$ a $24,1 \mathrm{~m}$. Os mastros da ponte também são metálicos.

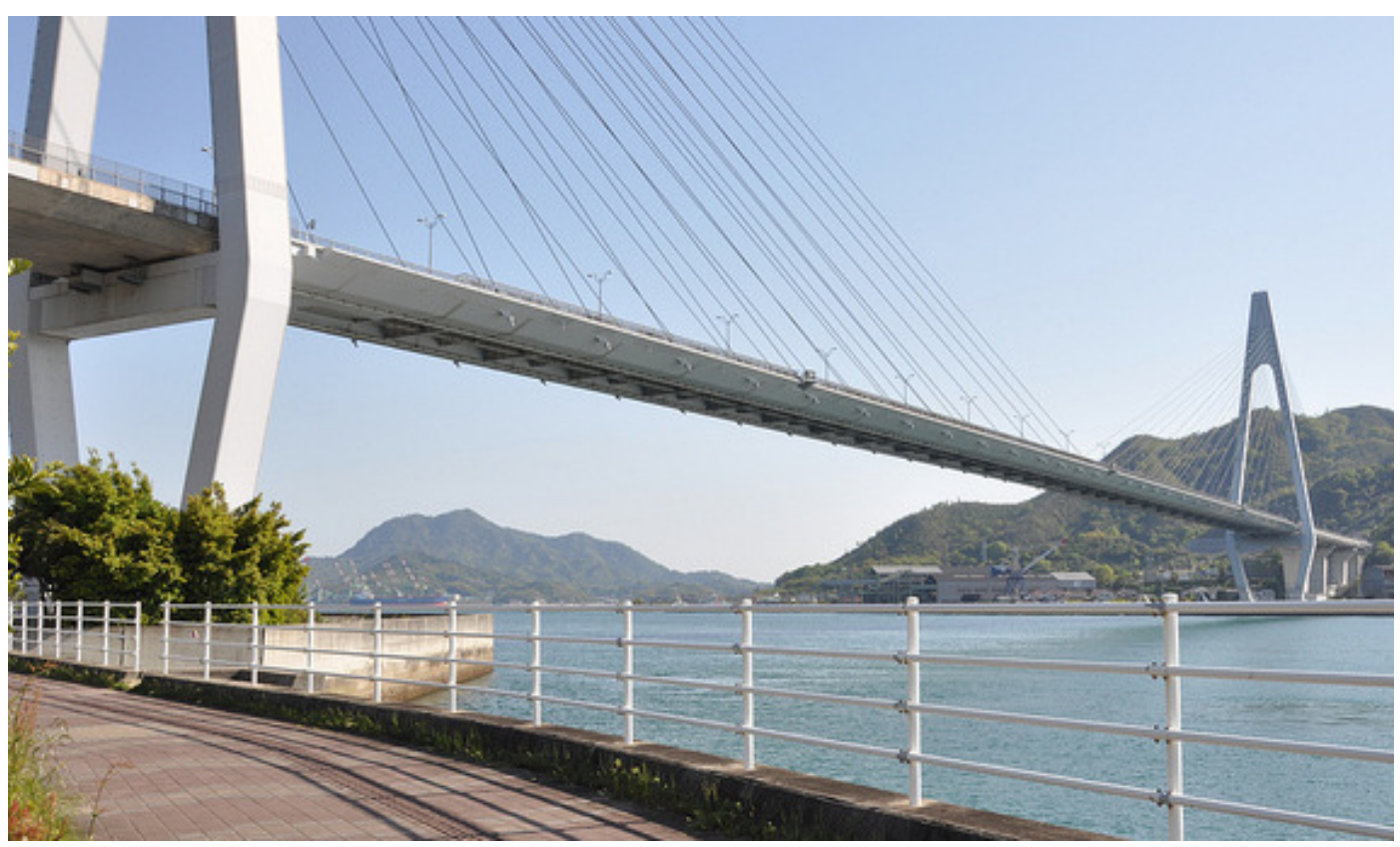

Figura 1.37 - Ponte Ikuchi (http://www.flickr.com/photos/mukarin/4675271208)

\section{Ponte Skarnsundet:}

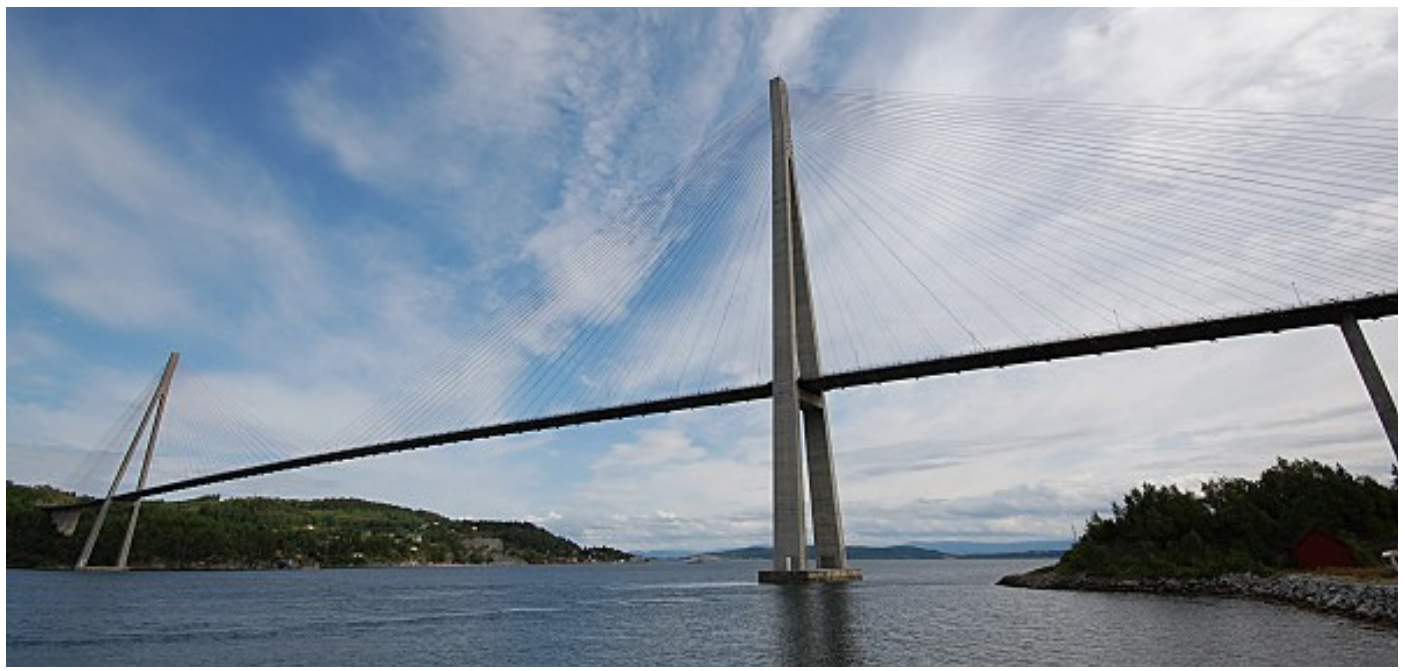

Figura 1.38 - Ponte Skarnsundet, na Noruega (http://en.structurae.de/photos/index.cfm?JS=154763) 
A ponte Skarnsundet foi construída em 1991 na Noruega, com um comprimento total de $1010 \mathrm{~m}$, sendo o vão principal de $530 \mathrm{~m}$. O tabuleiro de concreto possui $13 \mathrm{~m}$ de largura e apenas $2,15 \mathrm{~m}$ de espessura, o que demonstra 0 quão esbelta esta estrutura se apresenta. Os mastros de concreto possuem $152 \mathrm{~m}$ de altura, o que mostra que o vão a ser vencido afeta diretamente a altura necessária para os mastros: quanto maior o vão, maior a altura dos mastros.

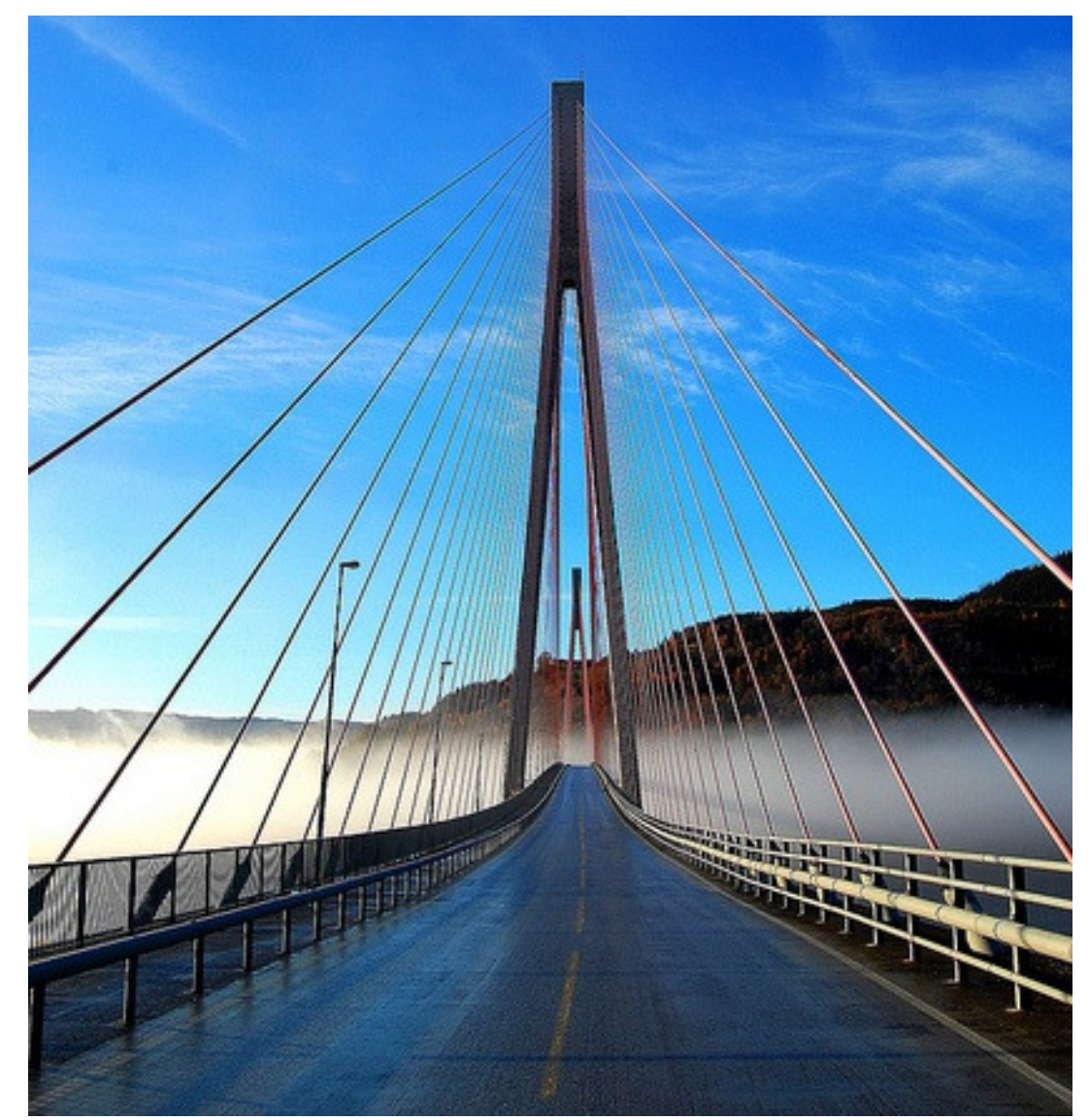

Figura 1.39 - Ponte Skarnsundet (http://www.flickr.com/photos/36685762@N03/5291140189) 


\section{Ponte Yangpu:}

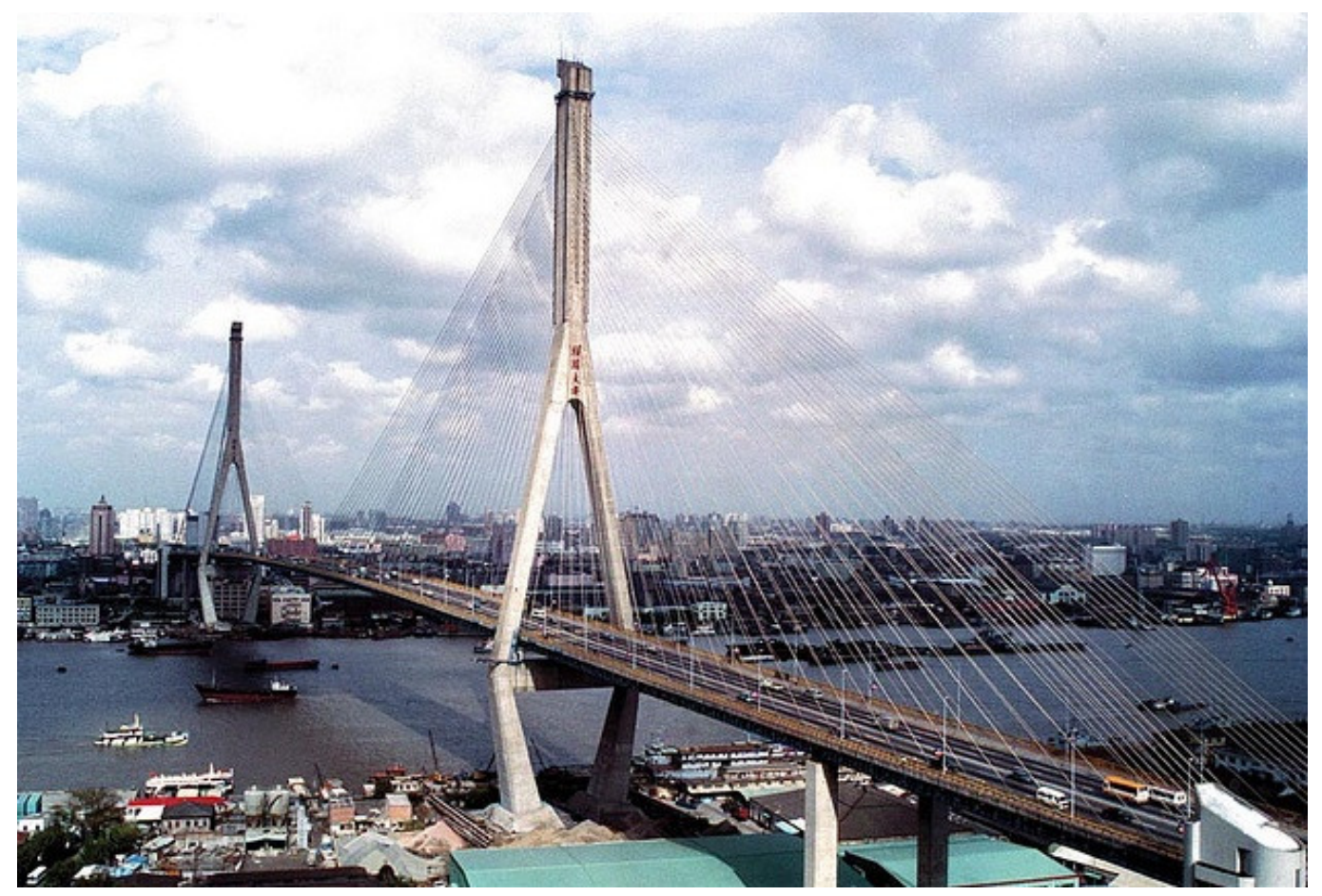

Figura 1.40 - Ponte Yangpu, na China (http://www.flickr.com/photos/bridgink/383329967)

A ponte Yangpu, sobre o rio Huangpu na China, foi inaugurada em 1993, possuindo um comprimento total de $8354 \mathrm{~m}$, sendo o vão principal com $602 \mathrm{~m}$ de extensão. $\mathrm{O}$ tabuleiro é uma estrutura mista de concreto e aço, tendo uma largura de $30,35 \mathrm{~m}$. Os mastros de concreto possuem uma altura de $223 \mathrm{~m}$.

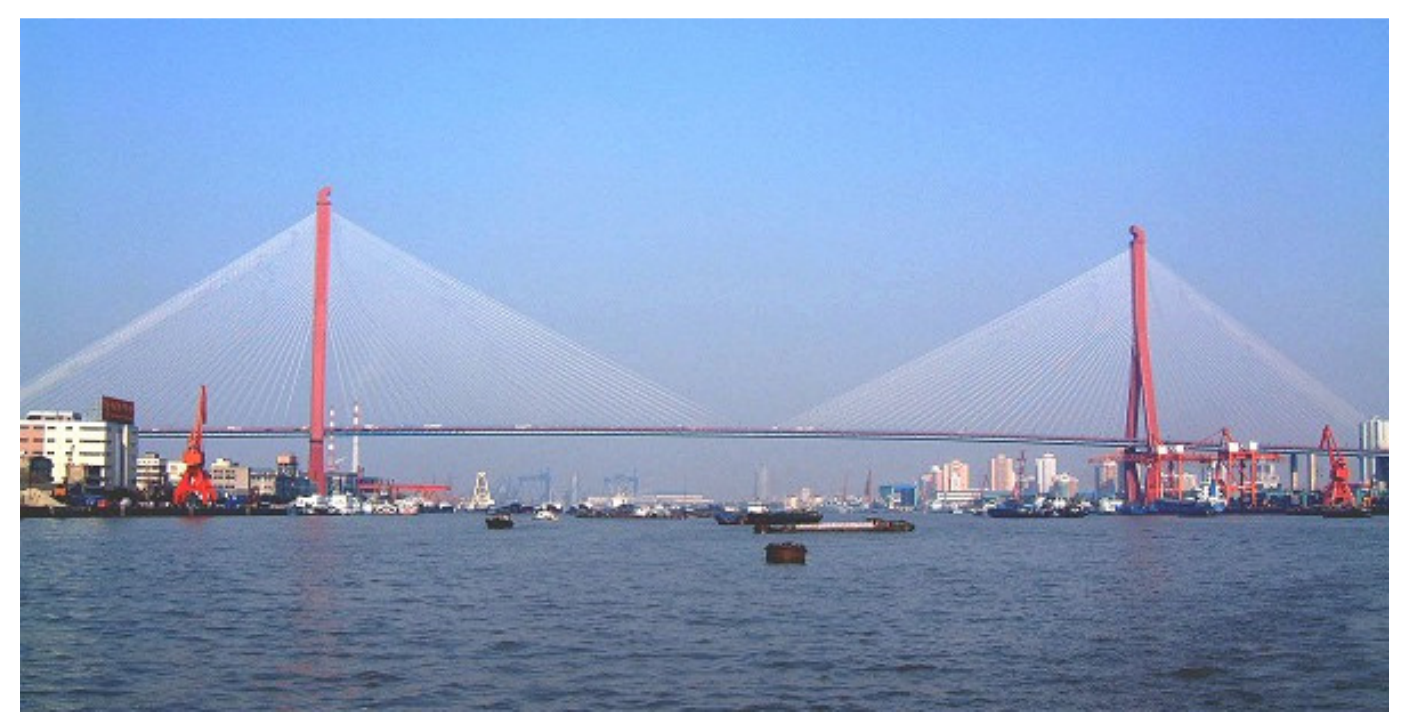

Figura 1.41 - Ponte Yangpu (http://en.structurae.de/photos/index.cfm?JS=40783) 


\section{Ponte da Normandia:}

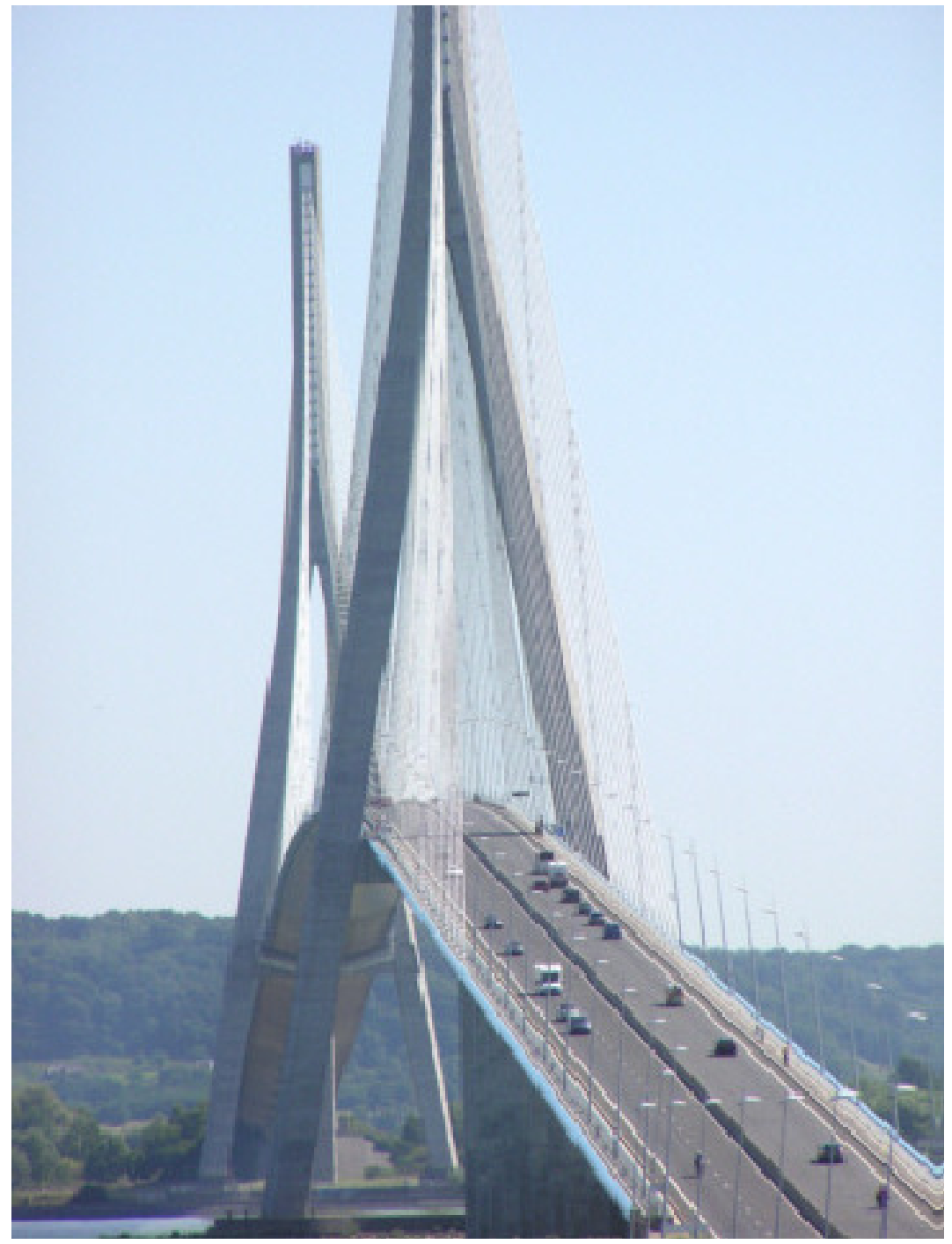

Figura 1.42 - Ponte da Normandia, na França (http://en.structurae.de/photos/index.cfm?JS=67647)

A Ponte da Normandia na França foi construída de 1989 a 1995. Esta ponte, que atravessa o rio Sena, possui um comprimento total de $2141 \mathrm{~m}$, sendo o vão principal de $856 \mathrm{~m}$. O tabuleiro misto de concreto protendido e estrutura metálica tem uma largura variando de 21,2 a 22,3m e uma espessura de 3,0 m. Pelo tempo de execução, percebem-se as dificuldades encontradas na época, uma vez que o vão central da estrutura era muito elevado para as técnicas existentes no início da década de 90.

Nesta obra, foram utilizadas 17.300 toneladas de aço, $80.000 \mathrm{~m}^{3}$ de concreto, 800 toneladas de cordoalhas de protensão e 2.000 toneladas aço para os estais (Structurae). 


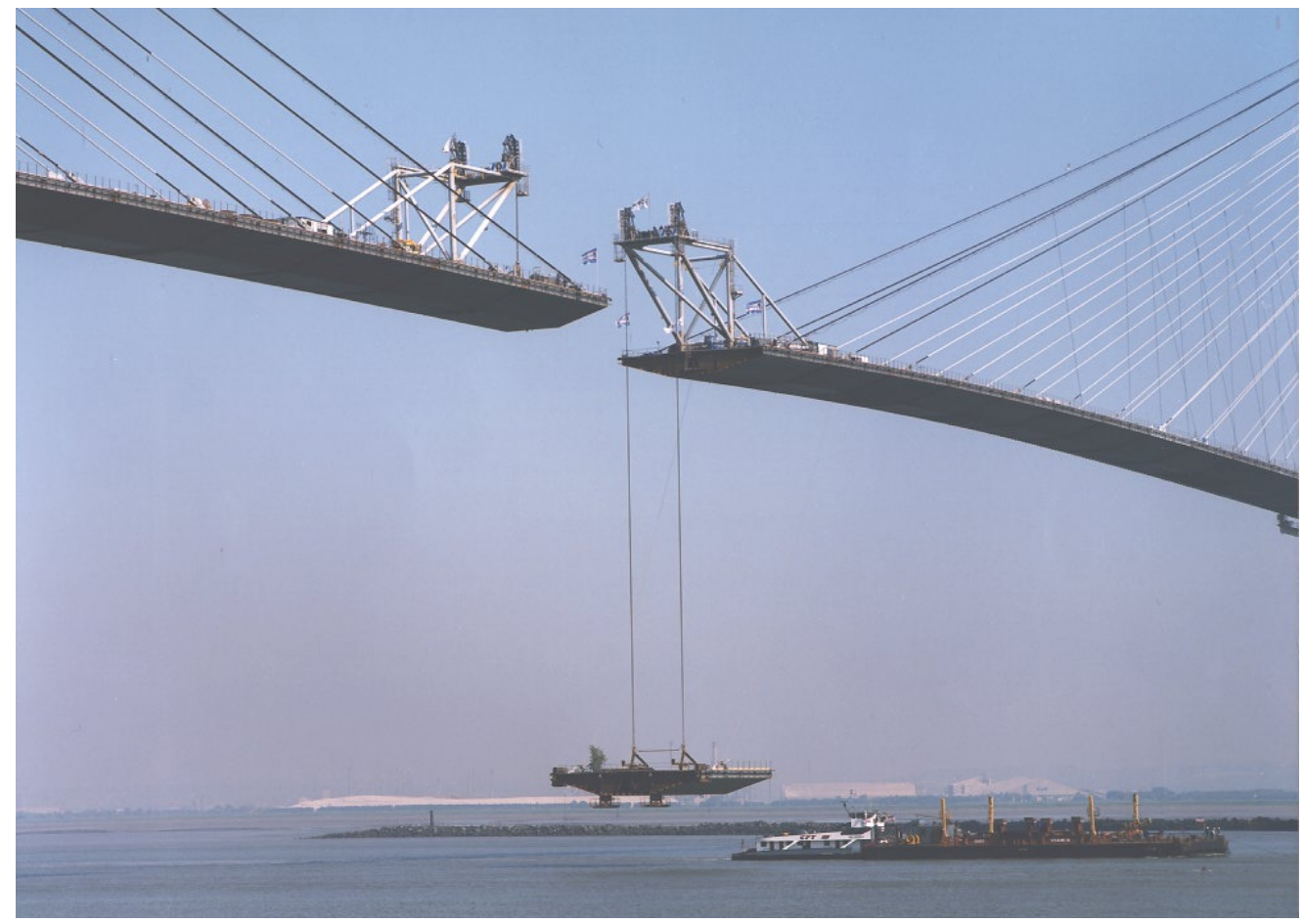

Figura 1.43 - Execução do tabuleiro

(http://www.Imc.ep.usp.br/people/hlinde/Estruturas/images/Historia\%20\%20grandes_pontes/nofoto11.jpg)

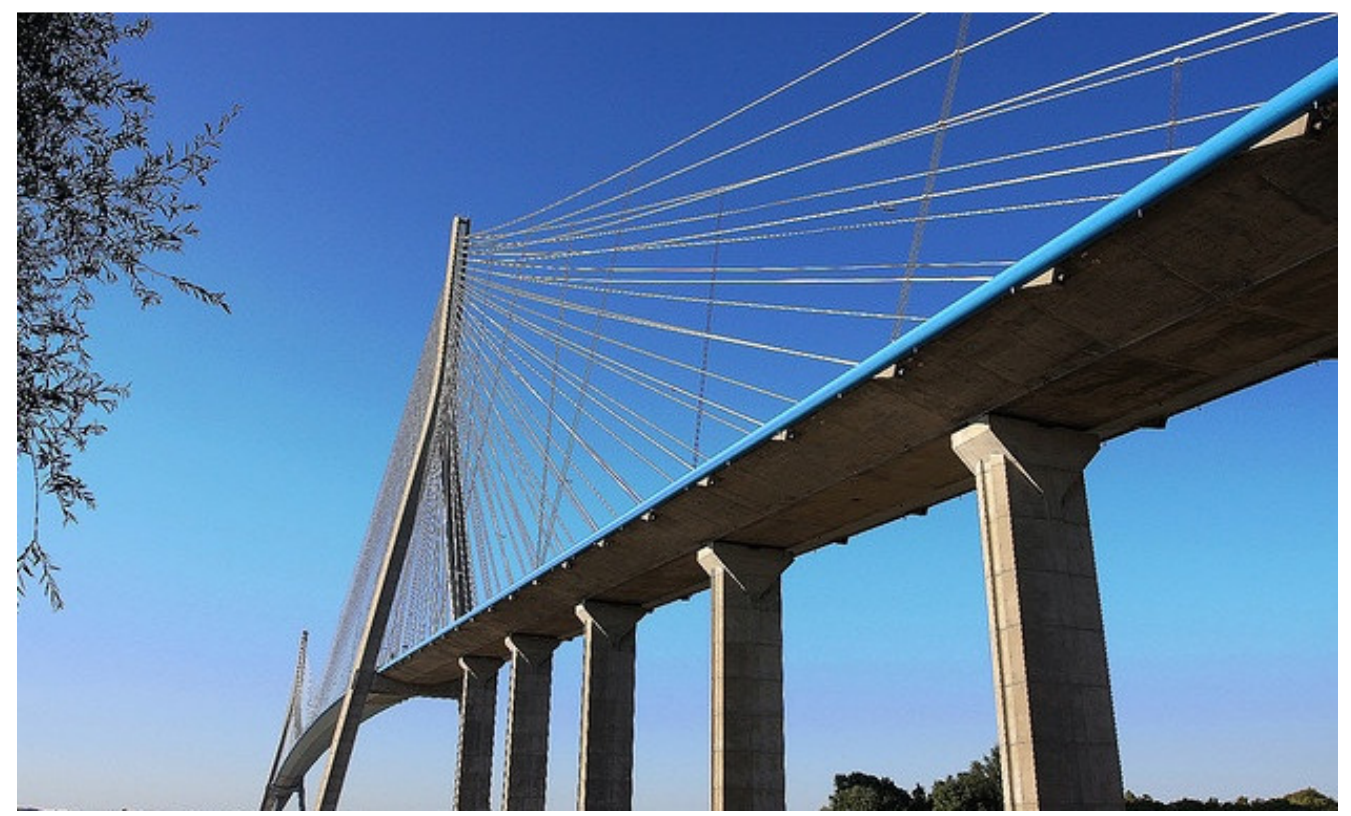

Figura 1.44 - Ponte da Normandia (http://www.flickr.com/photos/lucacarletti/2716747314) 


\section{Ponte Erasmus:}

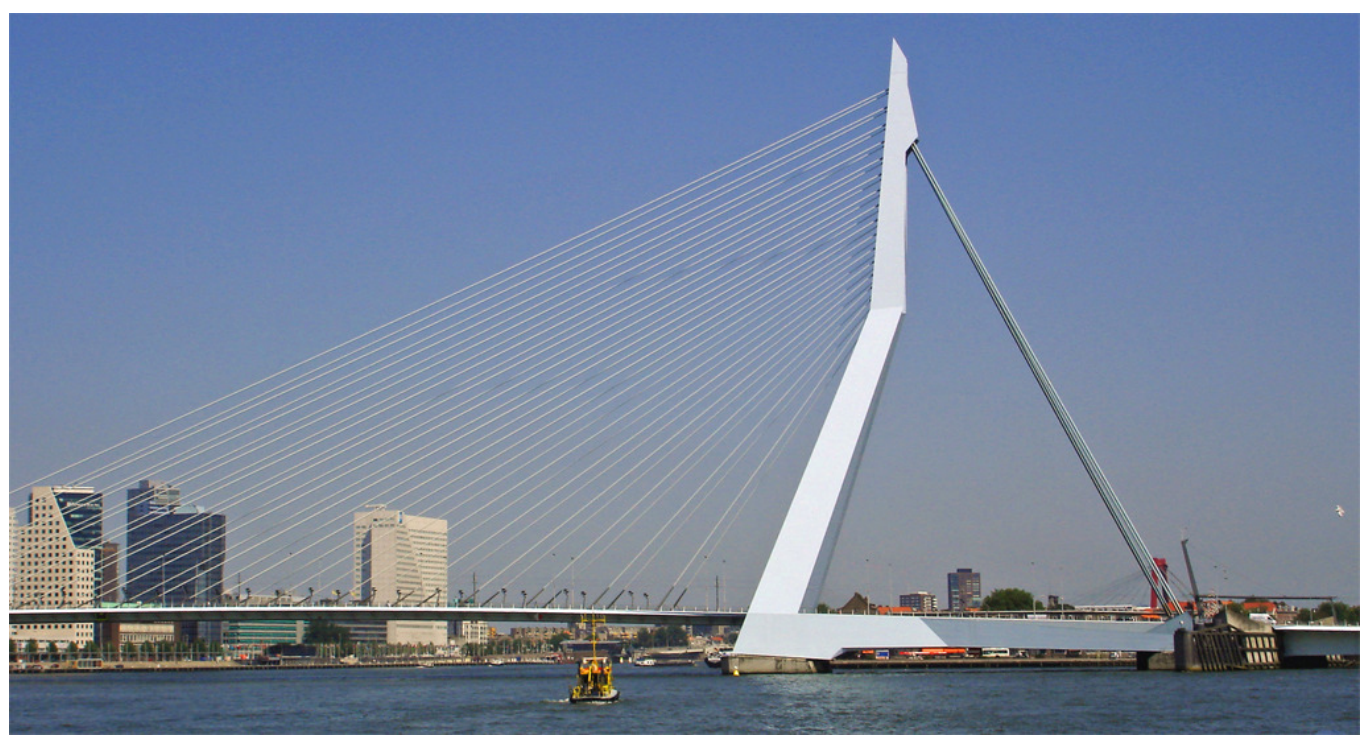

Figura 1.45 - Ponte Erasmus, na Holanda

(http://wassenaardailyphoto.blogspot.com/2007/12/pride-of-rotterdam.html)

A Ponte Erasmus, inaugurada em 1996 em Rotterdam, na Holanda, possui um comprimento total de 802 m, sendo o vão principal estaiado sobre o Rio Meuse de $280 \mathrm{~m}$. Apesar de o vão não ser extenso, comparado às demais pontes construídas nesta mesma época, esta ponte se destaca pela sua geometria inusitada, possuindo um tabuleiro assimétrico e mastro inclinado, ambos metálicos. 


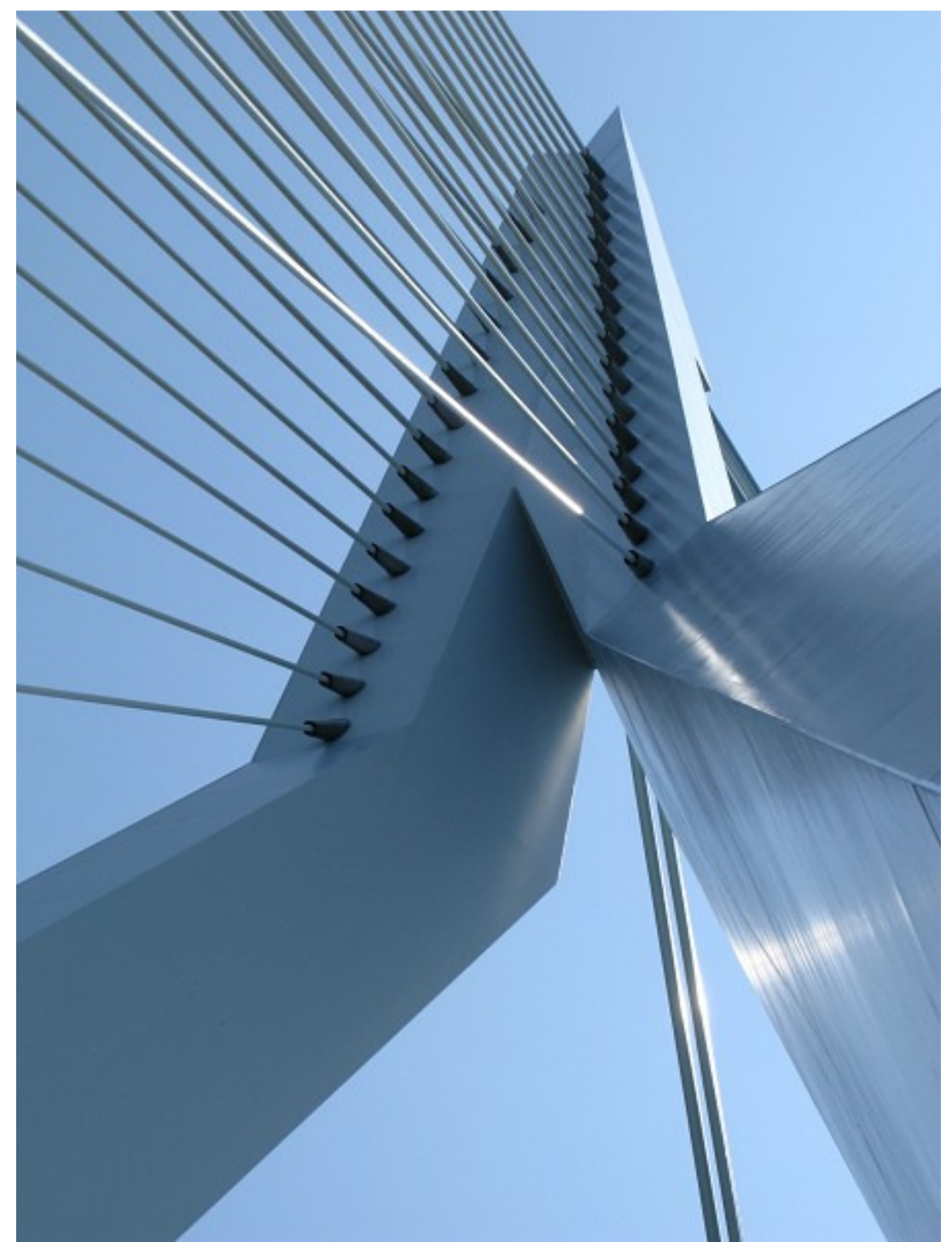

Figura 1.46 - Detalhe da passagem dos estais pelo mastro da Ponte Erasmus (http://en.structurae.de/photos/index.cfm?JS=170442) 


\section{Ponte Tatara:}

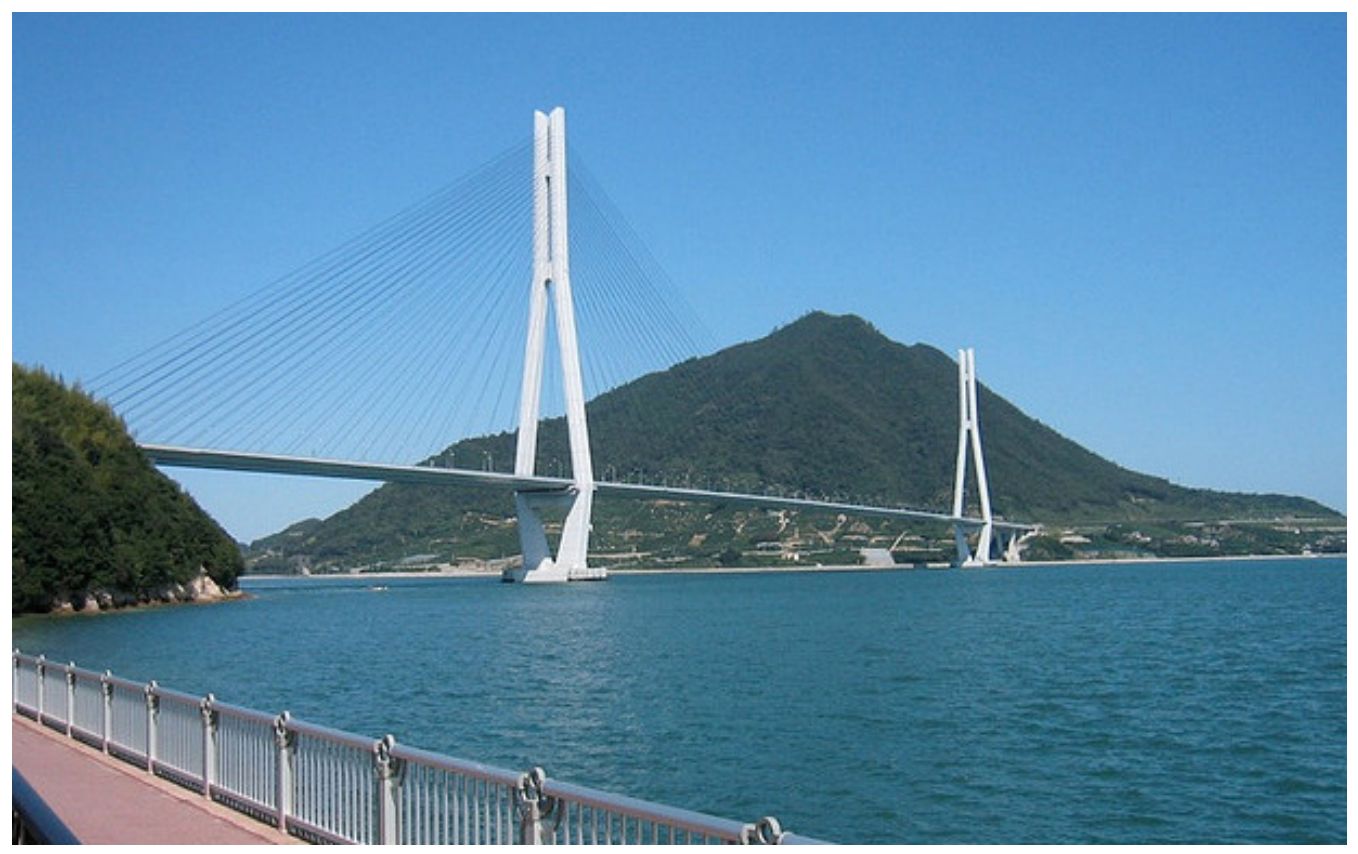

Figura 1.47 - Ponte Tatara, no Japão (http://www.flickr.com/photos/onceatraveler/251753055)

A ponte Tatara, finalizada em 1999 no Japão, possui um comprimento total de $1480 \mathrm{~m}$, com um vão central de $890 \mathrm{~m}$ de extensão e um tabuleiro de concreto de $30,6 \mathrm{~m}$ de largura.

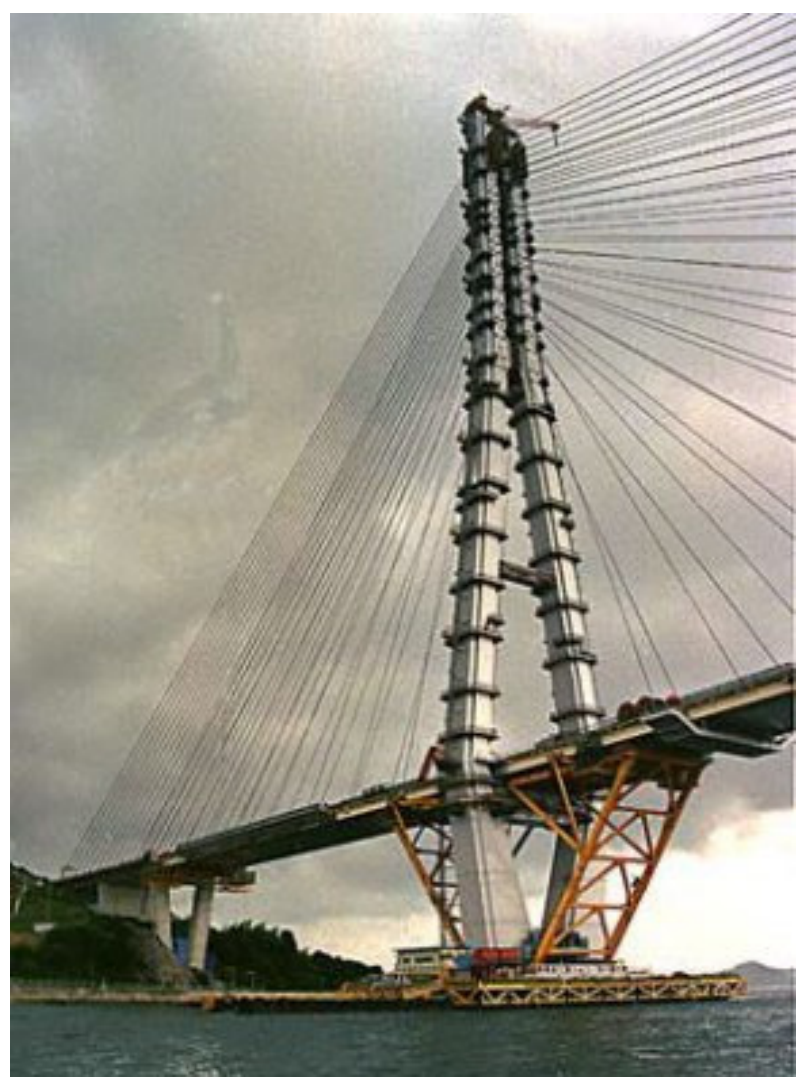

Figura 1.48 - Construção da Ponte Tatara (http://en.structurae.de/photos/index.cfm?JS=28) 
Para possibilitar que os cabos chegassem ao centro do vão no ângulo favorável, os pilares de concreto foram executados até uma altura de $220 \mathrm{~m}$..

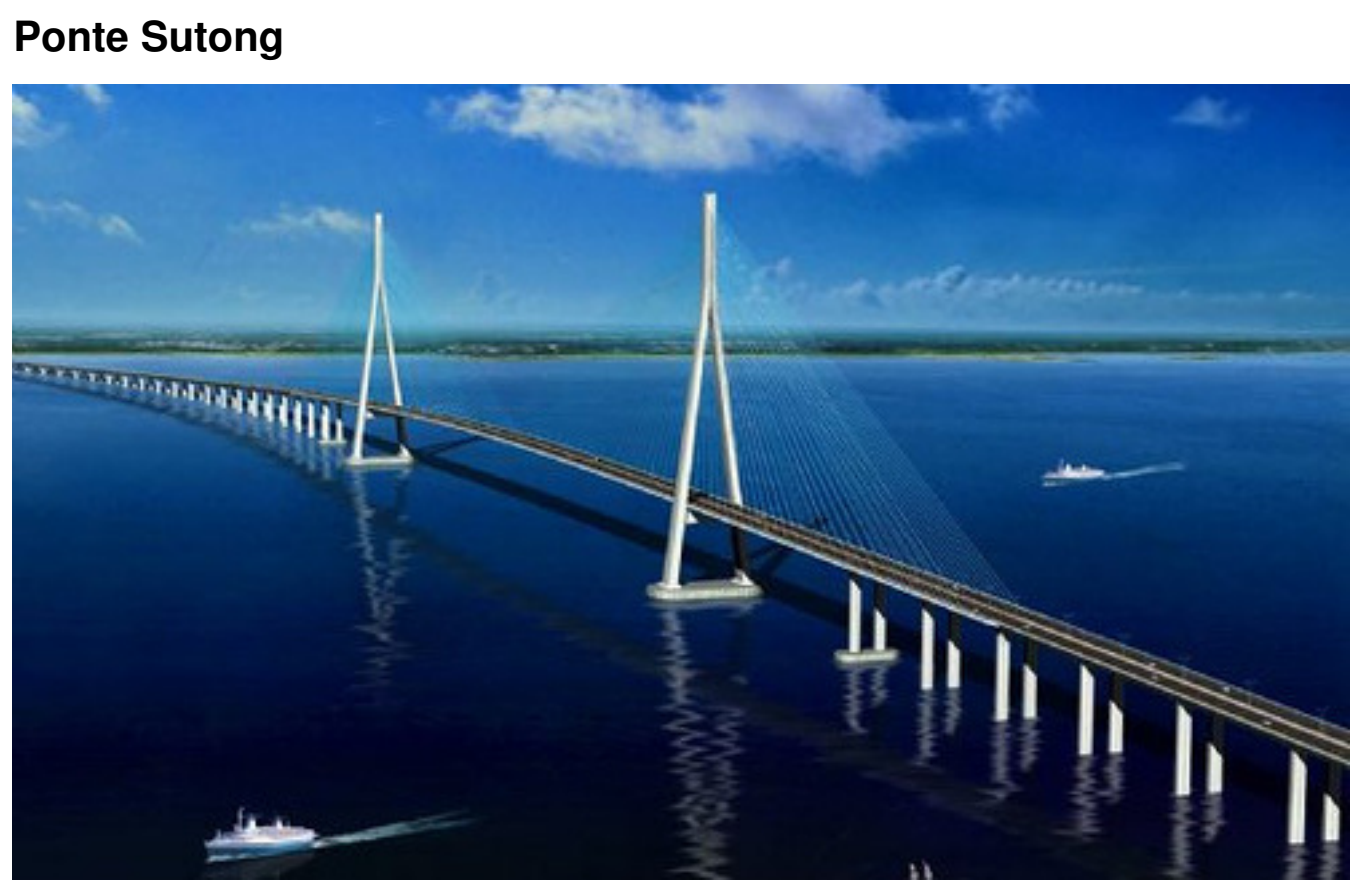

Figura 1.49 - Ponte Sutong, na China (http://www.flickr.com/photos/bridge_space/2158327196)

A ponte Sutong, finalizada em 2008, na China, é atualmente a ponte estaiada mais extensa já construída. Seu comprimento total é de $8146 \mathrm{~m}$, sendo o vão principal de $1088 \mathrm{~m}$ de extensão. $\mathrm{O}$ tabuleiro foi executado em estrutura metálica, e os mastros de concreto possuem uma altura $304,4 \mathrm{~m}$. O custo da obra foi de aproximadamente US\$750.000.000 (Structurae). 


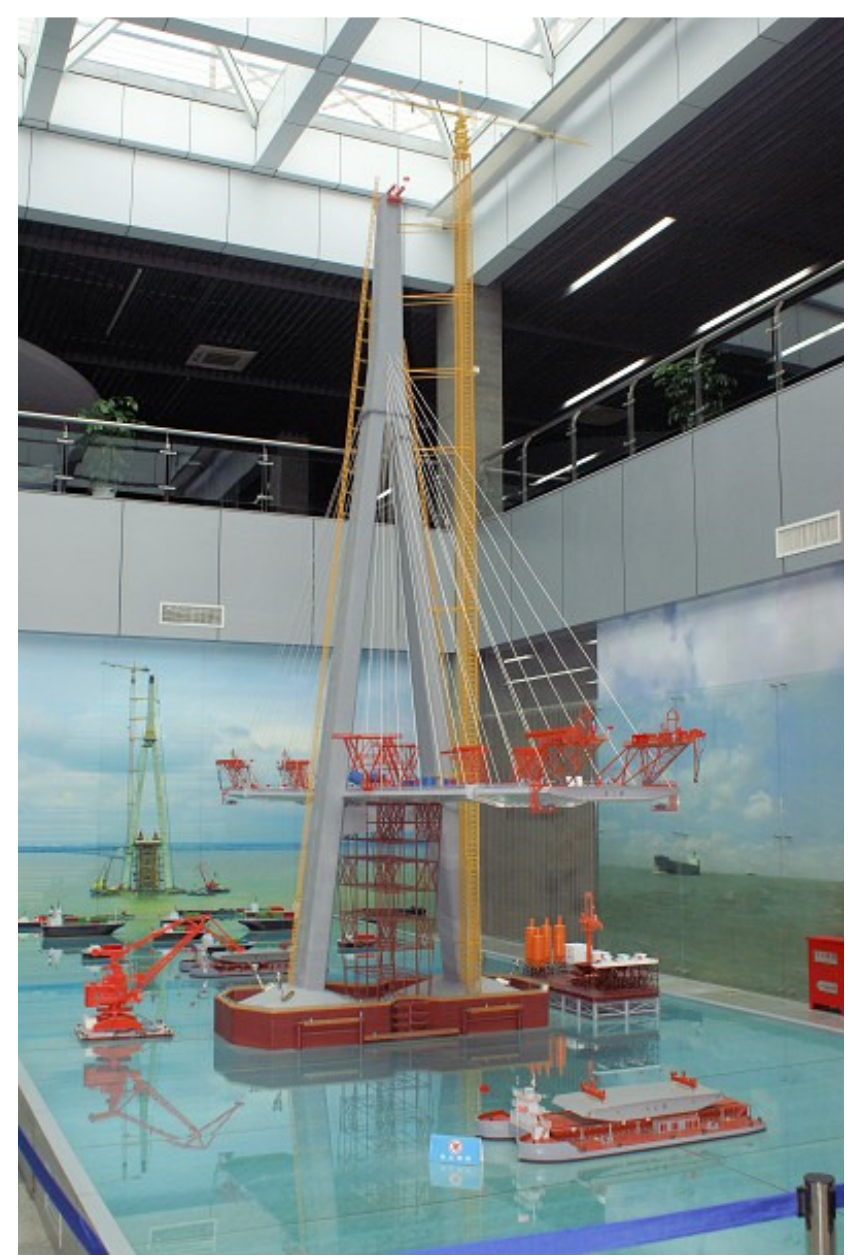

Figura 1.50 - Maquete da construção da Ponte Sutong (http://en.structurae.de/photos/index.cfm?JS=148592)

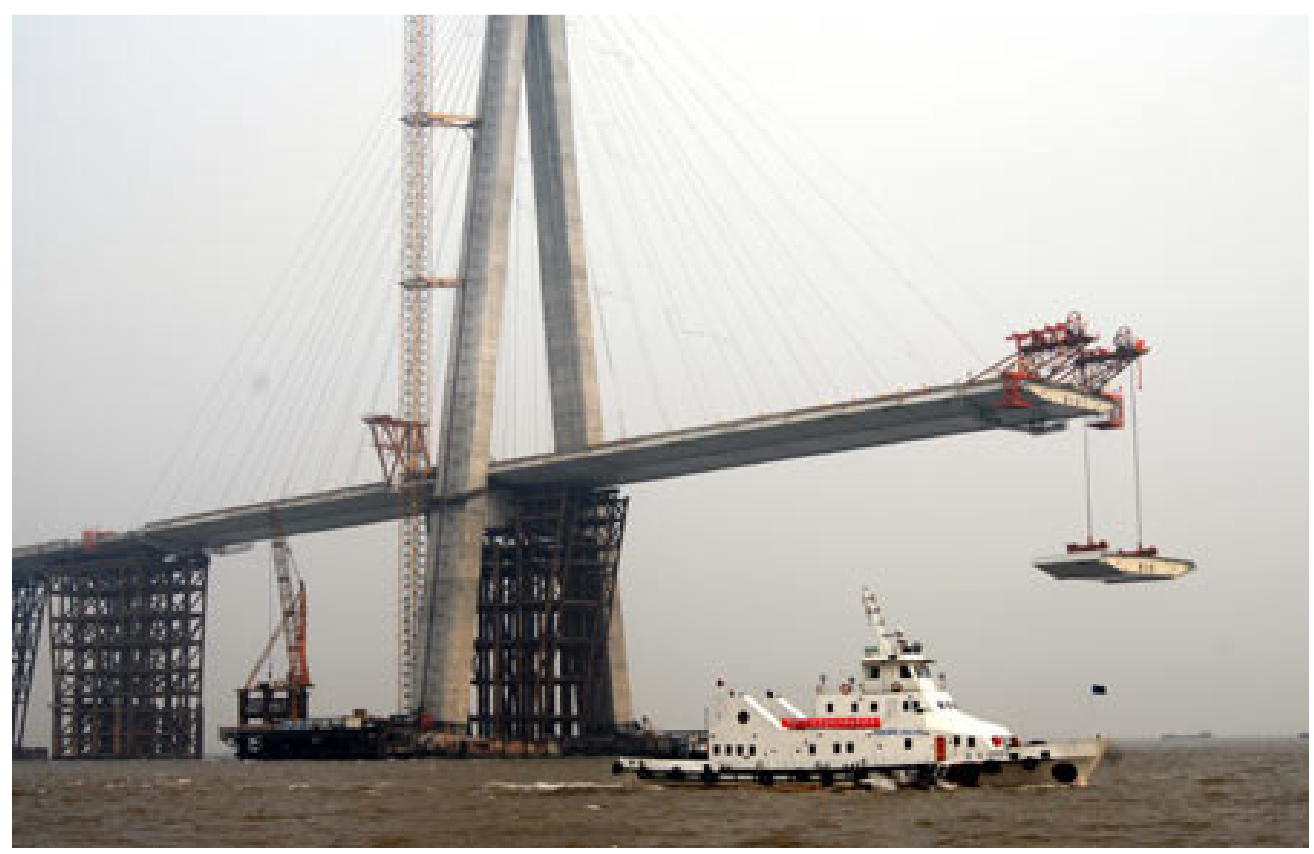

Figura 1.51 - Construção da Ponte Sutong

(http://www.chinadaily.com.cn/photo/att/site1/20070127/xin_4301042717398412670173.jpg) 
Nota-se nestes exemplos como as pontes estaiadas evoluíram nas últimas décadas. Os conceitos usados nas primeiras pontes estaiadas, tais como cabos amplamente espaçados e tabuleiros suficientemente rígidos e espessos para resistir a elevados esforços de momentos longitudinais, foram abandonados. Em seu lugar, foram incorporadas novas técnicas de dimensionamento, que possibilitaram a execução de pontes com elevados vãos e tabuleiros suficientemente esbeltos, que proporcionaram uma redução no peso e custo da estrutura.

Mesmo com toda a tecnologia desenvolvida atualmente, as pontes estaiadas possuem um limite técnico-econômico para o tamanho do vão central, que está por volta de $1500 \mathrm{~m}$ de extensão (Structurae). Isso devido à extensão dos cabos de sustentação e das elevadas cargas de compressão introduzidas pelos mesmos no tabuleiro da ponte. 


\section{ARRANJO ESTRUTURAL}

\subsection{ASPECTOS GERAIS}

As pontes estaiadas consistem, basicamente, em estruturas compostas por um tabuleiro, uma ou mais torres e cabos de sustentação (estais). Esta alternativa às pontes convencionais surgiu nas últimas décadas como alternativa para transpor maiores vãos com estruturas mais leves. Enquanto uma ponte convencional necessita de diversos pontos de apoio para vencer um grande vão, uma ponte estaiada pode vencer o mesmo vão com reduzidos pontos de apoio. Com isso, a solução mostra se menos agressiva ao meio e gera menores interferências com o entorno da obra.

O princípio estrutural das pontes estaiadas não é tão recente quanto as pontes propriamente ditas. Algumas estruturas, tais como passarelas, embarcações e tendas, já usavam cabos como sustentação, conforme pode-se ver nas figura 2.1:

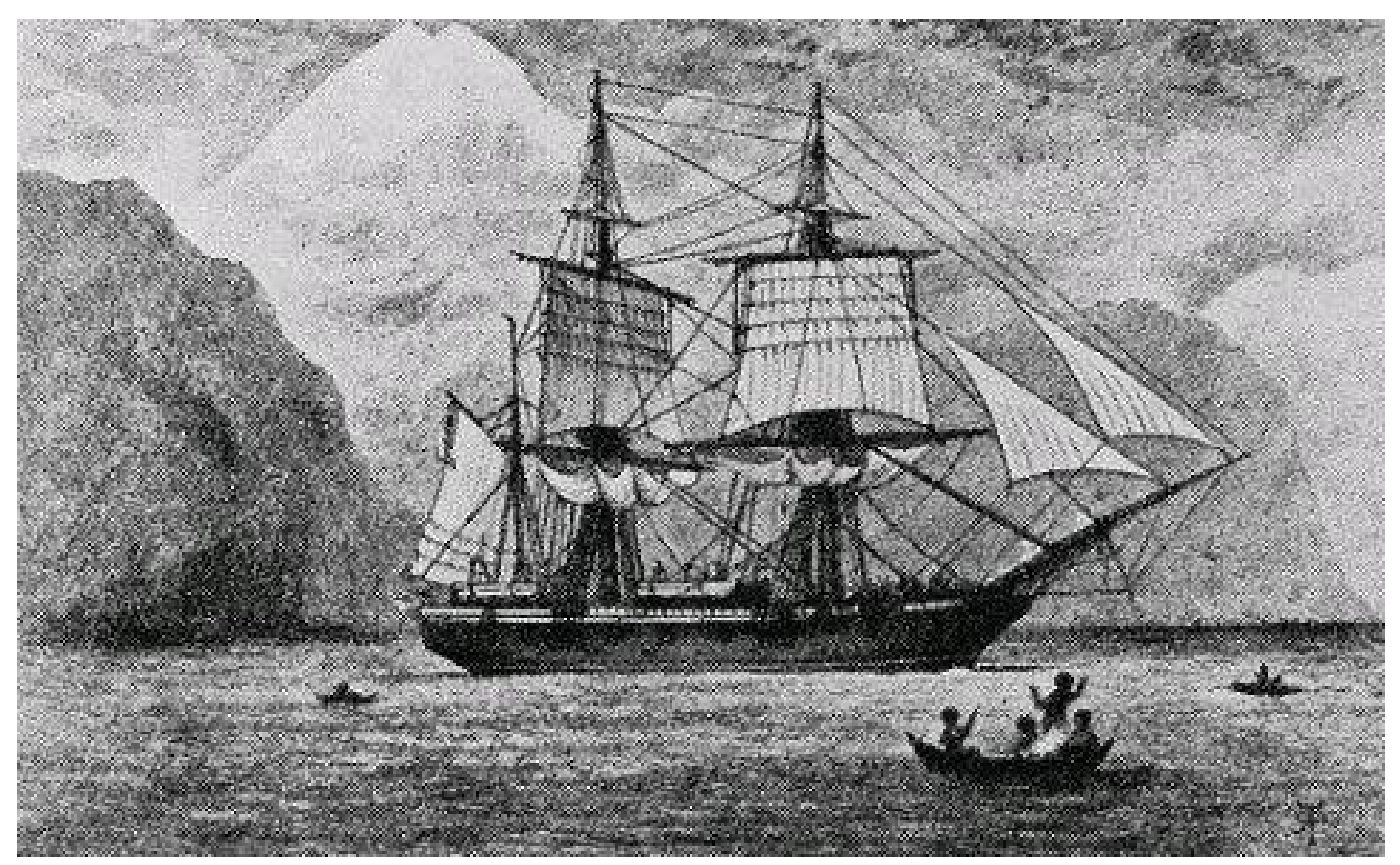

Figura 2.1 - Embarcação antiga

(DARWIN, C. - Viagem de um naturalista ao redor do mundo) 
Nota-se nas embarcações antigas o mesmo princípio das pontes estaiadas: cabos que sustentam as velas, presos em um mastro (pilar).

A aplicação deste tipo de solução estrutural em pontes iniciou-se de uma maneira mais rudimentar, utilizando se madeira e cordas como elementos estruturais. Um exemplo clássico é ponte estaiada de madeira, construída em 1784 pelo carpinteiro alemão Lescher (figura 1.2).

Percebe-se nesse tipo de estrutura que a humanidade começa a buscar novas maneiras de solucionar suas limitações e dificuldades. Para que isso fosse possível, passou-se a buscar materiais e soluções estruturais inovadoras que fossem capazes de atender as suas necessidades. Porém, só com o avanço da tecnologia e da engenharia é que se pode notar uma significativa evolução nas estruturas, tanto nos novos materiais empregados, tanto no sistema estrutural adotado.

Analisando as estruturas recentes, percebe-se que o bom desempenho estrutural das mesmas se dá devido à utilização racional dos materiais empregados, ou seja, obtêm-se dos materiais as suas melhores qualidades mecânicas. Sendo assim, faz-se uso da boa resistência do aço à tração e da boa resistência do concreto à compressão, fazendo com que os materiais trabalhem de maneira otimizada.

Dessa maneira, podem-se obter estruturas mais esbeltas e leves que muitas das estruturas convencionais. Além disso, as pontes estaiadas levam grande vantagem no ponto de vista arquitetônico e têm grande aceitação, tanto no meio técnico, quanto na população em geral. 


\subsection{COMPONENTES ESTRUTURAIS}

A fim de melhor descrever o funcionamento e comportamento das pontes estaiadas será feita uma análise de maneira isolada de cada componente estrutural que compõe este sistema, sendo os mesmos indicados na figura a seguir:

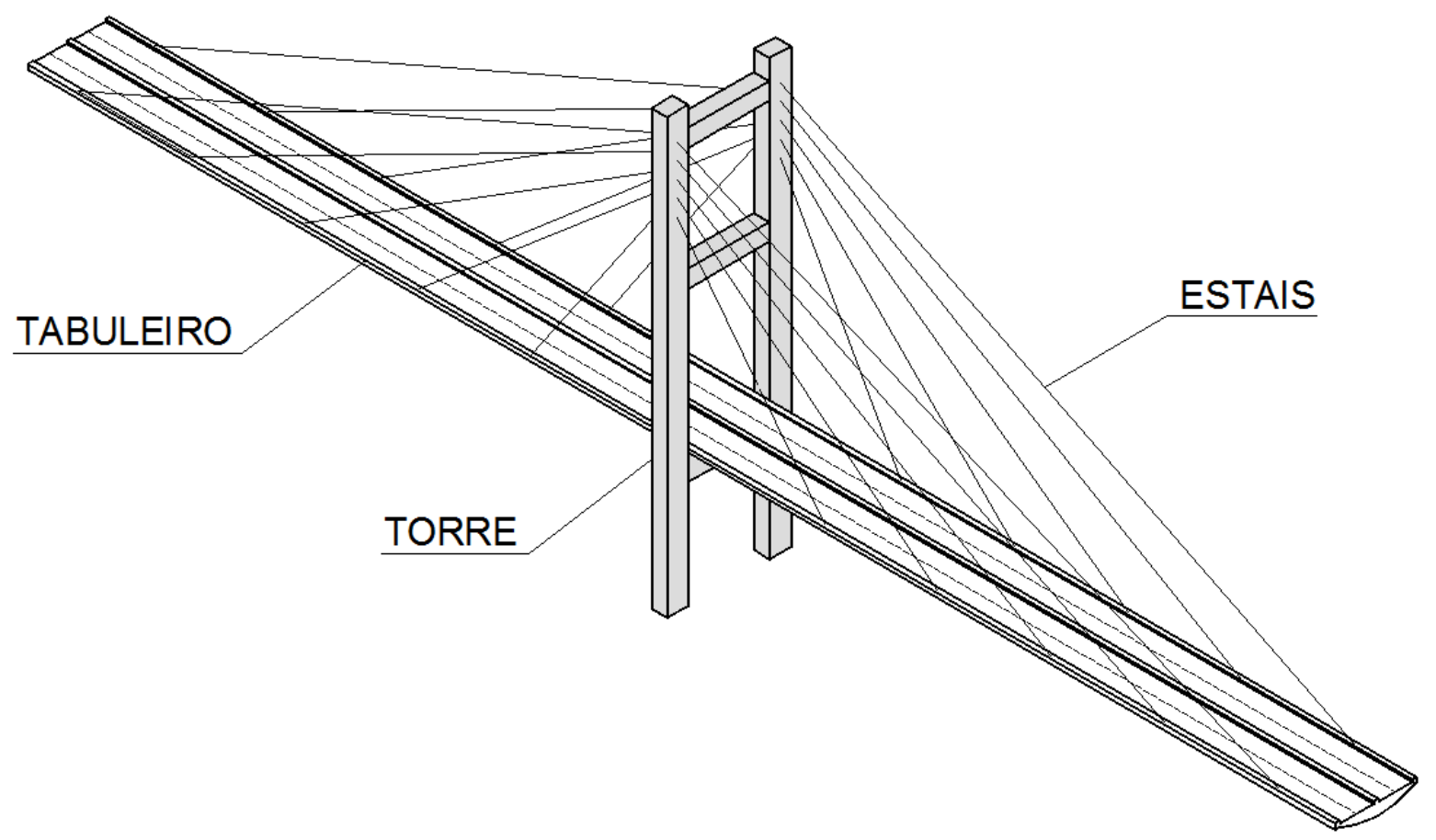

Figura 2.2 - Componentes Estruturais

Primeiramente vale salientar alguns aspectos da evolução da geometria empregada nas pontes estaiadas, separados em três categorias distintas de pontes estaiadas, conforme mostrado a seguir.

- CATEGORIA 1

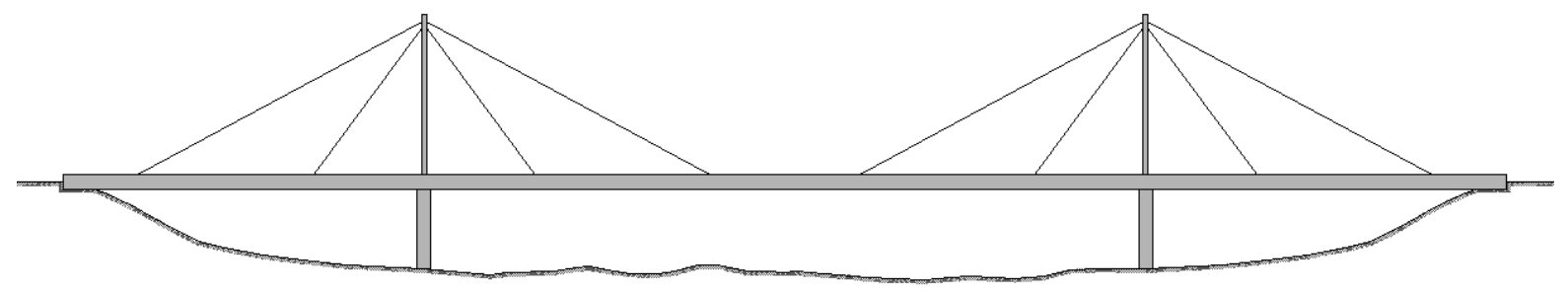

Figura 2.3 - Geometria da Categoria 1 
Nesta categoria de pontes estaiadas o espaçamento longitudinal dos estais é grande, o que exige uma elevada rigidez do tabuleiro. Este deve ser capaz de resistir a elevados esforços de flexão longitudinal. Além disso, como os estais são muito espaçados, a carga que os mesmos devem resistir é maior que nas demais soluções, fazendo com que os mesmos tenham uma grande seção.

Este tipo de configuração foi muito comum durante a construção das primeiras pontes estaiadas modernas, nas quais os vãos não eram muito extensos. Porém, quando há a existência de grandes vãos este tipo de solução começa a ter seus pontos fracos, uma vez que o tabuleiro passa a ter a necessidade de uma elevada rigidez às flexões longitudinais, tendo em vista os elevados espaçamentos dos pontos de fixação dos estais. Devido a este mesmo fator, a carga resistida por cada estai é elevada, necessitando de seções maiores.

Outro fator que possui influência neste tipo de geometria é o método construtivo, uma vez que é necessário construir uma grande extensão de tabuleiro até que se atinja o próximo ponto de fixação do estai.

Um exemplo típico desta categoria é a ponte Maracaibo, construída na Venezuela (Figura 1.18).

\section{- CATEGORIA 2}

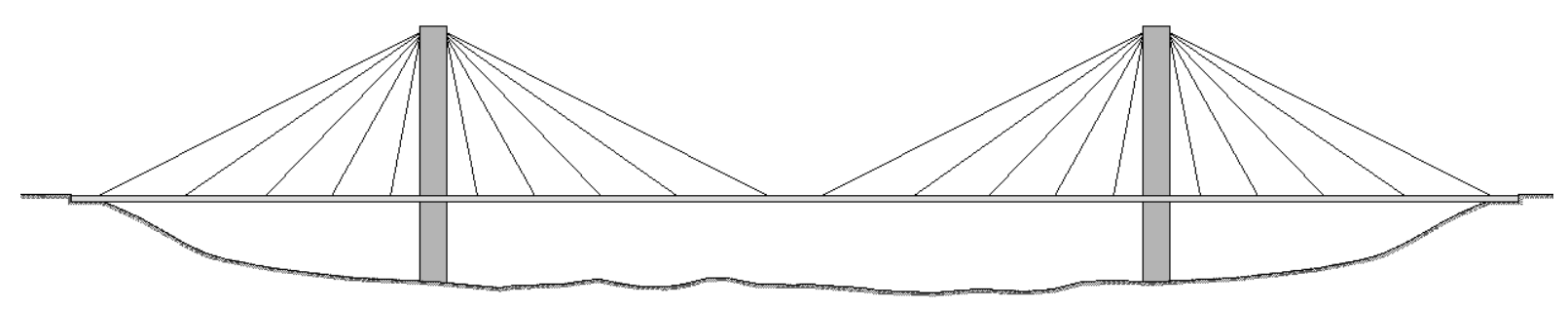

Figura 2.4 - Geometria da Categoria 2

$\mathrm{Na}$ categoria 2 nota-se que pela proximidade dos pontos de ancoragem dos estais, os mesmos passam a assumir maior responsabilidade de suporte dos carregamentos atuantes no tabuleiro, uma vez que a flexão longitudinal atuante é reduzida, havendo basicamente o momento transversal. Sendo assim, com essa redução de esforços, o tabuleiro passa a ter uma geometria mais leve e esbelta, contribuindo significativamente ao fator estético. 
Uma grande vantagem deste método é a possibilidade de o tabuleiro se tornar uma estrutura leve e esbelta, principalmente se o espaçamento entre os cabos for reduzido. Isso é possível, pois a proximidade dos pontos de ancoragem dos estais no tabuleiro reduz o efeito de flexão longitudinal do mesmo. Outro fator importante é a maior verticalidade com que os estais chegam ao tabuleiro, reduzindo significativamente os esforços horizontais introduzidos no mesmo.

Este tipo de geometria favoreceu a difusão do método das aduelas sucessivas, que permite que os tabuleiros sejam executados a partir das torres em direção aos vãos, aproveitando os trechos já executados como apoio.

\section{- CATEGORIA 3}

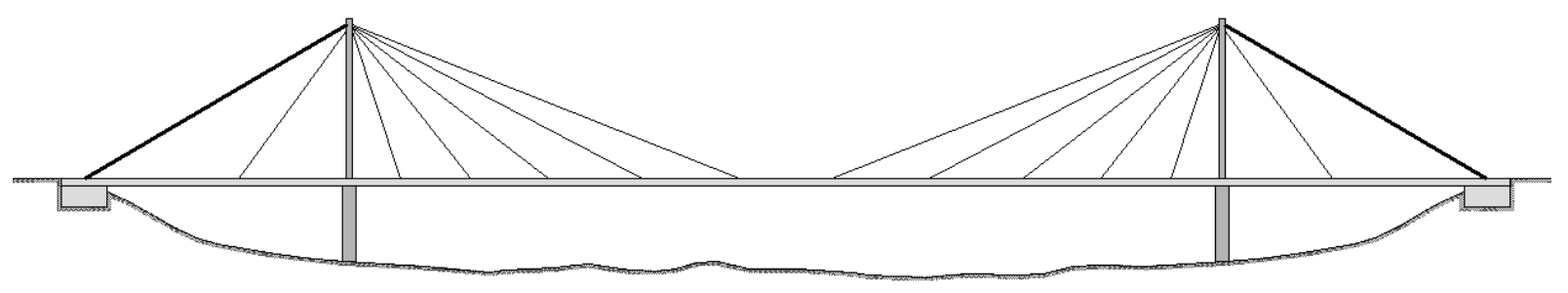

Figura 2.5 - Geometria da Categoria 3

As pontes da categoria 3 têm um diferencial muito útil em diversos casos: a não simetria. As cargas atuantes nestas estruturas passam a não ter a necessidade de serem estabilizadas nos pilares, podendo transmitir essas carga para um elemento externo capaz de resisti-la e garantir estabilidade ao conjunto, conforme mostrado na figura 2.6 .

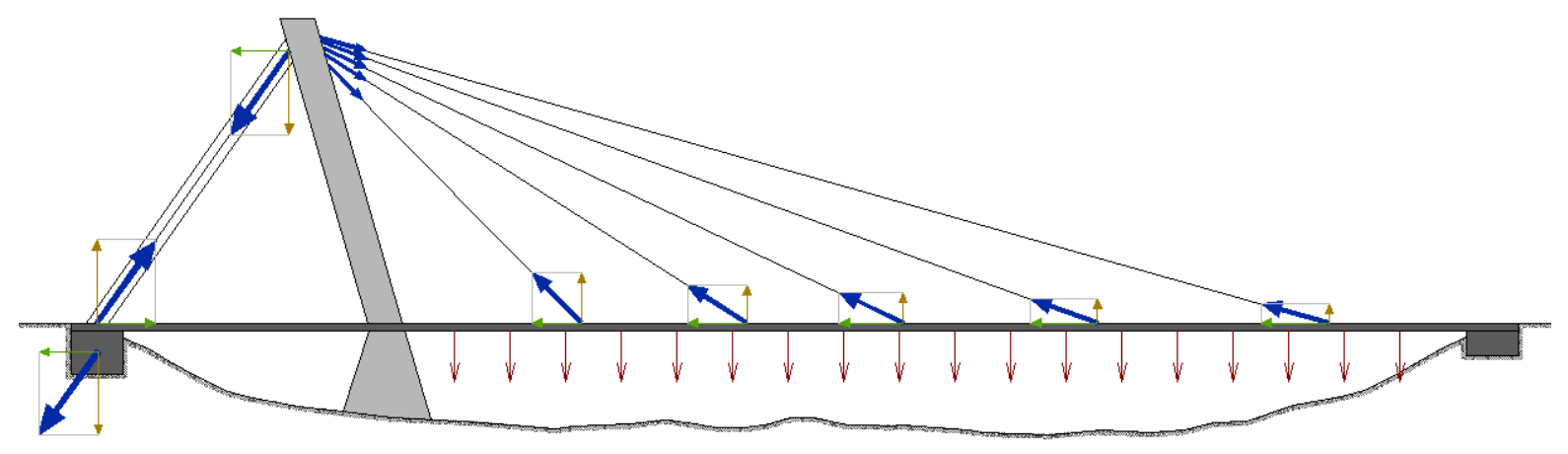

Figura 2.6 - Esforços atuantes nos estais das pontes estaiadas da Categoria 3 
Nota-se na figura 2.6 que, para a estabilidade do conjunto houve a necessidade da utilização de um bloco de ancoragem. Estes blocos normalmente são estruturas de grandes dimensões e, por conseqüência, de elevado peso próprio, capaz de resistir aos esforços provenientes dos estais que sustentam o tabuleiro.

Este tipo de solução é muito útil quanto não há a possibilidade da execução de pilares no centro do vão, seja por interferência em alguma estrutura já existente ou devido a um fator topográfico.

Como exemplo deste tipo de geometria pode-se destacar a Ponte Knee, na Alemanha, por ser uma das primeiras pontes estaiadas assimétricas construídas

(Figura 1.14), e a Ponte Erasmus, na Holanda, que se destaca pela sua geometria diferenciada (Figura 1.44).

Nota-se que as pontes estaiadas podem variar sua geometria de diversas maneiras, dependendo das necessidades ou do aspecto visual desejado. Para que isso seja possível há inúmeras maneiras de se dispor os seus componentes estruturais: distribuição longitudinal e transversal dos estais, tipos de vinculações, ancoragem dos cabos, seção e geometria de torres e tabuleiros, metodologias construtivas, materiais empregados e aspectos visuais. Tudo isto faz com que as pontes estaiadas vivam hoje seu momento de glória, sendo vistas como motivo de orgulho e cartão postal das cidades onde são construídas.

\subsubsection{ESTAIS}

O estai é o elemento estrutural de uma ponte estaiada responsável pela transferência dos carregamentos atuantes no tabuleiro diretamente para o mastro.

Os estais são compostos basicamente por:

- elementos de tensionamento

- sistemas de ancoragem

- sistemas de proteção 


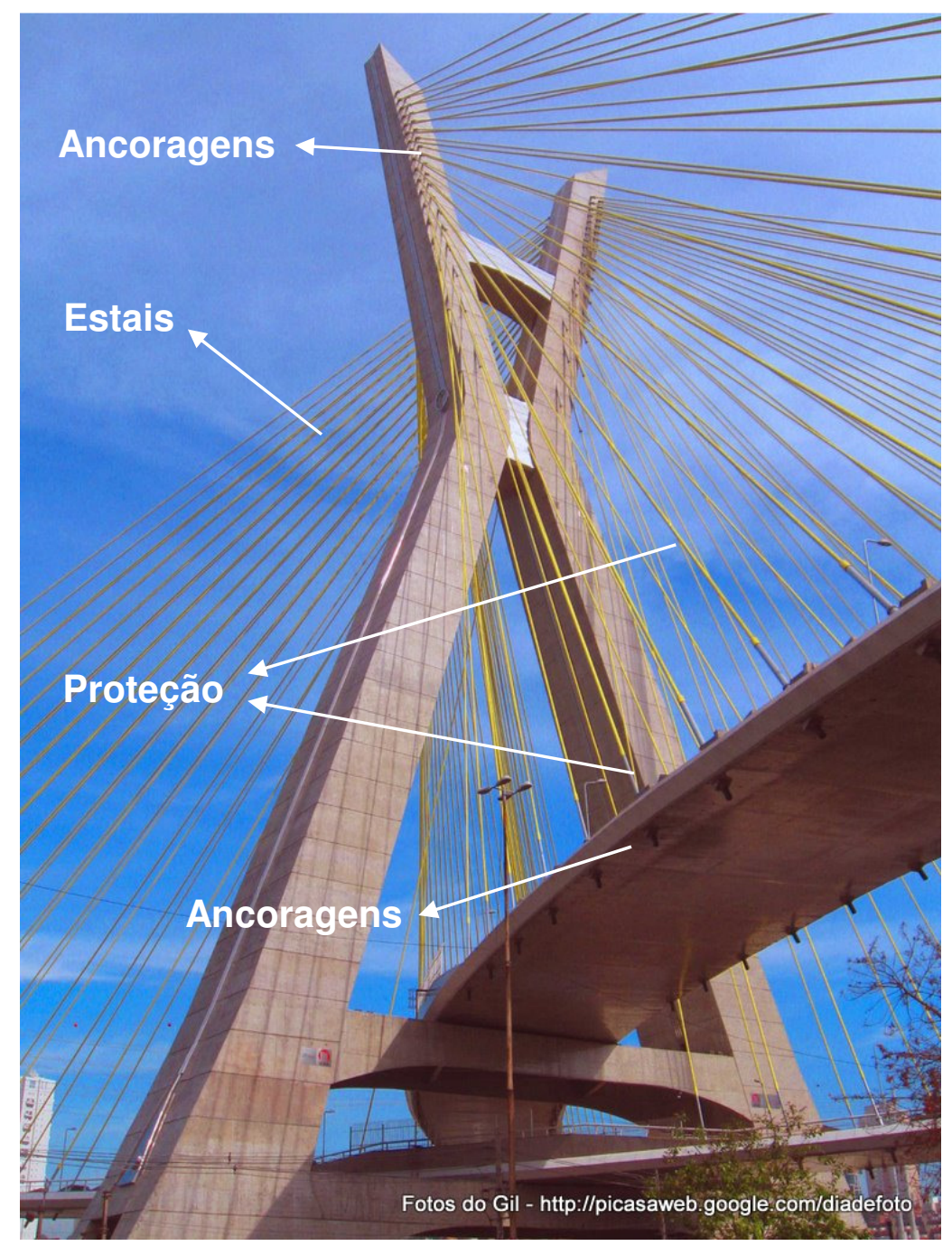

Figura 2.7 - Componentes dos estais - Ponte Octavio Frias e Oliveira (http://picasaweb.google.com/lh/photo/NnIVp3YuB1cpQyMYdyGxww)

Para uma melhor compreensão da função de cada componente que constitui o estai, os mesmos serão detalhados a seguir.

- Elementos de tensionamento

Os elementos de tensionamento de uma ponte estaiada são responsáveis pela suspensão das cargas do tabuleiro até os mastros. Estes elementos podem ser formados por um conjunto de barras ou cordoalhas, que formam os estais.

$\mathrm{Na}$ solução com barras rígidas, ao invés de fios, os estais podem ser compostos por barras únicas ou diversas barras paralelas entre si. Um exemplo de 
aplicação desta solução é a passarela estaiada da Universidade Federal de Alagoas, em Maceió.

Porém a utilização de cordoalhas, ao invés de barras rígidas, tem sido a solução mais bem aceita e adotada. As cordoalhas são compostas por um feixe de fios, que são dispostos circundando um núcleo central em uma ou mais camadas.

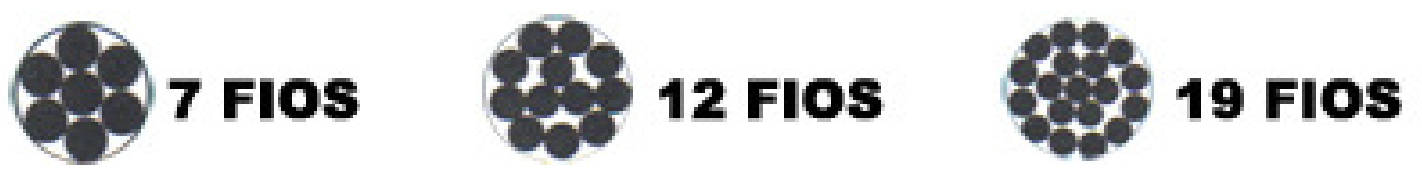

Figura 2.8 - Exemplos de seção de cordoalhas

Já os estais, neste caso, são constituídos pela composição de diversas cordoalhas dispostas helicoidalmente, obtendo-se o seu diâmetro de acordo com a necessidade de projeto, sendo a cordoalha mais usual em estais a de sete fios.

- Sistemas de ancoragem

Existem diversos tipos de ancoragem dos estais, variando de acordo com a tecnologia que cada empresa utiliza. De maneira geral os sistemas de ancoragem devem ser capazes de realizar ajustes ao longo da execução da ponte, com o intuito de manter as tensões e o nivelamento dos estais e tabuleiro, e também de permitir uma manutenção e troca dos estais.

Tendo em vista esta capacidade de realizar ajustes nos sistemas de ancoragem, pode-se obter um isoalongamento dos estais, evitando que um menos alongado receba mais carga que outro mais alongado, garantindo um melhor funcionamento do conjunto. 


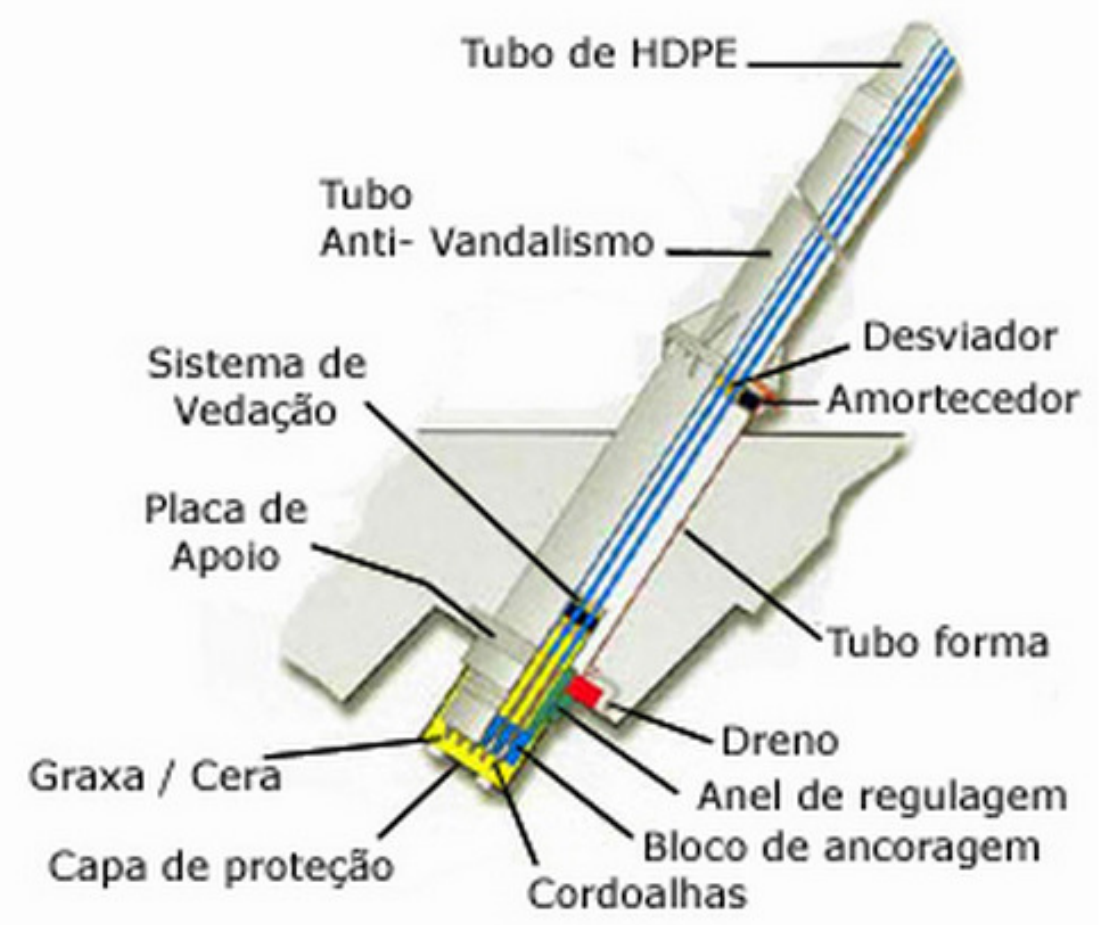

Figura 2.9 - Sistema de ancoragem e proteção de um estai (http://www.protende.com.br/newsite/tabelas/tipoestais.htm)

- Sistemas de proteção

A proteção mais largamente utilizada nos estais são tubos de polietileno de elevada resistência mecânica, resistentes à ação de raios ultravioleta, com a função de proteger o aço contra corrosão e efeitos do tempo. Esta proteção também é muito explorada do ponto de vista estético, utilizando cores de acordo com o idealizado do projeto arquitetônico.

Além desse sistema de encapamento, ainda há a opção de galvanização das cordoalhas, mantendo-as expostas.

Outra proteção largamente usada é o tubo anti-vandalismo, que consiste em um tubo de aço de elevada resistência utilizado até uma altura suficiente para que os estais não sofram com a ação de vândalos.

Atualmente, esse conjunto de tecnologias nos aparelhos de ancoragem e nos sistemas de proteção dos estais, contribui para que os mesmos sejam mais duráveis e econômicos. 
Os estais de uma ponte estaiada podem ser dispostos de inúmeras maneiras, sendo que esta distribuição será responsável pela definição do seu desempenho estrutural, do custo de execução e projeto, da rigidez das peças e da metodologia construtiva.

As geometrias mais comuns e mais aceitas são as seguintes:

a) Distribuição Transversal dos Cabos

A distribuição transversal dos cabos pode se dar de diversas maneiras, cada uma com suas vantagens e desvantagens, sejam elas visuais ou estruturais. A seguir será feita a análise das geometrias clássicas mais utilizadas atualmente.

- Um plano vertical central (único):

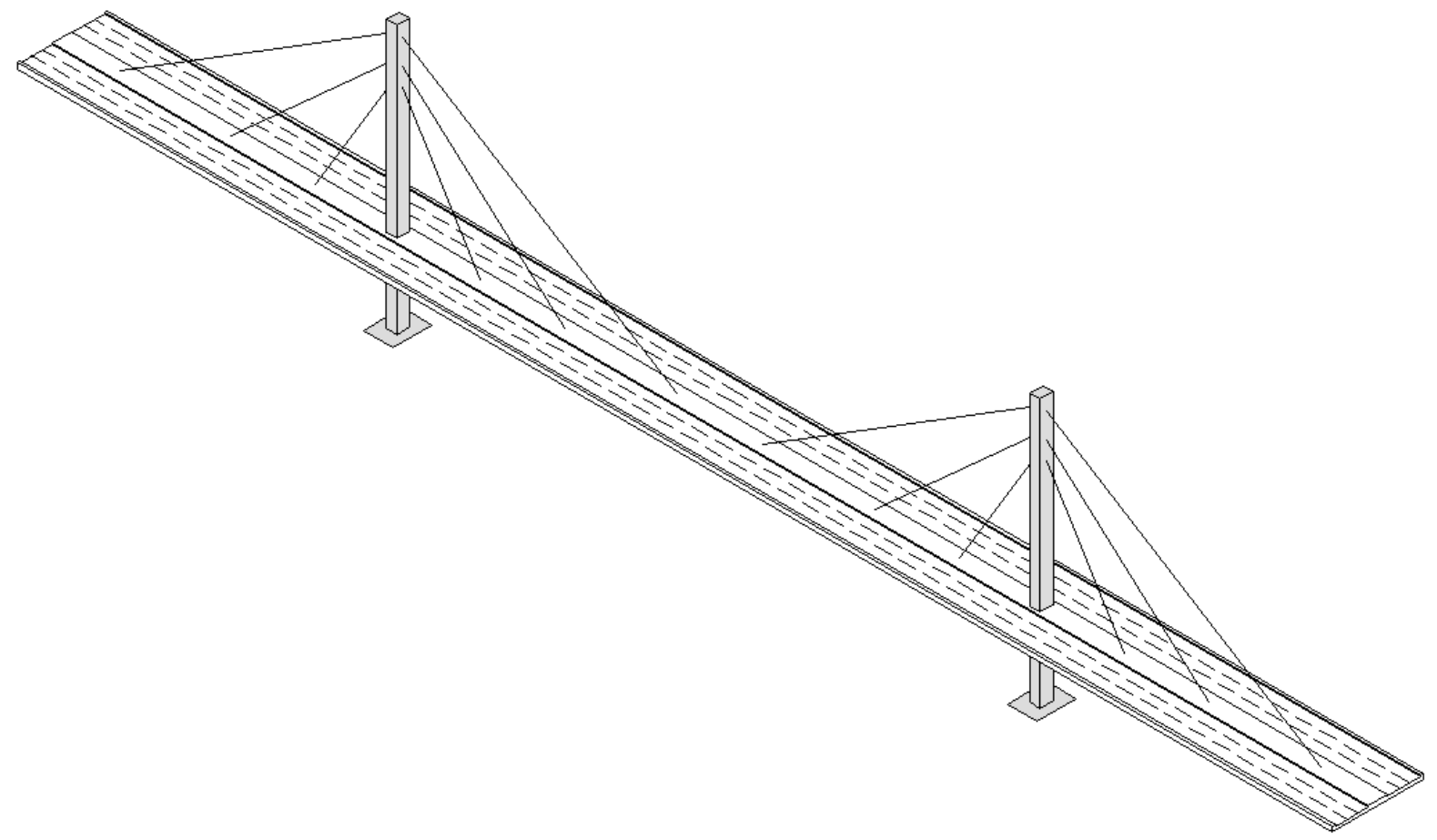

Figura 2.10 - Distribuição em um plano vertical

À primeira vista, as pontes com um plano central de cabos mostram-se estruturas muito limpas e esbeltas. Porém do ponto de vista estrutural esta solução é 
menos vantajosa, uma vez que os efeitos de torção e de estabilidade ficam dependentes da rigidez do tabuleiro.

Como a suspensão do tabuleiro é feita apenas pelo seu apoio central, quando há a aplicação de cargas acidentais assimétricas no tabuleiro, conforme mostrado na figura 2.11, surgem na estruturas esforços de torção consideráveis. Esses efeitos são resistidos pelo tabuleiro e pelos apoios nos mastros e aproximações da ponte.

Neste tipo de geometria a carga resistida pelos estais é grande, tendo em vista que a carga é resistida apenas por um plano de suspensão, com isso os estais e ancoragens são mais pesados, de maior diâmetro e mais caros.

Sendo assim, quando se tem a necessidade de tabuleiros mais largos, convém que se utilizem dois planos de suspensão, reduzindo a carga resistida pelos estais e os efeitos de torção do tabuleiro.

Mesmo com essa limitação, não há como negar que esta configuração apresenta uma ponte sensivelmente esbelta e agradável aos olhos, principalmente quando o tabuleiro e os pilares se apresentam como estruturas esbeltas.

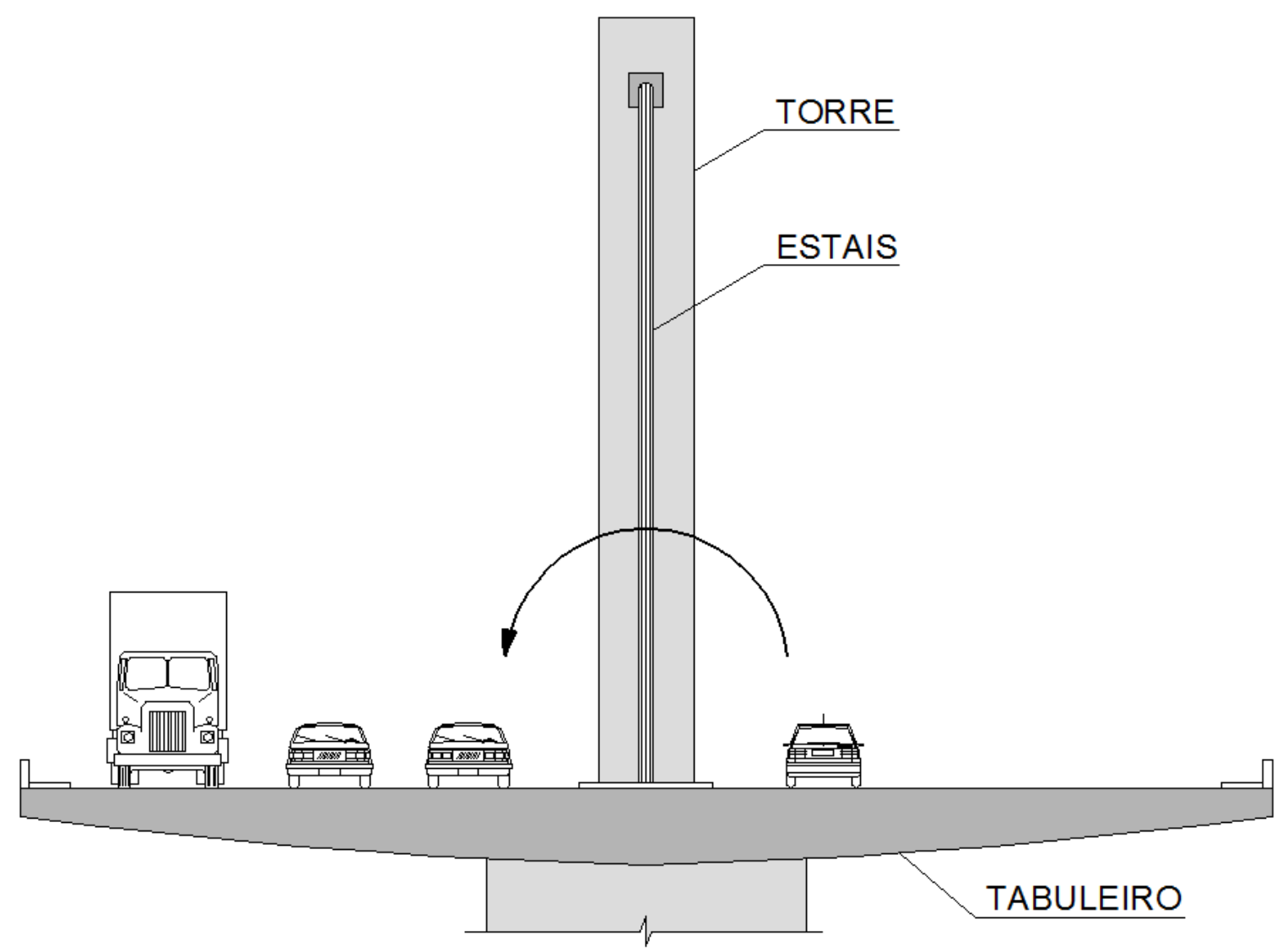

Figura 2.11 - Efeito de torção na distribuição de estais em um plano vertical 
Outro ponto importante deste tipo geometria é a passagem da torre pelo centro do tabuleiro. Quando os vãos são pequenos, essa interferência não é relevante, porém, quando os vãos são elevados essa interferência é significativa, uma vez que as dimensões da torre estão diretamente ligadas ao vão a ser transposto. Nestes casos, pode-se usar torres bipartidas na base, a fim de evitar as interferências com o tabuleiro. Este tipo de solução pode ser visto na ponte Brotonne, na França (figura 2.12)

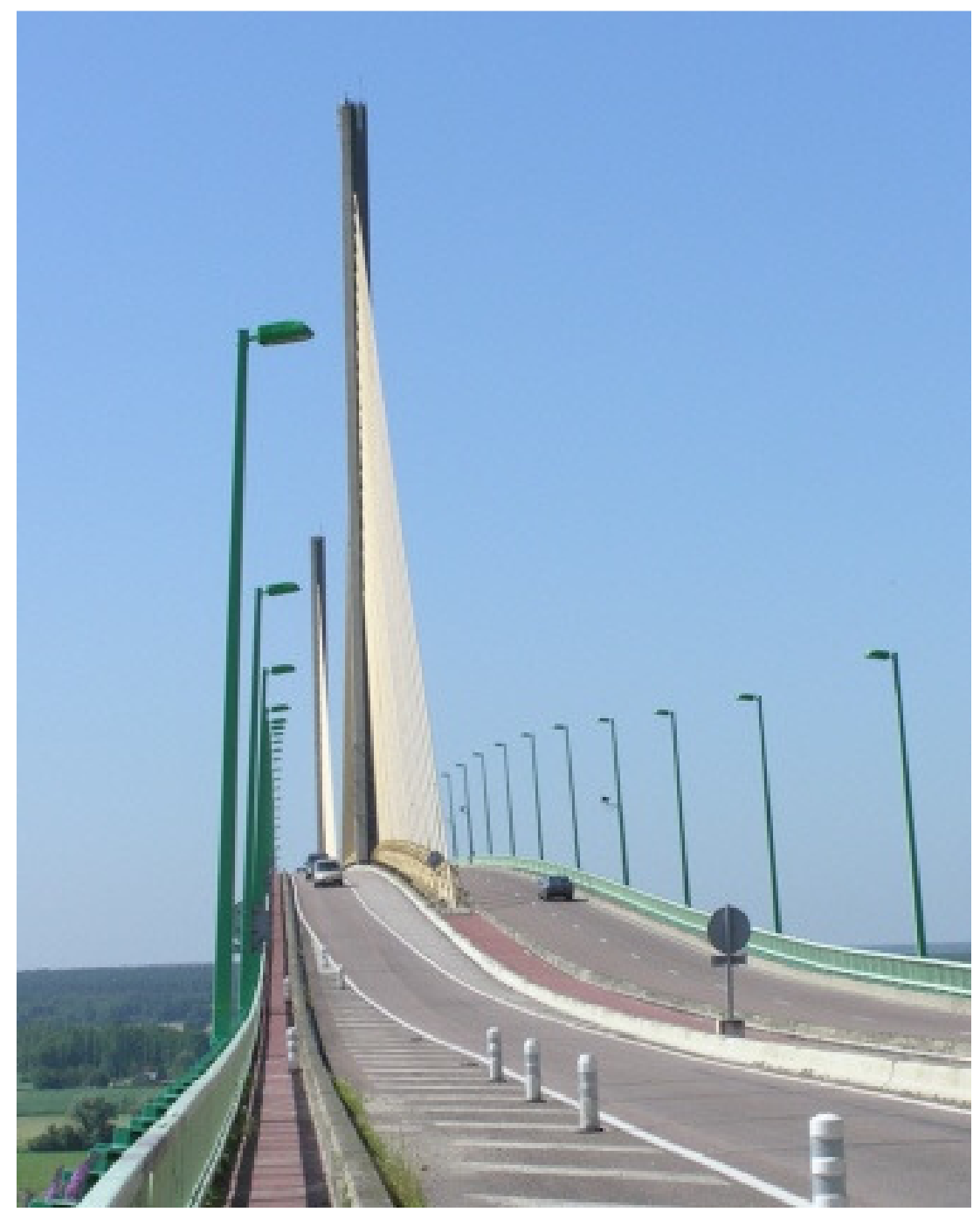

Figura 2.12 - Ponte Brotonne, na França (http://en.structurae.de/photos/index.cfm?JS=154764) 
- Dois planos verticais de apoio:

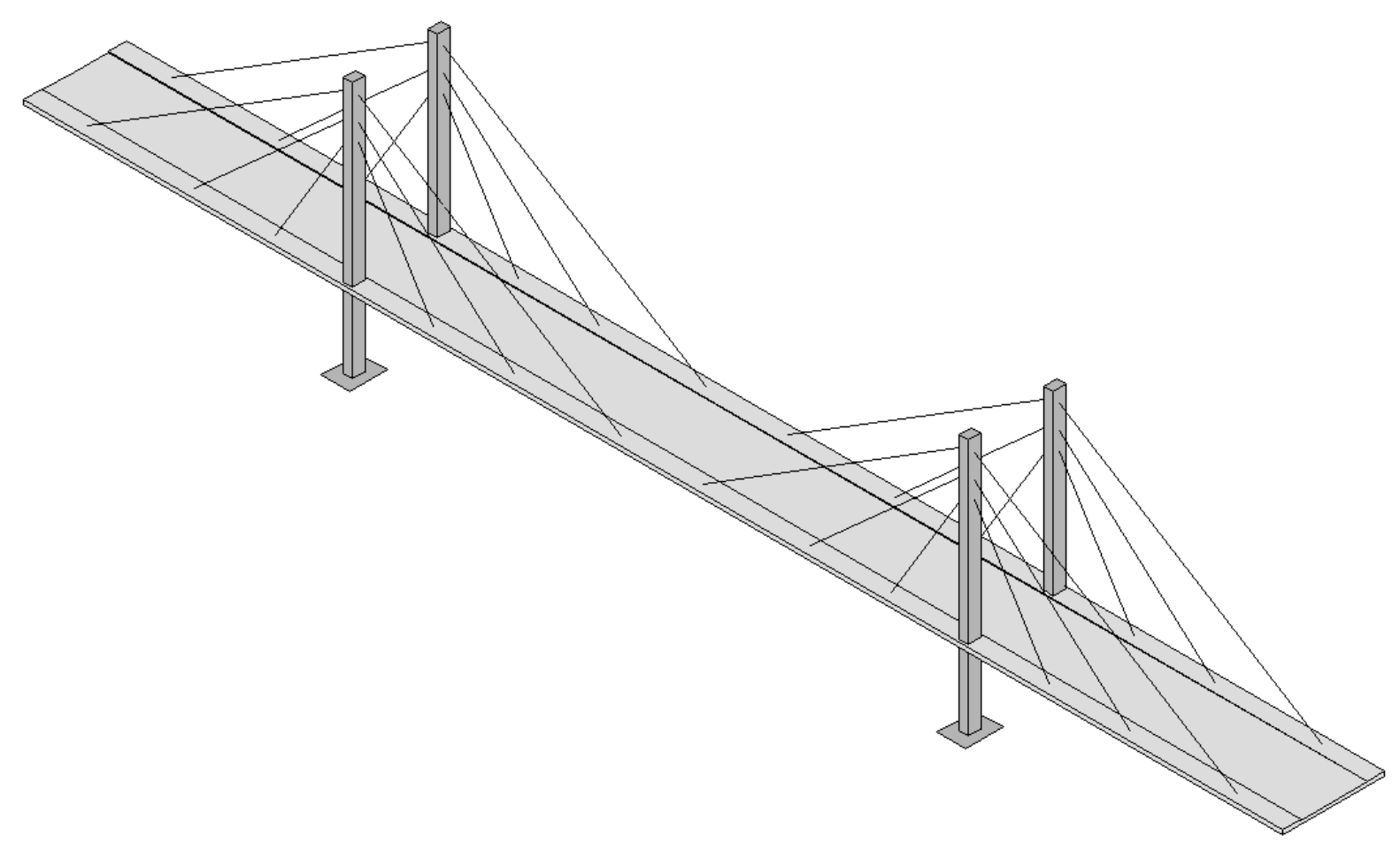

Figura 2.13 - Distribuição em dois planos verticais

Esta solução é mais interessante quando os tabuleiros da ponte são mais largos, uma vez que o efeito de torção não é expressivo como na solução anterior. Com isso, esta solução vem sendo largamente utilizada nos locais onde se necessita de mais faixas de rodagem para o tráfego na ponte.

Outra vantagem desta geometria é a possibilidade de posicionar os mastros pelo lado de fora do tabuleiro, evitando uma possível interferência do mastro com as faixas de rodagem.

Nesta geometria, o sentido principal de trabalho do tabuleiro é o transversal, podendo ser comparado a uma laje bi apoiada. Sendo assim, o esforço predominante será a flexão transversal do tabuleiro, e não a torção.

No caso da utilização de tabuleiros largos, pode-se utilizar o sistema de protensão transversal para reduzir os efeitos da flexão e, consequentemente, utilizar tabuleiros mais leves e esbeltos. 


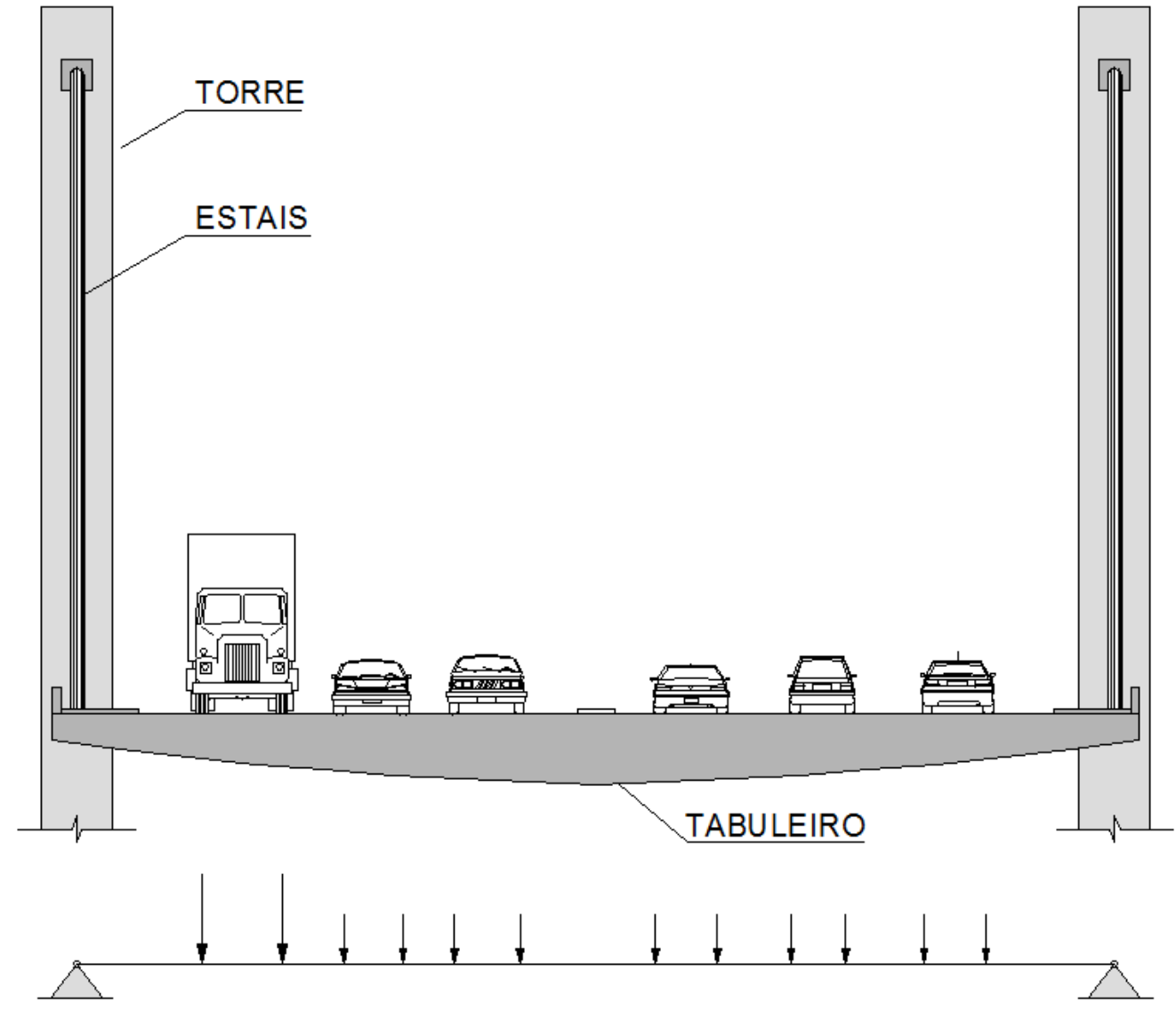

Figura 2.14 - Esquema de cargas para pontes com dois planos verticais

- Três planos verticais de apoio:

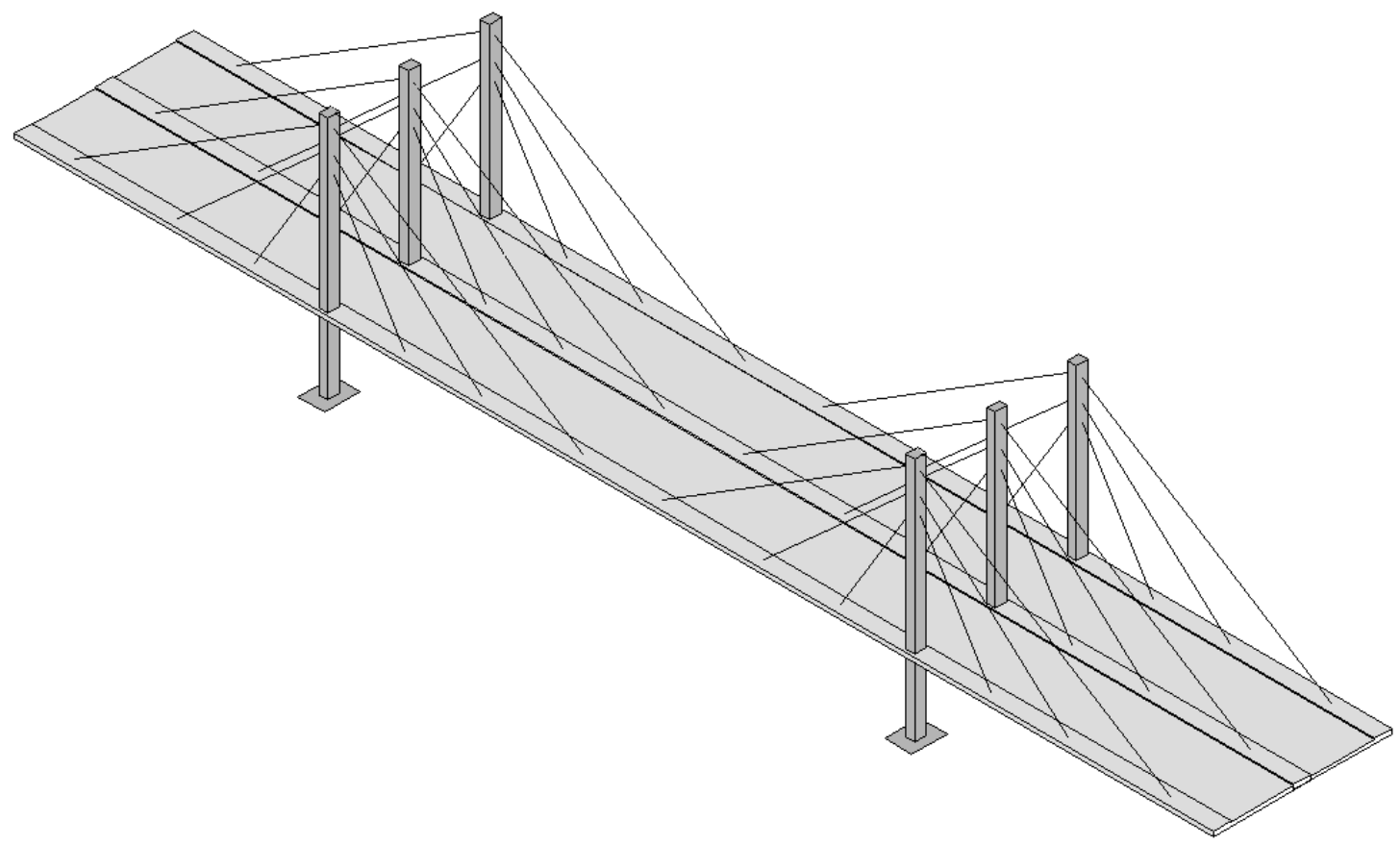

Figura 2.15 - Distribuição em três planos verticais 
Teoricamente, podem ser utilizados três ou mais planos de suspensão, porém este tipo de alternativa é uma solução mais teórica, e sua utilização pouco divulgada e conhecida. Esta geometria se mostraria mais adequada nos casos onde existem tabuleiros muito largos, associados a carregamentos elevados atuando na estrutura, porém esta situação hipotética também ocorre raramente. Além disso, existem novas técnicas construtivas e novas tecnologias que permitem que tabuleiros com menos apoios sejam também capazes de resistir a elevadas cargas;

- Dois planos inclinados de apoio

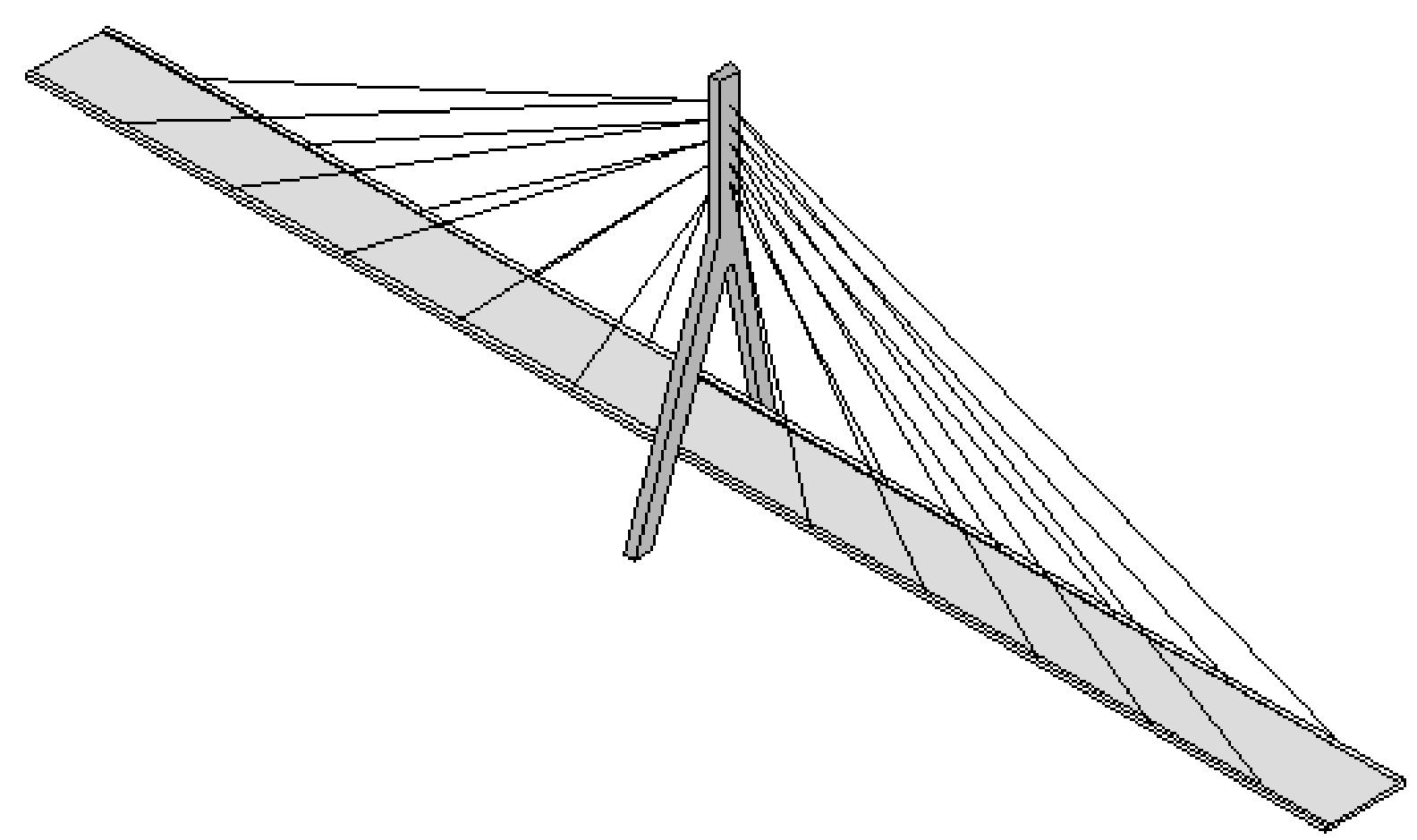

Figura 2.16 - Distribuição em dois planos inclinados

A utilização de torres com a geometria de $\mathrm{A}$, ligando as duas partes em uma única parte superior, é vantajosa pela não interferência das torres com o tabuleiro. Do ponto de vista estético, esta solução se mostra bem agradável.

Uma desvantagem deste sistema é a possível interferência dos cabos com o gabarito rodoviário da ponte. Este tipo de interferência ocorre devido à inclinação dos cabos em relação ao tabuleiro. 
Este tipo de interferência se mostra mais claro e evidente em pontes com dimensões mais reduzidas, e principalmente quando os pilares são baixos, forçando mais ainda uma inclinação indesejada dos estais. As interferências deste tipo podem ser reduzidas fazendo com que os pontos de ancoragem sejam externos ao tabuleiro, através de mecanismos de fixação, ou então alargando o tabuleiro a fim de levar os cabos o mais afastado possível da faixa de rolagem da via, ou até mesmo pela utilização de passeios mais largos.

As interferências dos estais com o gabarito podem ser ainda mais criticas no caso de tabuleiros curvos, uma vez que a inclinação dos estais é mais desfavorável.

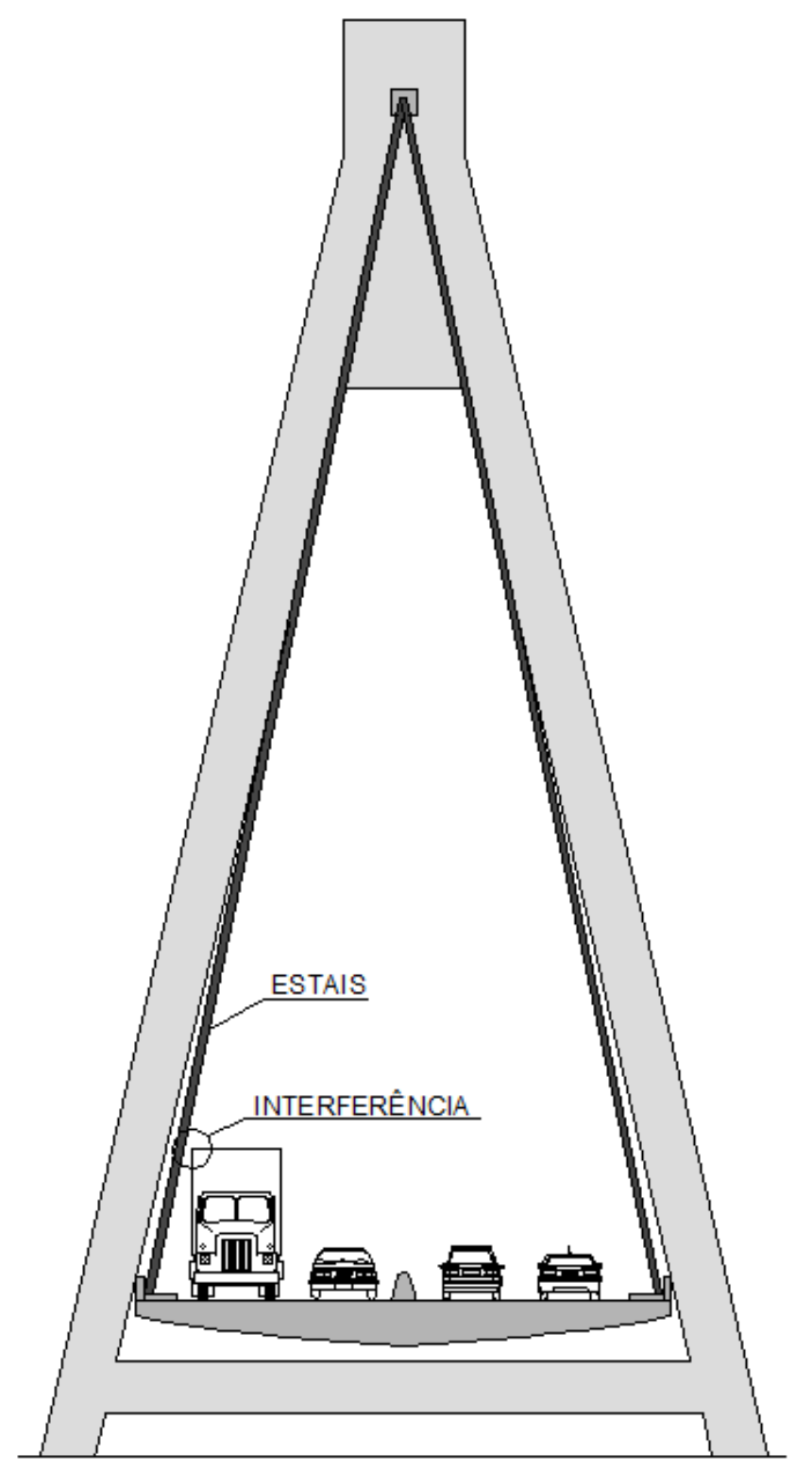

Figura 2.17 - Interferência dos estais no gabarito da via 
b) Distribuição Longitudinal dos Cabos

Os cabos podem ser dispostos longitudinalmente de diversas maneiras, de acordo com as necessidades do projeto ou devido a um efeito visual buscado. As geometrias mais difundidas as seguintes:

- Harpa:

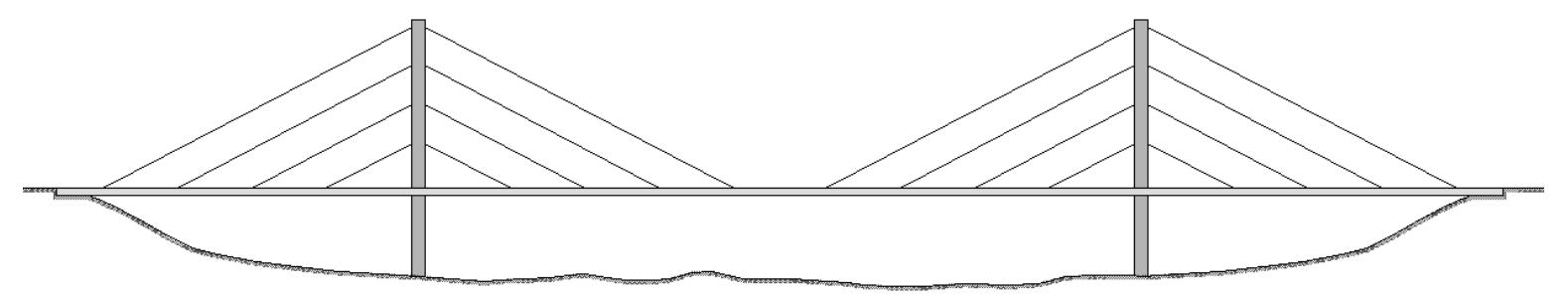

Figura 2.18 - Geometria em Harpa

$\mathrm{Na}$ geometria em harpa os cabos são ancorados nos pilares utilizando-se espaçamentos iguais entre os mesmos. Além disso, os cabos são paralelos entre si.

Esta solução é a mais aceita no ponto de vista da estética, pelo fato de produzir um visual agradável aos olhos da grande maioria dos profissionais da área e da população em geral. Devido a esse fato, inúmeras pontes foram concebidas desta maneira, mesmo não sendo a geometria mais eficiente, uma vez que quanto maior a inclinação dos estais, menor a sua eficiência.

Para os carregamentos permanentes, as forças verticais são encaminhadas para a fundação e os esforços horizontais atuando no mastro ficam balanceados, conforme mostrado abaixo:

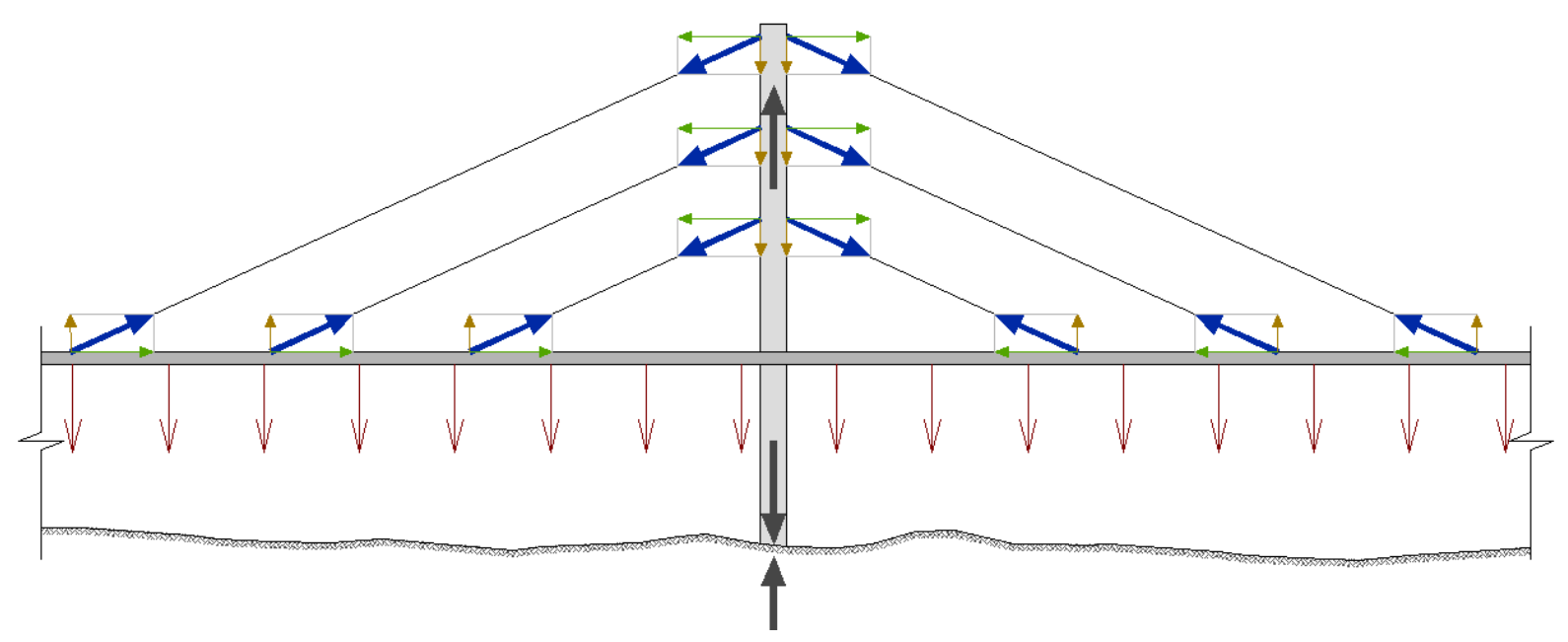

Figura 2.19 - Forças atuantes na geometria em harpa 
Uma desvantagem desta geometria surge muito claramente quando temos cargas assimétricas, que introduzem esforços horizontais nos pilares. Com isso, estes deverão ter rigidez suficiente para resistir a estes esforços, tornando-os mais robustos que em outras geometrias.

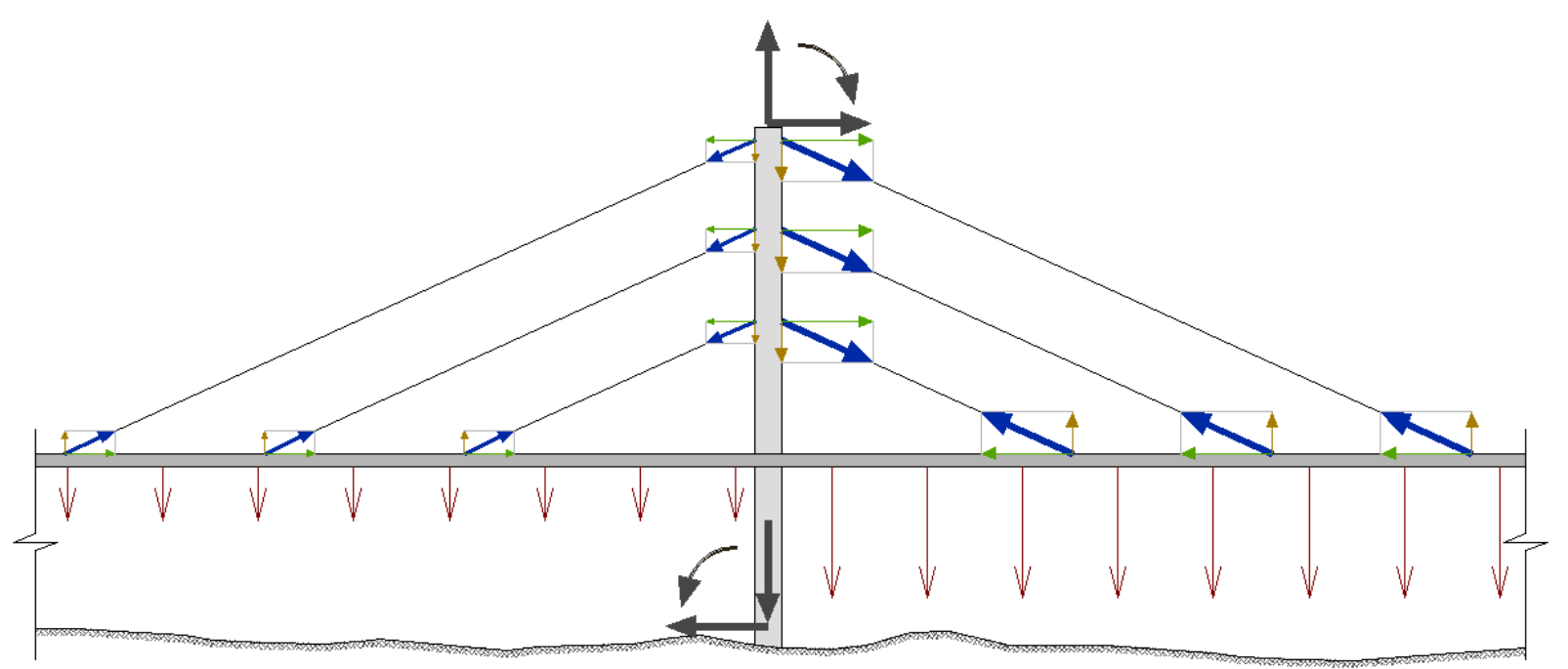

Figura 2.20 - Forças assimétricas atuantes na geometria em harpa

- Leque:

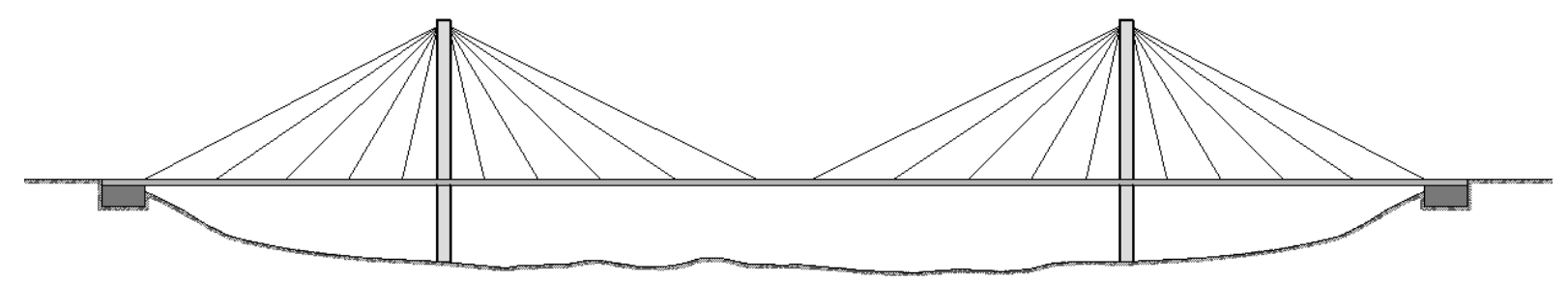

Figura 2.21 - Geometria em Leque

Nesta concepção os estais são fixos no topo dos pilares, propiciando os seguintes benefícios para a estrutura:

- Os esforços horizontais introduzidos no tabuleiro pelos estais são reduzidos, uma vez que há uma maior verticalidade dos mesmos, evitando acúmulos de tensões nas ancoragens no tabuleiro.

- A flexibilidade da estrutura é muito útil nos casos de movimentações horizontais, gerando um ganho considerável de estabilidade no caso de efeitos sísmicos. 
- A flexão dos mastros não é tão elevada quanto no sistema em harpa, uma vez que os cabos chegam mais verticalmente, introduzindo esforços horizontais menores.

- Tendo em vista que o espaçamento dos estais é reduzido, a carga resistida por cada um também é reduzida, podendo ser utilizados estais de pequenos diâmetros, que ajudam muito no efeito estético de transparência.

Porém esta geometria também apresenta algumas desvantagens. Primeiramente vale a pena destacar o emaranhado de cabos no topo dos pilares, que apresentam uma visual menos leve que o sistema em harpa.

Outra desvantagem é o projeto e execução deste sistema de ancoragem dos cabos no topo do pilar, gerando uma grande complexidade, tanto no cálculo dos esforços atuando neste trecho, quanto na execução detalhada da ancoragem de cada cabo, elevando muito o custo deste tipo ancoragem. No Brasil este tipo de solução não é adotada justamente por essa complexidade e pelo custo.

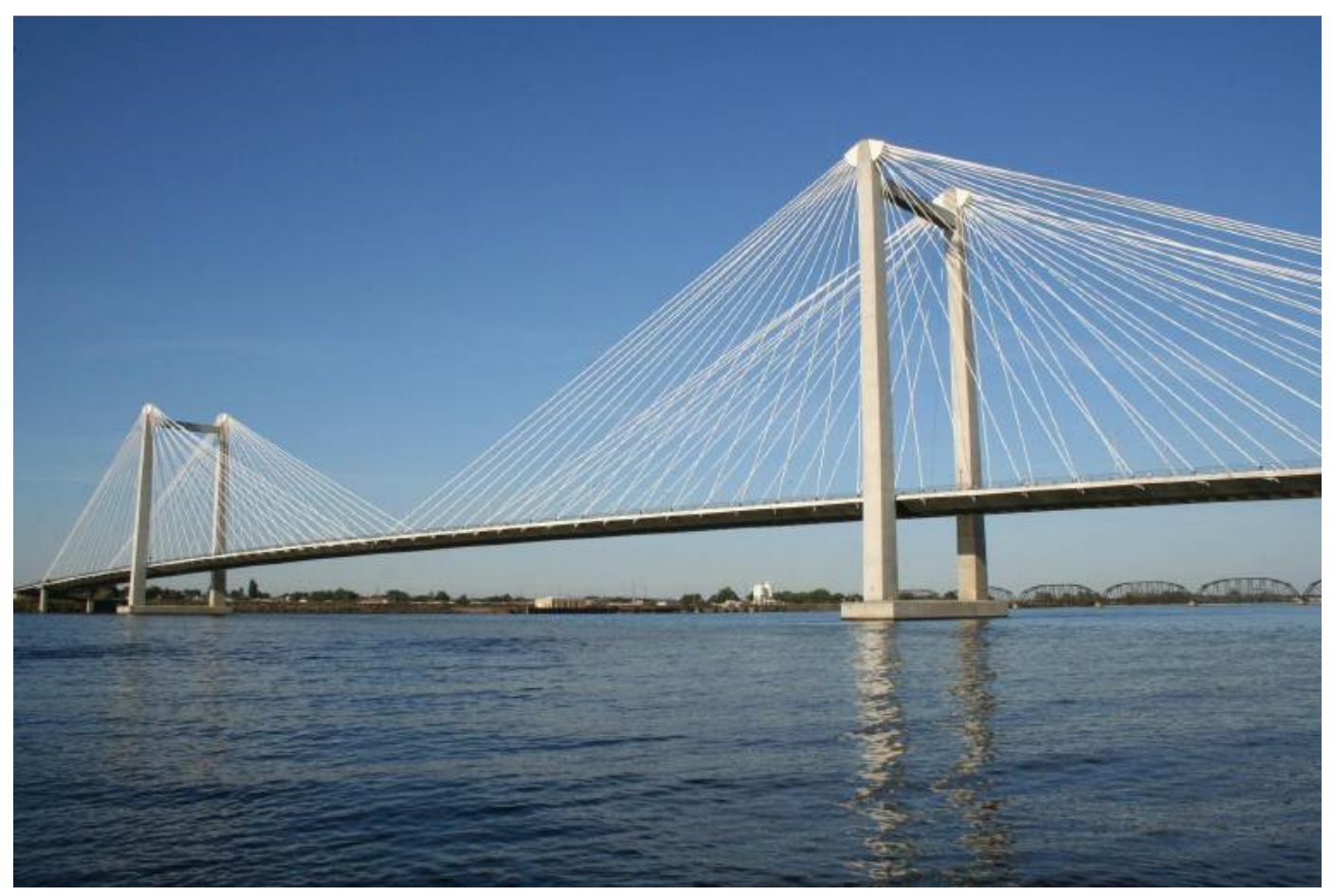

Figura 2.22 - Ponte em Leque - Pasco-Kennewick - EUA

(http://www.bridgemeister.com/pic.php?pid=1774) 
- Semi-Harpa:

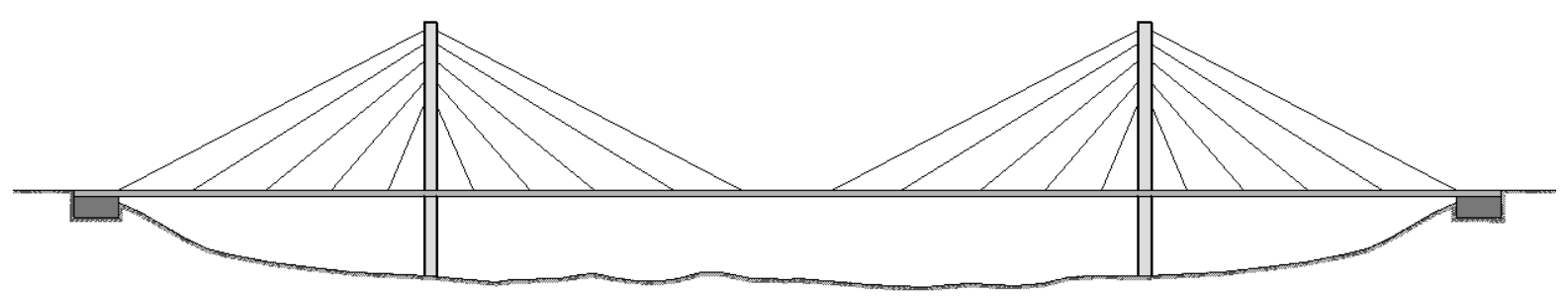

Figura 2.23 - Geometria Semi-Harpa

Esta concepção é uma solução intermediária entre a Harpa e o Leque, onde se faz proveito das melhores qualidades de cada sistema e, consequentemente, evitando as principais desvantagens de cada um. Com isso, esta solução tem se mostrado a mais ideal e mais difundida no mundo inteiro.

A distribuição das ancoragens ao longo do pilar faz com que estas ligações se tornem menos complexa que na geometria em leque. Além disso, a inclinação variável dos cabos faz com que os esforços horizontais aplicados no tabuleiro sejam menores, bem próximos aos da geometria em leque.

Um exemplo deste sistema é a Ponte sobre o rio Paranaíba, na divisa dos estados de Mato Grosso e Minas Gerais - Brasil (Figura 2.24).

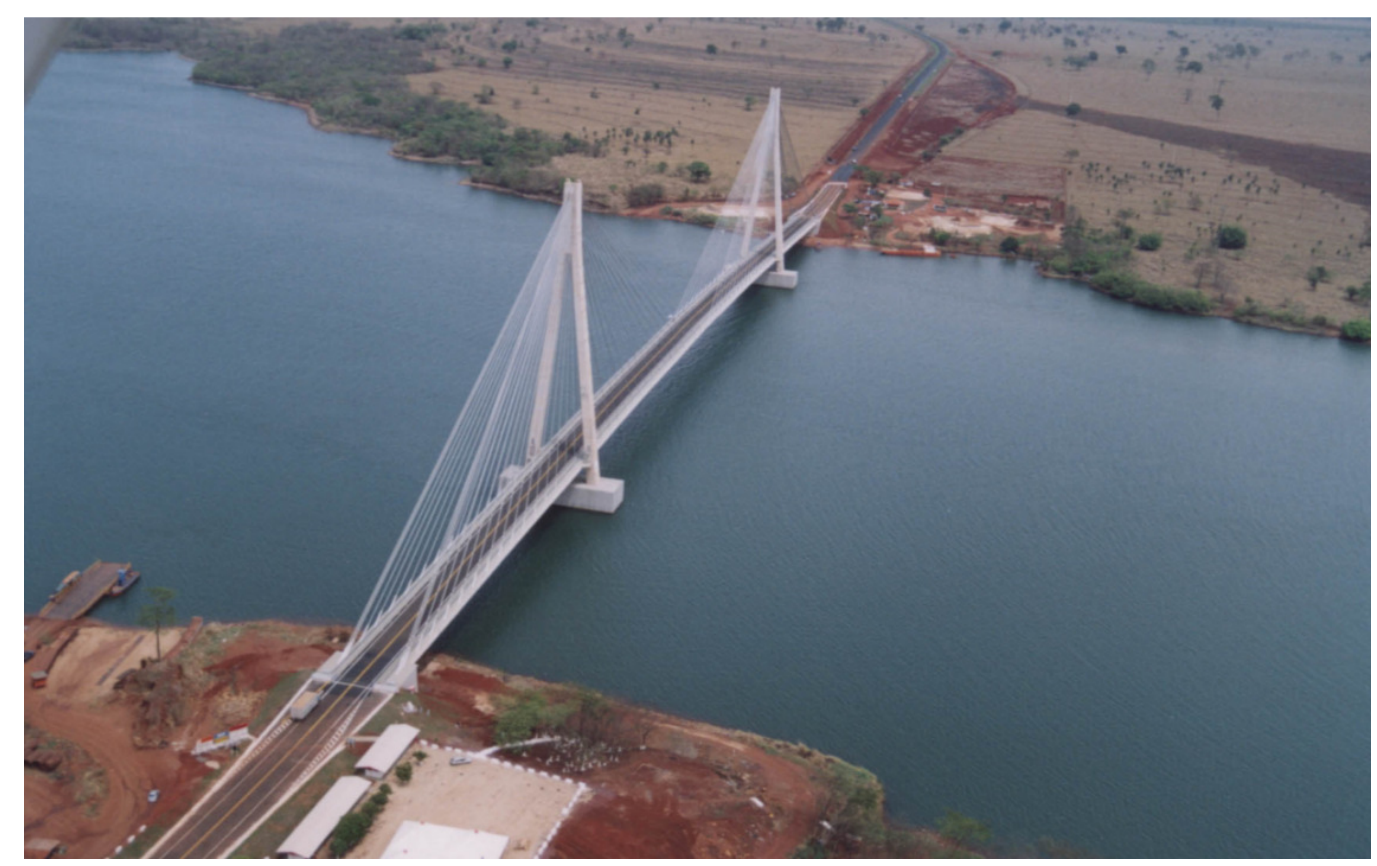

Figura 2.24 - Geometria de Semi-Harpa da Ponte sobre o Rio Paranaíba (http://www.proparnaiba.com/redacao/cidades-saiba-quais-s-o-parna-bas-do-brasil.html) 
- Assimétrica:

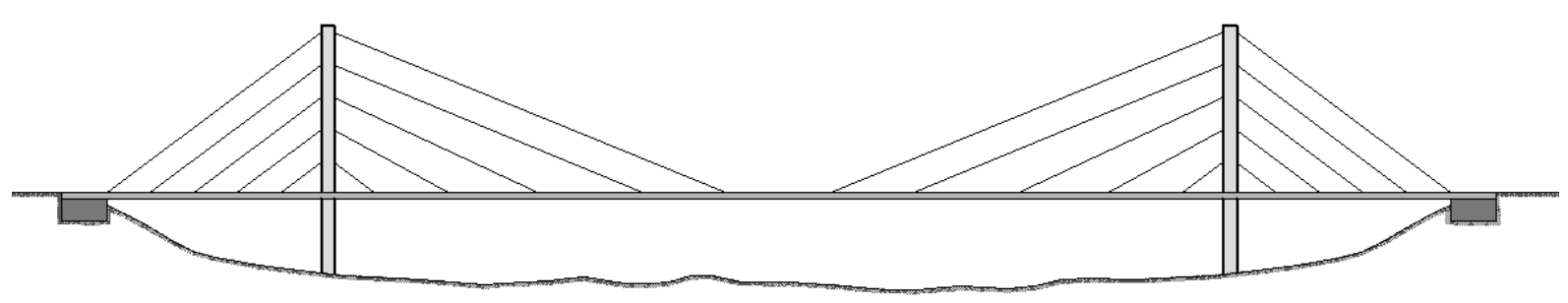

Figura 2.25 - Geometria Assimétrica

Esta solução é muito útil quando as condições topográficas, ou interferências no meio, não permitem que a estrutura tenha seus carregamentos permanentes auto-equilibrados em torno dos mastros. Com isso, faz-se necessário que os cabos fiquem ancorados em estruturas auxiliares, como, por exemplo, blocos de ancoragem.

Além disso, esta solução necessita de um tratamento estético, a fim de que os blocos de ancoragem dos cabos não destoem da estrutura que, de maneira geral, é esbelta e leve. Estes blocos, em sua grande maioria, são peças de concreto de grandes dimensões, de maneira que o seu peso próprio seja capaz de resistir aos esforços provenientes dos cabos.

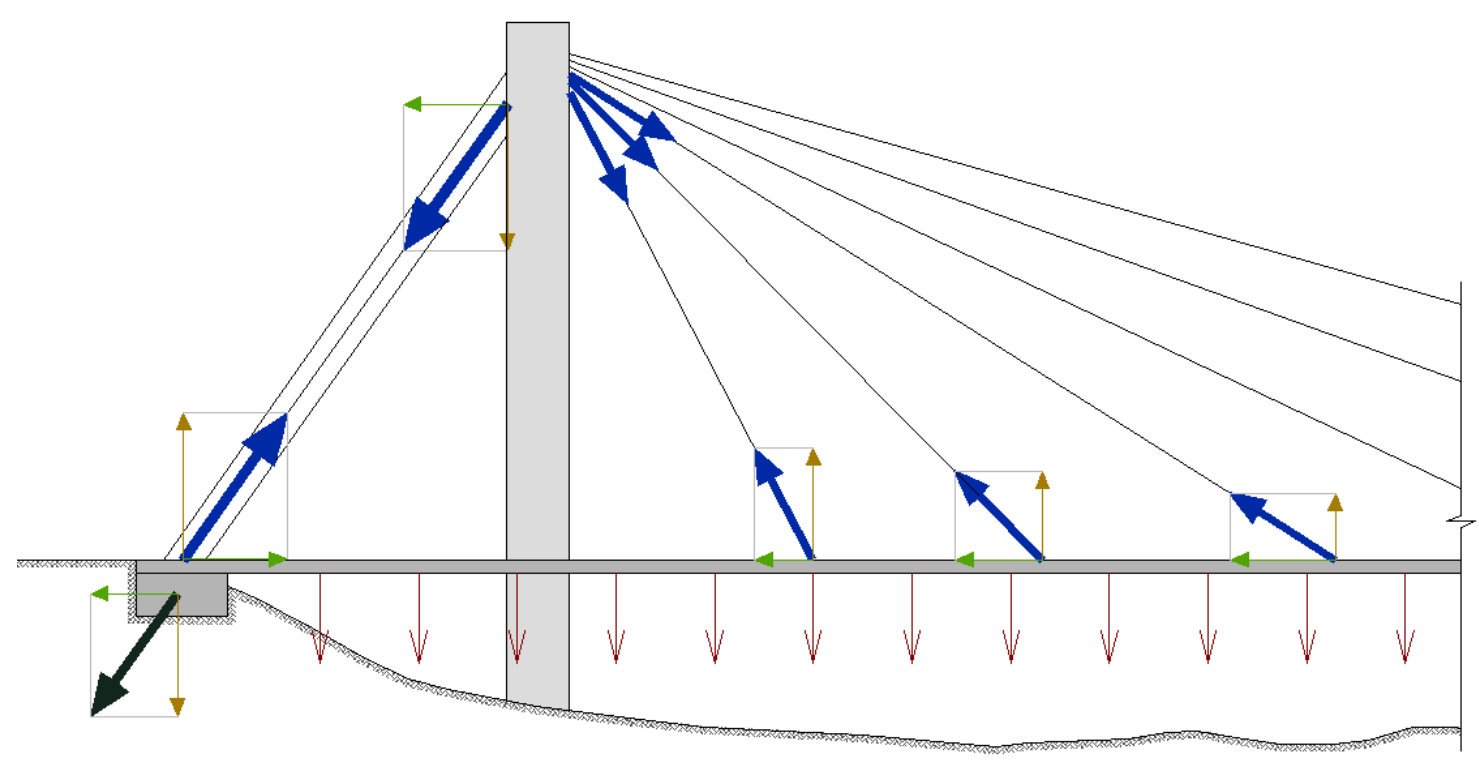

Figura 2.26 - Esquema de cargas para a geometria assimétrica

Além das geometrias demonstradas aqui existem diversas outras mais arrojadas e criativas, que são geradas pela contínua necessidade do ser humano de 
vencer os próprios limites e se superar. Um exemplo clássico de inovação é a ponte Octavio Frias de Oliveira, localizada em São Paulo, Brasil. Nesta ponte há a presença de dois tabuleiros curvos, de diferentes níveis altimétricos, sustentados por um único mastro central

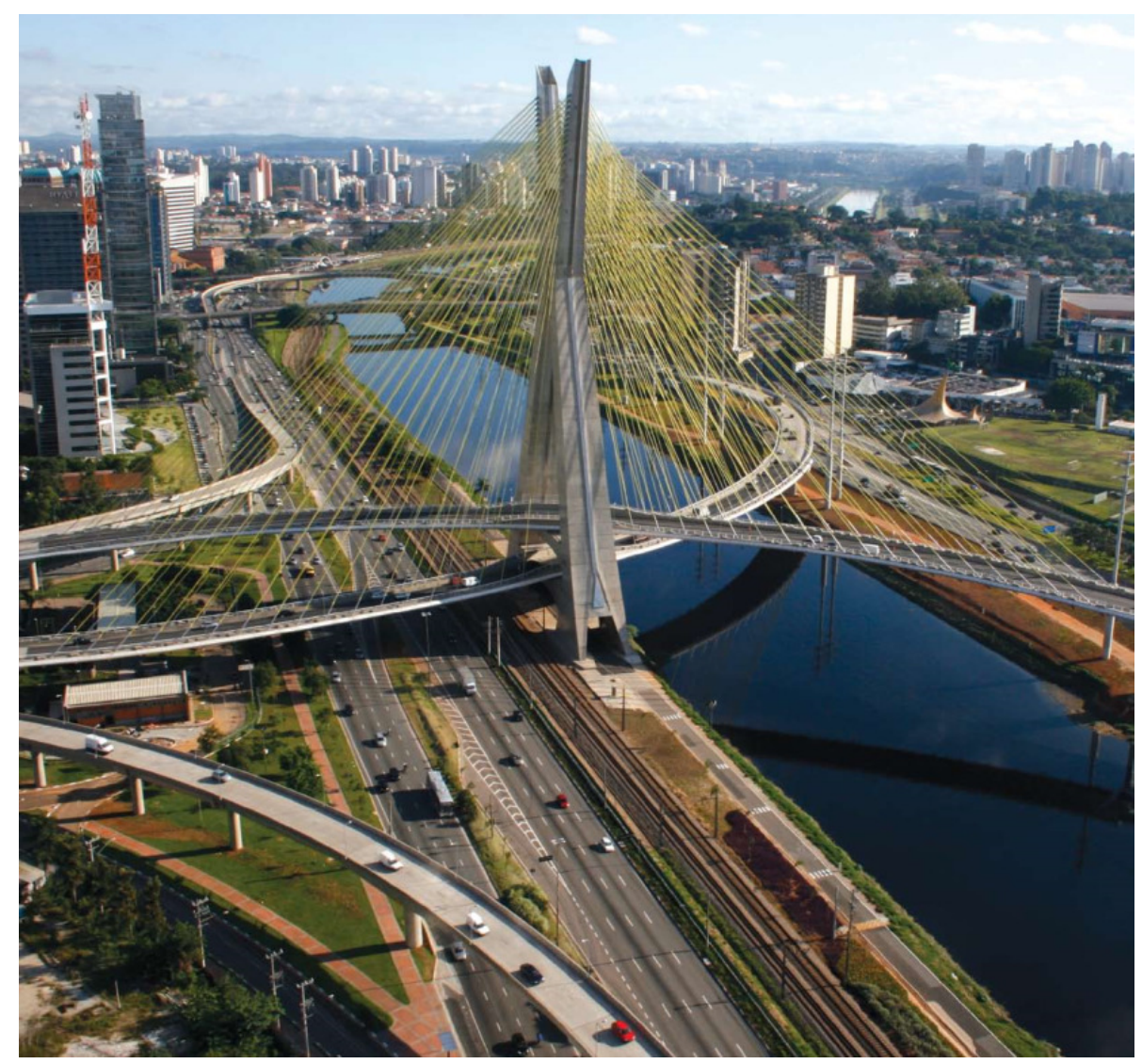

Figura 2.27 - Ponte Octavio Frias de Oliveira - São Paulo

(http://www.skyscrapercity.com/showthread.php?t=985446)

- Extradorso

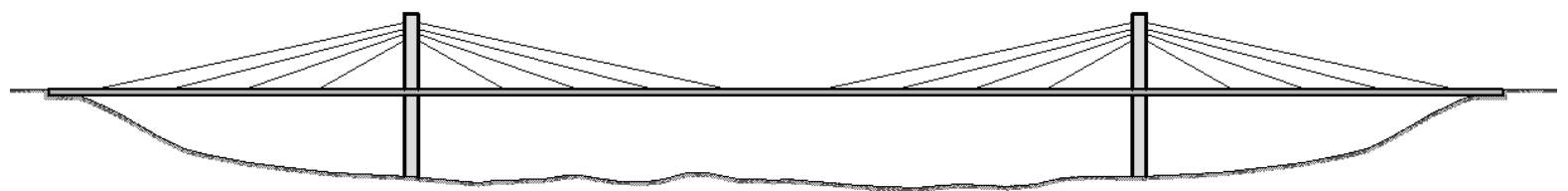

Figura 2.28 - Ponte estaiada extradorso

A ponte estaiada extradorso é uma mistura de uma ponte comum, com vigas, e uma ponte estaiada. Nesta geometria a torre é mais baixa que nas pontes 
estaiadas comuns, de maneira que os cabos cheguem ao tabuleiro em ângulos pequenos. Com isso, os esforços de compressão no tabuleiro são elevados.

As configurações longitudinal e transversal dos estais podem seguir as geometrias citadas anteriormente.

Este tipo de geometria é interessante quando se tem uma limitação na altura da torre a ser construída, devido a interferências com o local onde a mesma será executada.

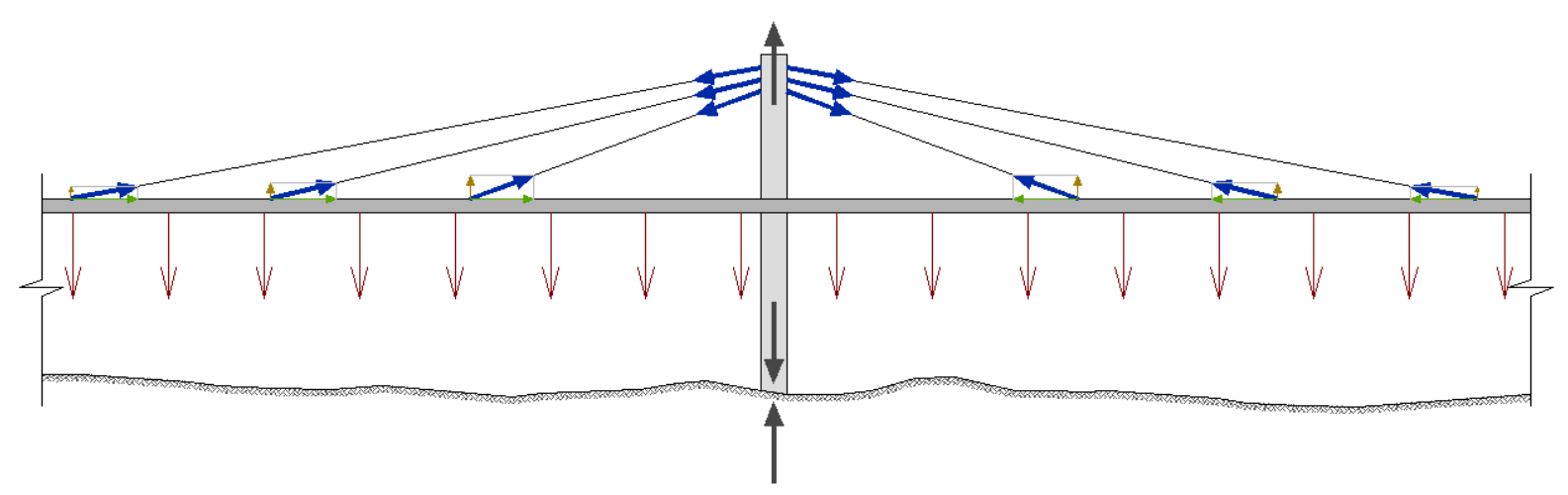

Figura 2.29 - Esforços na ponte estaiada extradorso

Como exemplo pode-se citar a ponte Odawara Blueway, que foi a primeira ponte extradorso construída. Finalizada em 1994 no Japão, esta ponte possui um vão principal de $122 \mathrm{~m}$ e comprimento total de $270 \mathrm{~m}$. O tabuleiro de concreto protendido possui 16,2 m de largura e espessura variável de 2,2 m a 3,5 m. As torres possuem apenas 10,7 $\mathrm{m}$ acima do tabuleiro, o que mostra como este tipo de ponte possui torres muito menores que nas demais pontes estaiadas.

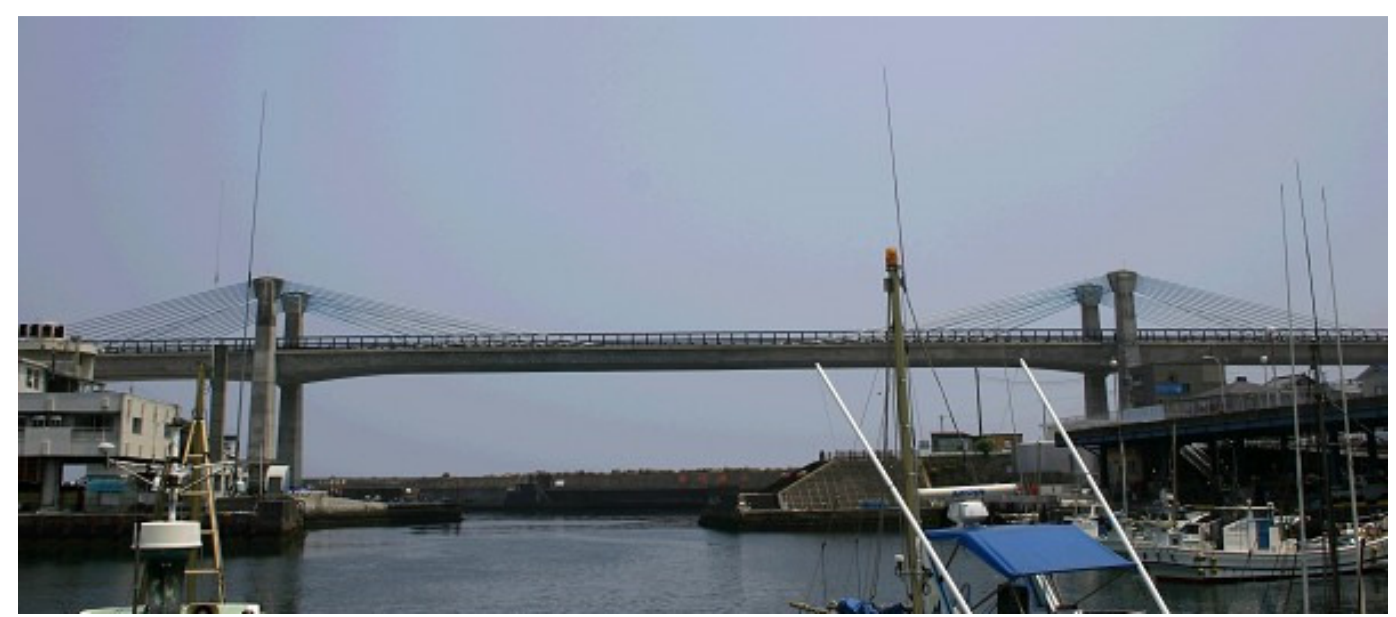

Figura 2.30 - Ponte Odawara Blueway (http://en.structurae.info/photos/index.cfm?JS=41476) 
- Múltiplos vãos:

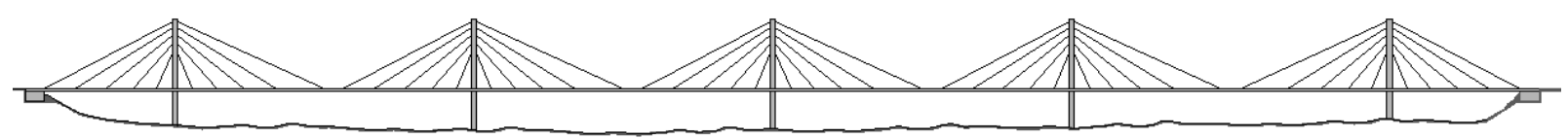

Figura 2.31 - Ponte estaiada com múltiplos vãos

Esta solução pode utilizar qualquer uma das geometrias descritas anteriormente, porém repetidas o número de vezes necessário para satisfazer aos objetivos propostos. Este tipo de ponte vem sendo largamente usado principalmente nas regiões onde se tem grandes vãos, tais como vales, rios e grandes montanhas.

Como exemplo, pode-se citar o Viaduto de Millau sobre o vale do Rio Tarn, próximo de Millau no sudoeste da França, sendo esta a ponte mais alta do mundo aberta ao tráfego de veículos, com 343 metros de altura.

Esta ponte foi projetada pelos engenheiros Benoit Lecinq e Michel Virlogeux, contando também com o projeto arquitetônico de Norman Robert Foster e com a consultoria técnica de Jean-Claude Foucriat, Jean Peccardi e François Schlosser.

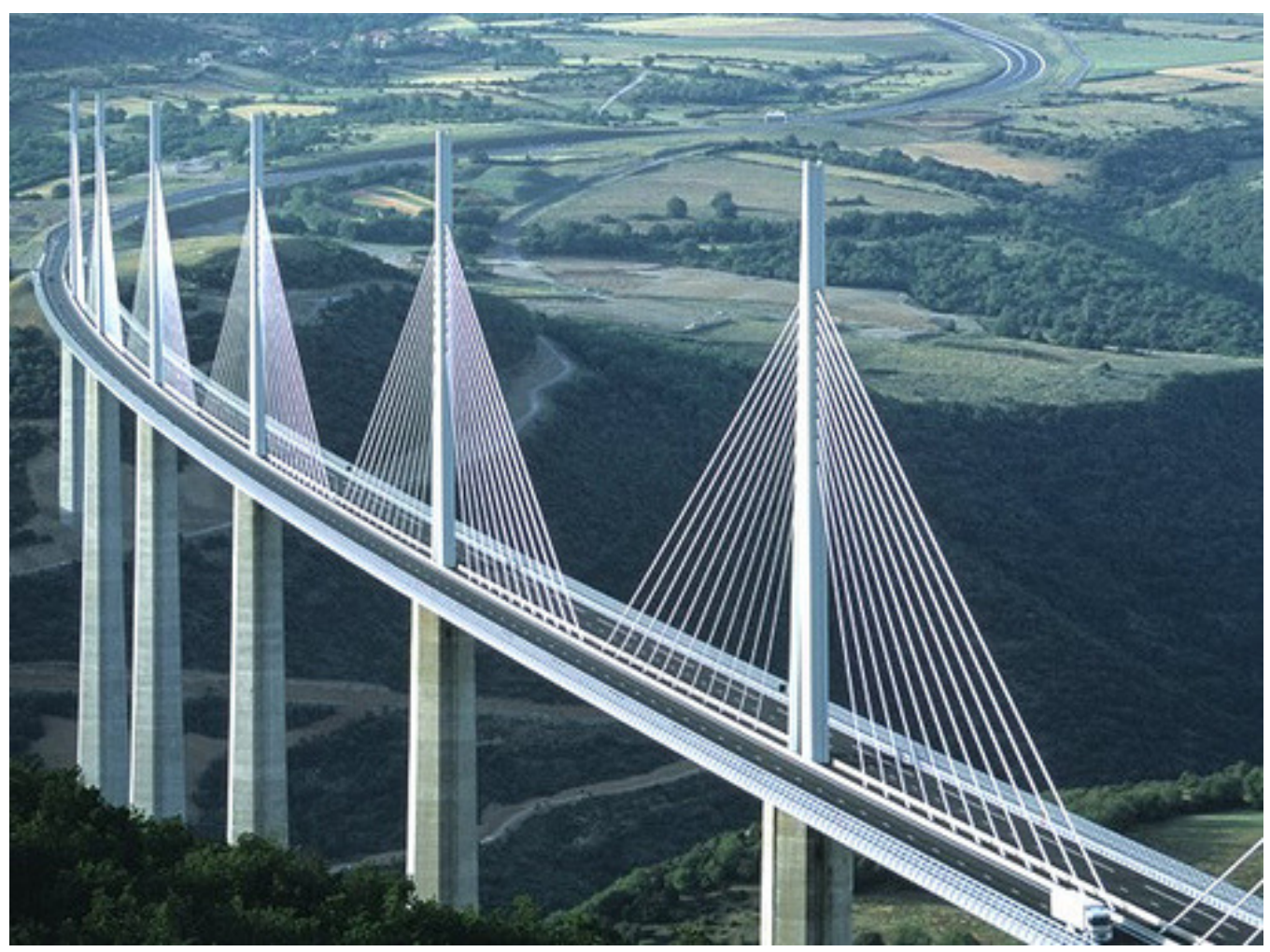

Figura 2.32 - Viaduto de Millau - França (http://www.flickr.com/photos/licerantola/2615219332) 
A ponte é constituída por oito trechos estaiados com tabuleiro metálico, apoiados sobre pilares de concreto que variam de 77 a $246 \mathrm{~m}$, com diâmetro variável de $24,5 \mathrm{~m}$ na base até $11 \mathrm{~m}$ no topo.

Sua construção foi iniciada em 10 de outubro de 2001 e só foi concluída em 14 de dezembro de 2004, além do prazo previsto em projeto, principalmente devido às dificuldades climáticas.

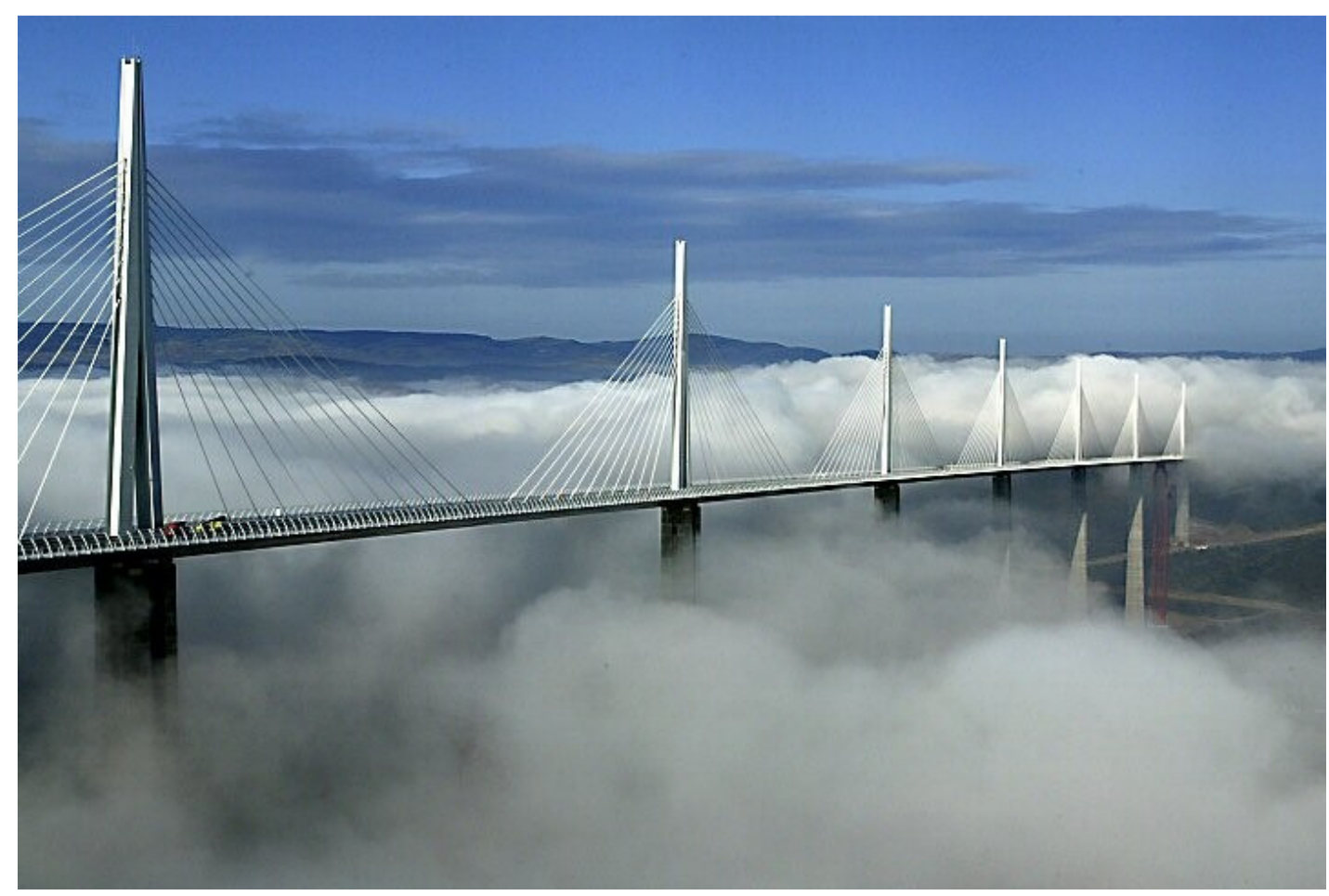

Figura 2.33 - Nuvens encobrindo o Viaduto de Millau - França (http://architetour.wordpress.com/2009/11/04/viaduto-de-millau/millau-3/)

O tabuleiro metálico foi executado nas margens da ponte e empurrado por macacos hidráulicos guiados por GPS, deslizando o tabuleiro sobre os pilares de concreto e os pilares metálicos provisórios. 


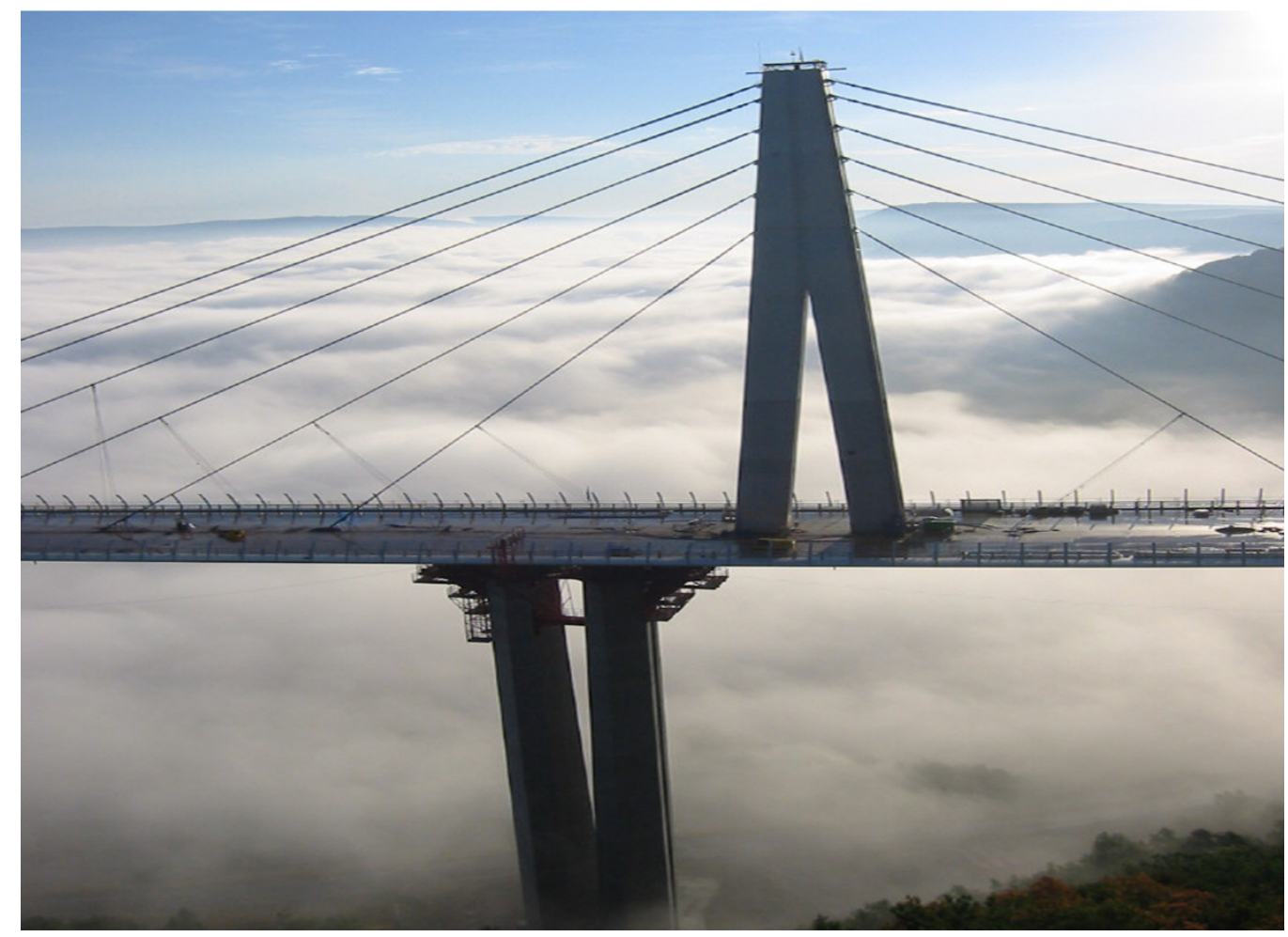

Figura 2.34 - Tabuleiro em execução (http://chuck.hubpages.com/hub/Millau_Viaduct_Worlds_Tallest_Bridge)

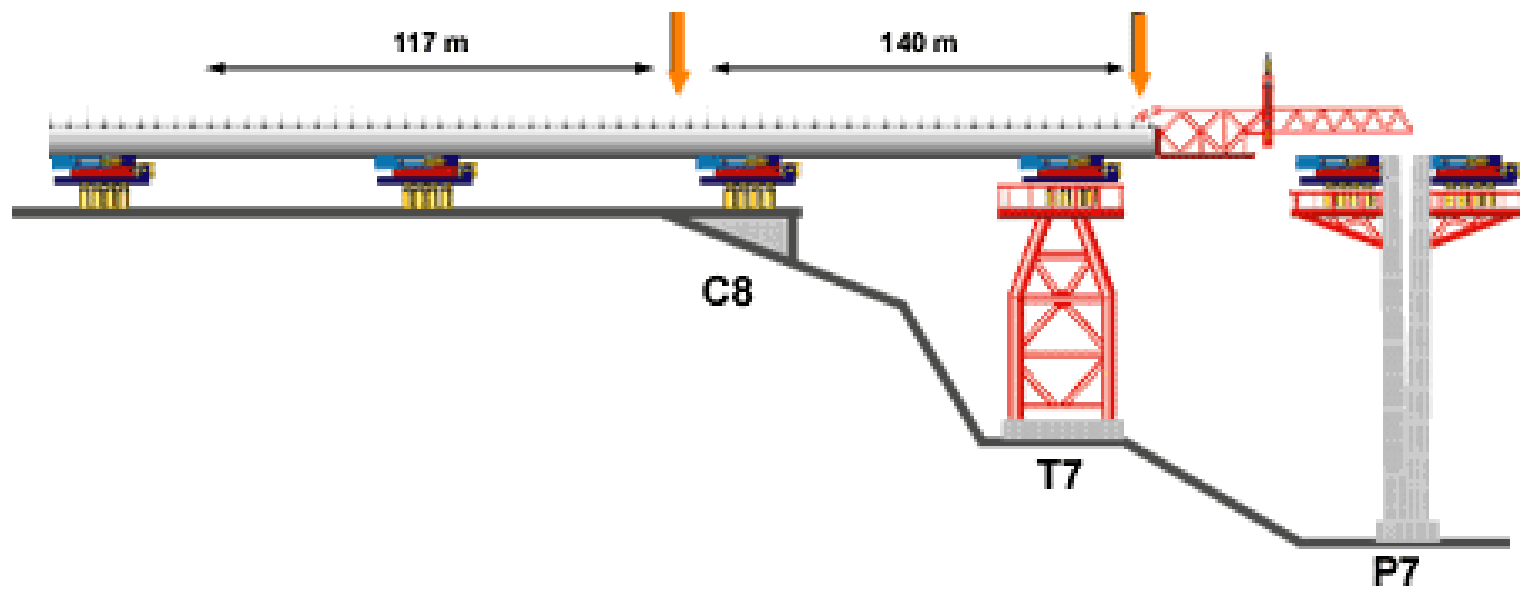

Figura 2.35 - Esquema da execução do tabuleiro (http://architetour.wordpress.com/2009/11/04/viaduto-de-millau/millau-3/) 


\subsubsection{TABULEIRO}

O tabuleiro é a parte da ponte por onde trafegam os veículos. O tabuleiro pode ser executado de diferentes maneiras, assim como ter diferentes geometrias, sempre buscando a forma que gere maior eficiência e menor custo.

Nas pontes estaiadas, o tabuleiro passou por muitos aprimoramentos, principalmente devido ao avanço nas modelagens matemáticas, que permitiram melhorar a geometria a ser utilizada. Com esse aperfeiçoamento, passou-se a conceber estruturas mais esbeltas, leves e, conseqüentemente, mais econômicas.

Nas primeiras pontes estaiadas, os espaçamentos dos pontos de fixação dos estais no tabuleiro eram, em geral, maiores do que os usados atualmente. Com isso, o tabuleiro precisava ser suficientemente rígido para resistir aos esforços de flexão longitudinal entre os pontos de fixação dos estais. Devido a este fator, predominaram na época os tabuleiros em estrutura metálica, pois se conseguia assim atingir a rigidez necessária sem a necessidade de ter um tabuleiro muito espesso e pesado, como acontecia com os tabuleiros de concreto.

Além do espaçamento, a maneira como o estai chega ao tabuleiro também gera influência sobre o mesmo. Quanto mais vertical for a chegada do estai, menores serão os esforços longitudinais atuando no tabuleiro e mais eficiente será o estai..

Os tabuleiros utilizados nas pontes estaiadas podem ser de diferentes materiais, cada um com suas vantagens e desvantagens, sendo eles:

- Tabuleiro de concreto

- Tabuleiro metálico

- Tabuleiro misto de concreto e aço

A seguir serão analisadas as particularidades de cada alternativa. 


\subsubsection{TABULEIRO DE CONCRETO}

Com a evolução da metodologia construtiva e dos materiais, as pontes estaiadas, que haviam sido executadas primeiramente com tabuleiros metálicos, passaram também a serem executadas com tabuleiros de concreto.

Para que essa mudança fosse possível dois métodos de execução se tornaram muito conhecidos: tabuleiros pré-fabricados e moldagens in loco através do método dos balanços sucessivos.

No método dos balanços sucessivos utilizando peças pré-fabricadas, as mesmas são içadas ao local fazendo-se as devidas ligações com as peças já instaladas na ponte. Este método acelera de maneira significativa a construção, uma vez que são evitados os problemas de montagem de armadura no próprio tabuleiro, concretagem da peça e aguardar o tempo mínimo de cura do concreto.

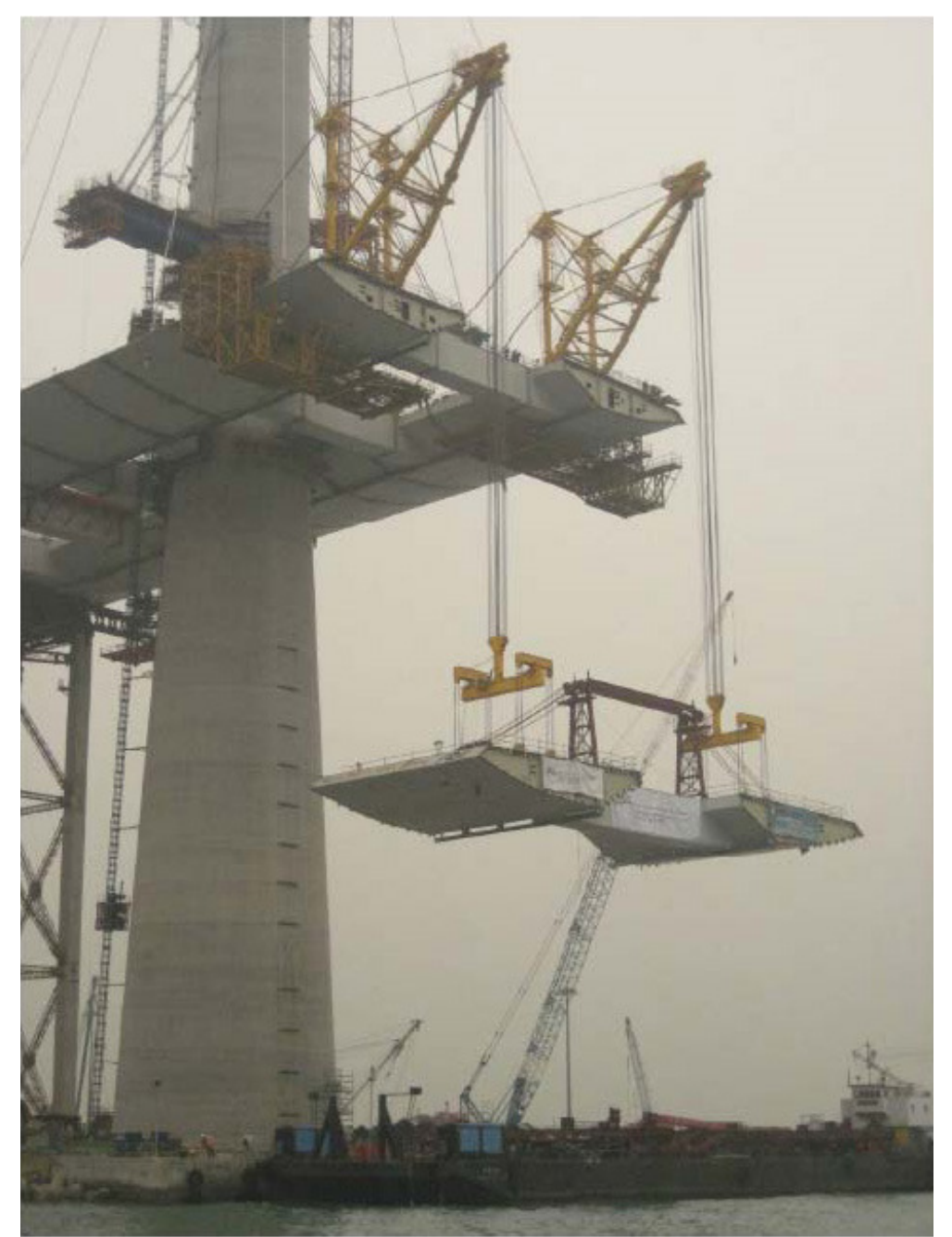

Figura 2.36 - Içamento de tabuleiro pré-moldado (http://www.transportscotland.gov.uk) 
A ligação das aduelas, no caso de tabuleiros de concreto, se dá através de encaixes entre as peças, assim como pela aplicação de uma cola especifica nas faces de contato e realizando uma protensão horizontal entre as peças, de maneira a mantê-las unidas.

Já no método dos balanços sucessivos moldados in loco, cada novo trecho é executado no próprio local da obra, exigindo um canteiro de obras mais completo sobre o tabuleiro já construído. Este método é muito útil quando as condições geométricas e logísticas da execução da ponte não permitem que peças sejam içadas até o local da obra, seja devido à elevada altura da ponte ou pela existência de outra via passando por baixo da ponte.

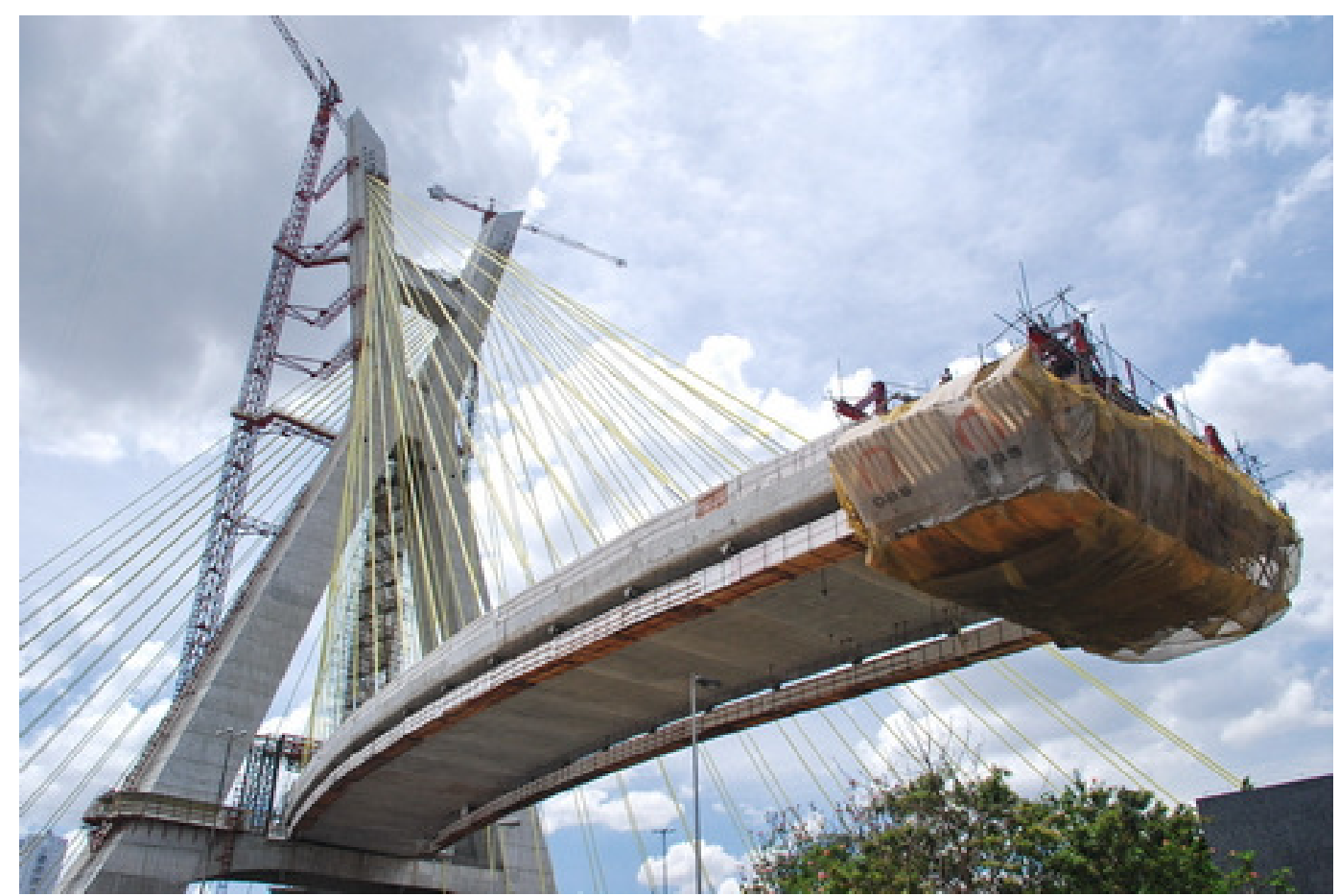

Figura 2.37 - Método das aduelas sucessivas - Ponte Octavio Frias de Oliveira (http://tempestivo.files.wordpress.com/2008/11/ponte20de40be1.jpg)

As primeiras pontes estaiadas com seção de concreto se apresentaram como estruturas pesadas, de geometria robusta e com custo de execução elevado. Mas, com o tempo, a experiência e a tecnologia se desenvolveram de maneira a possibilitar um dimensionamento visando a uma estrutura de geometria otimizada, que seja resistente, aerodinâmica e leve ao mesmo tempo. 
Pode-se notar a diferença significativa nas dimensões do tabuleiro, e também das torres, analisando as estrutura das pontes a seguir, que mostram claramente a evolução da técnica de se executar ponte estaiadas com tabuleiro de concreto.

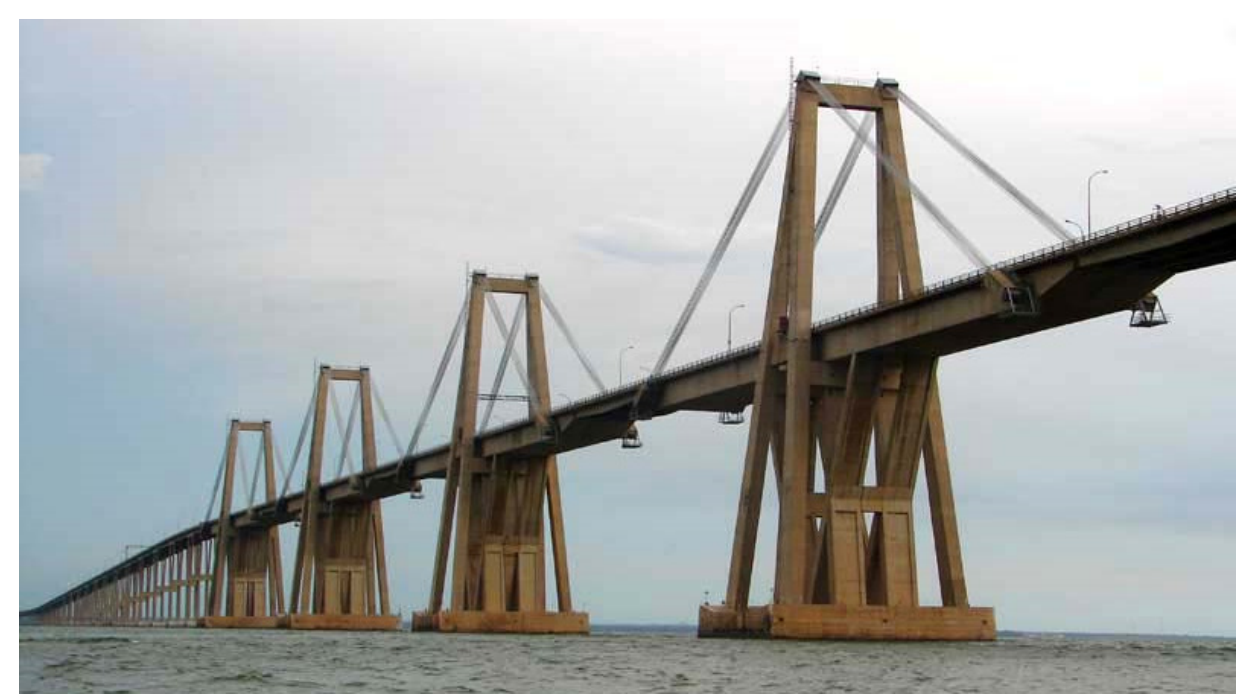

Figura 2.38 - Ponte Maracaibo - Venezuela

(http://www.randytrahan.com/ocov/images/Gen_Interest/Gen_Interest_Gallery03/034.jpg)

Nota-se na Ponte Maracaibo, uma das primeiras pontes estaiadas feitas inteiramente de concreto, que o tabuleiro e as torres são peças de grandes dimensões. Isso se deve à maneira como a estrutura foi concebida. Visualmente já se percebe a quantidade de material que foi necessária para executar esta obra e o custo elevado para sua execução.

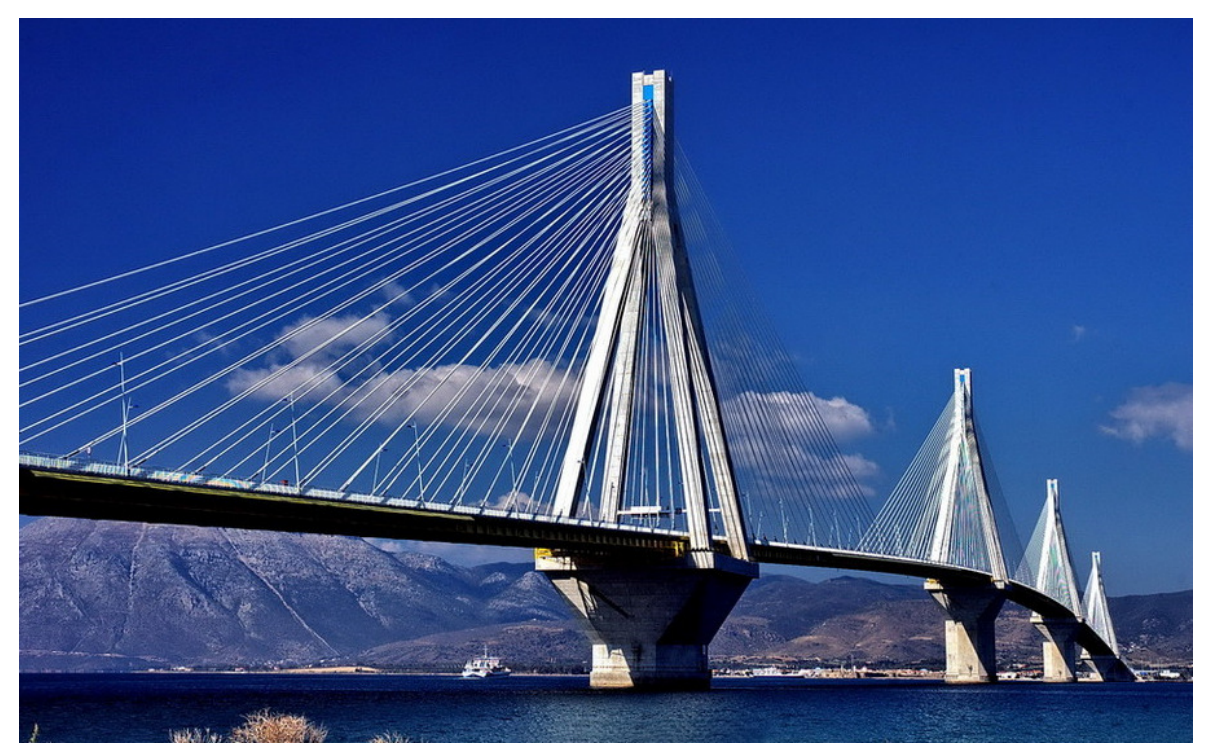

Figura 2.39 - Ponte Rion Antirion - Grécia (http://www.fotocommunity.com/pc/pc/display/17876159) 
Na Ponte Rion Antirion, localizada na Grécia e construída em 2004, nota-se uma completa diferença em relação à ponte Maracaibo. Nesta ponte, a elevada quantidade de estais, assim como seu pequeno espaçamento longitudinal, permite que o esforço predominante atuando no tabuleiro seja o momento transversal, de maneira que se obtenha um tabuleiro mais leve, esbelto e econômico, diferente da ponte Maracaibo, na qual o esforço predominante é o momento longitudinal.

Outro fator que permitiu que as seções se tornassem mais esbeltas foi 0 concreto protendido, que possibilitou a adoção de estruturas vazadas. Estas seções são muito vantajosas, uma vez que reduzem o consumo de material, e aliviam o peso da estrutura, conforme mostrado na figura 2.40.

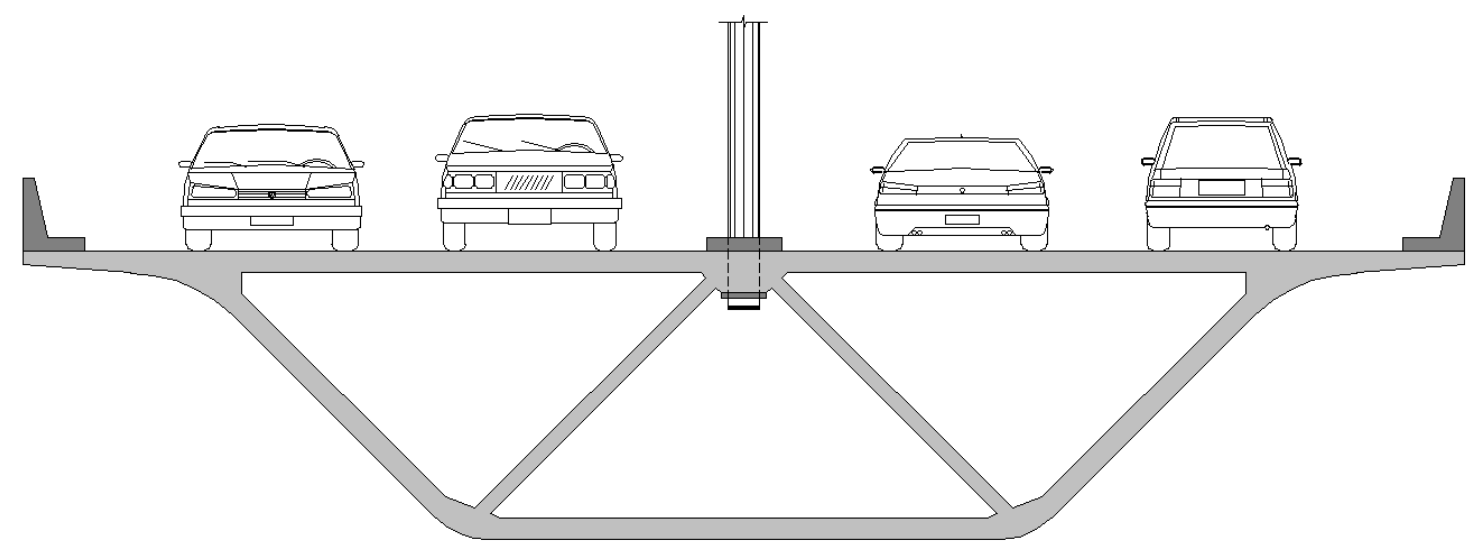

Figura 2.40 - Seção vazada de concreto protendido

O concreto protendido trouxe inúmeras vantagens às pontes estaiadas, pois permitiu que se aproveitasse ao máximo a melhor qualidade do concreto, que é a resistência a compressão, fazendo com que haja uma considerável redução nos efeitos de flexão do tabuleiro

Um dos exemplos deste tipo de solução é a ponte Brotonne, localizada na França. Sua seção transversal, indicada na figura 2.41, é composta por peças préfabricadas protendidas. Esta geometria foi concebida de maneira que os esforços que atuam no tabuleiro sejam transferidos para o ponto central de suspensão pelos estais. 


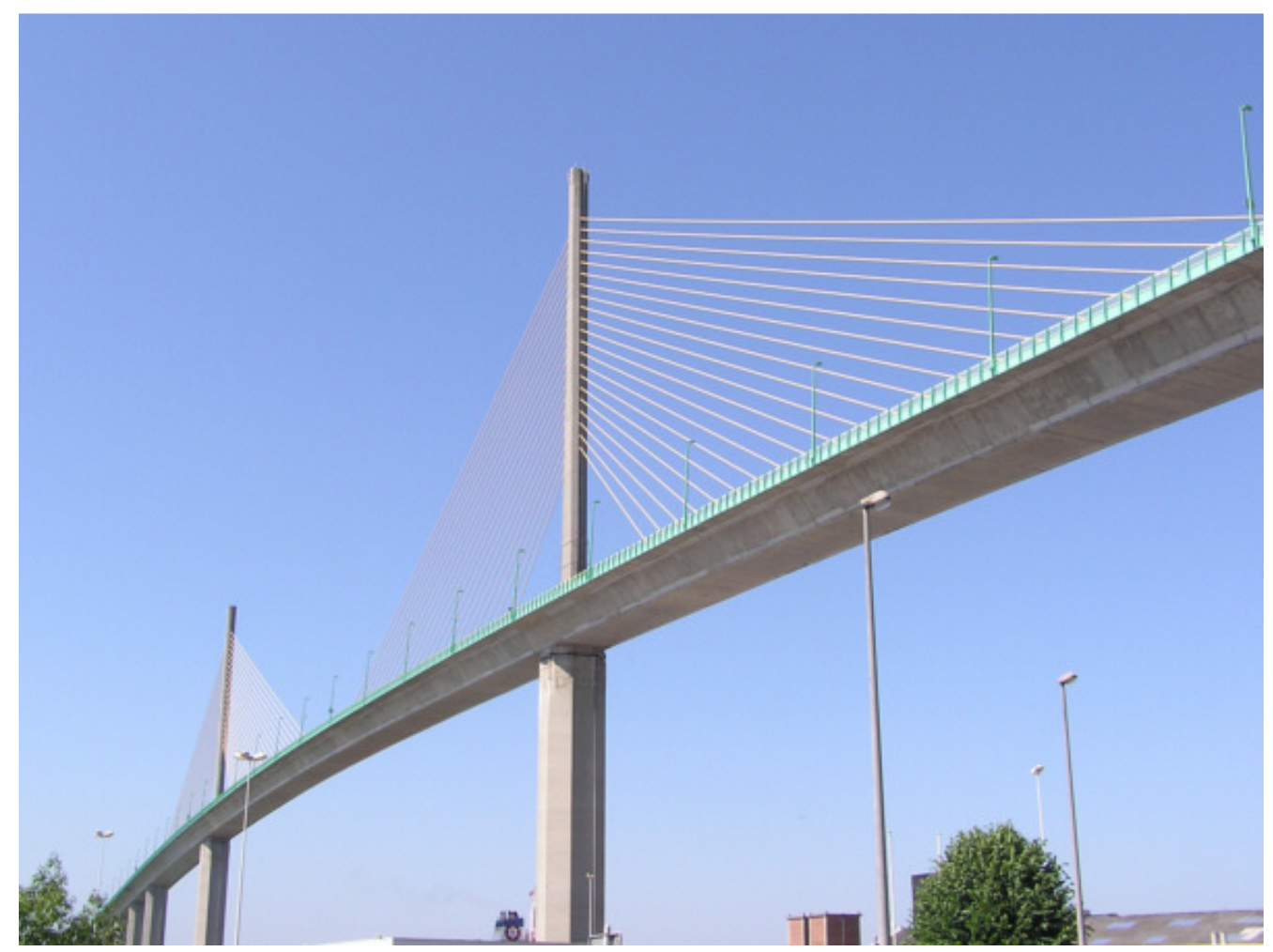

Figura 2.41 - Ponte Brotonne - França (http://en.structurae.de/photos/index.cfm?JS=67653)

A ponte Barrios de Luna, localizada na Espanha, é outro exemplo típico de como a solução de seções de concreto protendido pode ser viável e econômica. Esta ponte possui um vão central de $440 \mathrm{~m}$, sendo o maior vão da época em que foi construída, e seção transversal vazada conforme a figura 2.42 .

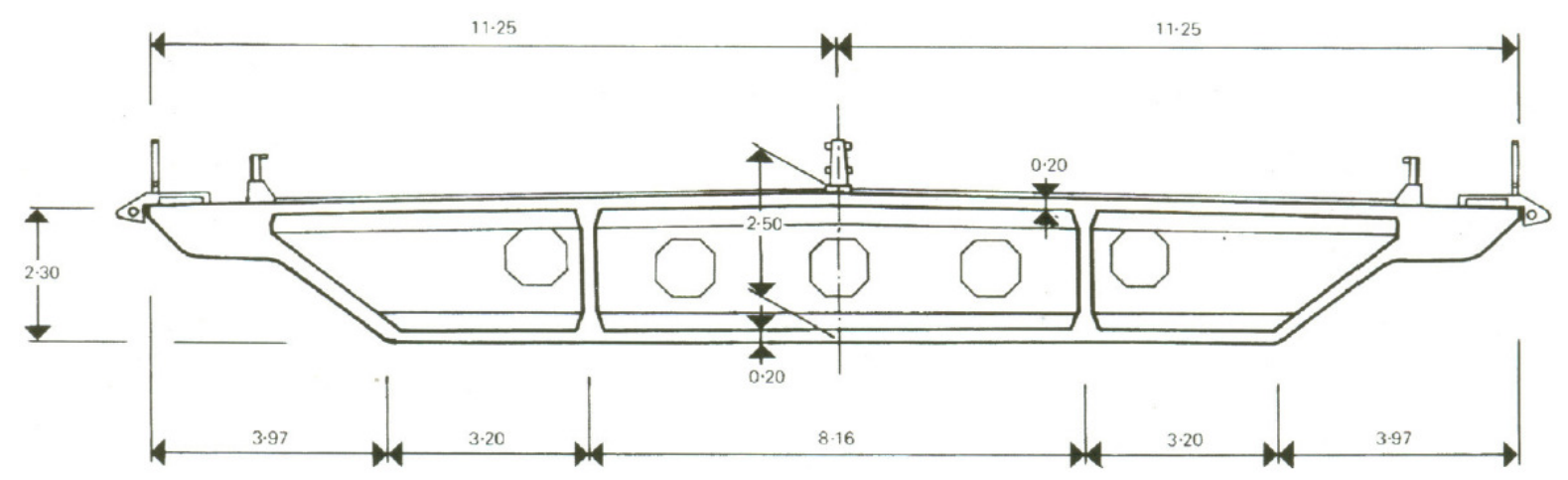

Figura 2.42 - Seção da ponte Barrios de Luna (WALTHER, R.)

Nota-se que esta seção de $22,5 \mathrm{~m}$ de largura e 2,30 $\mathrm{m}$ de espessura é esbelta para o seu comprimento de $440 \mathrm{~m}$. 


\subsubsection{TABULEIRO METÁLICO}

Os tabuleiros com seção de aço foram muito utilizados nas primeiras pontes estaiadas, tanto pela relativa facilidade de execução quanto por ser um material bem conhecido e estudado na época graças às inúmeras pontes metálicas em arco construídas neste período.

Em geral, os tabuleiros de aço são até $80 \%$ mais leves que os tabuleiros em concreto, porém estes se apresentam mais caros de serem executados que os tabuleiros de concreto. Com essa diferença de peso, os tabuleiros metálicos geram uma redução do peso total da estrutura e, consequentemente, uma redução nas dimensões dos estais, pilares e fundações. Este fato faz com que as pontes com seções metálicas se tornem tão atraentes quanto as pontes com seções de concreto, e sua escolha dependerá das preferências do projetista e do partido arquitetônico desejado e, acima de tudo, do custo esperado para a obra. No Brasil o custo para a execução de pontes estaiadas com tabuleiro metálico é muito elevado devido ao preço cobrado pelo material e pelas empresas que executam este tipo de estrutura.

A utilização de tabuleiros de aço normalmente é mais interessante em estruturas de grandes vãos, pois em estruturas menores o alivio de peso não é tão perceptível.

Outro fator importante para a decisão de qual material a ser utilizado é a fadiga do material. Tanto em estruturas de concreto quanto em estruturas metálicas este fator deve ser considerado, mas cada material possui suas particularidades.

Além disso, a verificação da ação do vento também é importante, devido à redução do peso da estrutura, o que a torna mais suscetível a oscilações, uma vez que a massa a ser deslocada é menor.

Como exemplo deste tipo de solução, pode-se mencionar a Ponte Stonecutters, em Hong Kong. Dimensionada para resistir à ação de ventos de elevada velocidade de projeto, aproximadamente $95 \mathrm{~m} / \mathrm{s}$, a ponte de $1018 \mathrm{~m}$ de vão livre, que é atualmente o segundo maior vão livre do mundo, possui tabuleiro duplo em estrutura metálica, composto por caixões de aço com placas ortotrópicas. 


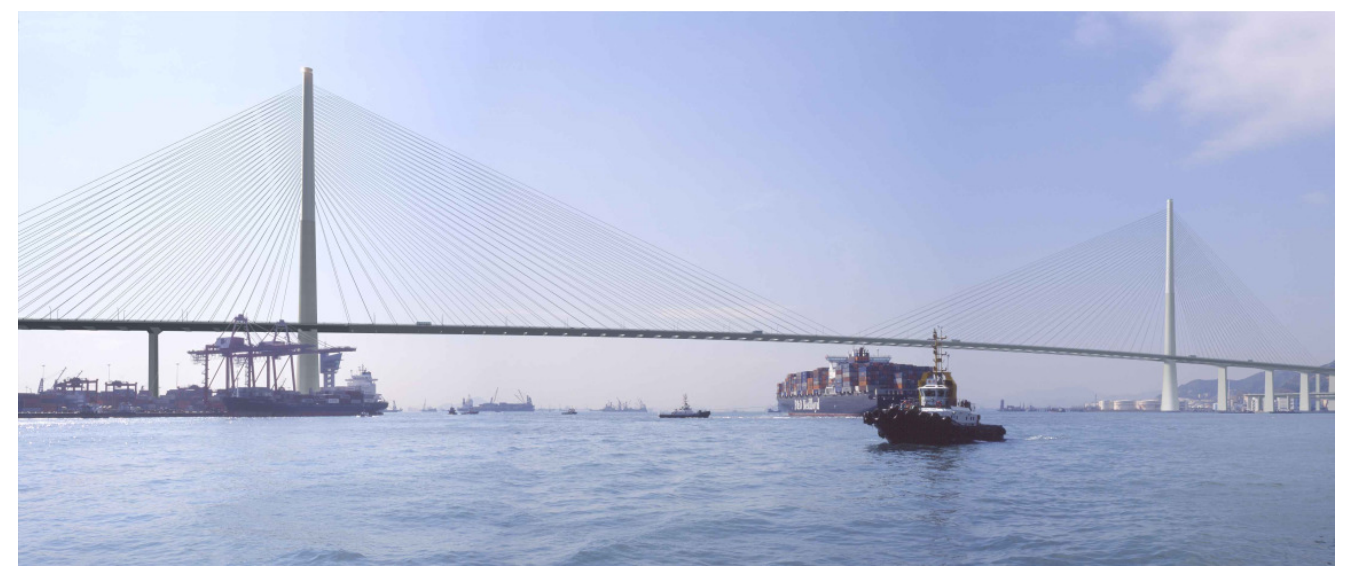

Figura 2.43 - Ponte Stonecutters (http://www.flintneill.com/archive-noticeboard/)

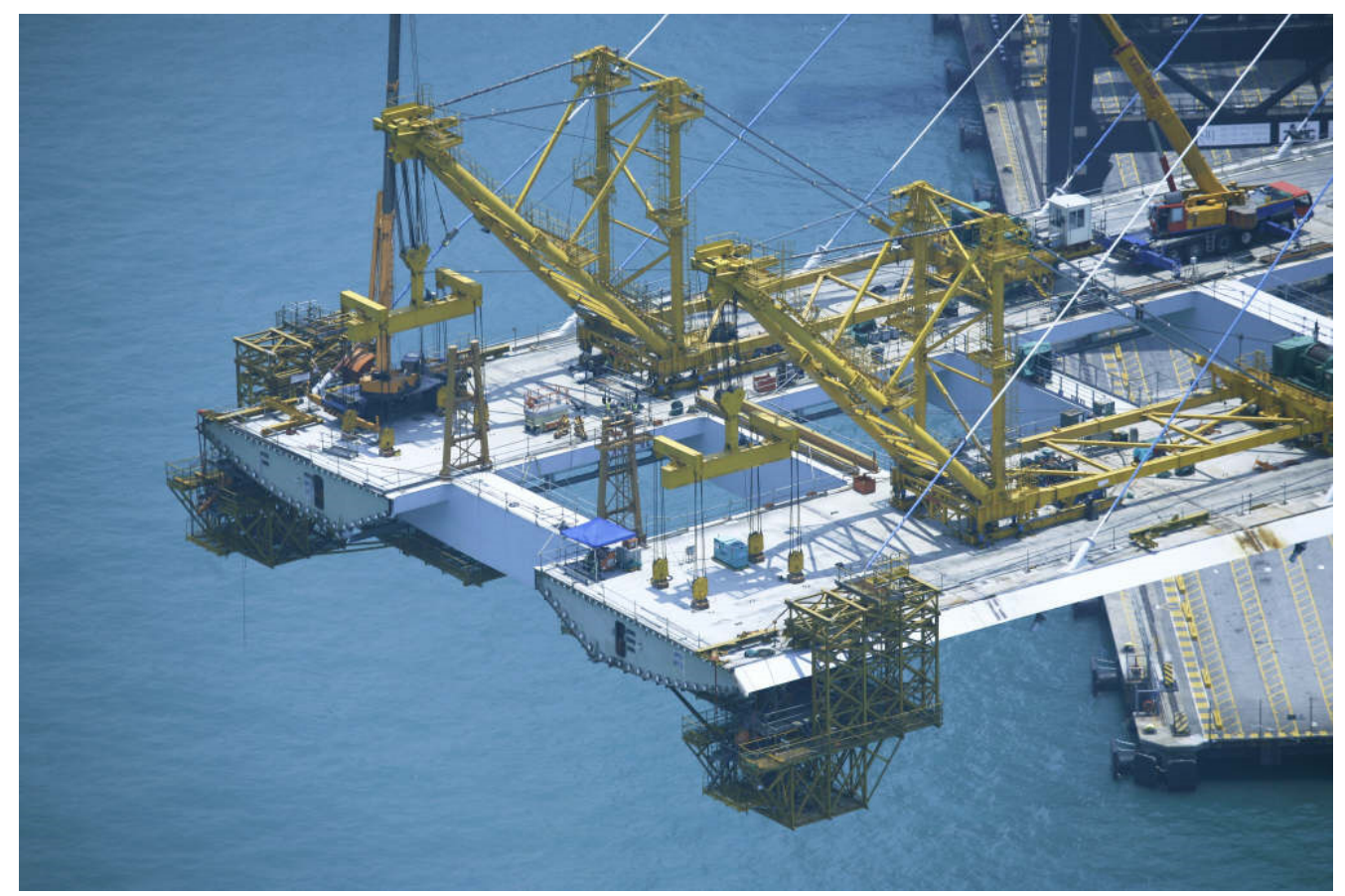

Figura 2.44 - Construção da Ponte Stonecutters (http://www.arup.ie/index.jsp?p=125\&n=144)

\subsubsection{TABULEIRO MISTO DE CONCRETO E AÇO}

Nos tabuleiros mistos, com a utilização do aço e do concreto, podem-se obter inúmeras vantagens, sendo algumas delas:

- Redução no peso da seção devido à utilização de perfis metálicos;

- Facilidade no transporte e instalação dos perfis metálicos; 
- Durabilidade da laje de concreto;

- Rapidez na execução.

Um exemplo deste tipo de solução é a Ponte da Passagem, localizada em Vitória, no Espírito Santo. Esta ponte foi projetada pelo engenheiro Karl Meyer, e é composta por mastros metálicos e tabuleiro misto de concreto e aço.

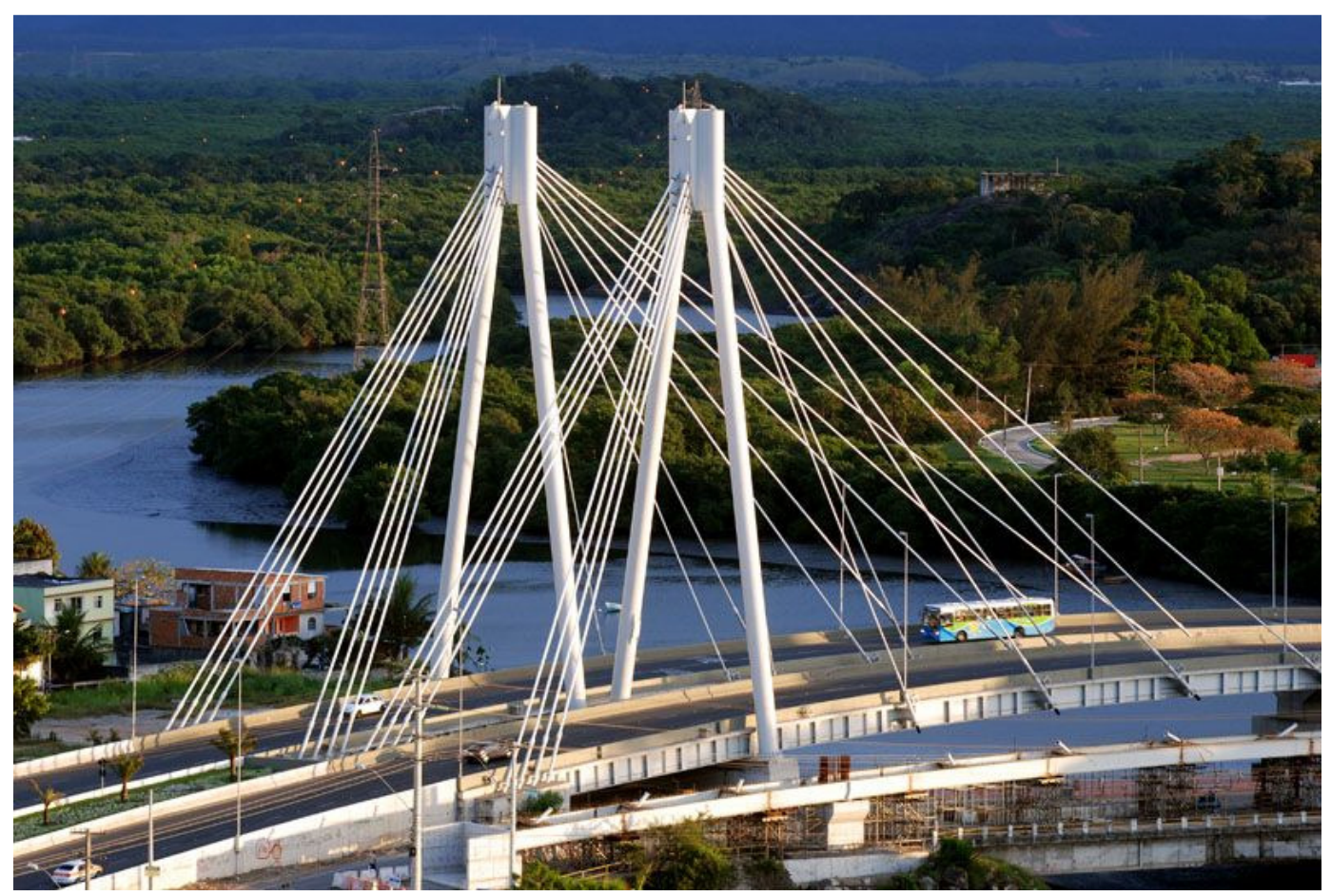

Figura 2.45 - Ponte da Passagem

(Portal do Governo do Estado do Espírito Santo - http:// www.vitoria.es.gov.br) 


\subsubsection{MÉTODOS CONSTRUTIVOS}

Para a execução do tabuleiro, existem alguns métodos construtivos que foram largamente utilizados durante a construção das pontes estaiadas, sendo os principais:

\section{- Escorado:}

Esta metodologia mostra-se uma das mais limitadas, uma vez que o custo com escoramento e cimbramentos é muito alto, principalmente em locais onde o tabuleiro se encontra muito distante do solo. Onde há a travessia de rios ou mar o cimbramento mostra-se praticamente inviável pelo seu custo e dificuldade de execução.

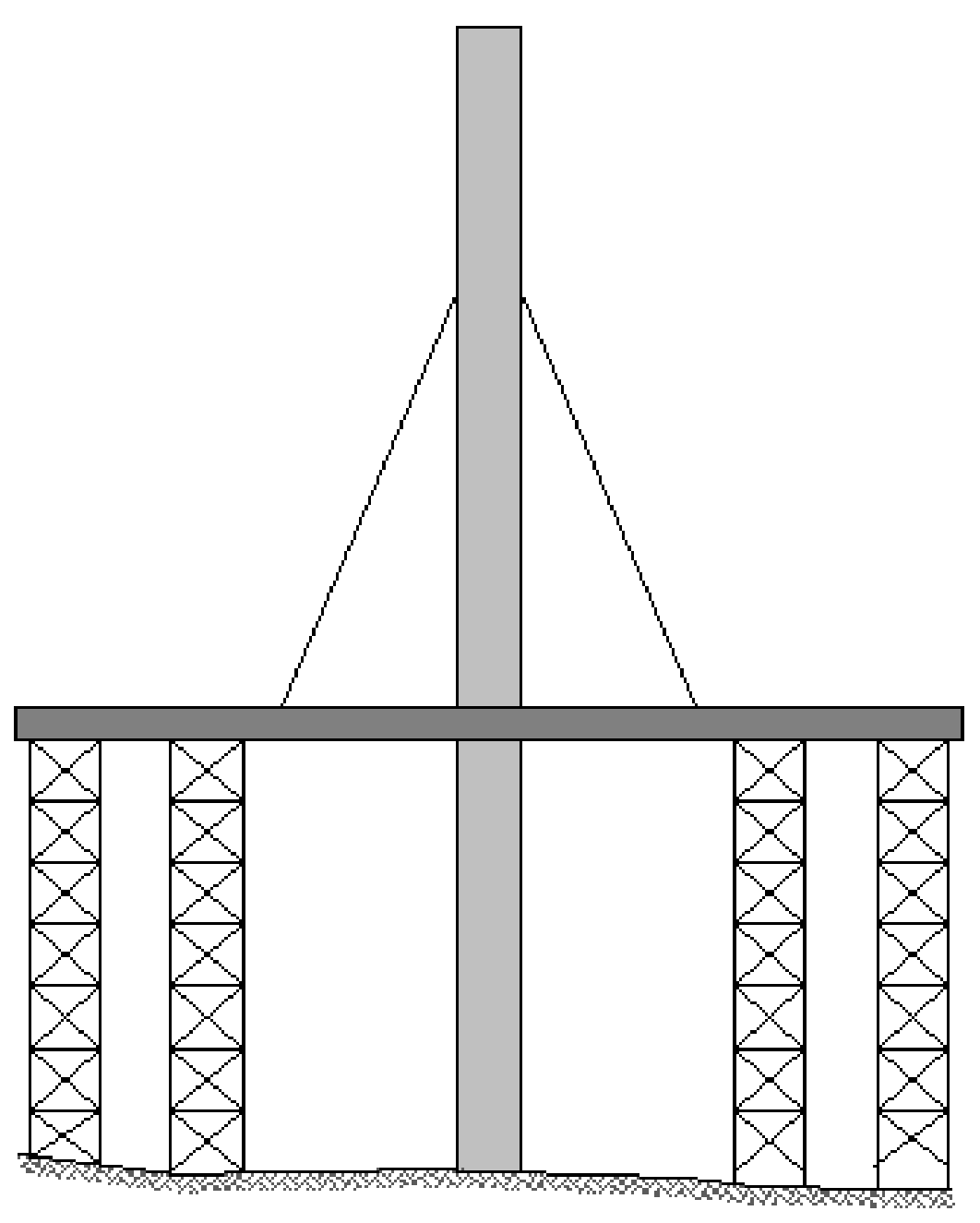

Figura 2.46 - Vista lateral de tabuleiro executado com escoramentos 
- Balanços sucessivos moldados in-loco

Nos balanços sucessivos, ou aduelas sucessivas, utiliza-se o trecho já executado para servir de sustentação para o próximo trecho, evitando-se a utilização de escoramentos, reduzindo com isso as interferências no local onde a ponte será executada.

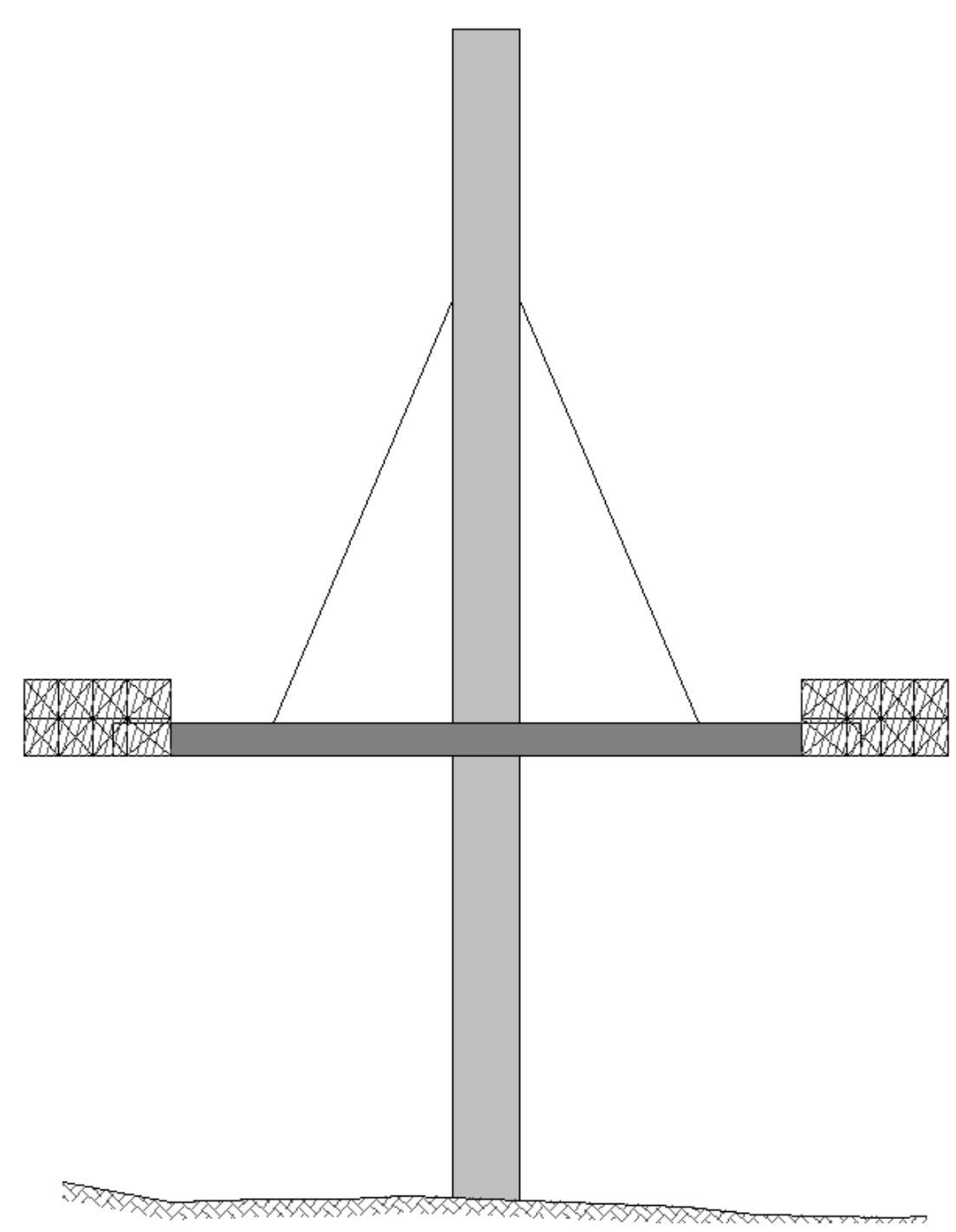

Figura 2.47 - Vista lateral de tabuleiro executado através do método dos balanços sucessivos 
- Balanços sucessivos com elementos pré-moldados

No método das aduelas sucessivas com elementos pré-moldados há um ganho de velocidade pelo fato de as peças serem executadas fora da ponte, em um canteiro próprio, em condições mais favoráveis.

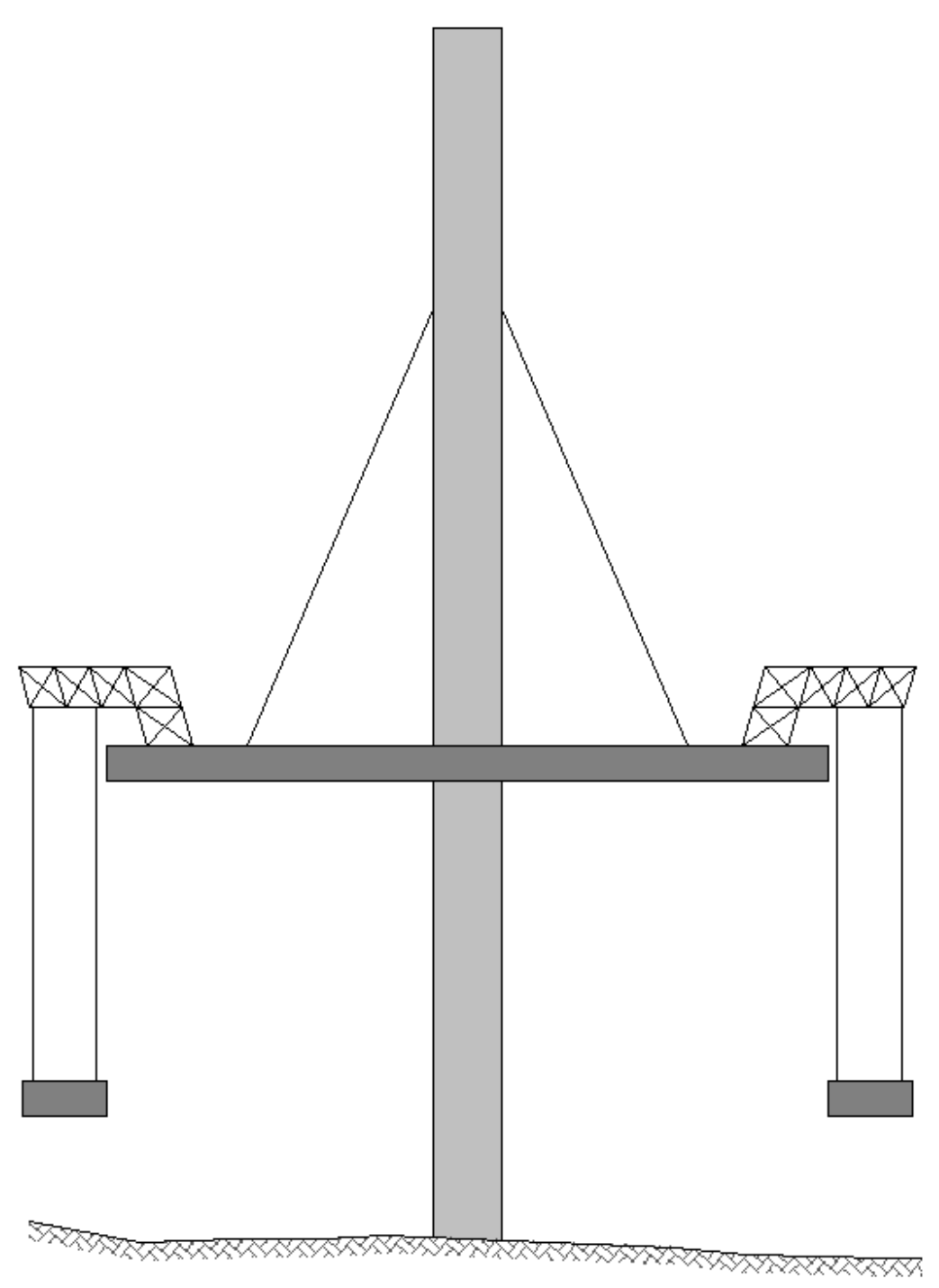

Figura 2.48 - Vista lateral de tabuleiro executado através do método dos balanços sucessivos com elementos pré-moldados

As aduelas pré-moldadas podem ser em concreto ou metálicas, alterando-se apenas a metodologia de encaixe e fixação das peças içadas até o local com as peças já solidarizadas. 


\section{APLICAÇÃO DAS PONTES ESTAIADAS NO BRASIL}

\subsection{ASPECTOS GERAIS}

O surgimento das pontes estaiadas no Brasil é mais recente do que em outros países, sendo que isso se deve ao fato de que a técnica empregada neste tipo de construção não era difundida na engenharia nacional.

Com a consultoria de empresas estrangeiras, e com o aperfeiçoamento dos profissionais brasileiros, foi possível a utilização deste tipo de solução estrutural nas pontes nacionais. Atualmente existem algumas empresas que são reconhecidas nacional, e internacionalmente, que projetam este tipo de estrutura no país.

Atualmente vem se utilizando muito a solução de pontes estaiadas no Brasil como um todo, mesmo em situações onde não seria necessária a utilização deste tipo de ponte. Isso se deve principalmente ao fato de que as empresas nacionais possuem o domínio da técnica utilizada nestas pontes, e pelo fator estético que foi bem aceito pela população, que considera estas estruturas como ponto de referência e cartão postal para as cidades.

\subsection{PONTE ESTAÇÃO ENG. JAMIL SABINO}

A primeira ponte estaiada brasileira começou a ser construída apenas no ano de 2000, em São Paulo, sendo esta a Ponte-Estação Santo Amaro (Estação Eng. Jamil Sabino). Esta ponte faz parte do empreendimento da ligação metroviária Capão Redondo - Largo Treze, da linha 5 do Metrô de São Paulo. 


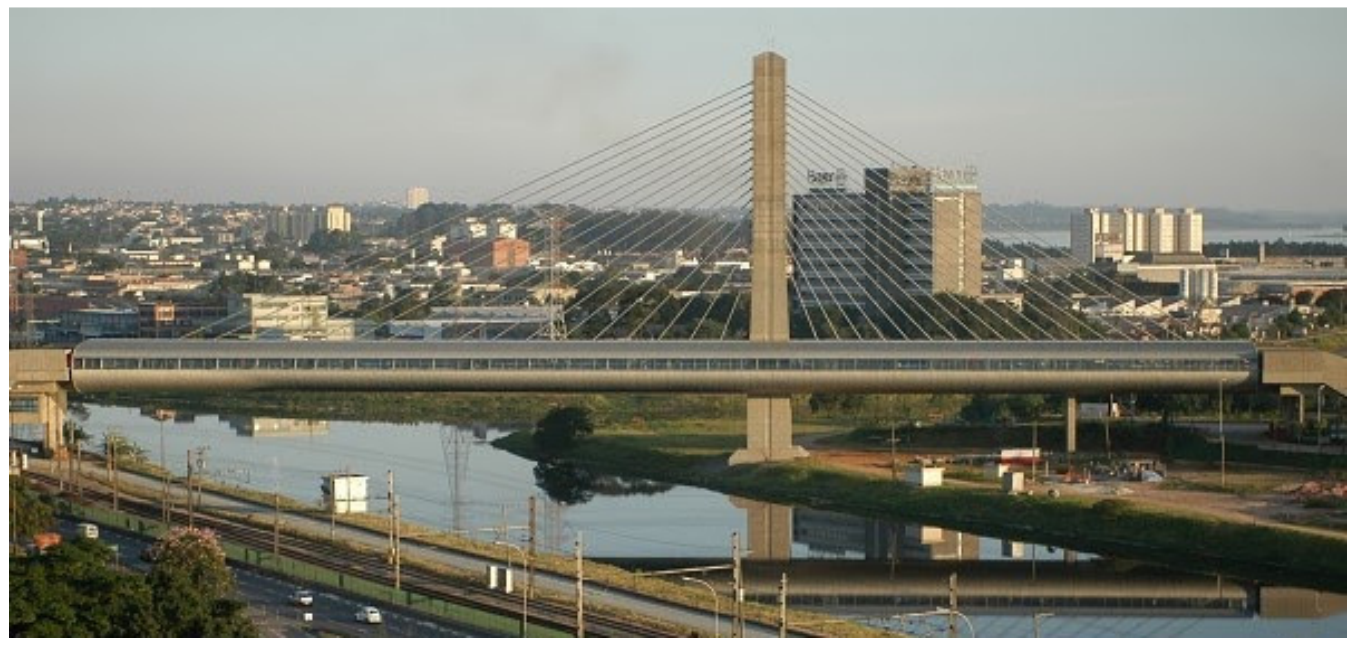

Figura 3.1 - Ponte e Estação Estaiada Santo Amaro (http://www.encontrasantoamaro.com.br/santoamaro/estacao-santo-amaro.shtml)

A denominação de "ponte estação" se deve ao fato de a estação da linha 5 do metro ser a própria ponte, que foi construída sobre o Rio Pinheiros.

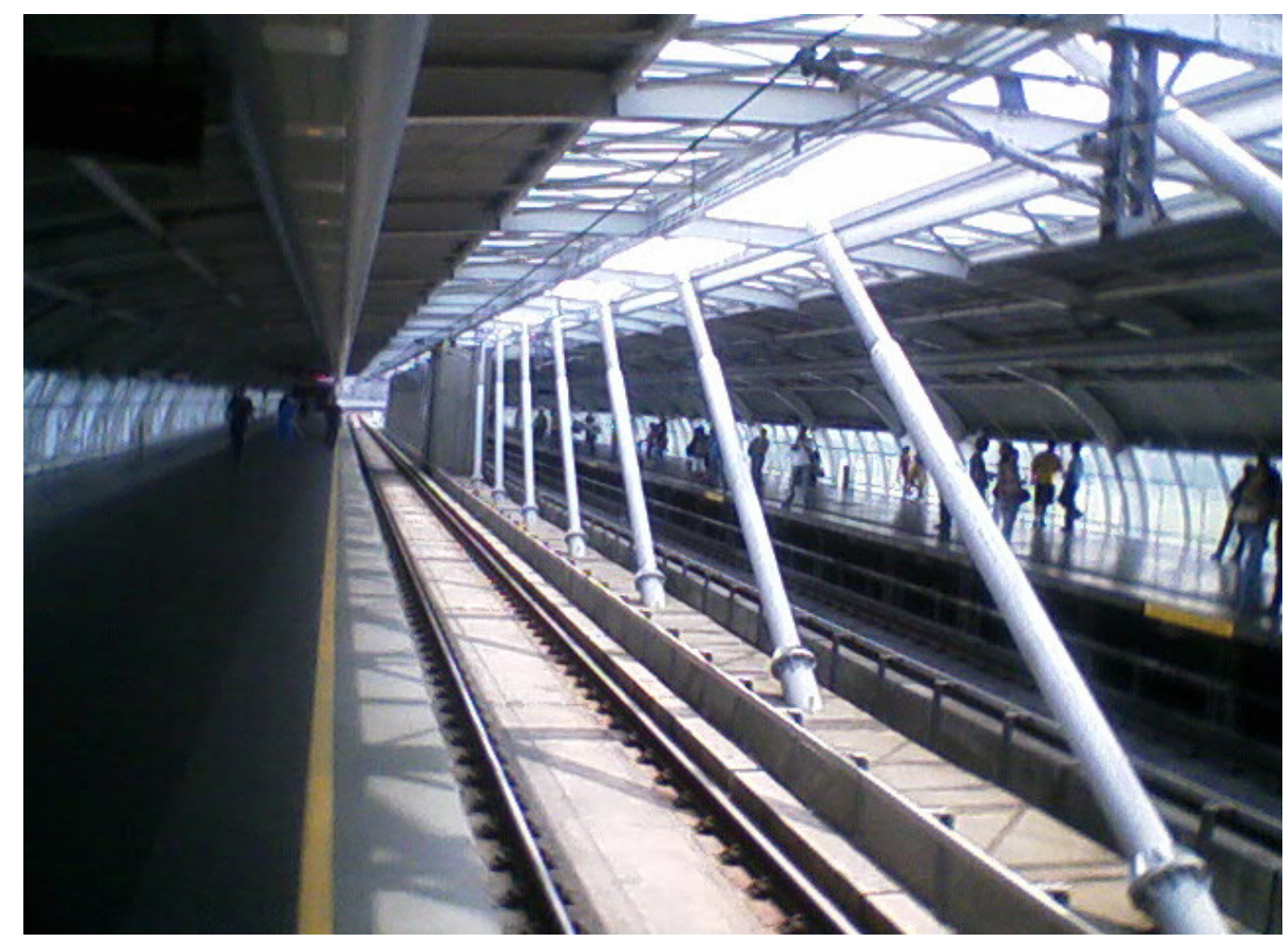

Figura 3.2 - Vista interna da Ponte e Estação Estaiada Santo Amaro (http://www.skyscrapercity.com/showthread.php?t=605941\&page=2)

Localizada na Avenida das Nações Unidas, no bairro de Santo Amaro, em São Paulo, a ponte estação liga as duas margens do Rio Pinheiros. (figura 3.3). 


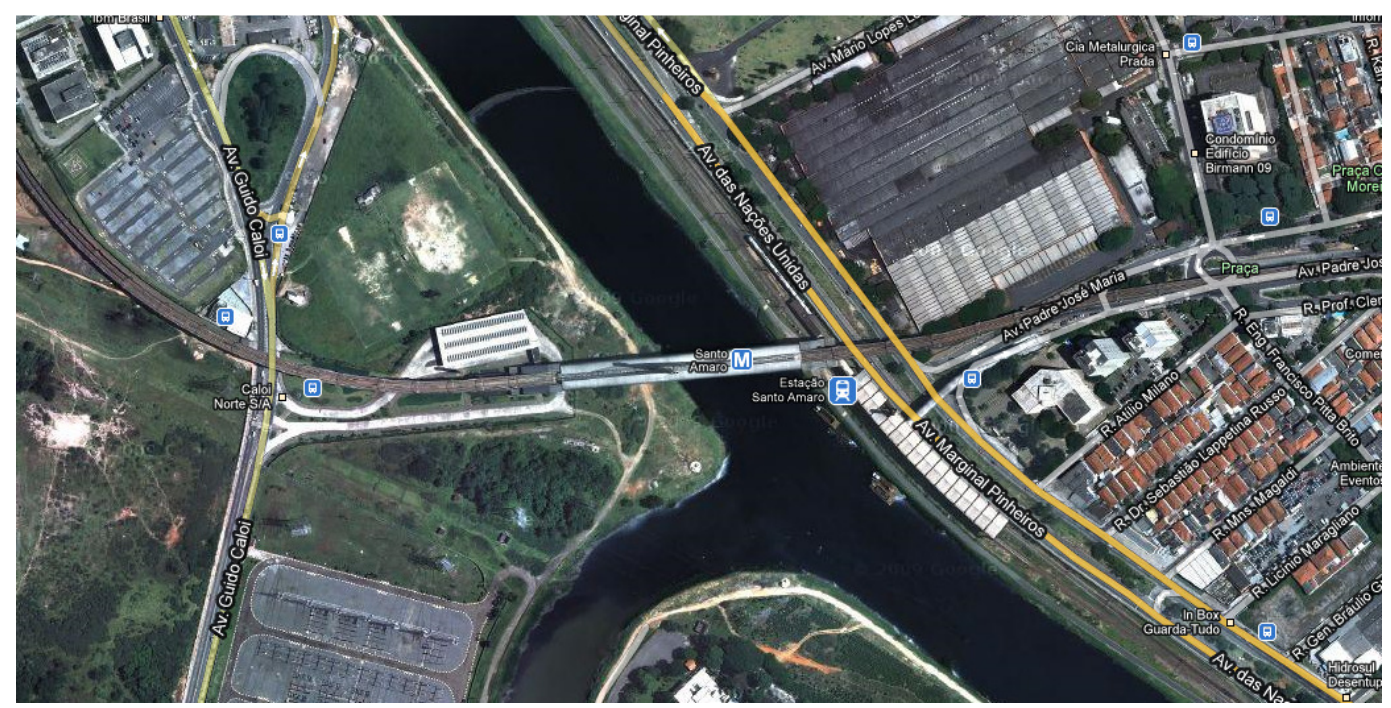

Figura 3.3 - Vista de Satélite da Ponte e Estação Santo Amaro (Google Maps)

A Ponte Estação Santo Amaro foi projetada pela ENESCIL Engenharia de Projetos, sob a responsabilidade do Eng. Catão Francisco Ribeiro, e executada pela Construtora OAS Ltda. A concepção arquitetônica da ponte ficou a critério do arquiteto Luiz Estevez.

A ponte estação Santo Amaro possui uma área total 9.018,69 $\mathrm{m}^{2}$, sendo $4.360,63 \mathrm{~m}^{2}$ de vias e plataformas de embarque e desembarque, e os demais 4.638,06 $\mathrm{m}^{2}$ de estação de transbordo de passageiros, salas operacionais, salas técnicas e porões de cabos do metrô. Além disso, há uma integração Metrô - Ônibus de um lado do Rio Pinheiros, e do lado oposto há a integração Metrô - Trem (linha C da CPTM).

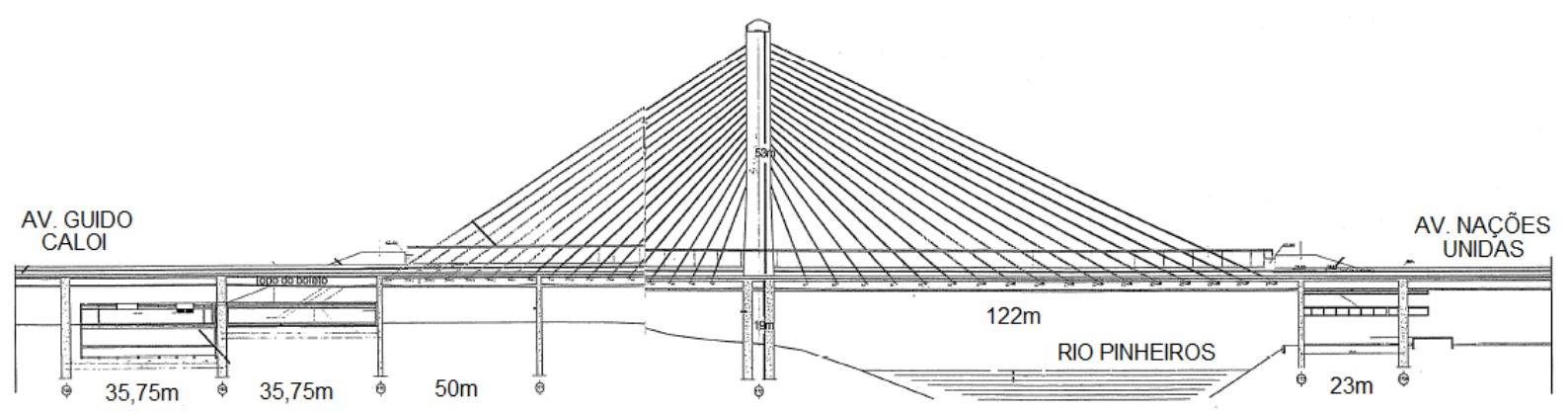

Figura 3.4 - Vista lateral da Ponte e Estação Estaiada Santo Amaro (Revista Ferroviária, 2000 apud SANTOS, 2008) 
Esta ponte possui um único plano vertical central de estaiamento, que fica situado entre as duas linhas férreas. Os cabos estão dispostos na geometria de semi-harpa. A extensão total da ponte é de $230,75 \mathrm{~m}$, sendo estes divididos da seguinte maneira: dois vãos não estaiados de $35,75 \mathrm{~m}$, um vão estaiado de $35,75 \mathrm{~m}$ e um com 50 m, um vão livre estaiado de 122 m sobre o Rio Pinheiros, e um vão não estaiado de $23 \mathrm{~m}$.

Sua fundação foi executada em tubulões a ar comprimido, com camisa de aço perdida. Para o mastro foram utilizados nove tubulões de $1,80 \mathrm{~m}$ de diâmetro e apoiados sobre rocha.

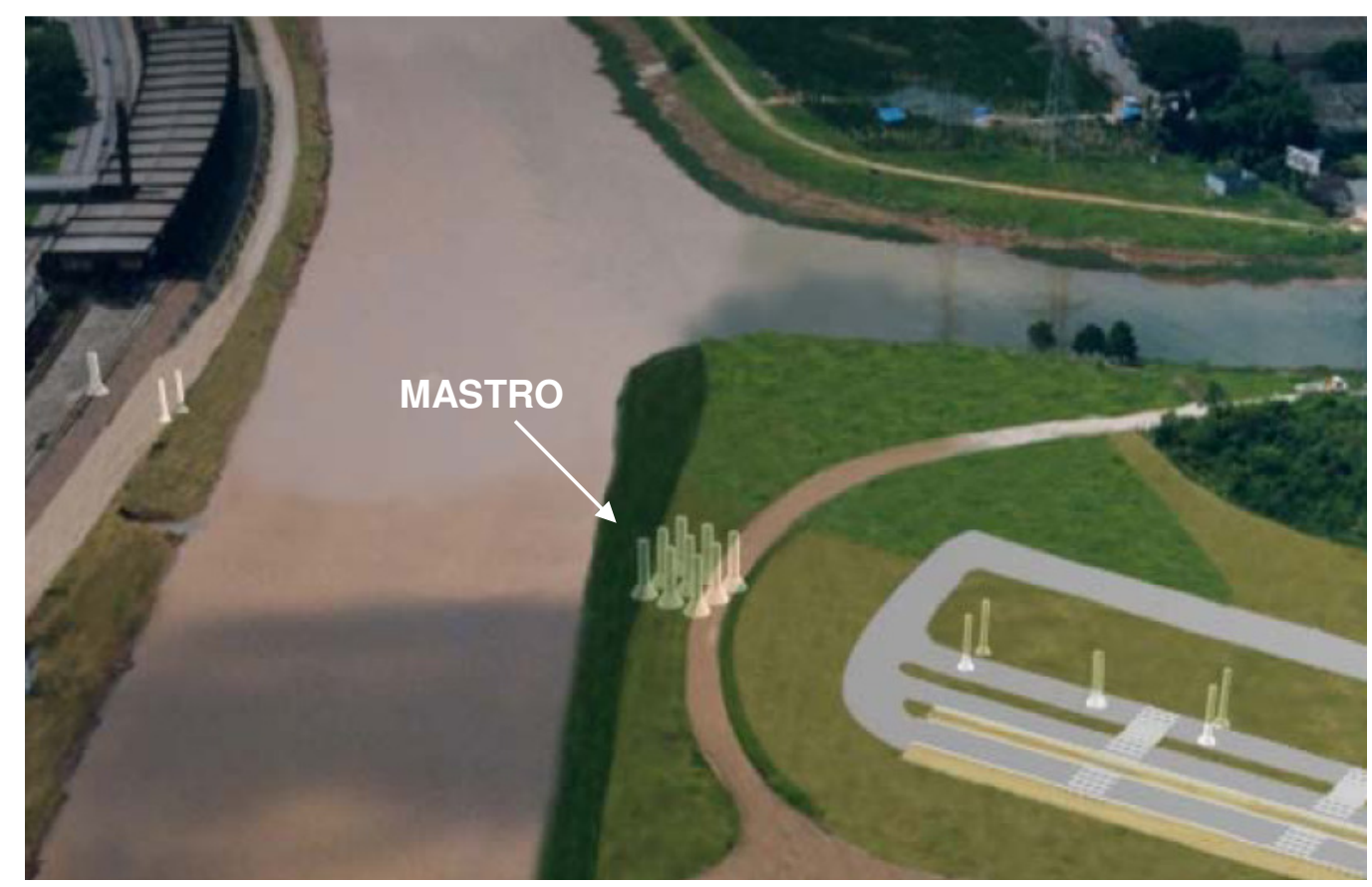

Figura 3.5 - Disposição dos tubulões (OAS, 2000 apud SANTOS, 2008)

O tabuleiro da ponte é constituído por um caixão unicelular em concreto protendido, de 8,3 $\mathrm{m}$ de largura e espessura de 2,5 $\mathrm{m}$ no centro.

O mastro da ponte possui $53 \mathrm{~m}$ de altura acima do tabuleiro, e $67,5 \mathrm{~m}$ de altura total. Ele foi executado com duas seções distintas, sendo o trecho sob 0 tabuleiro com seção variável de concreto armado, e acima do tabuleiro em concreto protendido, com seção constante na região de ancoragem dos estais. A seção do mastro é vazada, de maneira que se possa fazer a manutenção das ancoragens dos estais, e sua eventual substituição. 


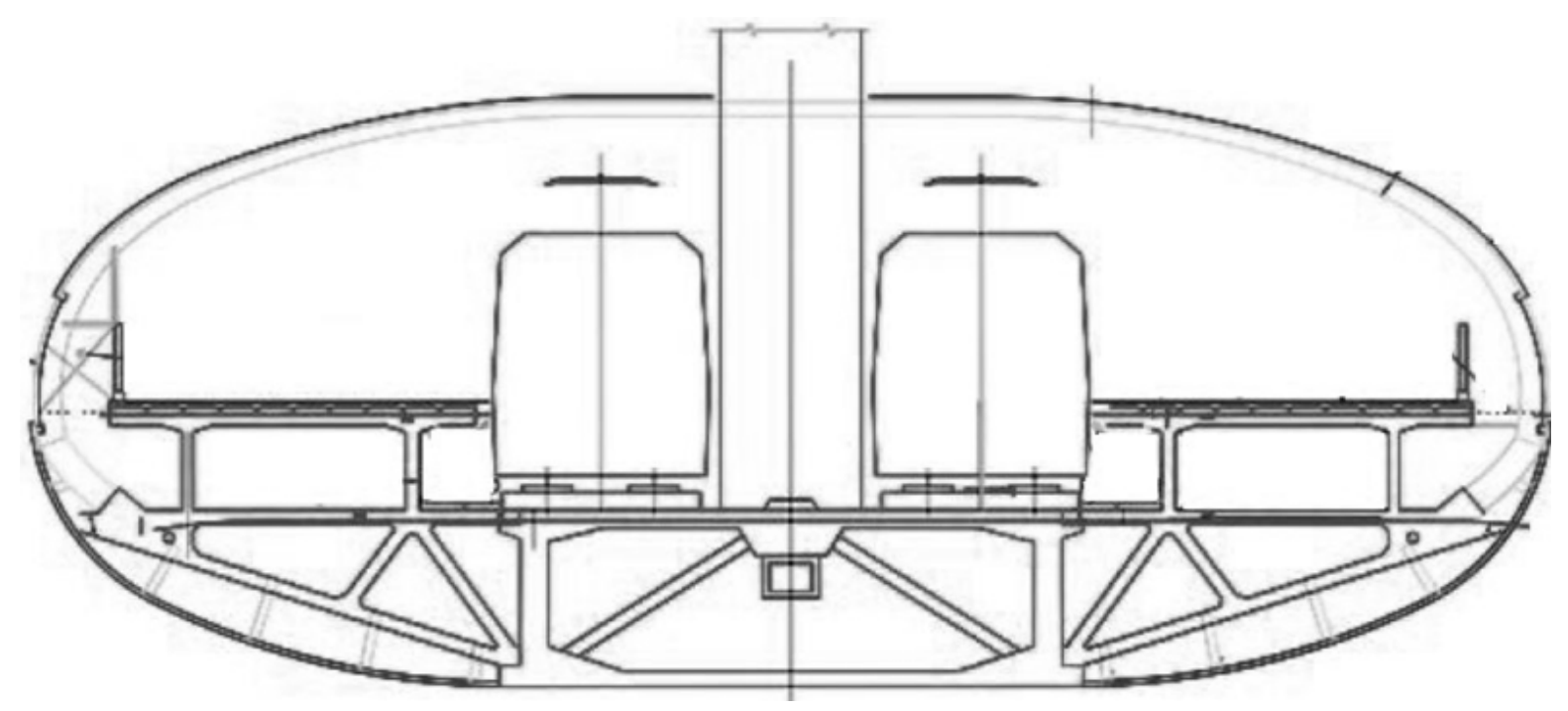

Figura 3.6 - Corte transversal da ponte (OAS, 2000 apud SANTOS, 2008)

A execução do mastro foi feita com formas deslizantes, garantindo se a assim a geometria constante até o topo.

Os estais em forma de semi-harpa foram dispostos em um único plano central de estaiamento, sendo que os opostos são discretamente assimétricos.

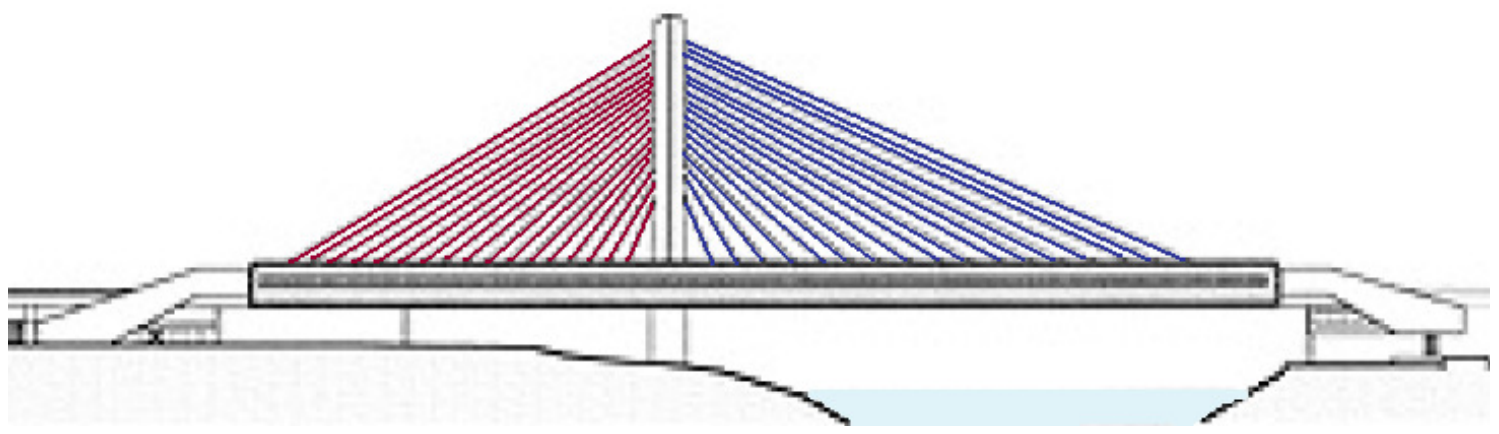

Figura 3.7 - Espaçamentos distintos dos estais (OAS, 2000 apud SANTOS, 2008)

A sustentação é feita por 34 estais, sendo que 17 são igualmente espaçados ao longo dos vãos de equilíbrio, que não estão sobre o rio Pinheiros. Os demais estão igualmente espaçados no vão de $122 \mathrm{~m}$ sobre o rio Pinheiros. Ao longo da altura, o espaçamento dos dois lados é constante, ocupando os $2 / 3$ superiores da altura do mastro.

Cada estai é compostos por cordoalhas de 15,7 $\mathrm{mm}$ de diâmetro, numa quantidade que varia de 33 a 55 cordoalhas galvanizadas, acondicionadas por 
extrusão no interior da bainha de polietileno de alta densidade, injetadas com cera de petróleo. O comprimento dos estais varia de $21,0 \mathrm{~m}$ a $120,0 \mathrm{~m}$ no vão sobre o rio Pinheiros, e de 21,5m a 93,0 m nos vãos sobre o solo.

O tabuleiro principal, de concreto protendido, foi executado através do método dos balanços sucessivos (figura 3.8).

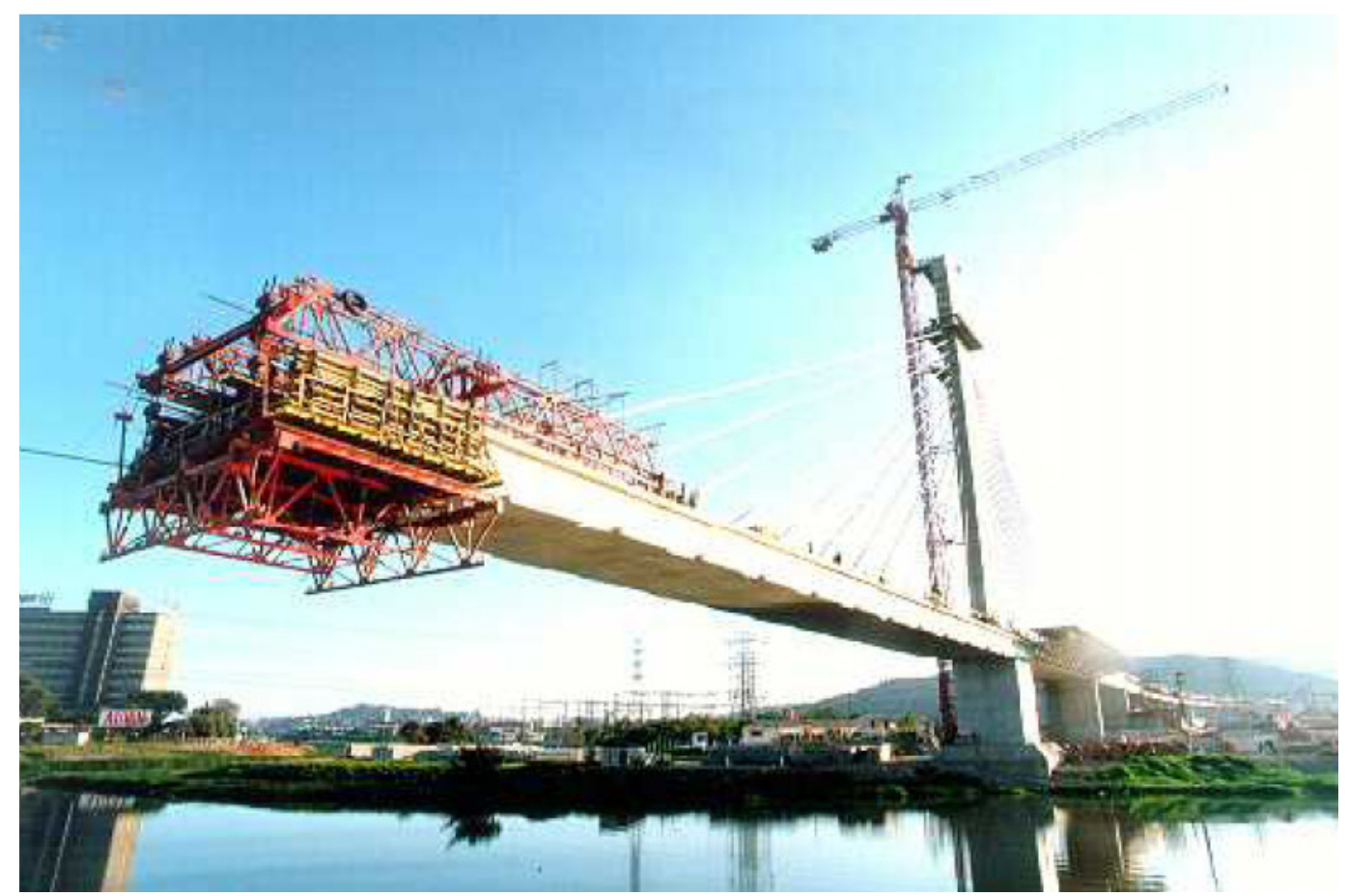

Figura 3.8 - Execução do tabuleiro da ponte (OAS, 1999 apud SANTOS, 2008) 


\subsection{VIADUTO MARIO COVAS}

O Viaduto Mario Covas foi idealizado para se tornar um cartão postal para a Baixada Santista, nas palavras de Irineu Meireles, presidente da Ecovias. O projeto estrutural foi executado pela Outec Engenharia, sob a responsabilidade dos engenheiros Rui Nobhiro Oyamada, Tunehiro Uono, Andrea Akemi Yamasaki e Hideki Ishitani. Também estiveram envolvidas no projeto as empresas EBEC (Engenharia Brasileira de Construções) e PROTENDE.

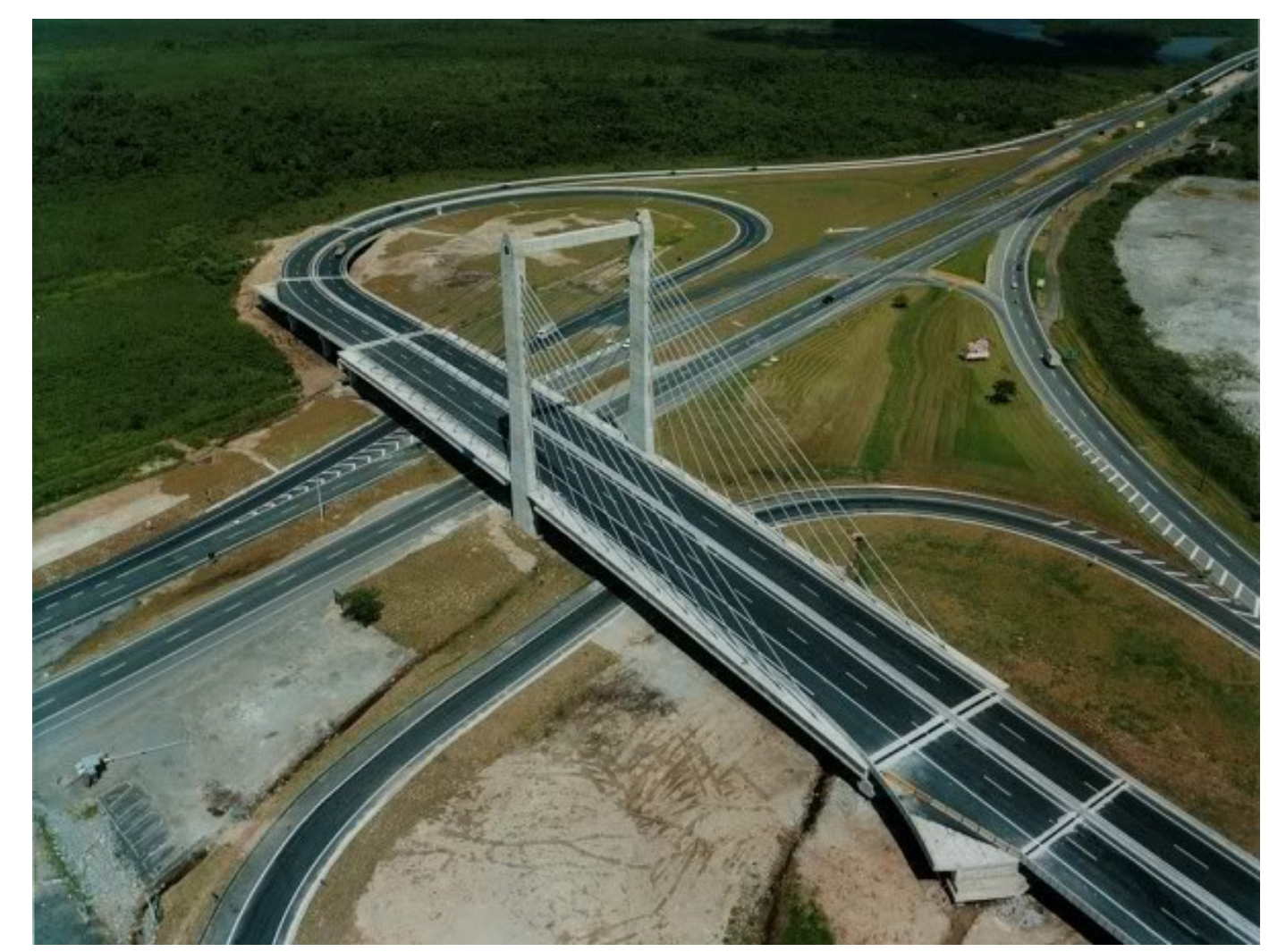

Figura 3.9 - Viaduto Mario Covas (http://engenhariacivildauesc.blogspot.com/2010/10/pontesestaiadas-no-brasil.html)

O prazo para a execução das obras era de seis meses, com o intuito de inaugurar o viaduto em dezembro de 2002, juntamente com o complexo de obras na rodovia, que dá acesso à Baixada Santista e demais cidades do litoral.

Além do prazo para execução da obras, outros pontos importantes deveriam ser observados no empreendimento, tais como: inovação tecnológica, respeito ao meio ambiente e aspecto estético agradável. 


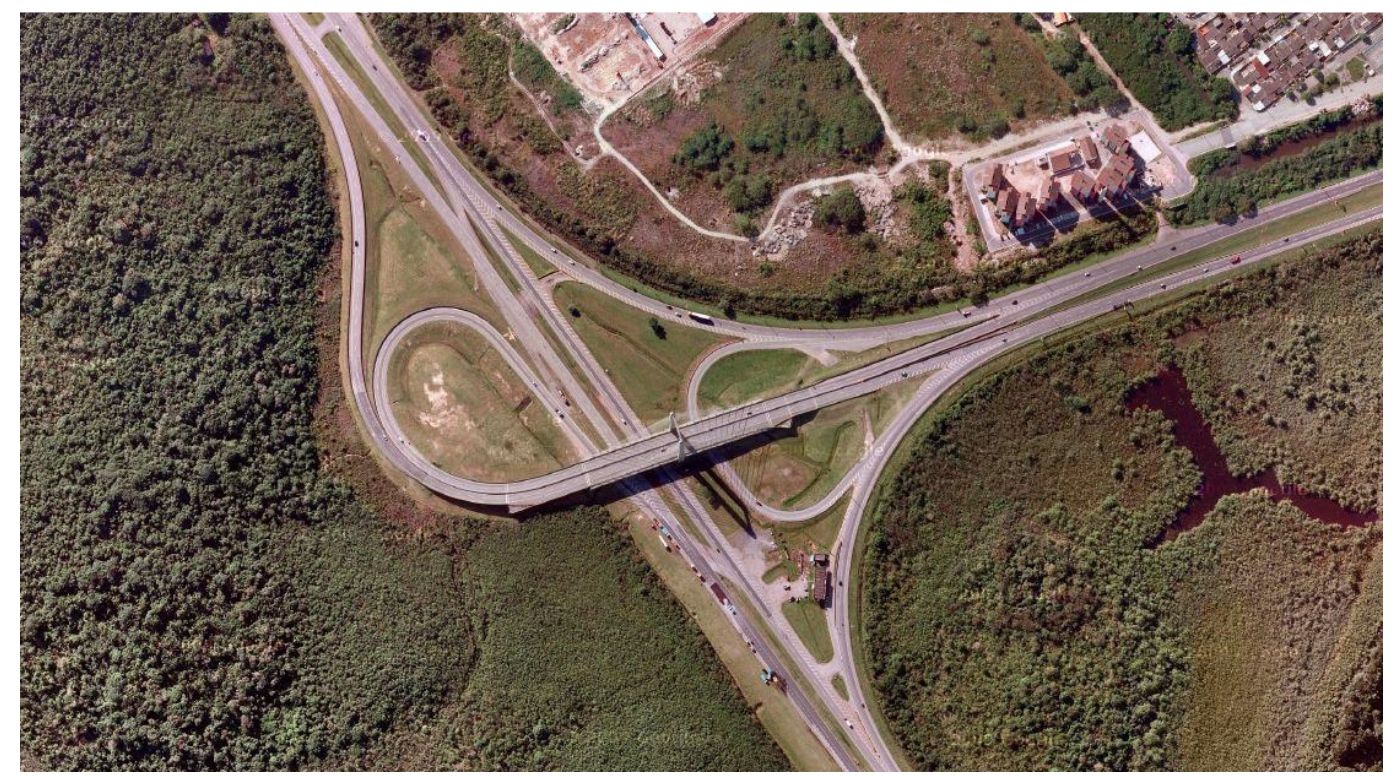

Figura 3.10 - Vista de Satélite do Viaduto Mario Covas (Google Maps)

O projeto básico da ponte previa um tabuleiro composto por longarinas prémoldadas e transversinas e lajes moldadas no local. Esta solução seria uma estrutura comum, em grelha com vãos isostáticos de 44 metros.

Porém, pelo prazo e pela necessidade de não haver pontos de interferência com a rodovia, optou-se por um novo arranjo estrutural em viaduto estaiado. Esta solução se apresentou mais viável, por não interferir significativamente na rodovia, e pelo ponto de vista estético.

Para que esta solução fosse possível, a geometria do tabuleiro foi revisada, utilizando-se elementos pré-moldados e técnicas de lançamento durante a construção do viaduto, com o intuito de evitar a interrupção do tráfego da rodovia.

Os estais estão dispostos em dois planos verticais simétricos, com geometria em semi-harpa.

O tabuleiro de concreto protendido possui uma largura constante de 27,8 m e comprimento total de $360 \mathrm{~m}$. O trecho estaiado da ponte corresponde a $85 \mathrm{~m}$ de cada lado do mastro.

O mastro de seção variável de concreto armado possui uma altura de $56 \mathrm{~m}$ acima do solo. 


\subsection{PONTE SERGIO MOTTA}

A Ponte Sergio Motta, localizada em Cuiabá, no Mato Grosso, foi inaugurada no ano de 2002, ligando os grandes conglomerados populacionais de Várzea Grande e Cristo Rei.

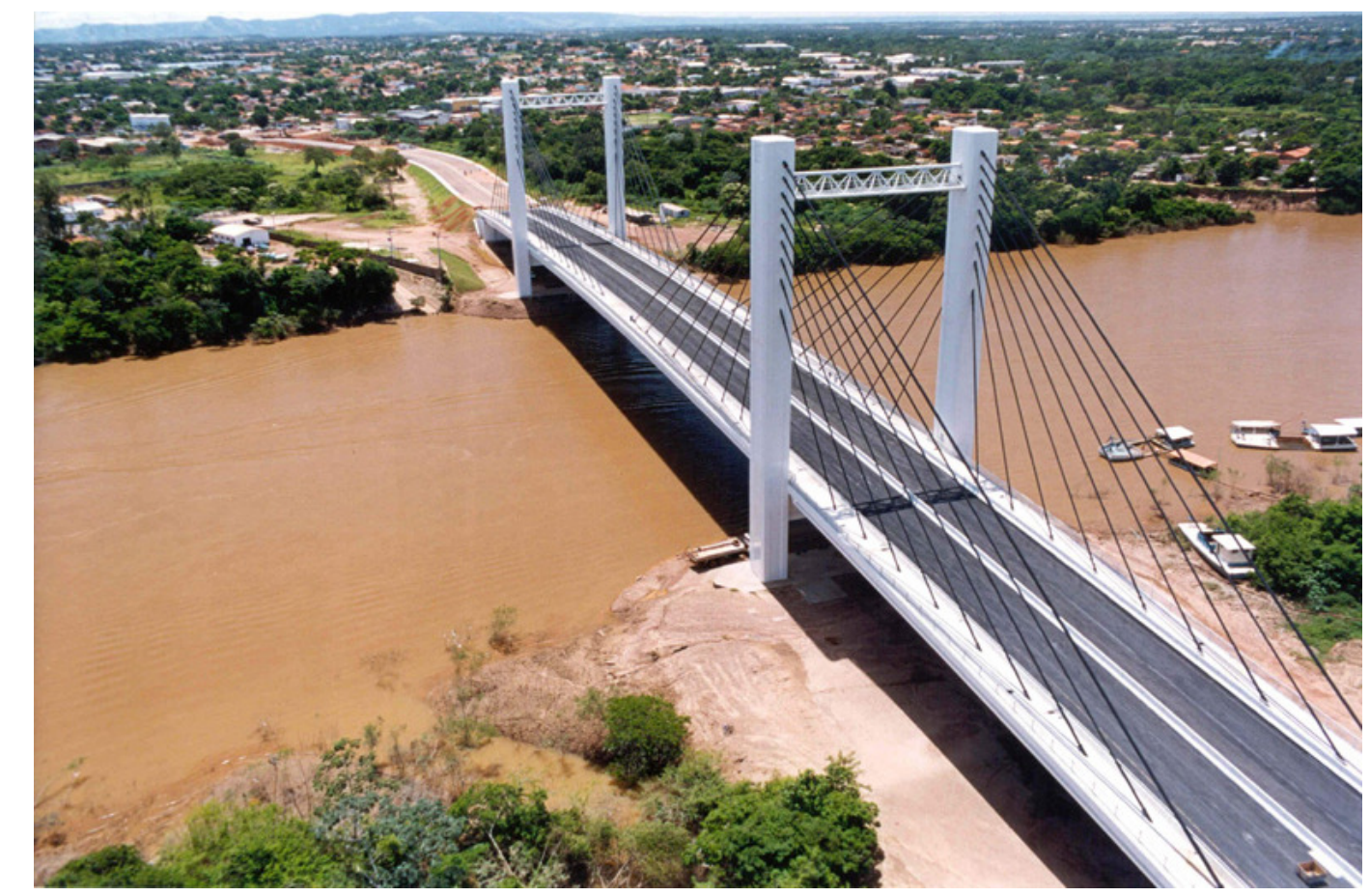

Figura 3.11 - Ponte Sergio Motta (http://www.skyscrapercity.com/showthread.php?p=43309078)

O tabuleiro de concreto protendido possui $312 \mathrm{~m}$ de extensão e $22,0 \mathrm{~m}$ de largura, sustentado por dois planos verticais de estaiamento, com geometria em semi-harpa, ancorados nos mastros de $52 \mathrm{~m}$ de altura.

O investimento para a construção desta ponte foi de 15 milhões de reais. 


\subsection{PONTE GUAMÁ}

A Ponte Guamá, sobre o Rio Guamá, foi concluída em dezembro de 2002 e faz parte de um conjunto de obras para da Alça Rodoviária, do Sistema de Integração do Pará, com o intuito de melhorar o transporte e o desenvolvimento da região.

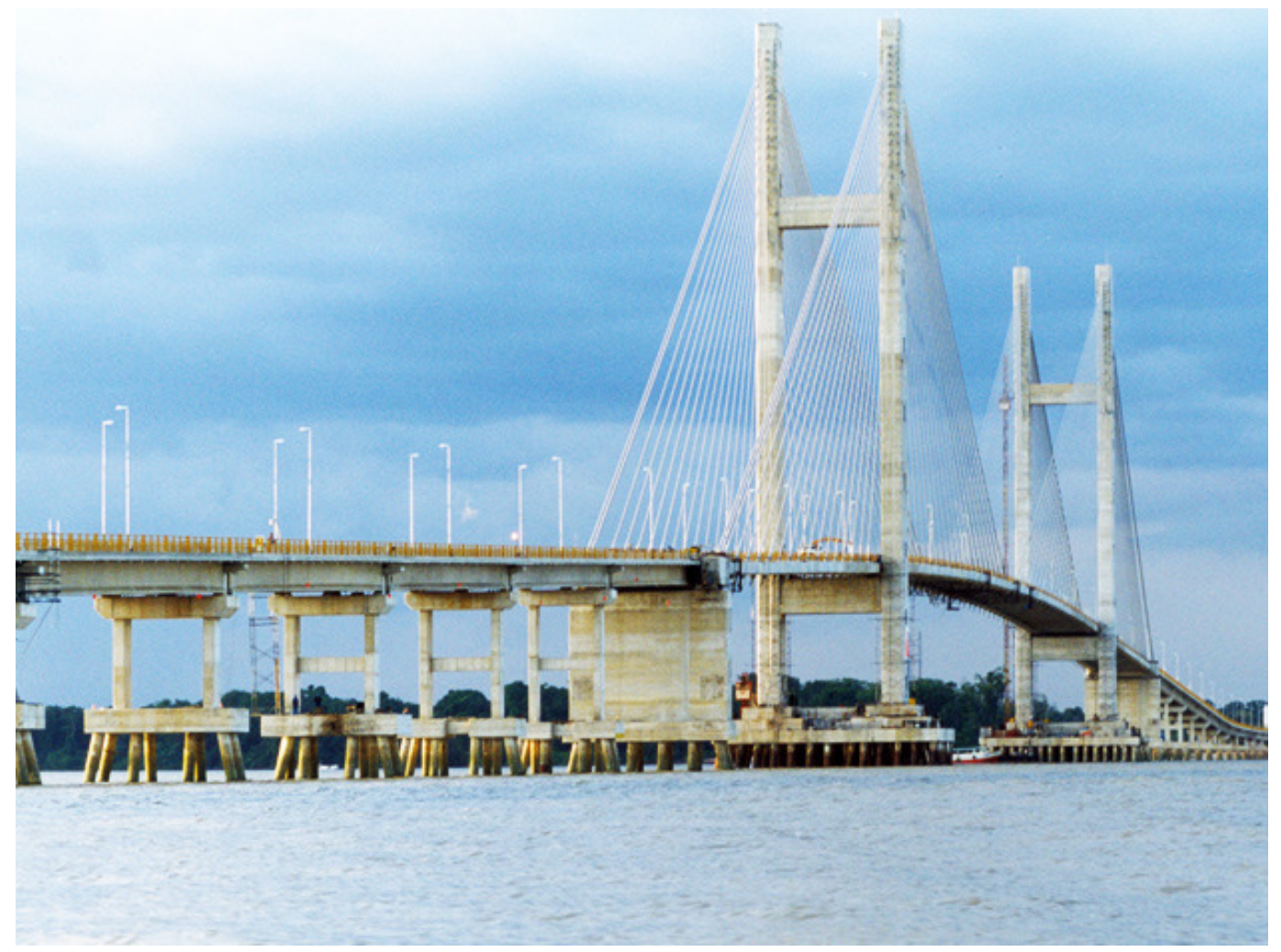

Figura 3.12 - Ponte Guamá (http://www.construbase.com.br/areas-de-atuacao/construcoes/ponteguama.php)

A ponte possui uma extensão total de $1976,8 \mathrm{~m}$, sendo que o trecho estaiado possui $582,4 \mathrm{~m}$ e os $1394 \mathrm{~m}$ restantes foram executados com vigas pré-moldadas de concreto. O tabuleiro de concreto, que possui uma largura constante de 12,4 m, é sustentado por 152 estais dispostos em dois planos verticais de estaiamento, com geometria de semi harpa. O vão estaiado principal desta ponte é de $320 \mathrm{~m}$. 


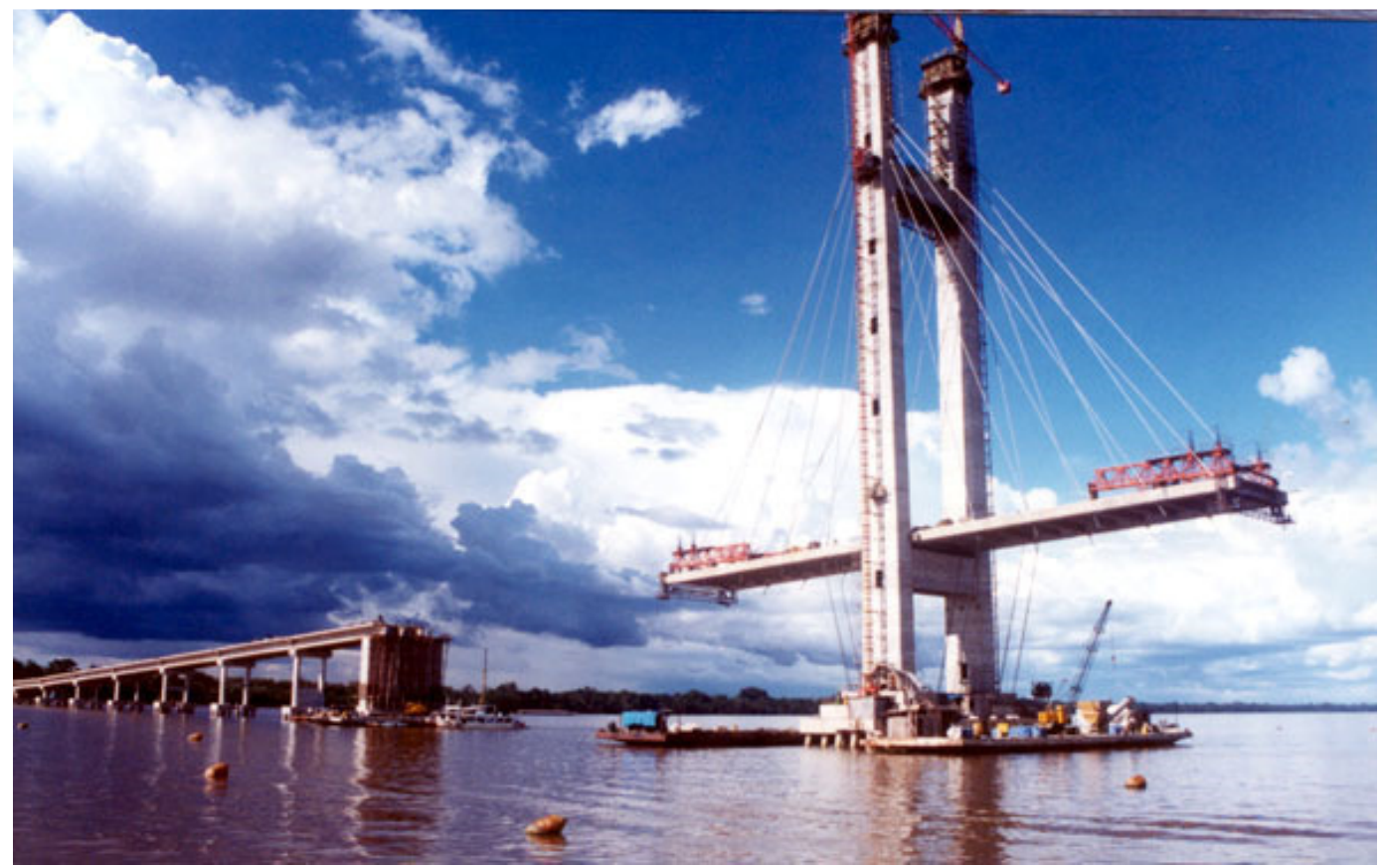

Figura 3.13 - Construção do trecho estaiado da Ponte Guamá (http://www.setran.pa.gov.br)

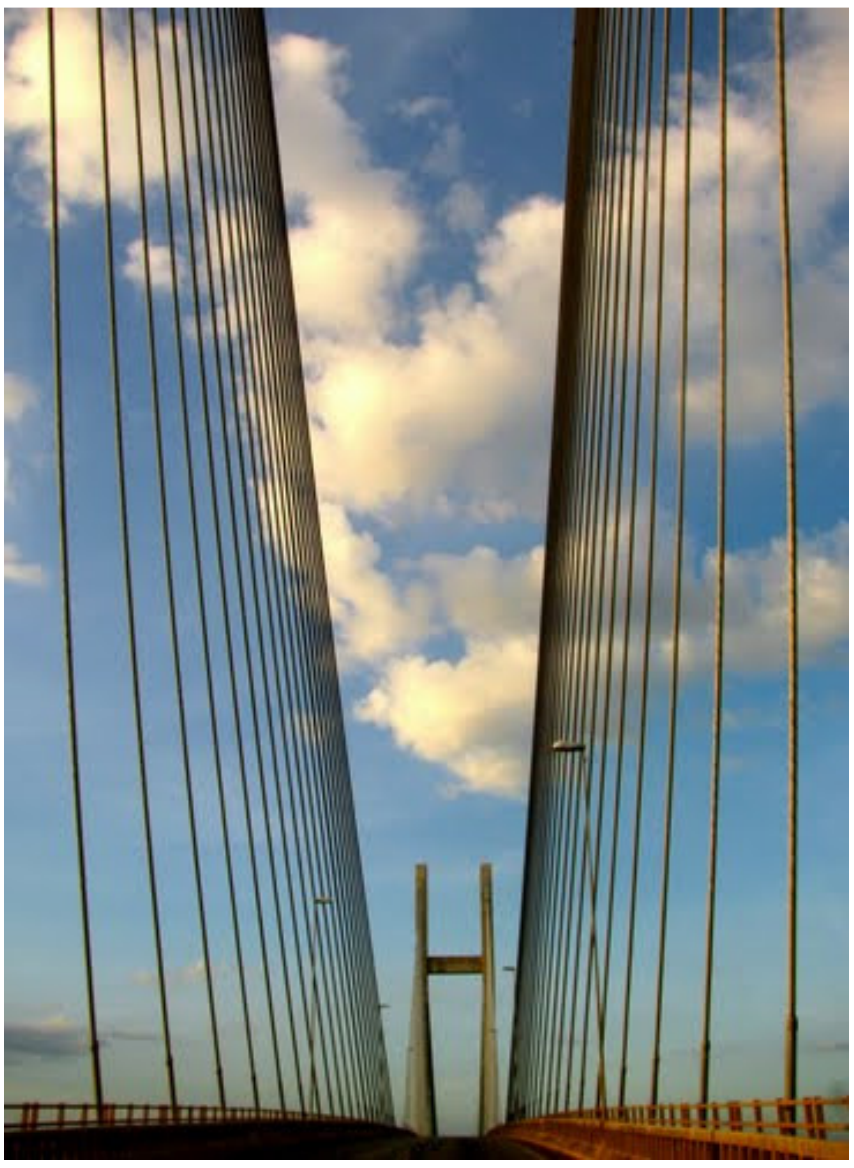

Figura 3.14 - Vista dos estais da Ponte Guamá (http://www.panoramio.com/photo/43146477) 


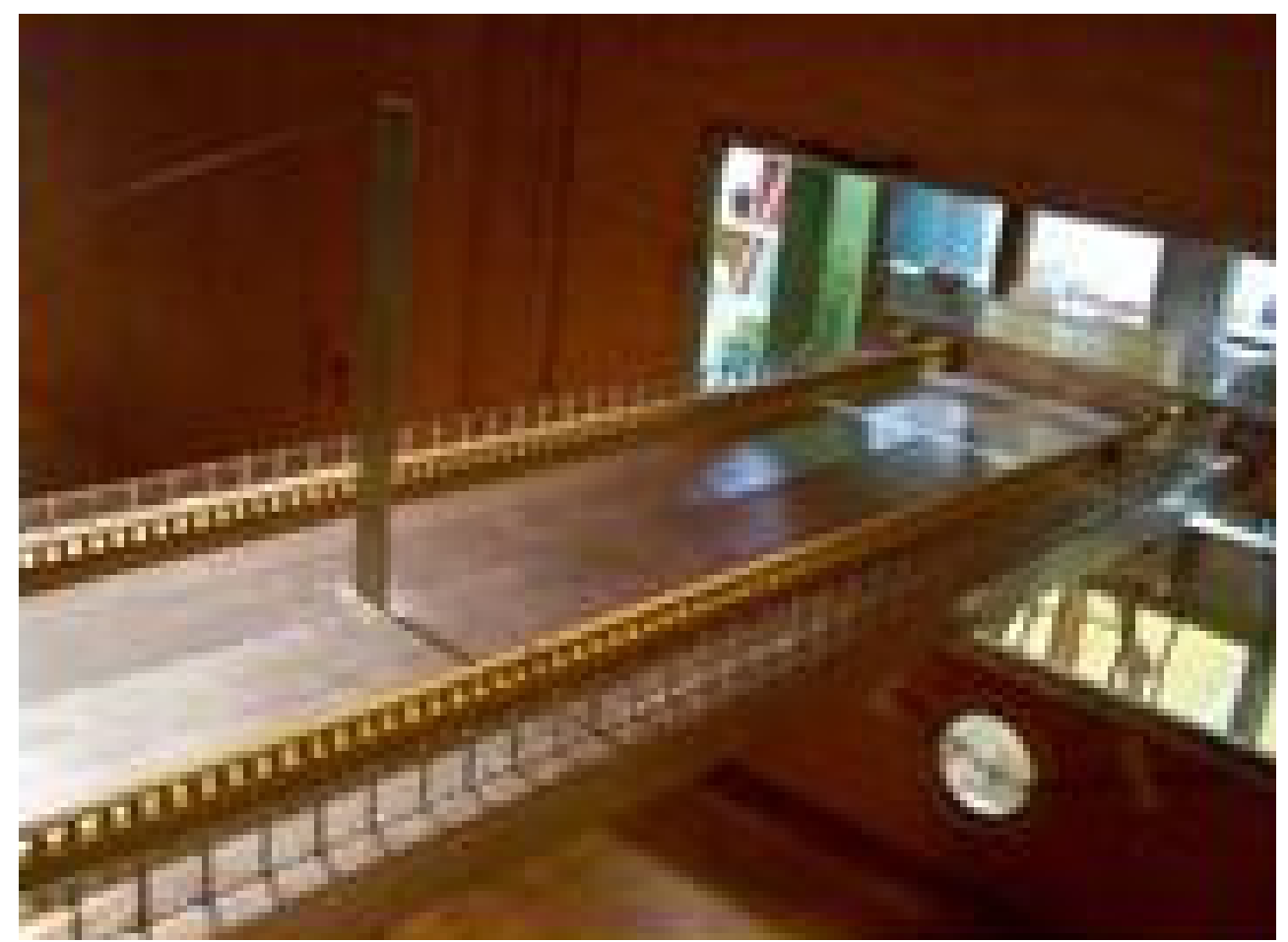

Figura 3.15 - Modelo do tabuleiro ensaiado em túnel de vento no Laboratório de Aerodinâmica das Construções da UFRGS (http://www.ufrgs.br/lac/consultorias/sp_pauliceia.htm) 


\subsection{PONTE DE INTEGRAÇÃO BRASIL - PERU}

Construída de 2004 a 2005, a Ponte de Integração Brasil - Peru faz parte do projeto, do governo federal brasileiro, de integração do Brasil com a America do Sul. Localizada no Acre, a ponte faz a ligação do município de Assis no Brasil a Inâpari no Peru.

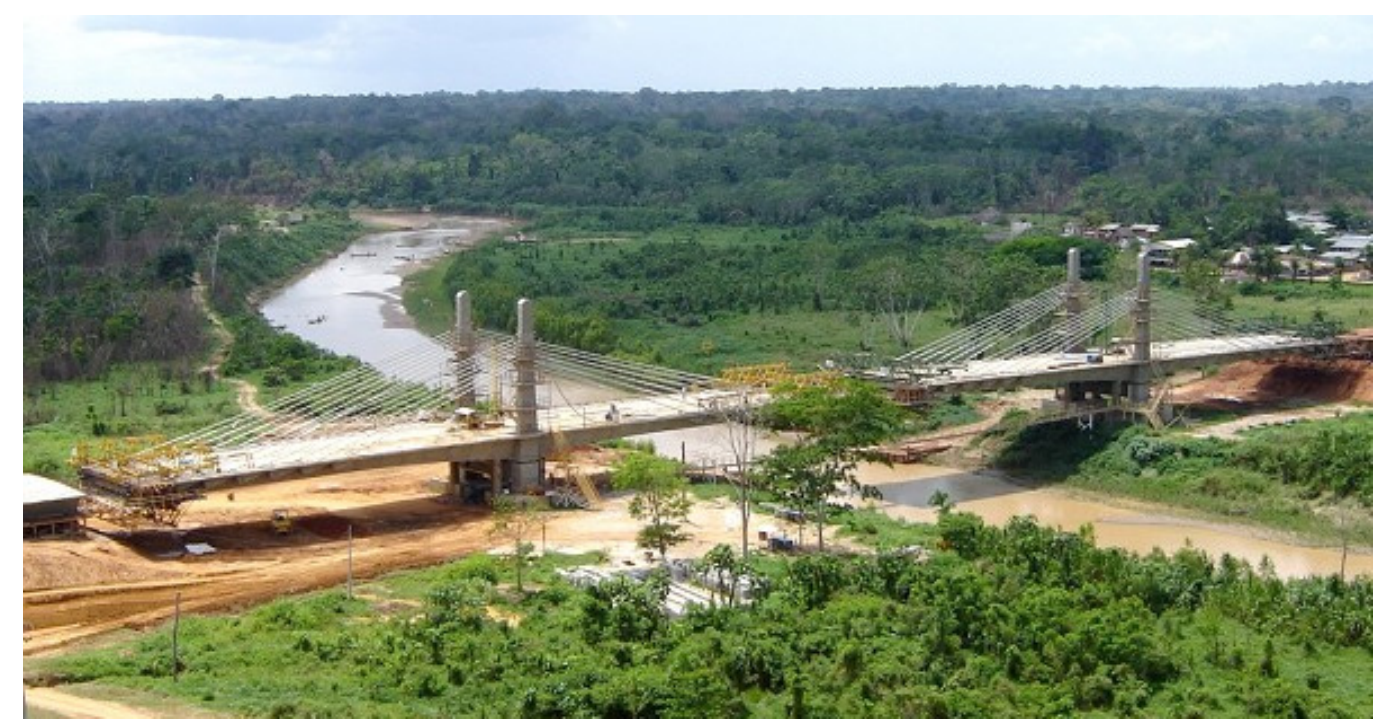

Figura 3.16 - Ponte de Integração Brasil - Peru (http://en.structurae.de/photos/index.cfm?JS=50670)

O projeto estrutural foi executado pela Outec Engenharia, sob a responsabilidade dos engenheiros Rui Nobhiro Oyamada, Tunehiro Uono, Iberê Martins da Silva, Viviane Marta Tanizaki e Hideki Ishitani. Também estiveram envolvidas no projeto as empresas Construtora Cidade e Editec.

Os estais estão dispostos em dois planos verticais simétricos, com geometria em extradorso. Esta ponte foi a primeira ponte extradorso inaugurada no Brasil.

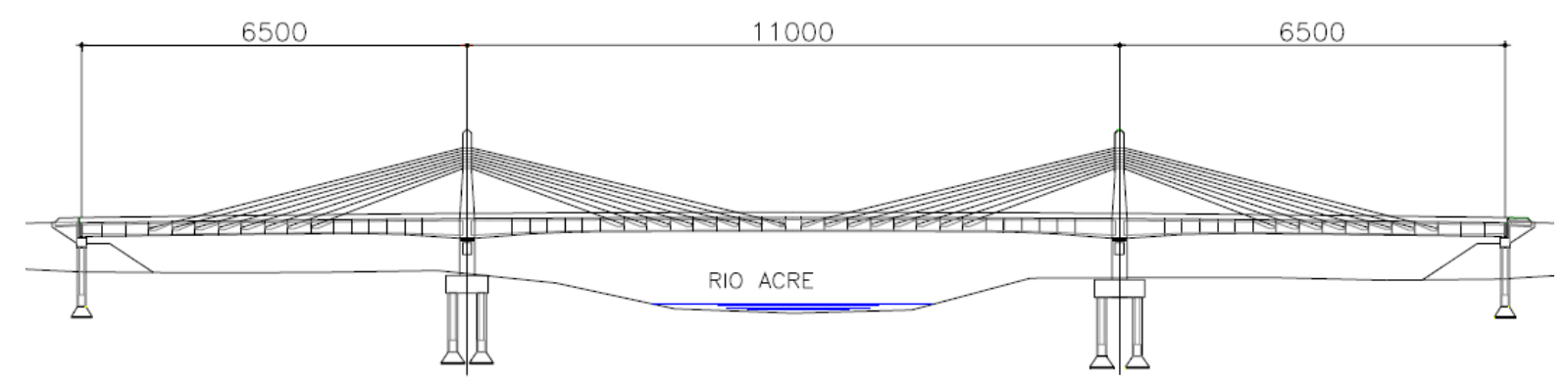

Figura 3.17 - Corte Longitudinal da Ponte de Integração Brasil - Peru (ISHII, 2006, p.24) 


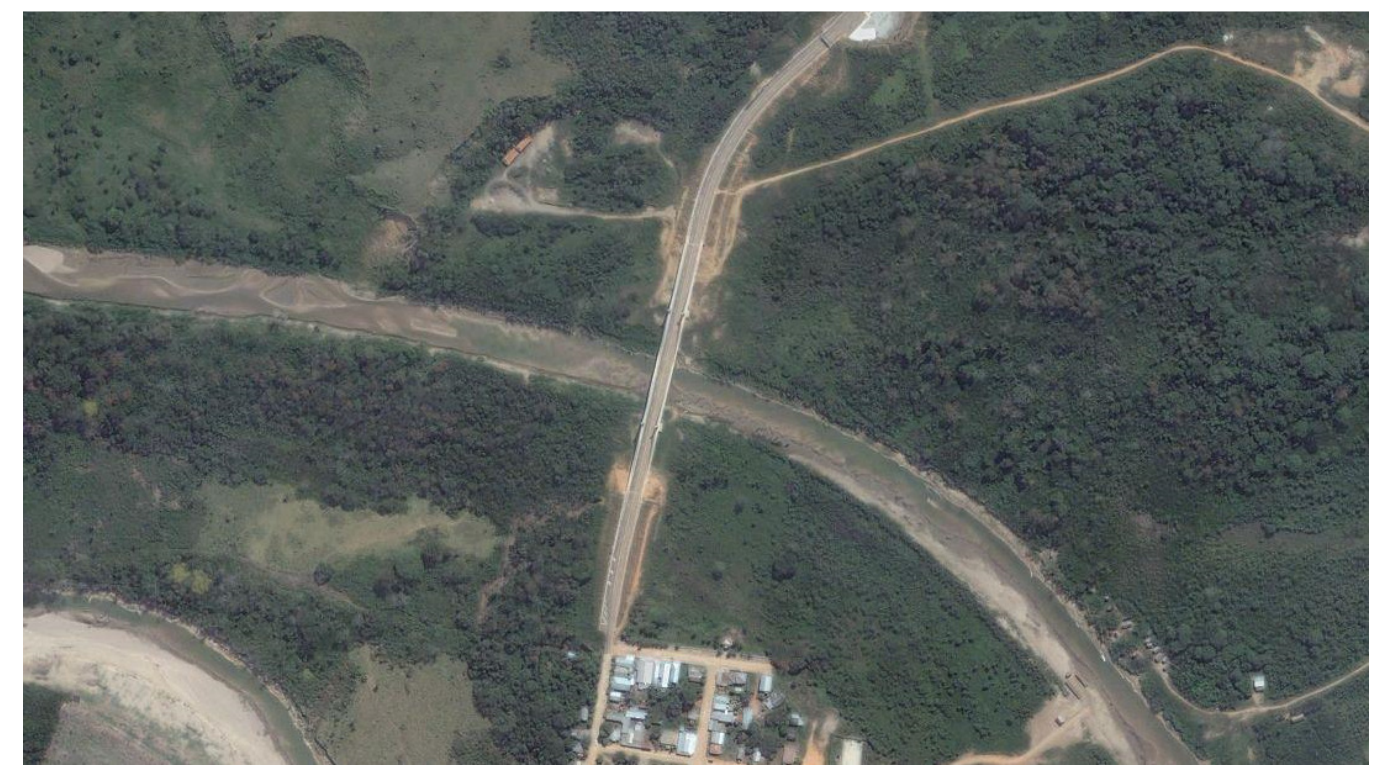

Figura 3.18 - Vista de Satélite da Ponte de Integração Brasil Peru (Google Maps)

O tabuleiro de concreto protendido possui uma largura constante de 16,8 m e comprimento total de $240 \mathrm{~m}$, sendo o vão central de $110 \mathrm{~m}$ e os laterais de $65 \mathrm{~m}$. Sua espessura é variável de 2,35 m no centro do vão principal a 3,35 m na região dos apoios intermediários.

O mastro de seção variável de concreto armado possui uma altura de 22,5 m acima da cota de assentamento.

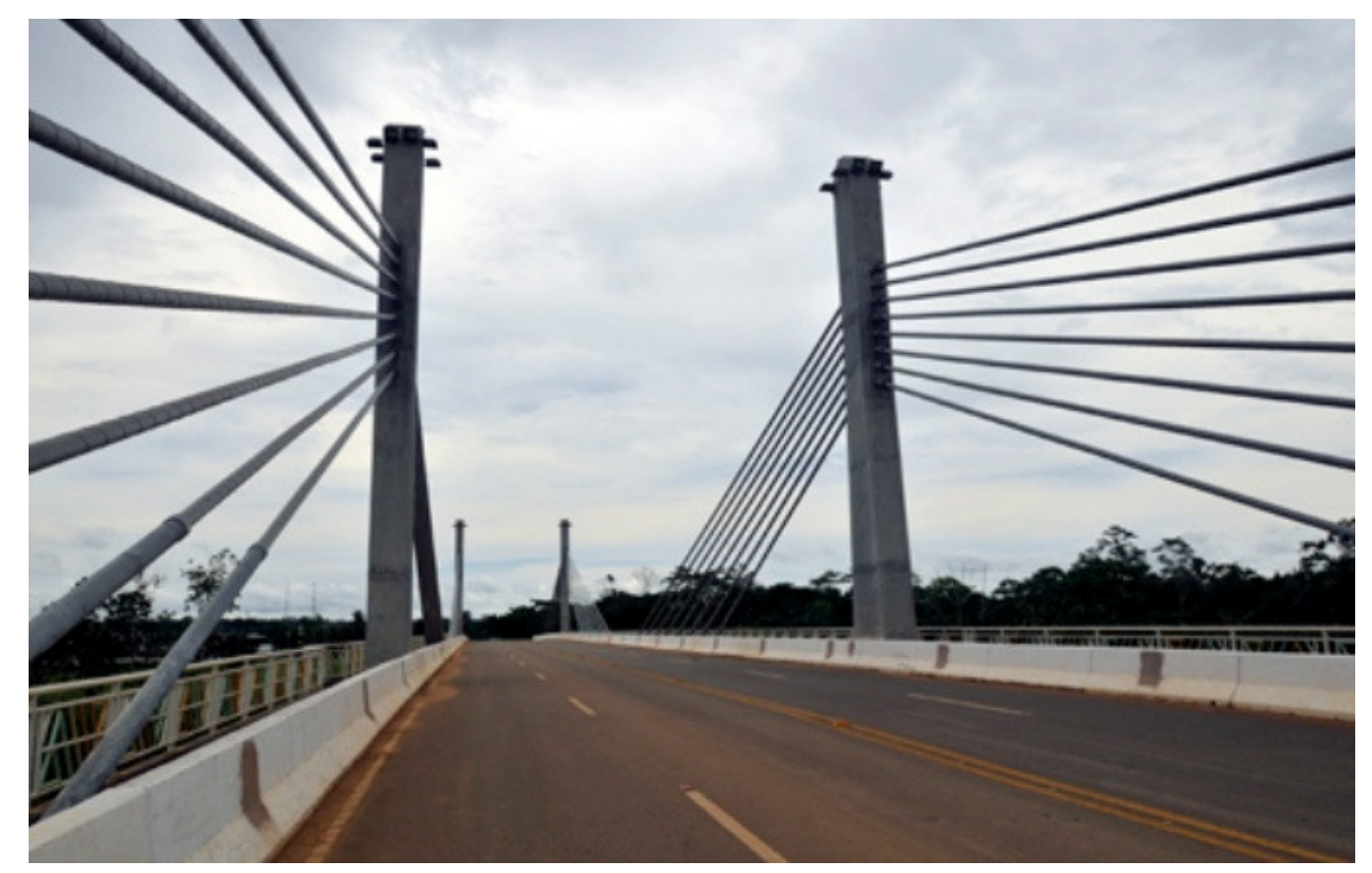

Figura 3.19 - Vista dos Estais da Ponte de Integração Brasil Peru (http://www.flickr.com/photos/jurandir_lima/5268957956/) 


\subsection{TERCEIRA PONTE DO RIO BRANCO}

A Terceira Ponte do Rio Branco atravessa o Rio Acre, na cidade de Rio Branco no Acre, e faz parte do anel viário da cidade.

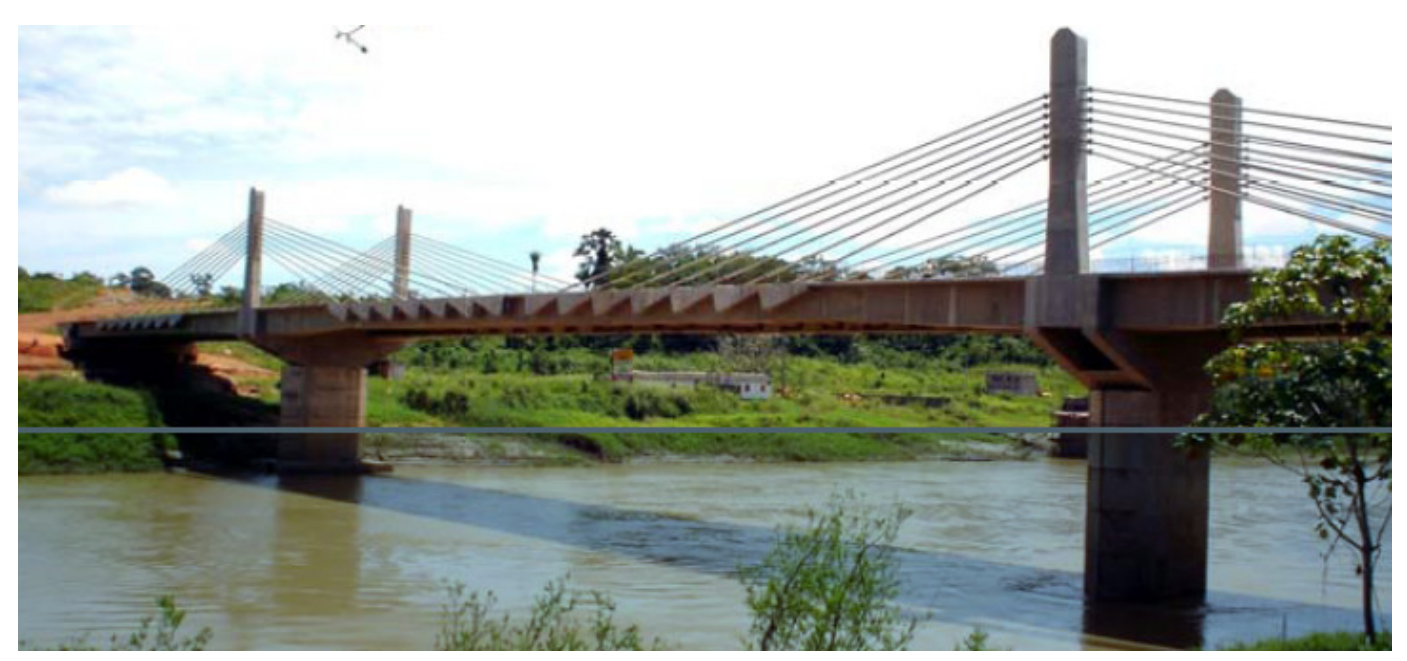

Figura 3.20 - Terceira Ponte do Rio Branco (http://www.ccidade.com.br/terceira.htm)

Esta ponte é mais uma representante das pontes extradorso, sendo a segunda construída no Brasil. Seu comprimento total é de $198 \mathrm{~m}$, sendo o vão central de $90 \mathrm{~m}$. Os estais são dispostos em dois planos verticais de estaiamento, que dão suporte ao tabuleiro de 21,1 m de largura, com capacidade para 4 faixas de tráfego. Os mastros de concreto possuem apenas $12 \mathrm{~m}$ de altura. Sua inauguração foi no ano de 2006.

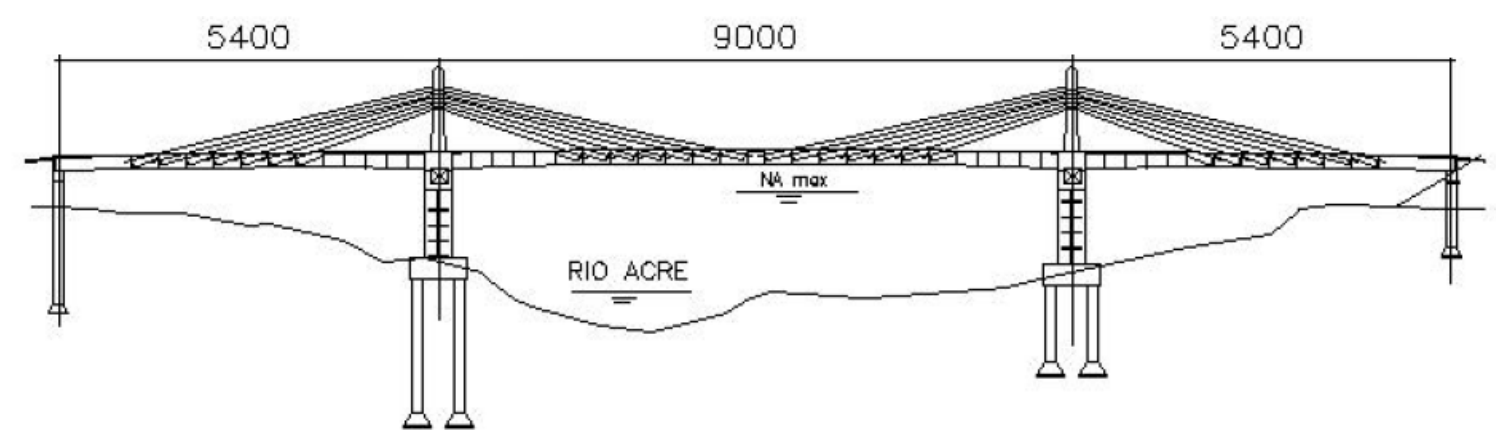

Figura 3.21 - Corte longitudinal da Terceira Ponte do Rio Branco (ISHII, 2006, p.21)

O custo da execução da ponte foi de 16 milhões de reais, e foi construída pelas empresas SEC e Construtora Cidade. O projeto da ponte foi executado pela OUTEC Engenharia de Projetos. 


\subsection{PONTE CONSTRUTOR JOÃO ALVES}

A Ponte Construtor João Alves, também conhecida como Ponte Aracaju Barra dos Coqueiros, liga a cidade de Aracaju ao município de Barra dos Coqueiros, no Sergipe. Sua construção teve inicio no ano de 2004, e foi inaugurada no dia 24 de setembro de 2006.

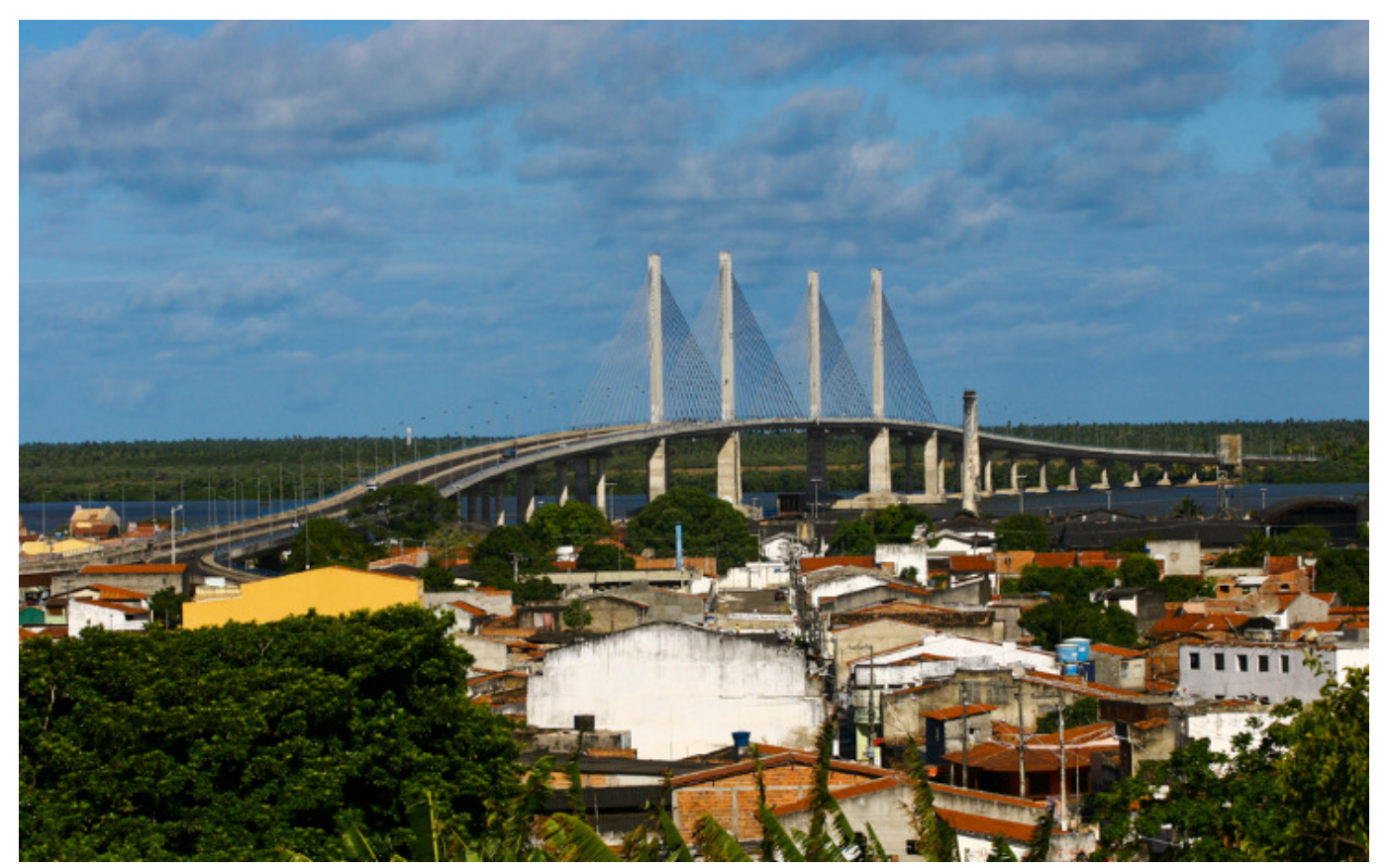

Figura 3.22 - Ponte Construtor João Alves (http://www.flickr.com/photos/rbpdesigner/4319333796)

O tabuleiro de 21,3 m de largura, é suportado por dois planos verticais de estaiamento, em geometria semi harpa. O vão central estaiado da ponte é de $200 \mathrm{~m}$. Este tabuleiro é uma estrutura mista de concreto protendido e vigas metálicas.

O projeto básico da ponte foi do engenheiro italiano Mario de Miranda e da EGT Engenharia, e o projeto executivo pela OUTEC Engenharia de Projetos. A construção ficou sob a responsabilidade da Empresa Sul Americana de Montagens S/A (EMSA) 


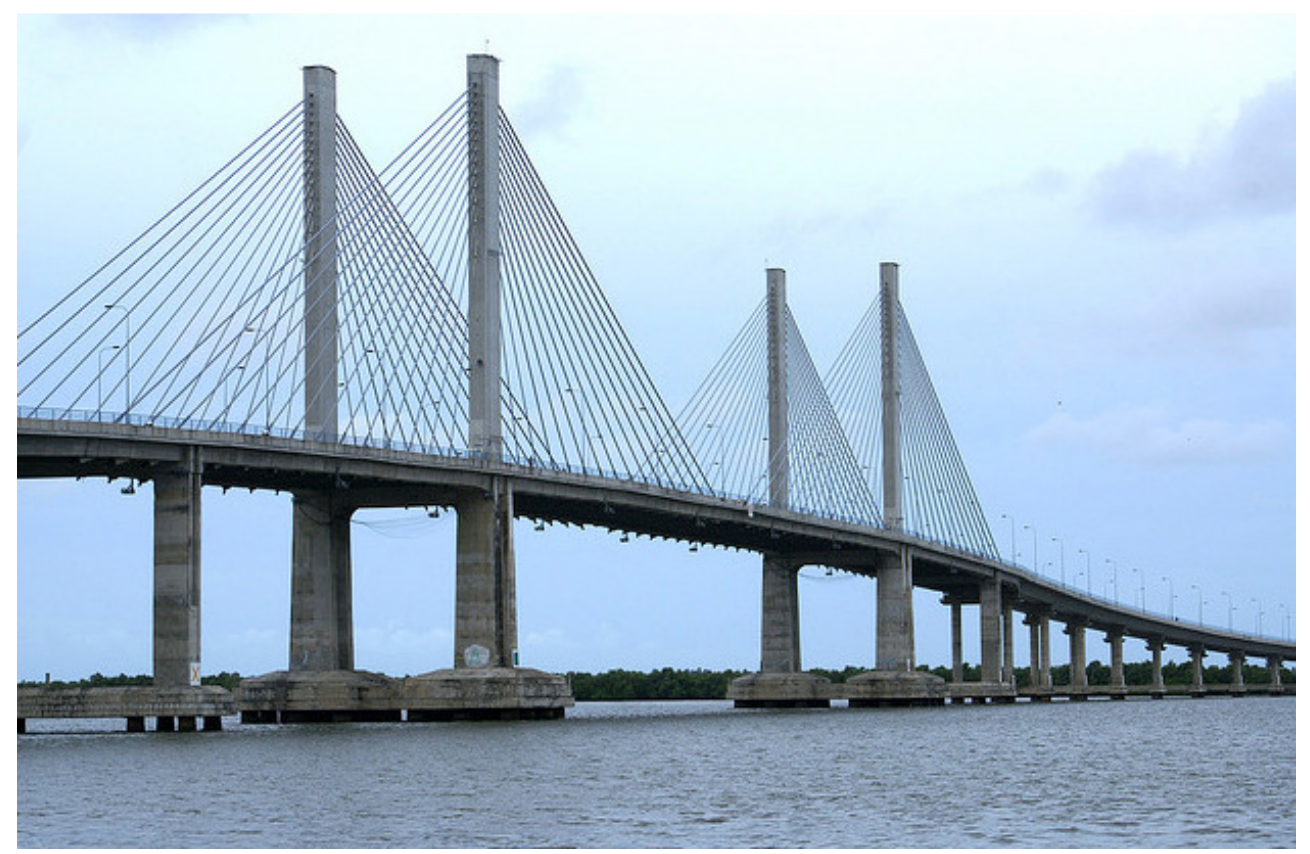

Figura 3.23 - Ponte Construtor João Alves (http://www.flickr.com/photos/9738273@N06/4206594475)

O custo total para a execução da Ponte Construtor João Alves foi de 99 milhões de reais, e ela trouxe benefícios às cidades da região, facilitando o fluxo de pessoas e mercadorias.

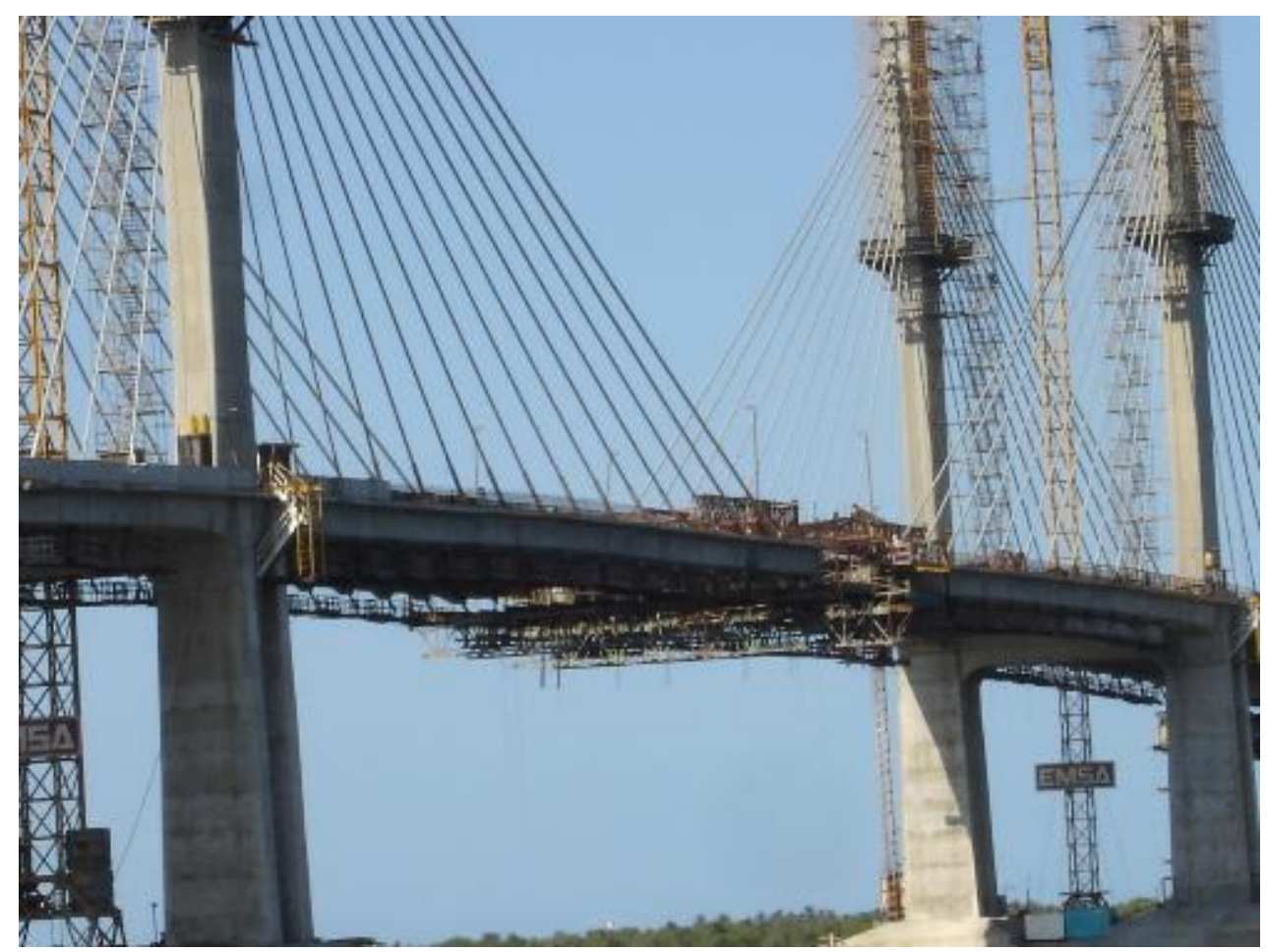

Figura 3.24 - Construção do trecho estaiado da Ponte Construtor João Alves (http://www.skyscrapercity.com/showthread.php?t=398599) 


\subsection{PONTE NEWTON NAVARRO}

Localizada em Natal, capital do estado do Rio Grande do Norte, a Ponte Newton Navarro também é conhecida como Ponte Forte-Redinha ou Ponte Nova, e faz a ligação entre os bairros da Zona Norte aos municípios da Zona Sul de Natal. A ponte se destaca pela sua elevada altura, e atualmente se tornou um ponto turístico e de referência para a cidade.

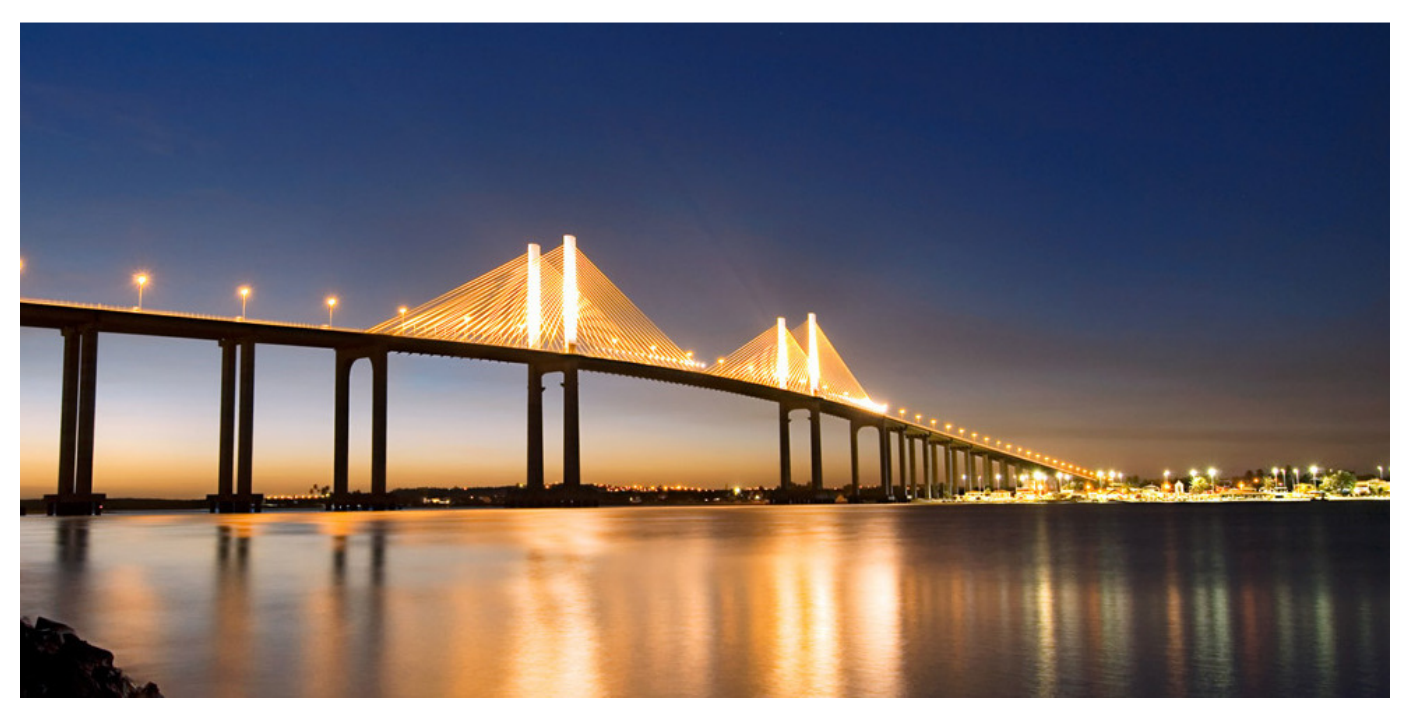

Figura 3.25 - Ponte Newton Navarro (http://riograndedonorte.org)

A ponte Newton Navarro foi construída com a finalidade de aliviar o tráfego da região, melhorar o acesso aos novos empreendimentos da região norte da cidade, sendo um deles o novo Aeroporto Internacional de São Gonçalo do Amarante, e melhorar o deslocamento dos turistas pela região.

O projeto foi executado através de uma parceria entre os engenheiros Alex Barros, Mario de Miranda, Carlos Fuganti e João Pereira. O trecho estaiado, com $400 \mathrm{~m}$ de extensão, foi projetado pelo italiano Mario de Miranda. Também participaram da obra as seguintes empresas: PROTENDE, ENESCIL, Construbase e Construtora Queiroz Galvão.

O tabuleiro de concreto protendido possui uma largura constante de $21 \mathrm{~m} \mathrm{e}$ comprimento total de $1780 \mathrm{~m}$, sendo que o vão central estaiado possui $400 \mathrm{~m}$ de extensão e está localizado a uma altura de $56 \mathrm{~m}$ do Rio Potengi.

O mastro de seção variável de concreto armado possui uma altura de 110,0 m acima da cota de assentamento da ponte. 


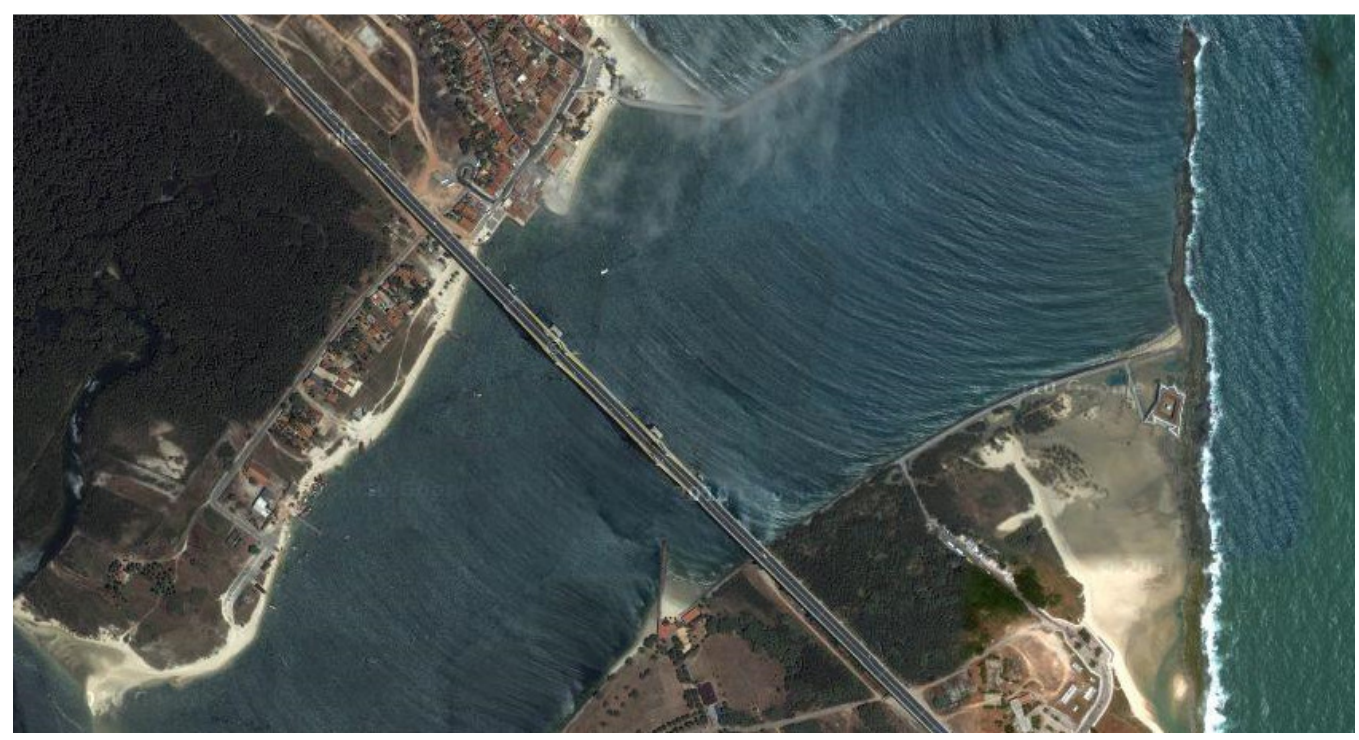

Figura 3.26 - Vista de Satélite da Ponte Newton Navarro (Google Maps)

O projeto inicial da ponte é de 1992, porém o projeto foi paralisado devido à falta de definições. O projeto só foi retomado 2003, quando o governo assumiu a responsabilidade pela obra.

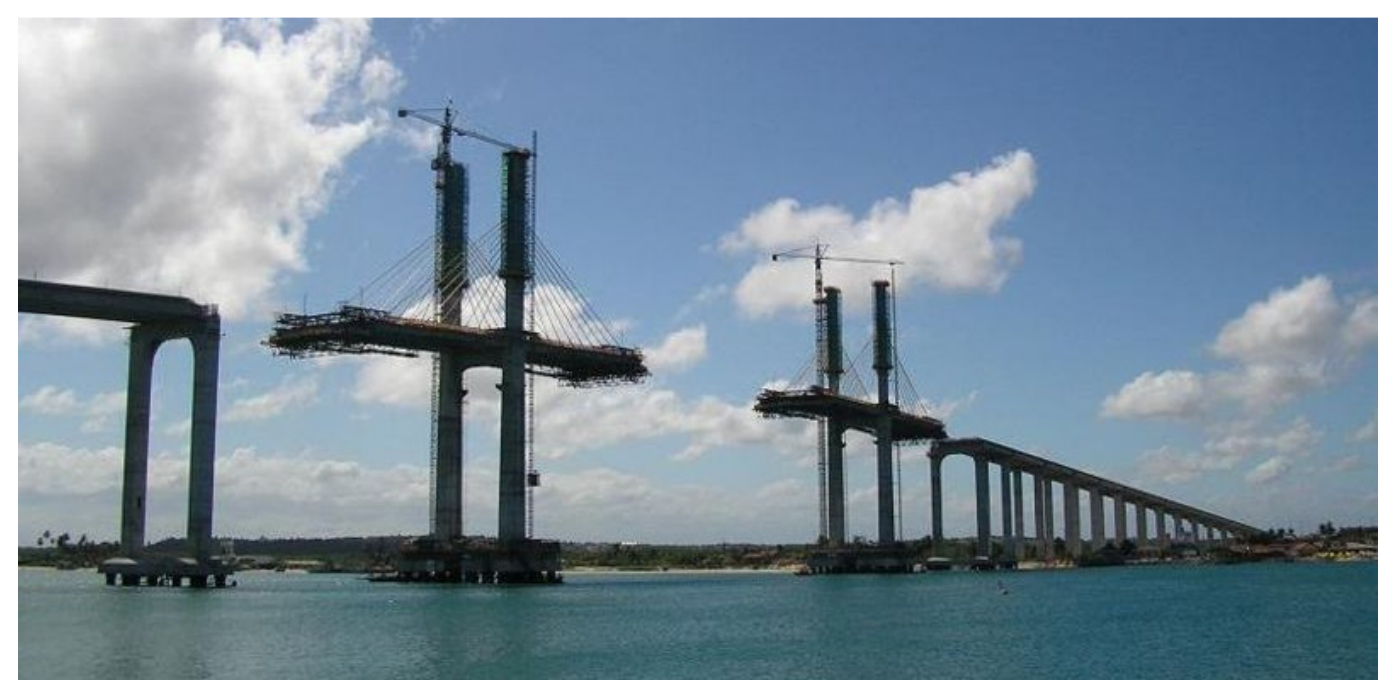

Figura 3.27 - Construção da Ponte Newton Navarro (http://pt.wikipedia.org/wiki/Ponte_Newton_Navarro)

As obras foram iniciadas no dia 24 de outubro de 2004, mas devido a diversos problemas financeiros e de desapropriação de terrenos, a obra demorou mais que o previsto e só foi inaugurada no dia 21 de novembro de 2007. A ponte, que possui uma capacidade de 60 mil veículos por dia, custou 195 milhões de reais. 


\subsection{PONTE OCTAVIO FRIAS DE OLIVEIRA}

A ponte Octavio Frias de Oliveira, localizada em São Paulo na altura no número 10.000 da Marginal Pinheiros, é atualmente a $13^{\text {a }}$ ponte a cruzar o Rio Pinheiros.

Antes da execução desta ponte estaiada, a travessia neste trecho da Marginal Pinheiros era feita através da ponte do Morumbi e da ponte Engenheiro Ari Torres. Porém, estes trajetos são mais longos que o oferecido por esta ponte, que liga a Avenida Jornalista Roberto Marinho às marginais de maneira mais eficiente e prática.

A ponte Octavio Frias de Oliveira foi dimensionada para um fluxo de 2.000 veículos por hora por faixa, totalizando 4.000 veículos por hora para cada sentido do fluxo.

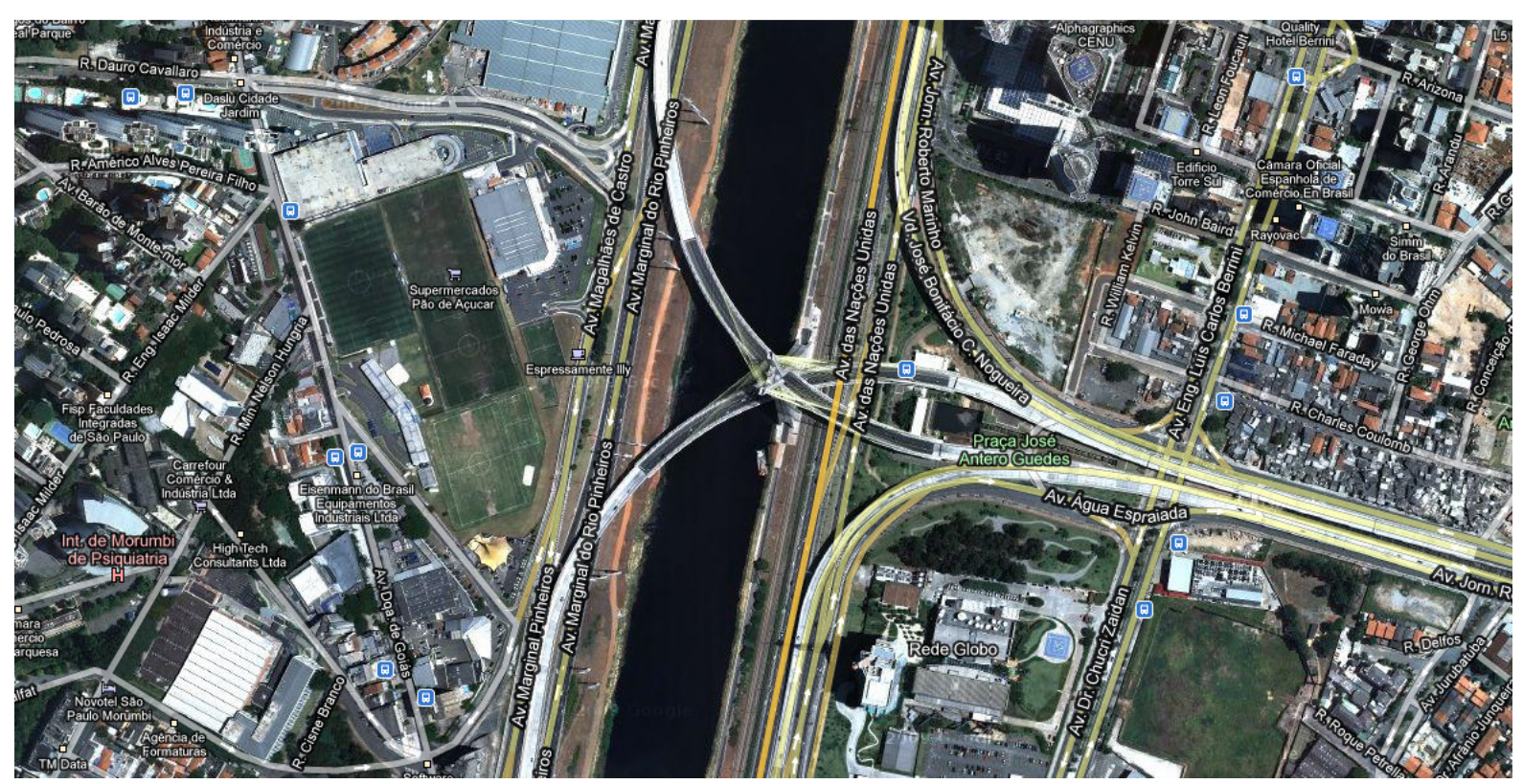

Figura 3.28 - Vista de satélite da Ponte Octavio Frias de Oliveira (Google Maps)

O projeto básico da EMURB, Empresa Municipal de Urbanização da Prefeitura de São Paulo, previa a construção de duas pontes estaiadas, localizadas uma ao lado da outra (figura 3.29). Porém, devido a diversos fatores que gerariam interferências visuais e técnicas nos arredores da construção, optou-se no projeto executivo pela construção de uma única ponte com dois tabuleiros (figura 3.30). 


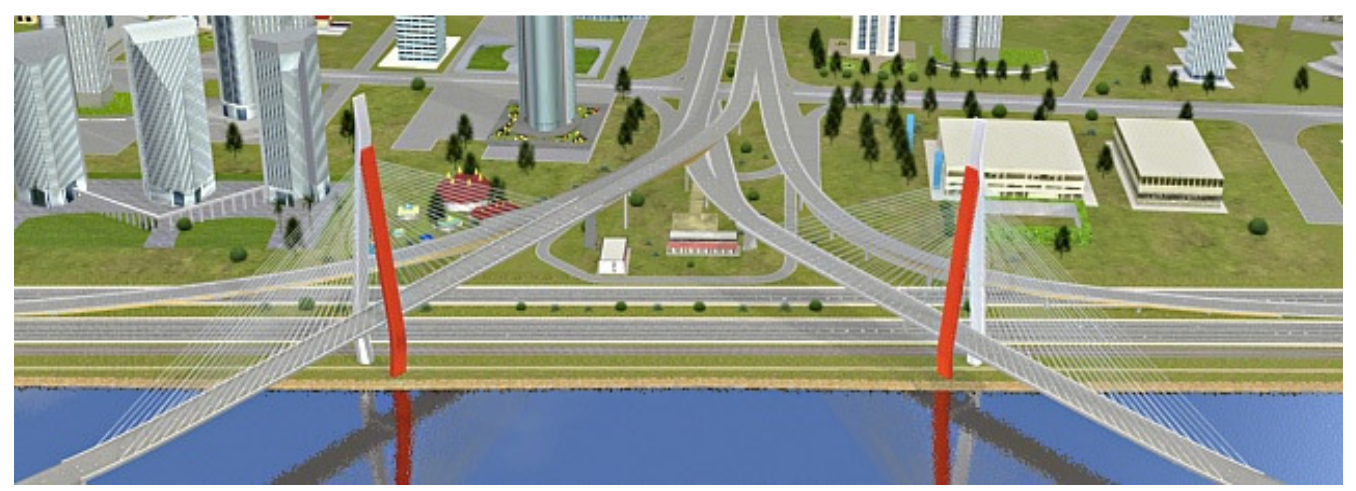

Figura 3.29 - Ilustração artística do Projeto Básico (RIBEIRO, Catão F. - Simpósio internacional sobre pontes e grandes estruturas, 2008)

Tendo em vista a geometria necessária para ligar as vias deste local, ambos os tabuleiros da ponte tiveram de ser executados em curva. Este fato tornou a Ponte Octavio Frias de Oliveira a primeira ponte estaiada do mundo com dois tabuleiros em curva sustentados por um único mastro.

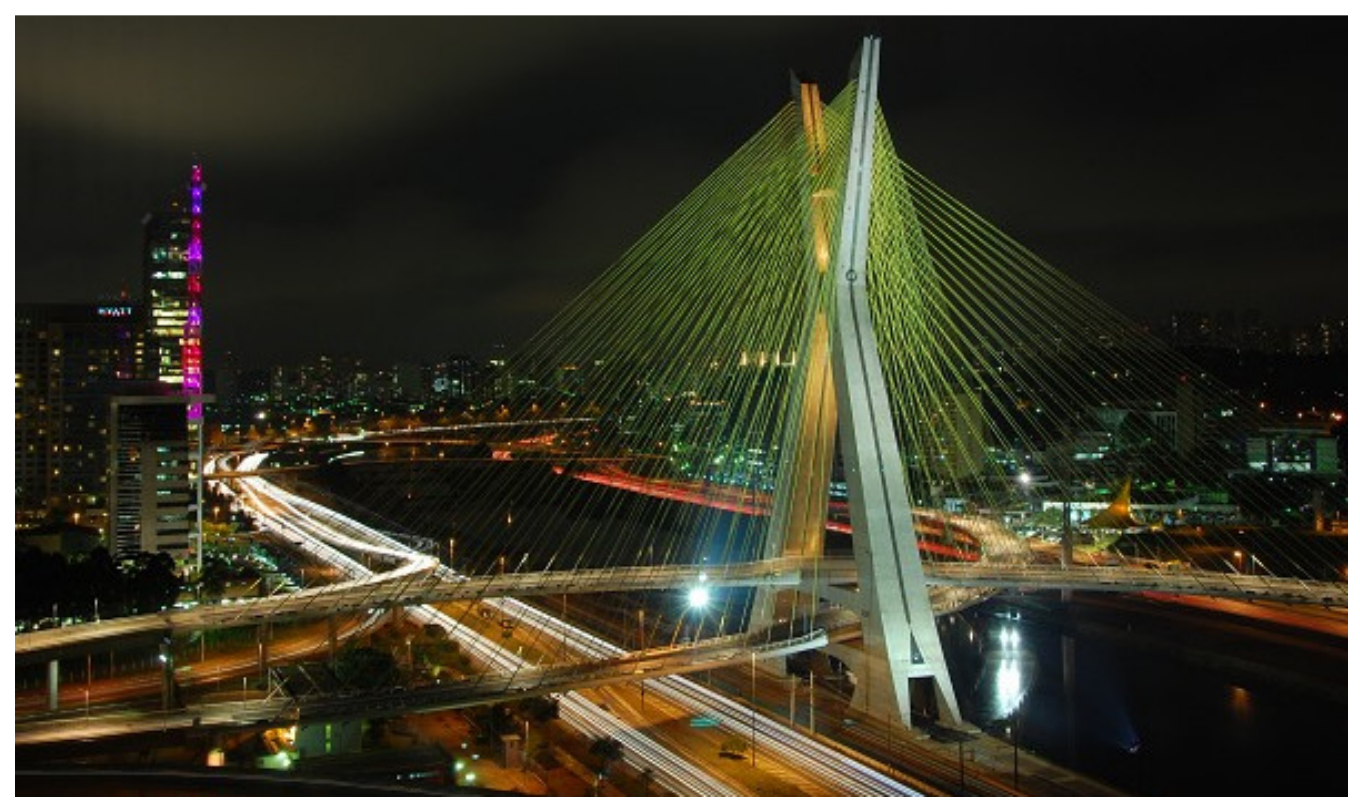

Figura 3.30 - Ponte Octavio Frias de Oliveira (http://en.structurae.de/photos/index.cfm?JS=170103)

Para que a utilização de um único mastro fosse tecnicamente viável, os tabuleiros foram projetados para cruzar o mastro em $X$ pelo seu centro, porém, em diferentes níveis altimetricos. Esta solução permitiu uma redução na área de intervenção de $40.000 \mathrm{~m}^{2}$ para $20.000 \mathrm{~m}^{2}$, uma vez que não haveria mais dois mastros. 
A ponte teve sua construção iniciada em 2005, e demorou 3 anos até a sua inauguração no dia 10 de maio de 2008.

A construção da ponte foi executada pela Construtora OAS e o projeto estrutural foi desenvolvido pelas empresas Enescil Engenharia e Projetos, ANTW Engenharia e Projetos e Antranig Muradian, sendo a responsabilidade dos engenheiros Catão Francisco Ribeiro, Heitor Afonso Nogueira Neto e Antranig Muradian. Nesta obra trabalharam cerca de 420 funcionários se revezando em dois turnos.

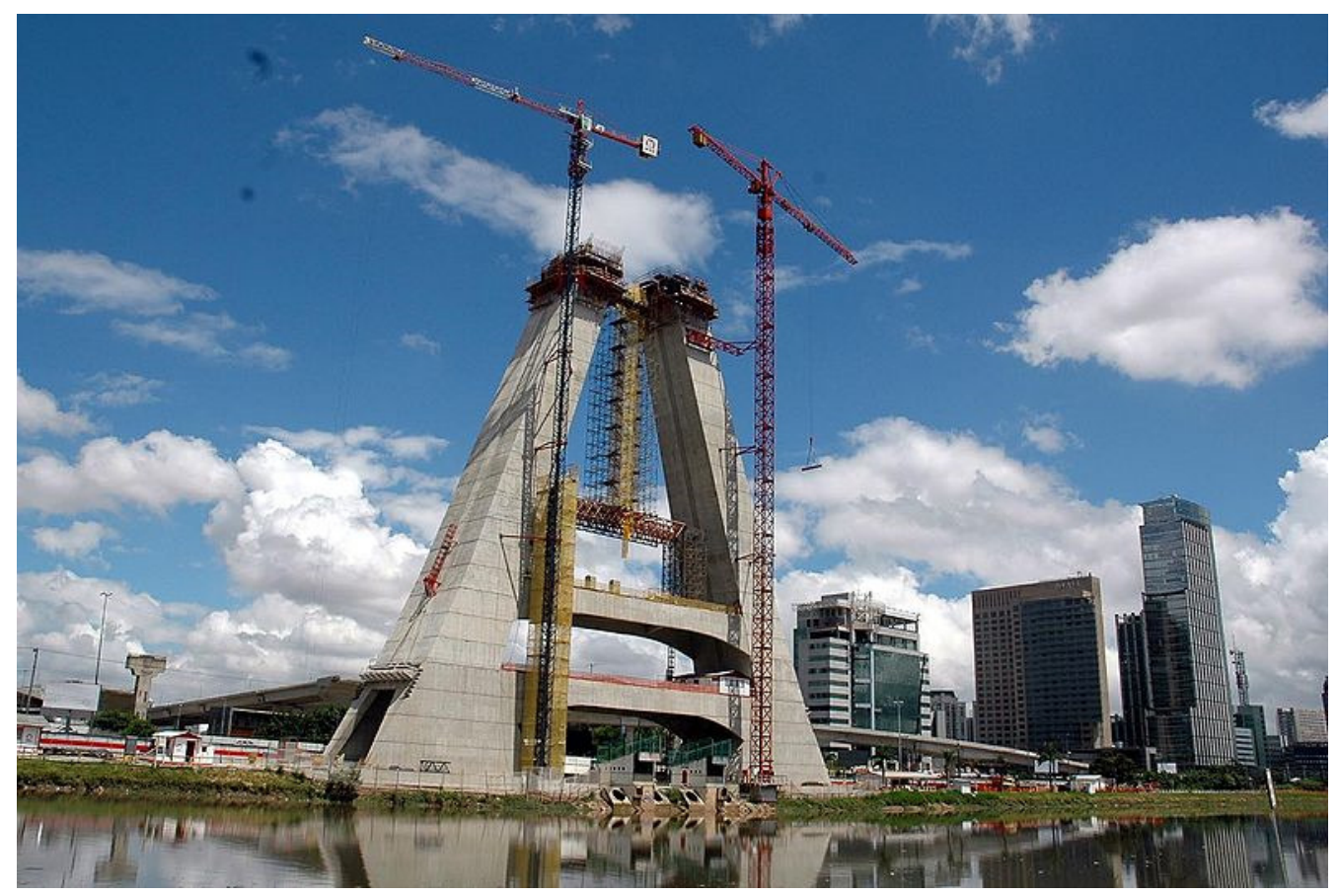

Figura 3.31 - Construção do mastro da Ponte Octavio Frias de Oliveira (http://pt.wikipedia.org/wiki/Ponte_Oct\%C3\%A1vio_Frias_de_Oliveira)

O custo total de construção da ponte foi de aproximadamente 184 milhões de reais, e mais 40 milhões de reais para a pavimentação, drenagem e novas sinalizações viárias.

Os tabuleiros da ponte foram executados pelo processo dos balanços sucessivos, partindo dos mastros até realizar o encontro com as alças de acesso. Nos pontos de ancoragem dos estais, foram inseridas células de carga capazes de monitorar as forças aplicadas a fim de ajustar as tensões de montagem, permitindo um melhor equilíbrio do tabuleiro e evitando sobrecarregar determinados estais ao longo da construção da ponte. 


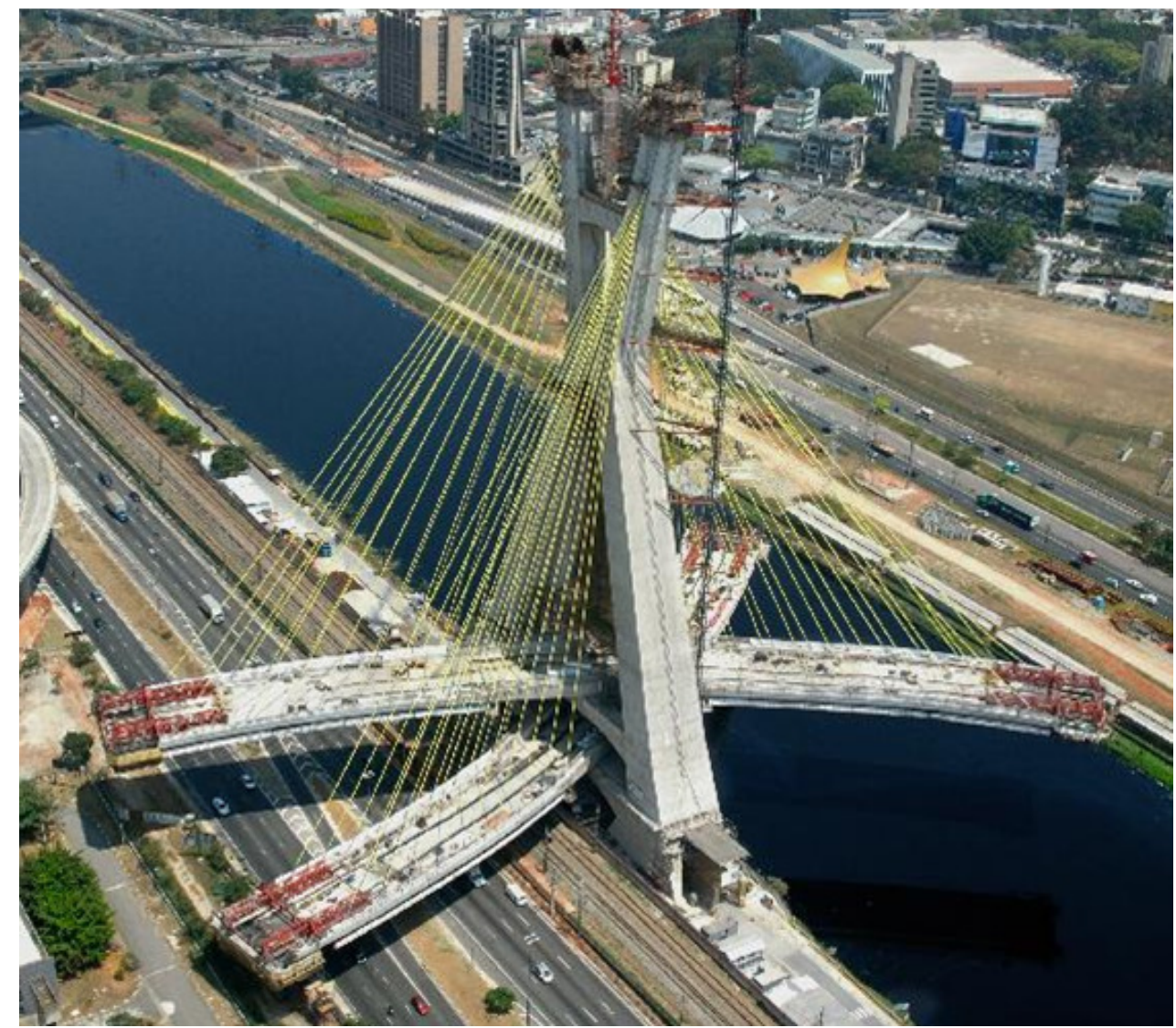

Figura 3.32 - Método das aduelas sucessivas (RIBEIRO, Catão F. - Simpósio internacional sobre pontes e grandes estruturas, 2008)

A análise dinâmica da ação do vento nesta ponte foi realizada no túnel de vento do LAC (Laboratório de Aerodinâmica das Construções) da Universidade Federal do Rio grande do Sul - UFRGS, sendo capaz de resistir a ventos de até 250 $\mathrm{km} / \mathrm{h}$.

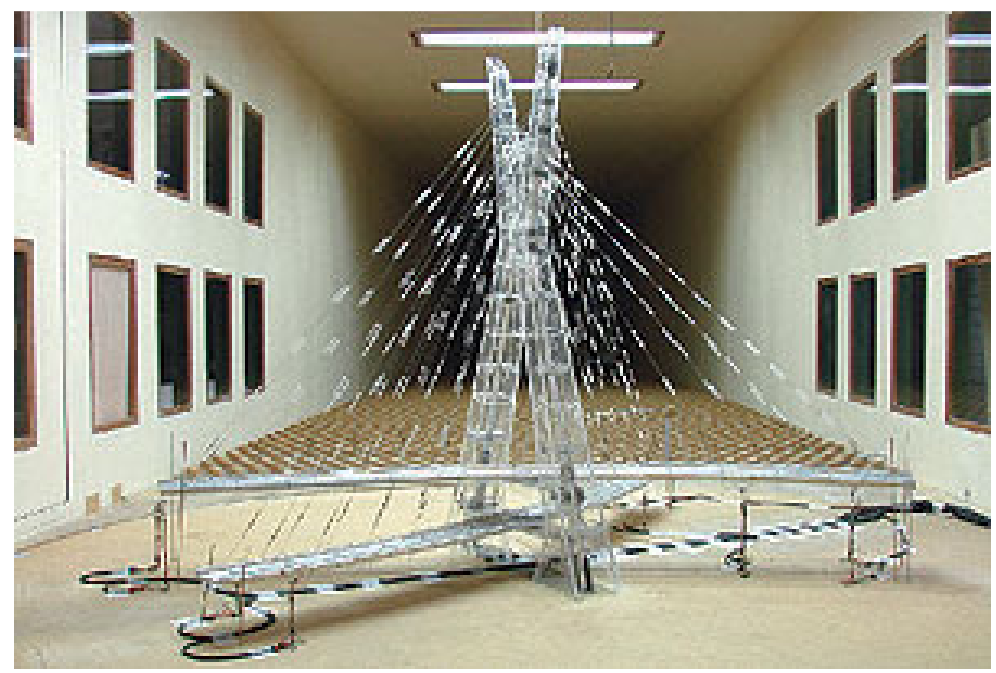

Figura 3.33 - Ensaio em Túnel de Vento

(http://www.ufrgs.br/lac/consultorias/sp_octavio_frias.htm) 
O tabuleiro de concreto protendido da ponte possui $290 \mathrm{~m}$ de extensão para cada lado do mastro e $16 \mathrm{~m}$ de largura.

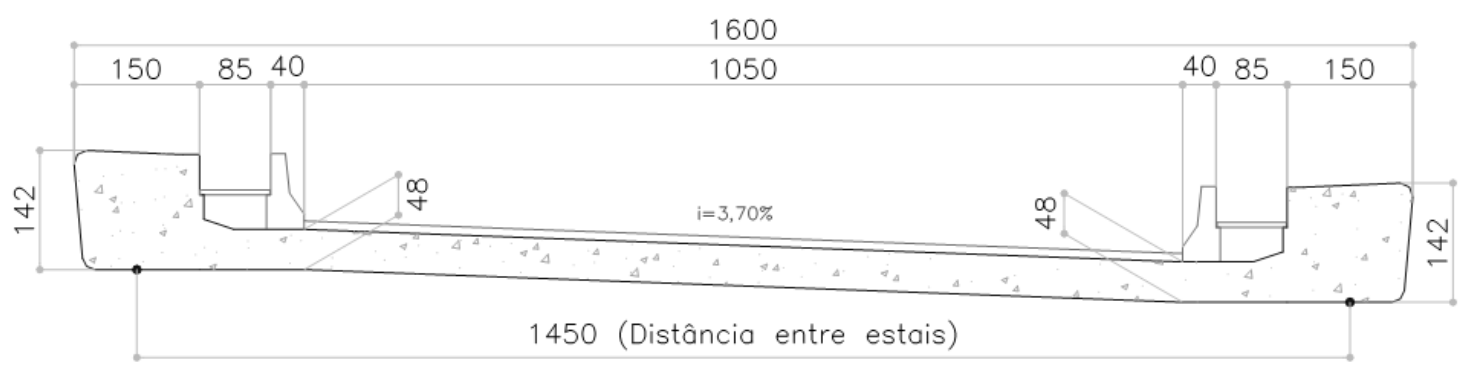

Figura 3.34 - Seção do tabuleiro (RIBEIRO, Catão F. - Simpósio internacional sobre pontes e grandes estruturas, 2008)

O mastro da ponte possui uma altura de $138 \mathrm{~m}$, que é maior que o comum para este tipo de vão, porém foi necessário para que os estais não interferissem no gabarito interno da ponte.
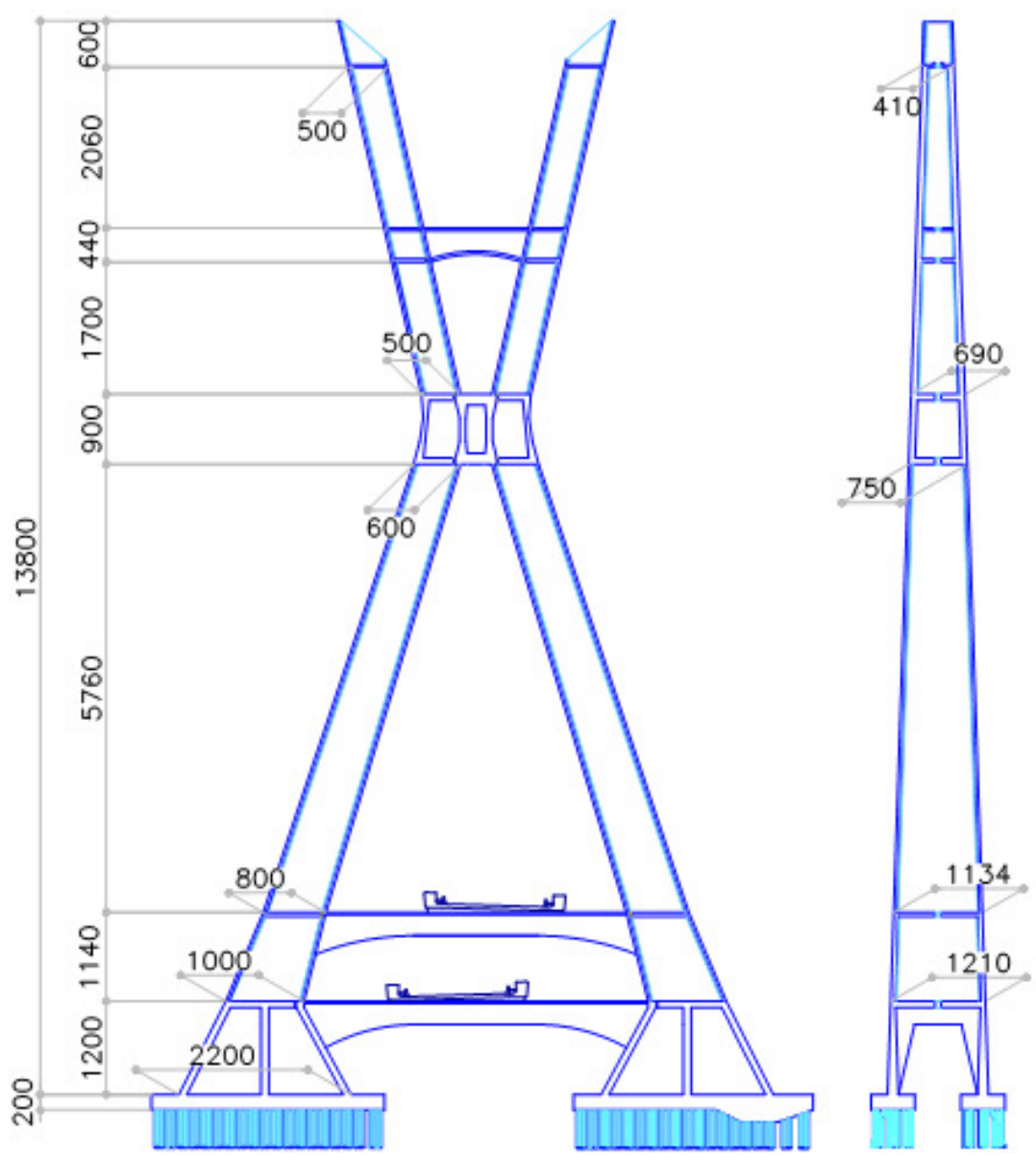

Figura 3.35 - Mastro da Ponte Octavio Frias de Oliveira (RIBEIRO, Catão F. - Simpósio internacional sobre pontes e grandes estruturas, 2008) 
Para dar suporte ao tabuleiro, foram utilizados 18 pares de estais em cada um dos 4 vãos da ponte, totalizando 144 estais e um peso de 462 toneladas de aço.

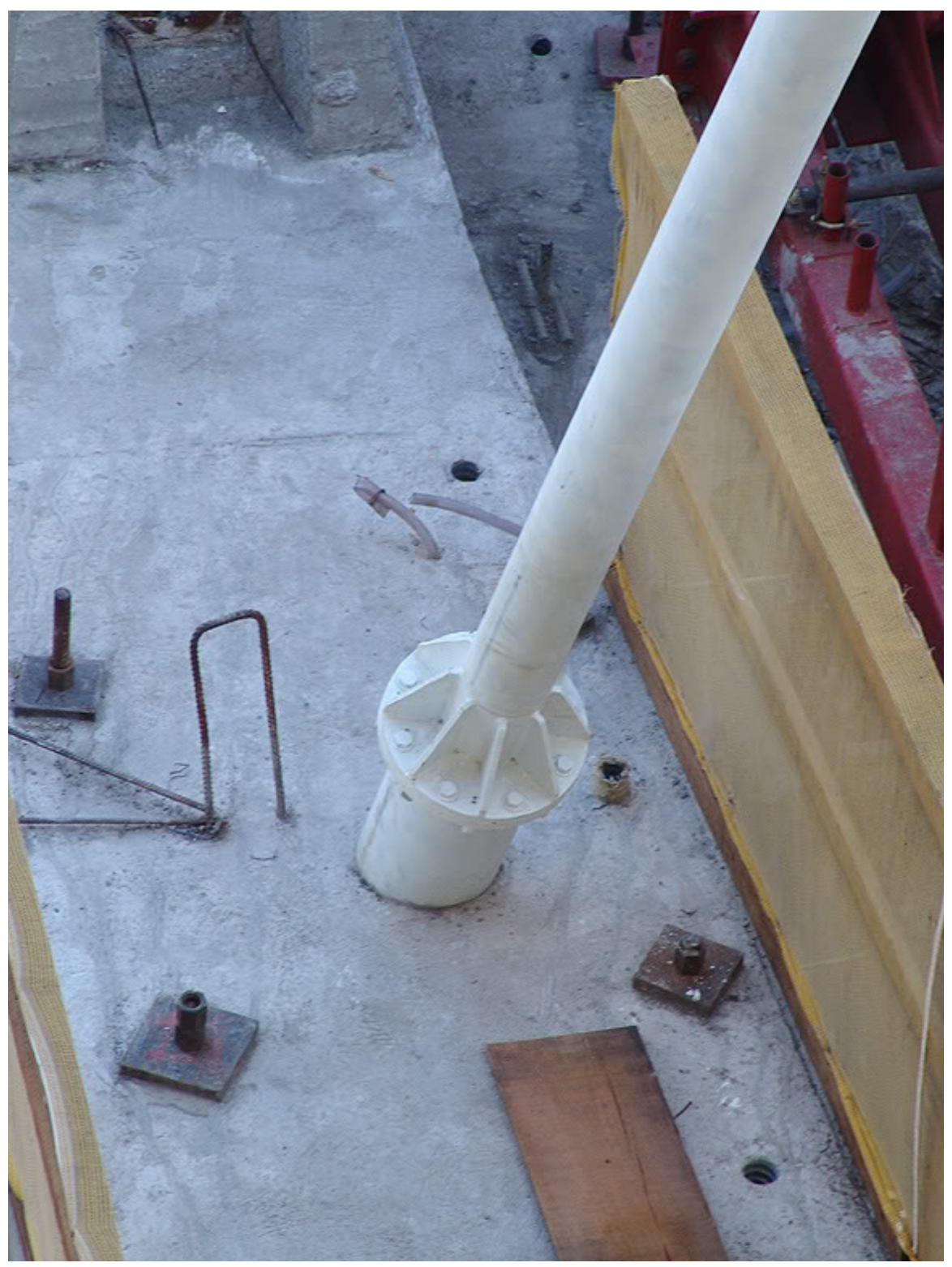

Figura 3.36 - Chegada do estai no tabuleiro (http://www.skyscrapercity.com/showthread.php?t=445341\&page=13)

O arranjo dos cabos é espacial, devido à curvatura do tabuleiro, o que gerou um cruzamento de estais próximo à ancoragem dos estais no mastro. Estes são protegidos com um tubo amarelo de polietileno de elevada resistência mecânica, resistente à ação de raios ultravioleta, com a função de proteger o aço contra corrosão. 


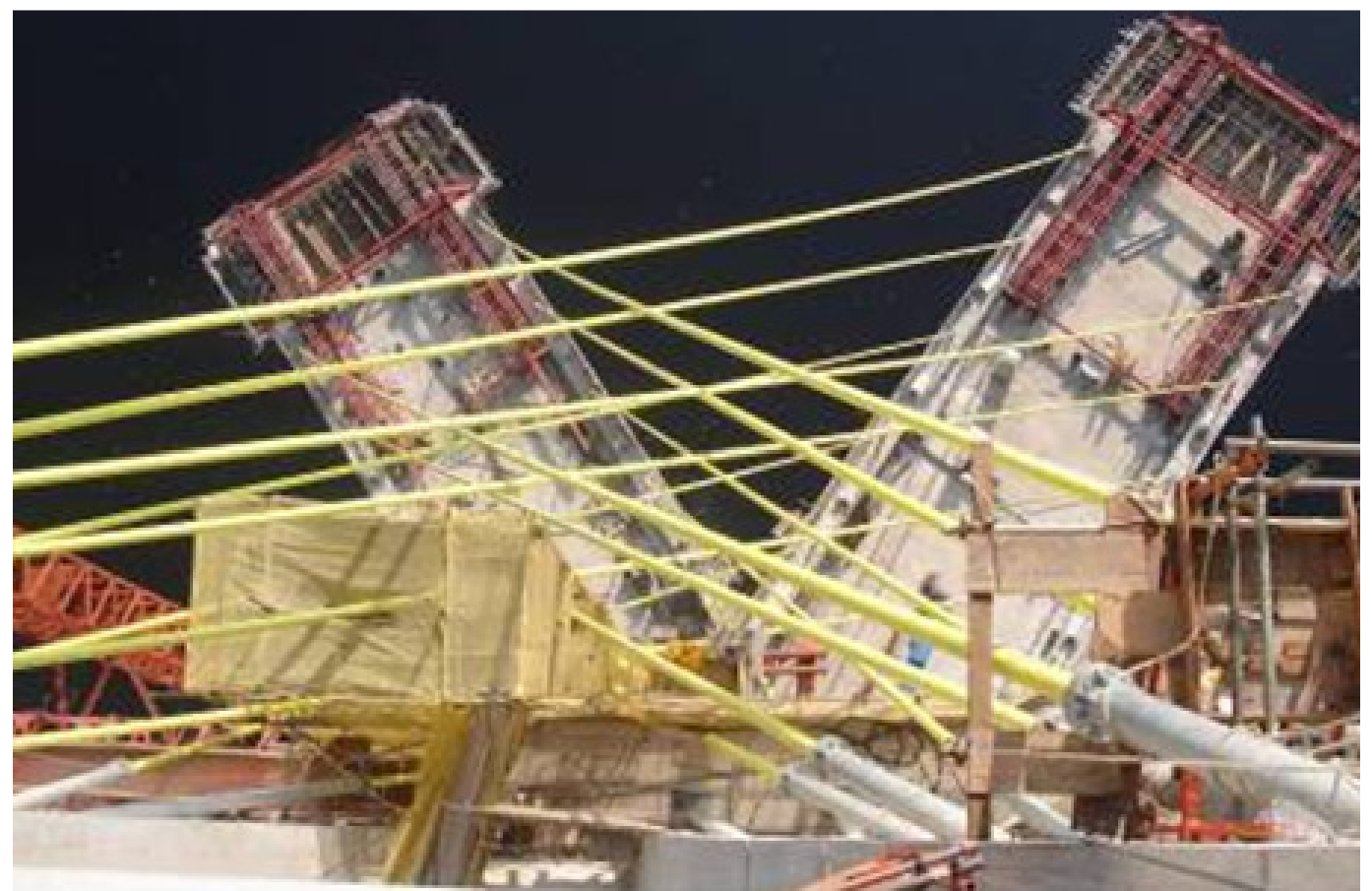

Figura 3.37 - Cruzamento dos Estais (RIBEIRO, Catão F. - Simpósio internacional sobre pontes e grandes estruturas, 2008)

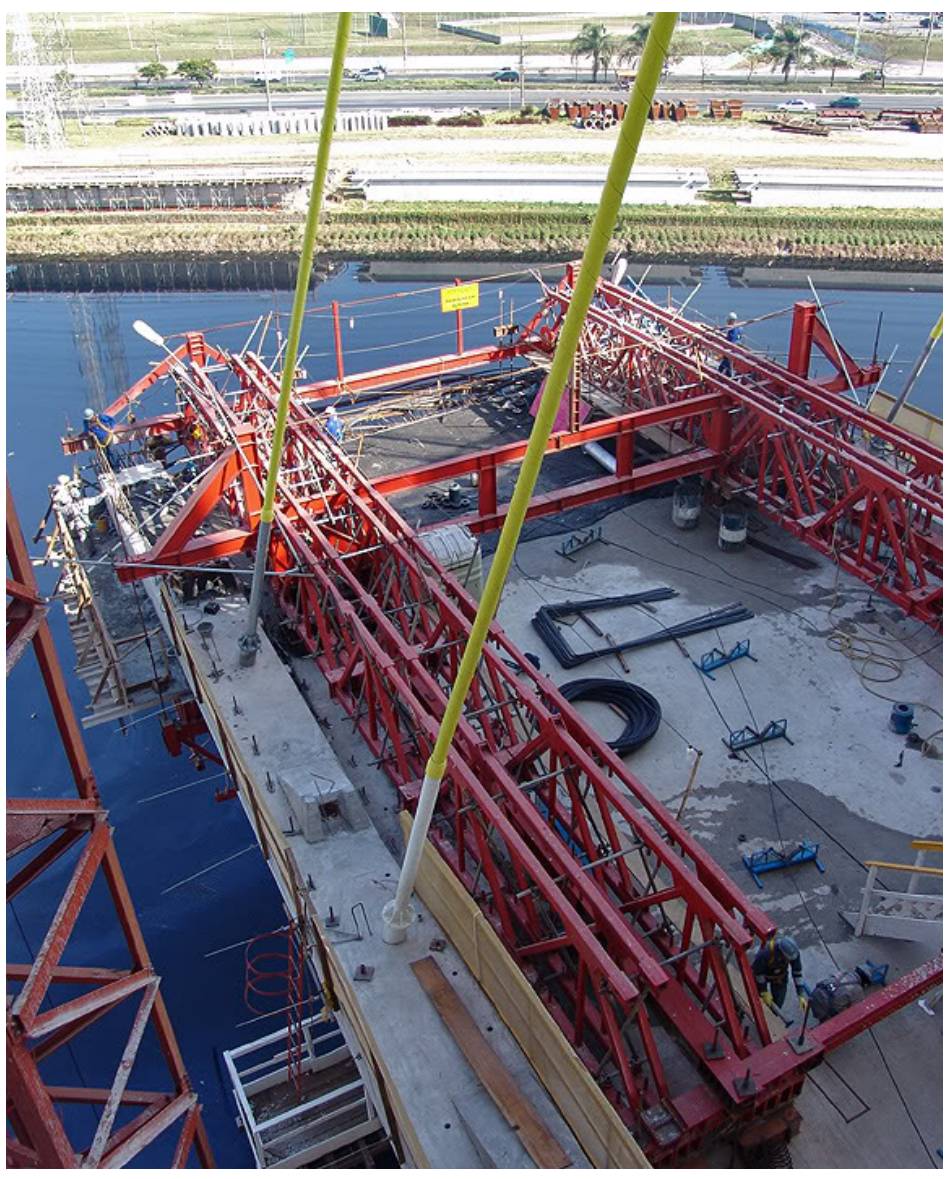

Figura 3.38 - Execução do tabuleiro através do método dos balanços sucessivos (http://www.skyscrapercity.com/showthread.php?t=445341\&page=13) 


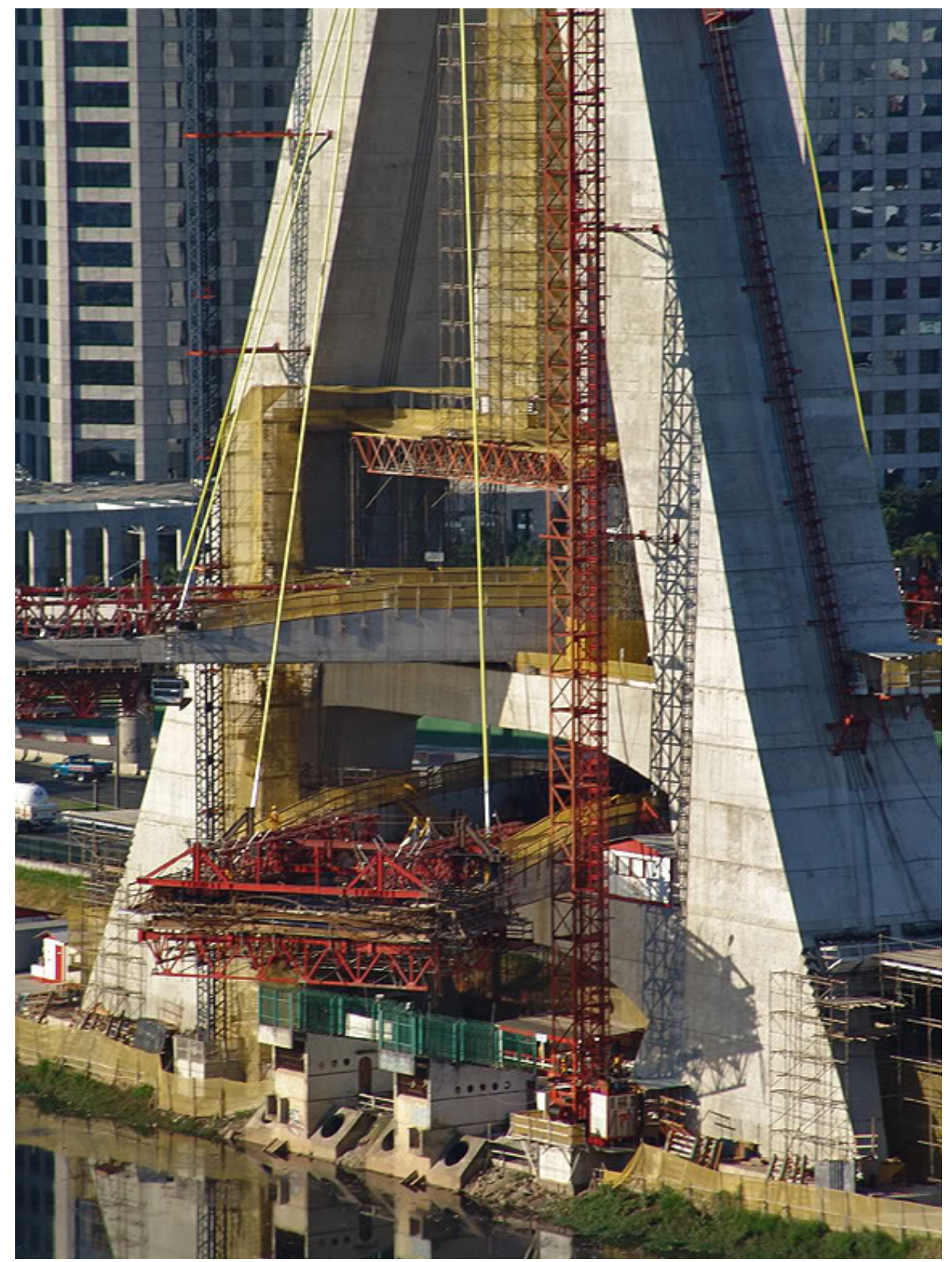

Figura 3.39 - Execução dos tabuleiros

(http://www.skyscrapercity.com/showthread.php?t=445341\&page=13) 


\subsection{PONTE ESTAIADA SOBRE O RIO PARANÁ}

A ponte estaiada sobre o Rio Paraná fica localizada em Paulicéia, na divisa de São Paulo com Mato Grosso. Está ponte foi construída com o intuito de facilitar a travessia do Rio Paraná, que nesse trecho era feita por meio de embarcações.

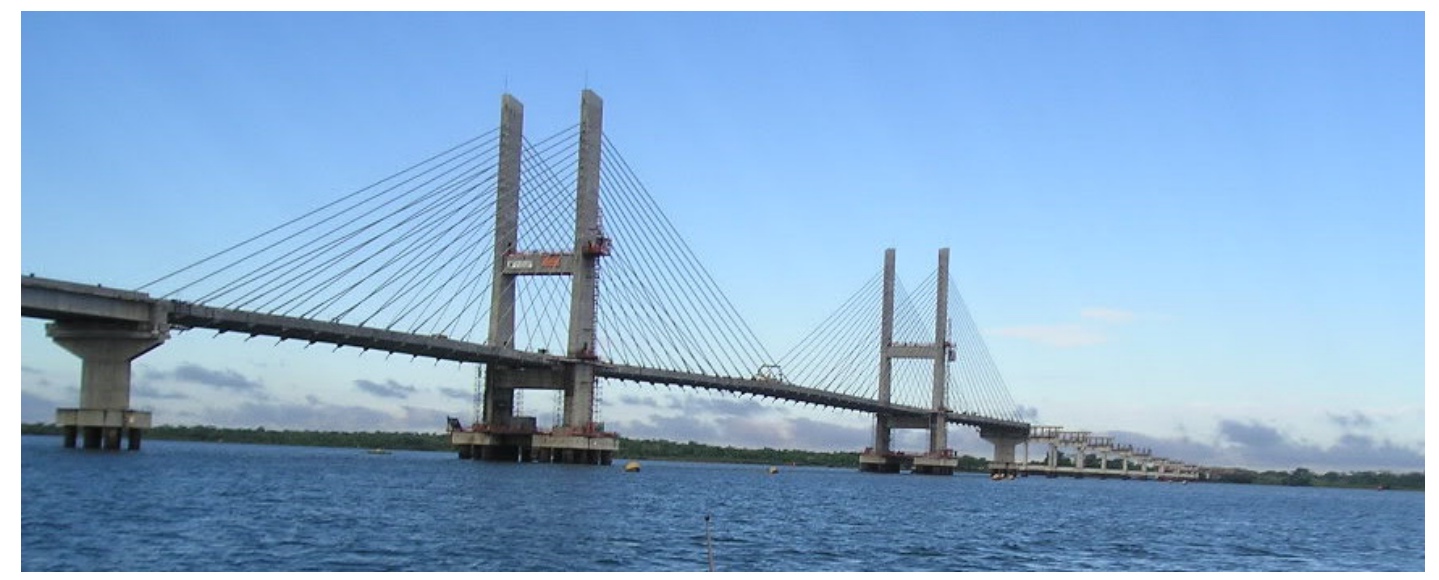

Figura 3.40 - Ponte sobre o Rio Paraná (http://www.skyscrapercity.com/showthread.php?t=750762)

A construção da ponte foi executada pela Construtora Camargo Correa, e o projeto estrutural foi desenvolvido pela Enescil.

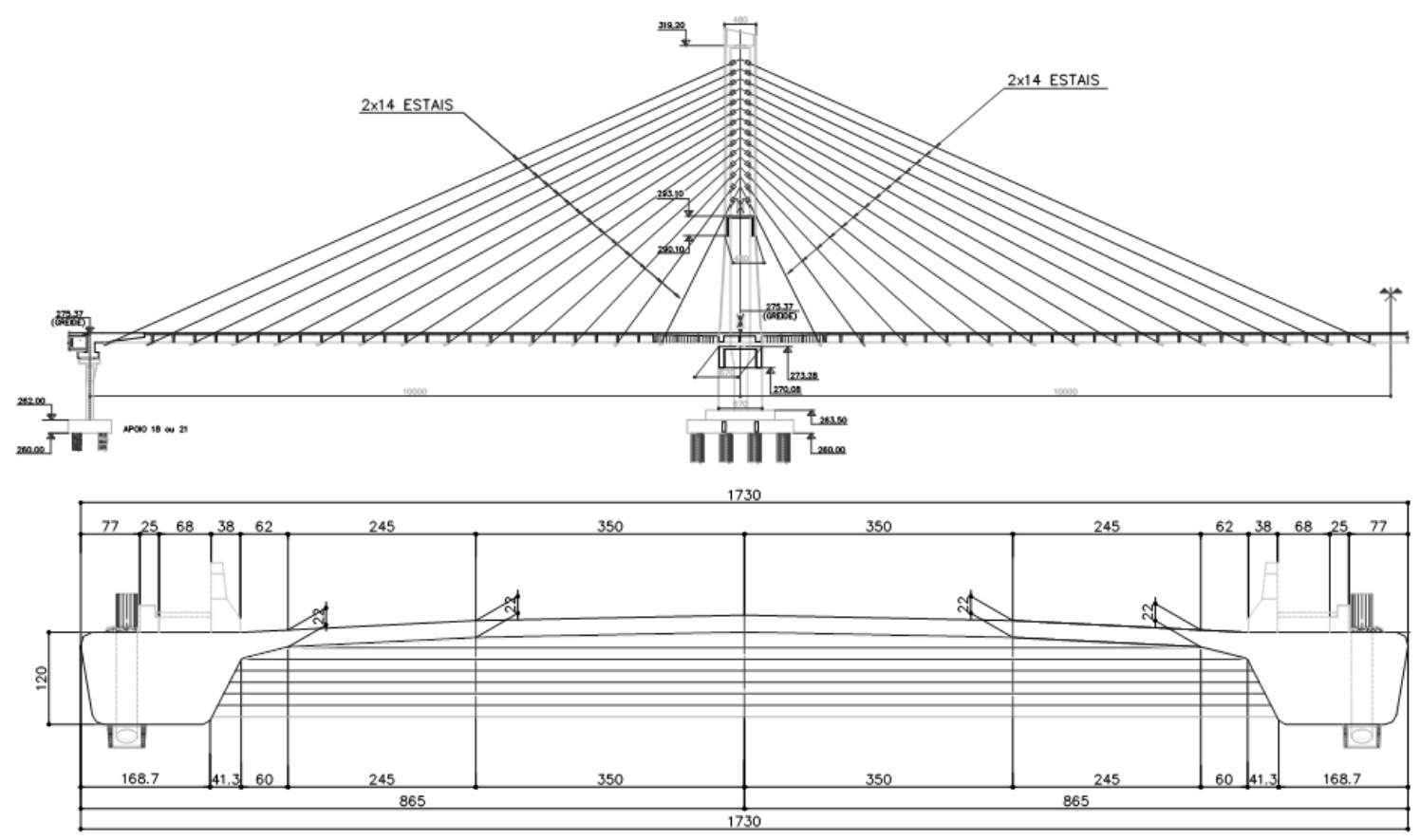

Figura 3.41 - Geometria da Ponte sobre o Rio Paraná (RIBEIRO, Catão F. - Simpósio internacional sobre pontes e grandes estruturas, 2008) 
A ponte possui $1700 \mathrm{~m}$ de extensão, com um vão central estaiado de $200 \mathrm{~m}$ e dois trechos laterais estaiados de $100 \mathrm{~m}$ cada.

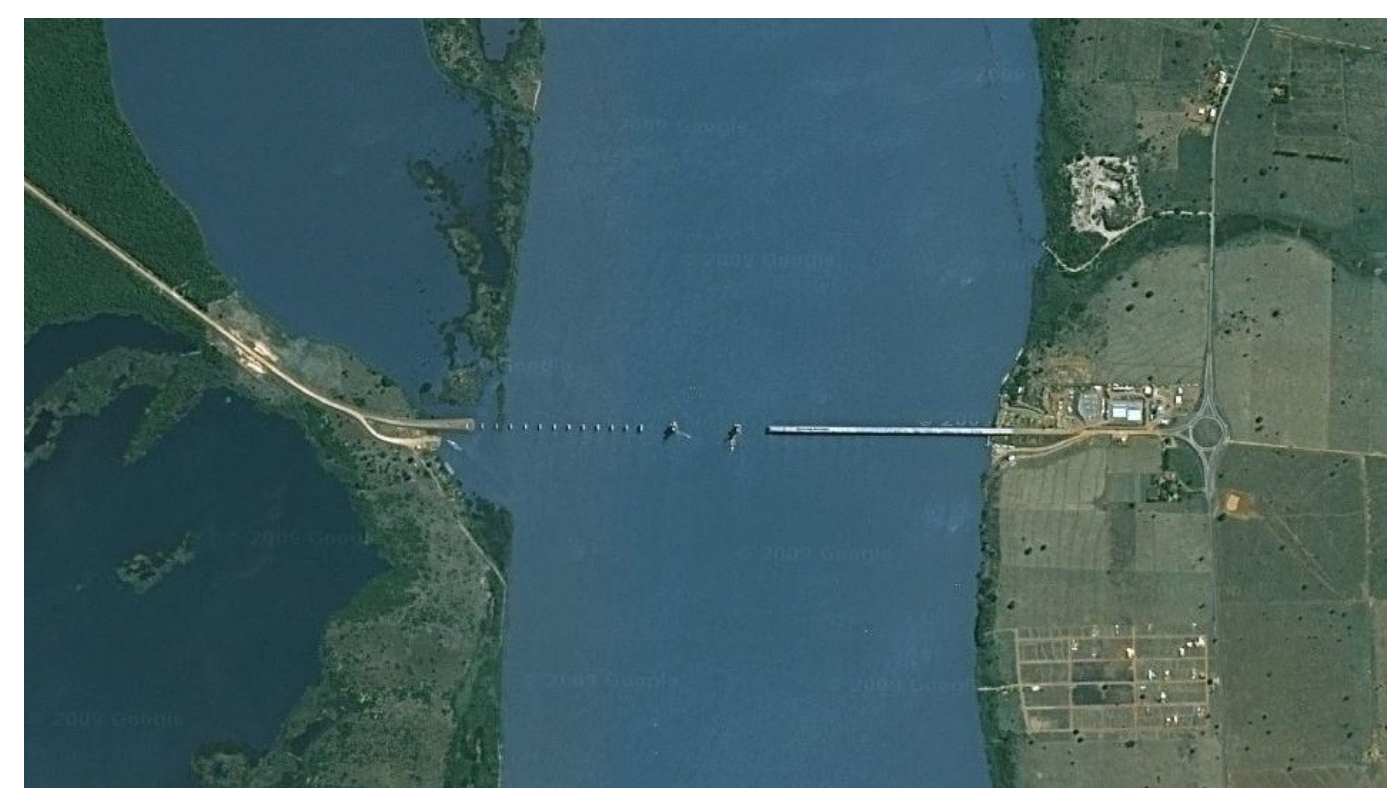

Figura 3.42 - Vista de satélite da construção da Ponte sobre o Rio Paraná (Google Maps)

O tabuleiro de concreto protendido de $18 \mathrm{~m}$ de largura é suportado por dois planos verticais de cabos, com geometria em semi harpa. Sua execução foi realizada através do método dos balanços sucessivos.

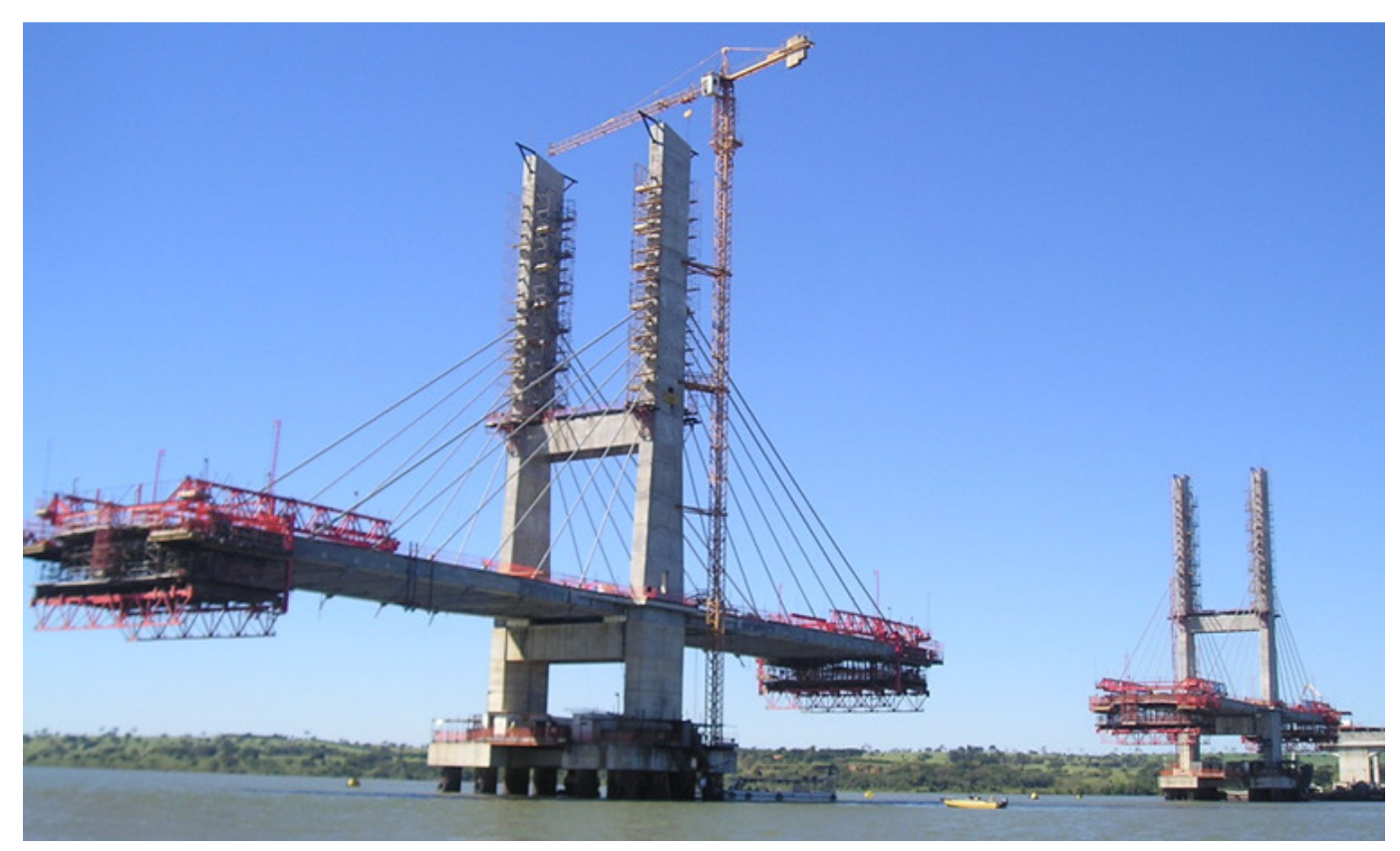

Figura 3.43 - Execução do trecho estaiado (http://www.skyscrapercity.com/showthread.php?t=750762) 


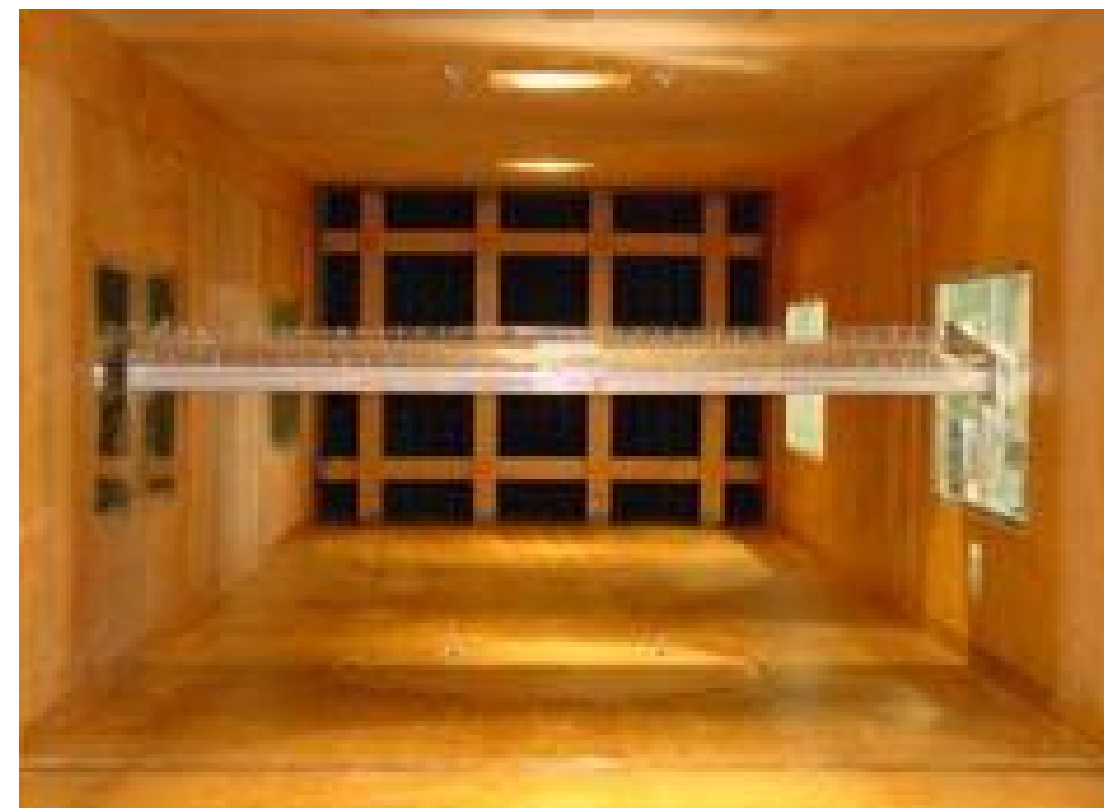

Figura 3.44 - Modelo do tabuleiro ensaiado em túnel de vento no Laboratório de Aerodinâmica das Construções da UFRGS (http://www.ufrgs.br/lac/consultorias/sp_pauliceia.htm) 


\subsection{PONTE ESTAIADA JOÃO ISIDORO FRANÇA}

A Ponte João Isidoro França foi construída na cidade Teresina, no Piauí, em comemoração aos 150 anos da cidade. Conhecida também como ponte do sesquicentenário, a ponte teve sua construção iniciada em 2002 e foi inaugurada no dia 30 de março de 2010.

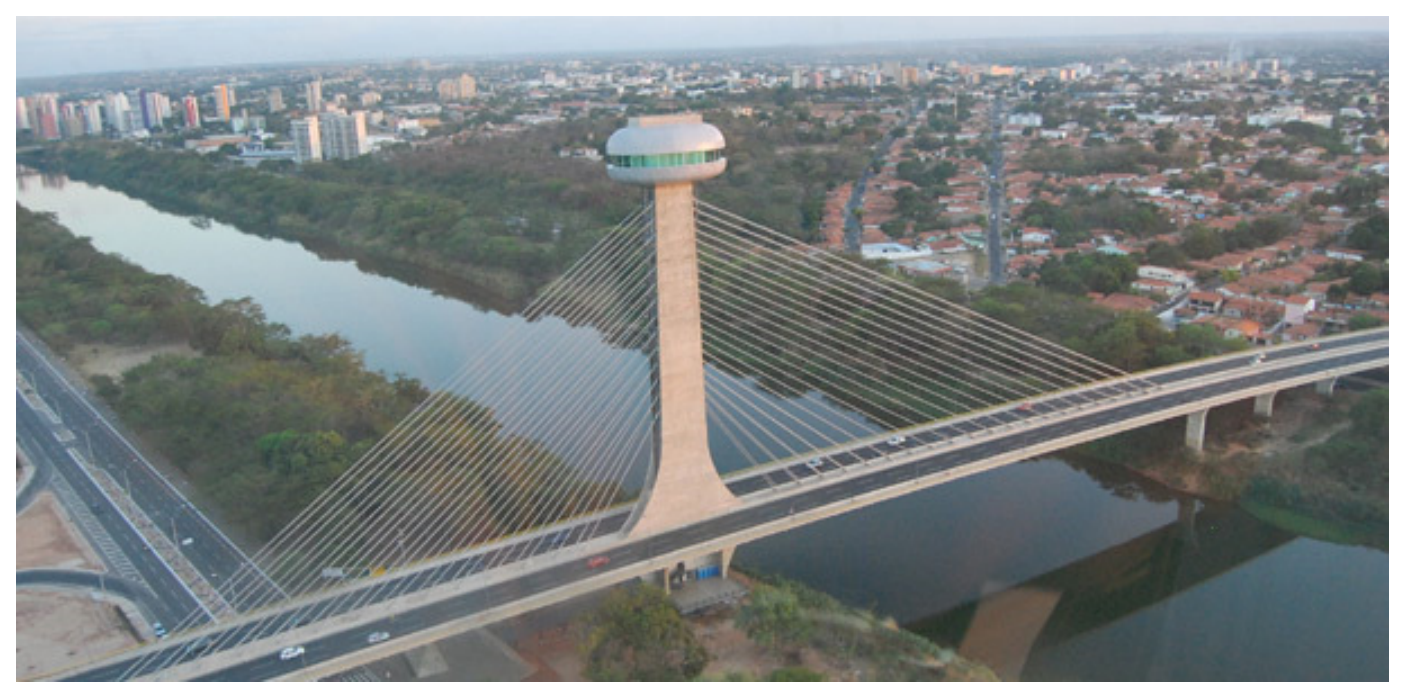

Figura 3.45 - Ponte Estaiada João Isidoro França (http://www.skyscrapercity.com/showthread.php?t=784972)

Com uma extensão total de 363 metros, o tabuleiro de concreto protendido possui de cada lado do mastro três faixas de rodagem de $3,1 \mathrm{~m}$ de e um passeio de 2,15 m de largura. Este tabuleiro possui uma geometria diferente do comumente executado nas pontes deste tipo, uma vez que este não é fechado lateralmente. (Figura 3.46).

Os estais estão dispostos em um único plano central de estaiamento, na geometria de semi harpa. O mastro de concreto possui $98 \mathrm{~m}$ de altura sobre o solo, abrigando no seu topo um mirante em estrutura metálica, que pode ser acessado através de elevadores panorâmicos e escadas de emergência.

A execução da ponte teve como finalidade a interligação da Avenida Dom Severino e a Alameda Parnaíba, trazendo melhorias ao trânsito da região. O custo para execução desta ponte, por onde passam 45 mil veículos por dia, foi de 74 milhões de reais. 


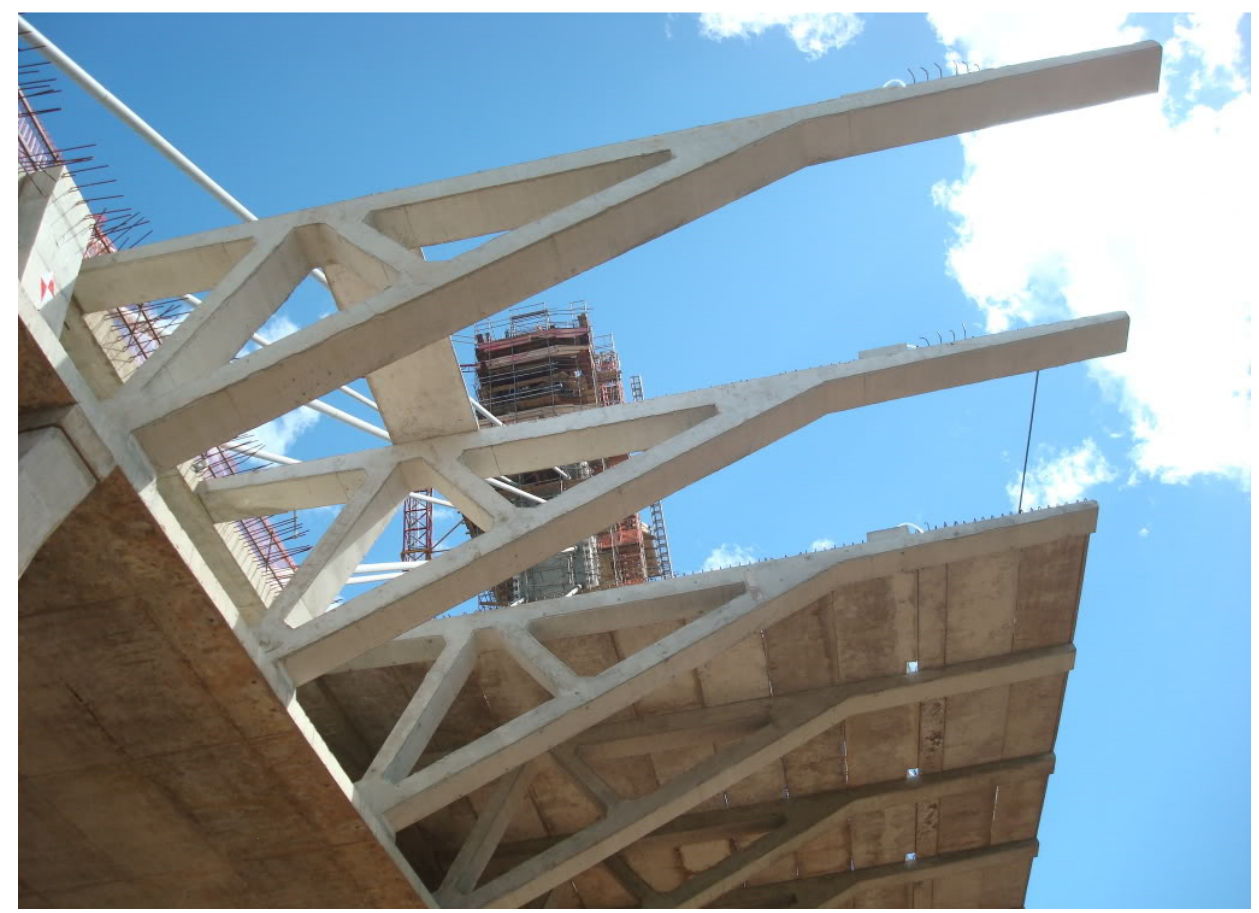

Figura 3.46 - Execução do tabuleiro da Ponte João Isidoro França (http://www.skyscrapercity.com/showthread.php?t=784972)

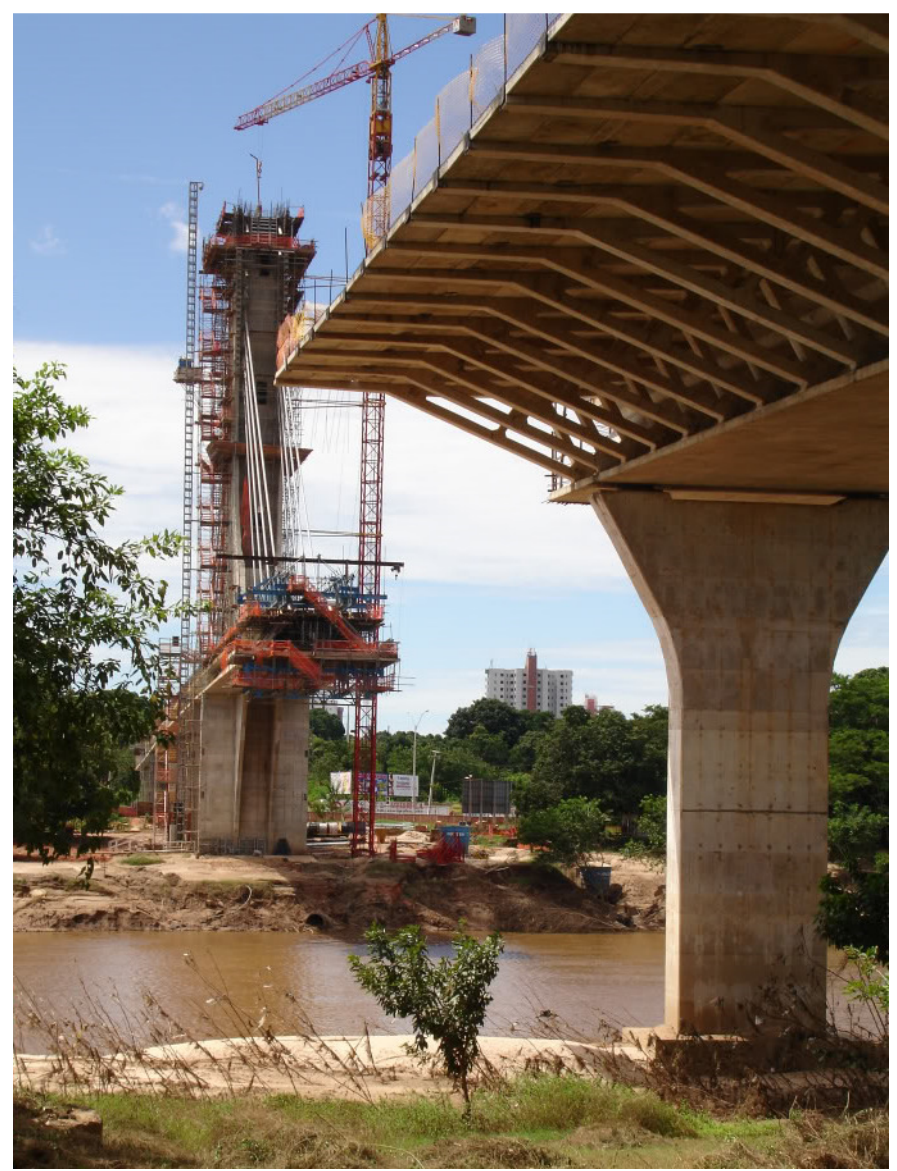

Figura 3.47 - Execução do tabuleiro estaiado (http://www.skyscrapercity.com/showthread.php?t=784972) 


\subsection{PONTE SOBRE O RIO NEGRO}

A ponte estaiada sobre o Rio Negro é um projeto do Governo do Estado do Amazonas, e faz parte de um conjunto de investimentos para a região metropolitana de Manaus.

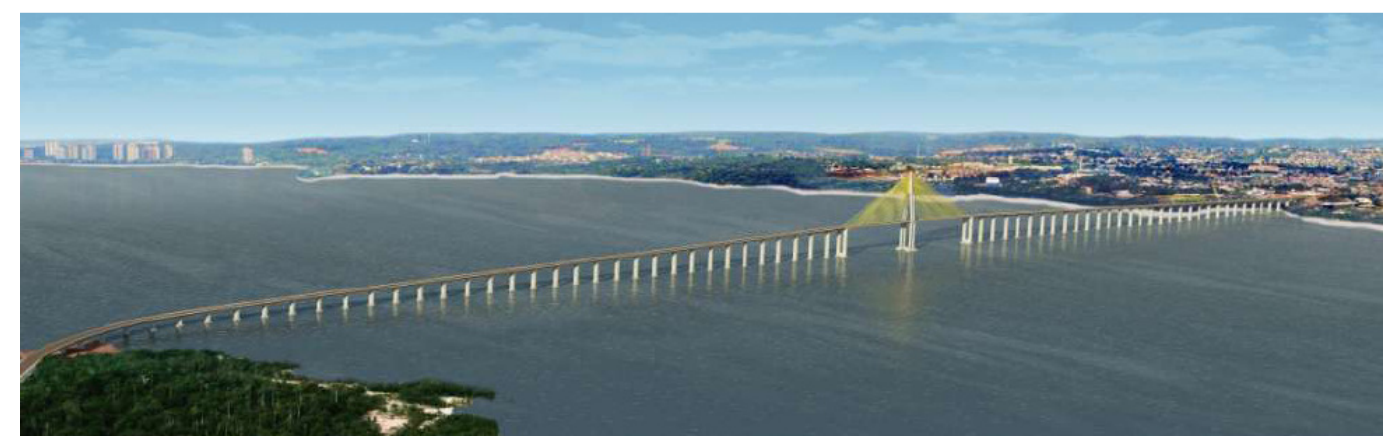

Figura 3.48 - Perspectiva artística da Ponte sobre o Rio Negro (http://www.ibracon.org.br/eventos/52cbc/HENRIQUE_DOMINGUES.pdf)

A ponte possui um comprimento total de $3595 \mathrm{~m}$, com 73 vãos utilizando vigas pré-moldadas de concreto e 2 vãos estaiados de $200 \mathrm{~m}$ cada. O tabuleiro de concreto protendido possui 22,6 m de largura no trecho estaiado e 20,7 m de largura no trecho convencional.

O mastro de concreto possui $103,3 \mathrm{~m}$ acima do tabuleiro, que por sua vez encontra-se $55 \mathrm{~m}$ acima do nível d'água normal.

Para o trecho central estaiado, foram utilizados 104 estais dispostos em dois planos inclinados de estaiamento.

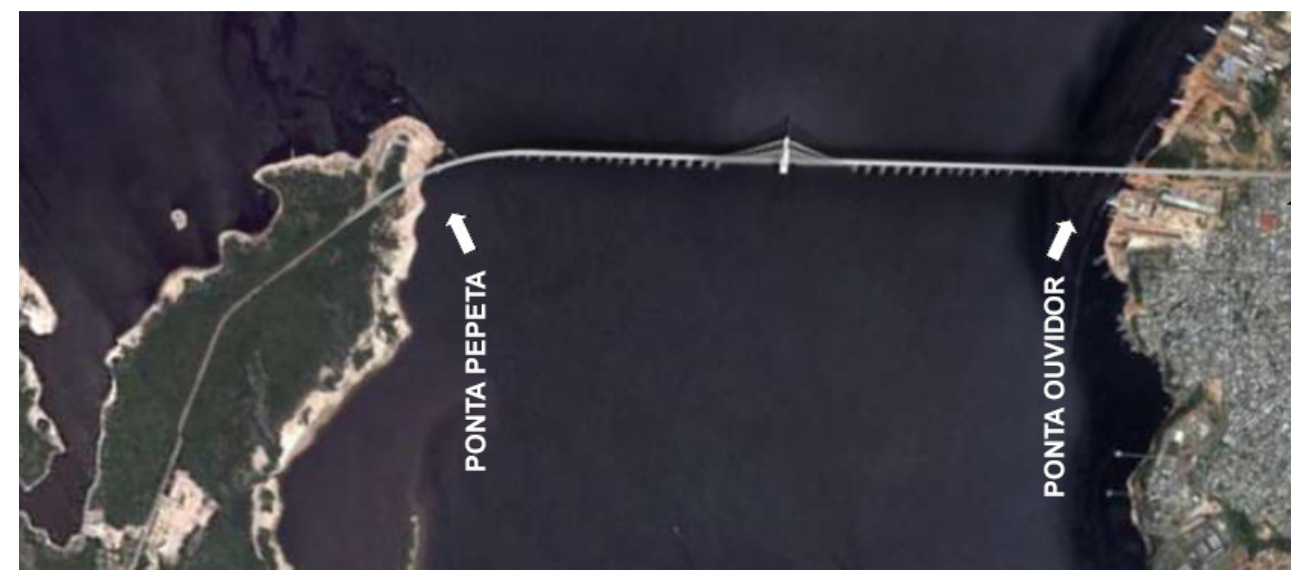

Figura 3.49 - Ilustração da ponte sobre a foto de satélite (http://www.ibracon.org.br/eventos/52cbc/HENRIQUE_DOMINGUES.pdf) 


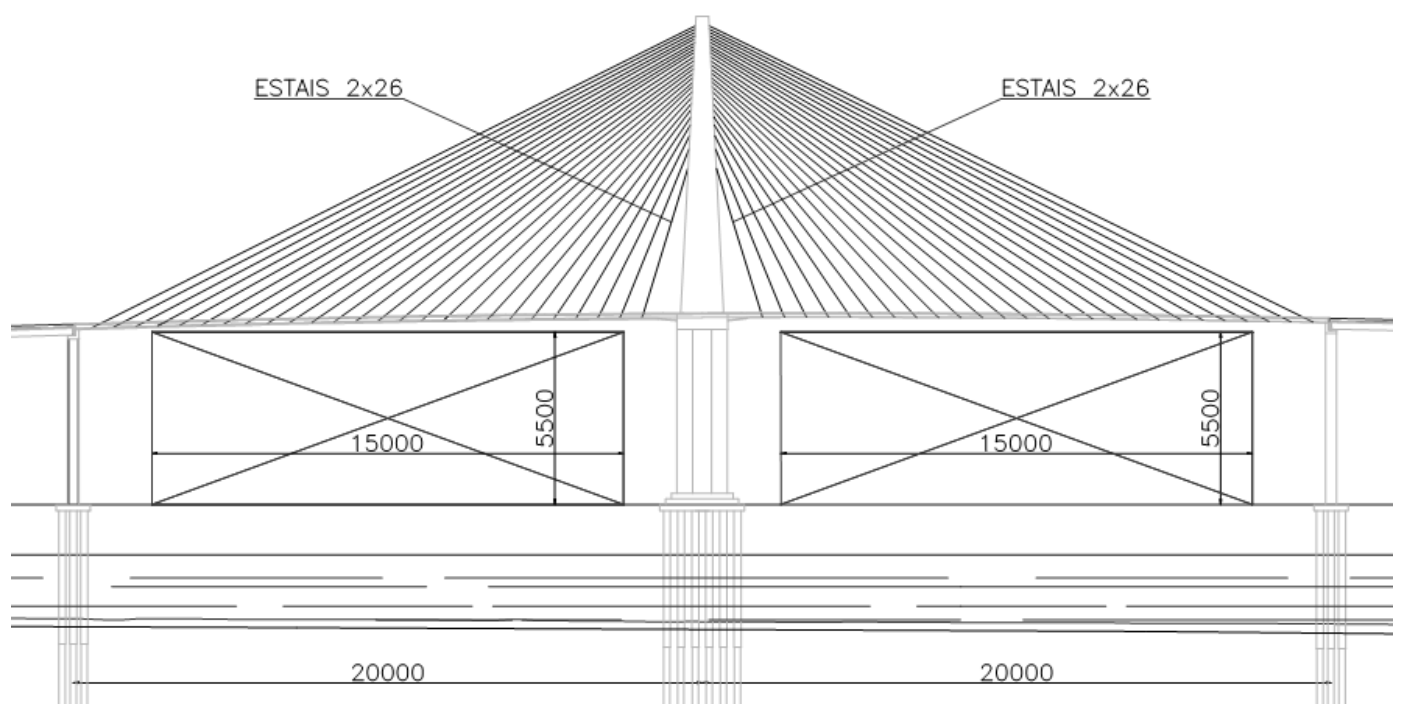

Figura 3.50 - Geometria do trecho estaiado (http://www.ibracon.org.br/eventos/52cbc/HENRIQUE_DOMINGUES.pdf)

Uma das premissas para a execução da ponte é que durante todo o ano 0 gabarito mínimo para passagem de qualquer embarcação seja mantido. Para isso, o trecho central estaiado foi projetado com dois vãos livres de 150 de largura e $55 \mathrm{~m}$ de altura.

A execução do tabuleiro no trecho convencional foi feita utilizando-se vigas pré-moldadas e pré-lajes. Já para o trecho estaiado foi utilizado o método das aduelas sucessivas, que são de concreto protendido, executadas no canteiro e içadas até a ponte.

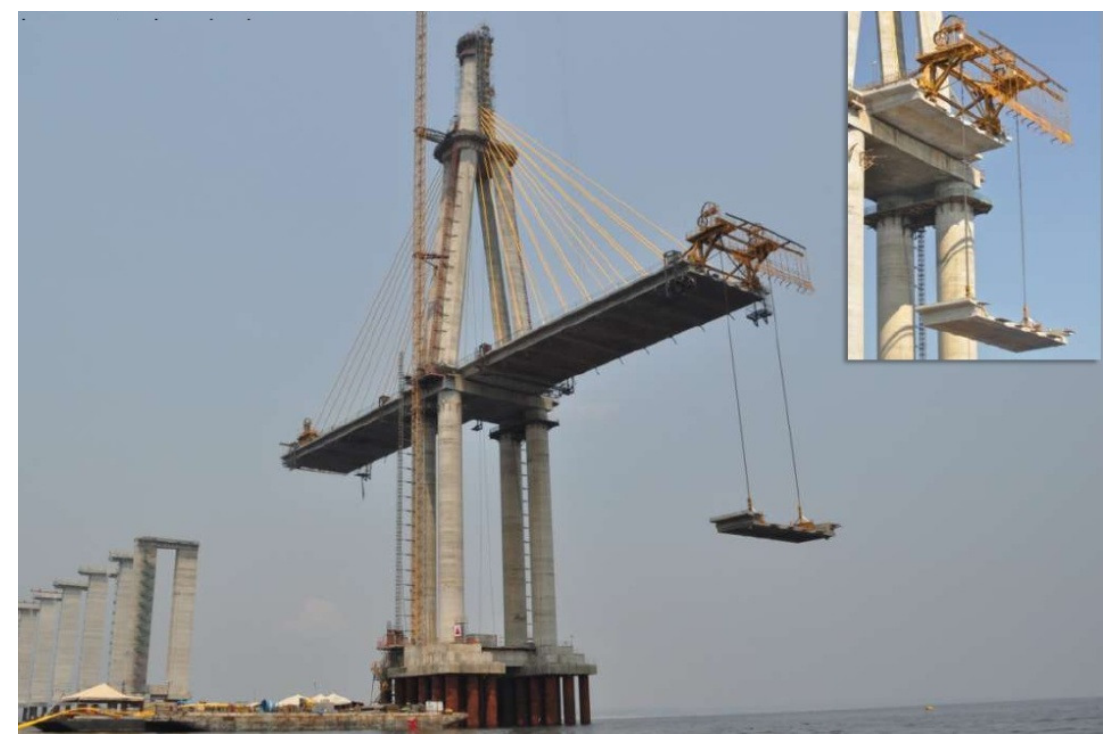

Figura 3.51 - lçamento dos elementos pré-moldados (http://www.ibracon.org.br/eventos/52cbc/HENRIQUE_DOMINGUES.pdf) 


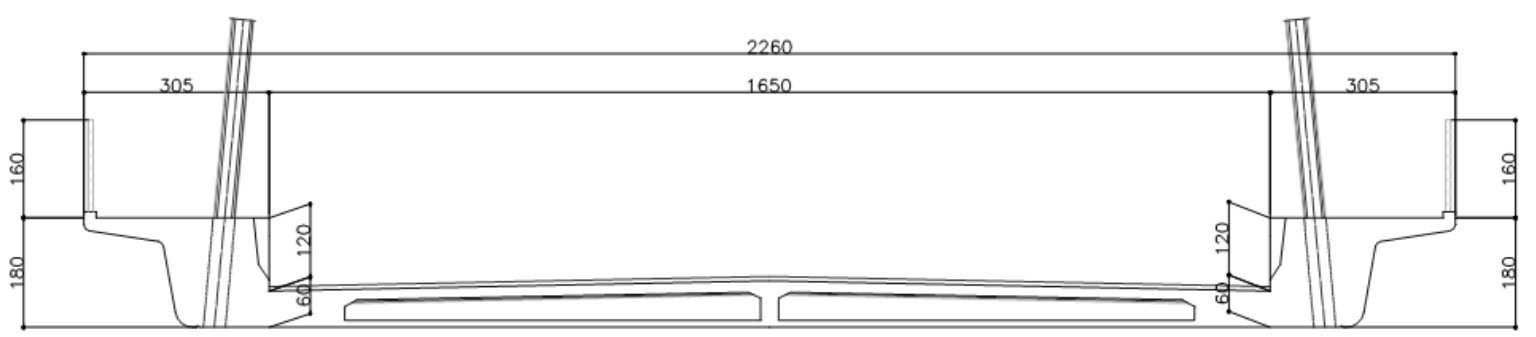

Figura 3.52 - Geometria do tabuleiro no trecho estaiado (http://www.ibracon.org.br/eventos/52cbc/HENRIQUE_DOMINGUES.pdf)

O consórcio responsável pela execução da ponte é formado pela Construtora Camargo Corrêa e a Construbase. O cronograma para entrega da ponte era para o final de 2010, porém, devido a problemas climáticos e de falta de insumos, a conclusão da ponte ficará para o ano de 2011.

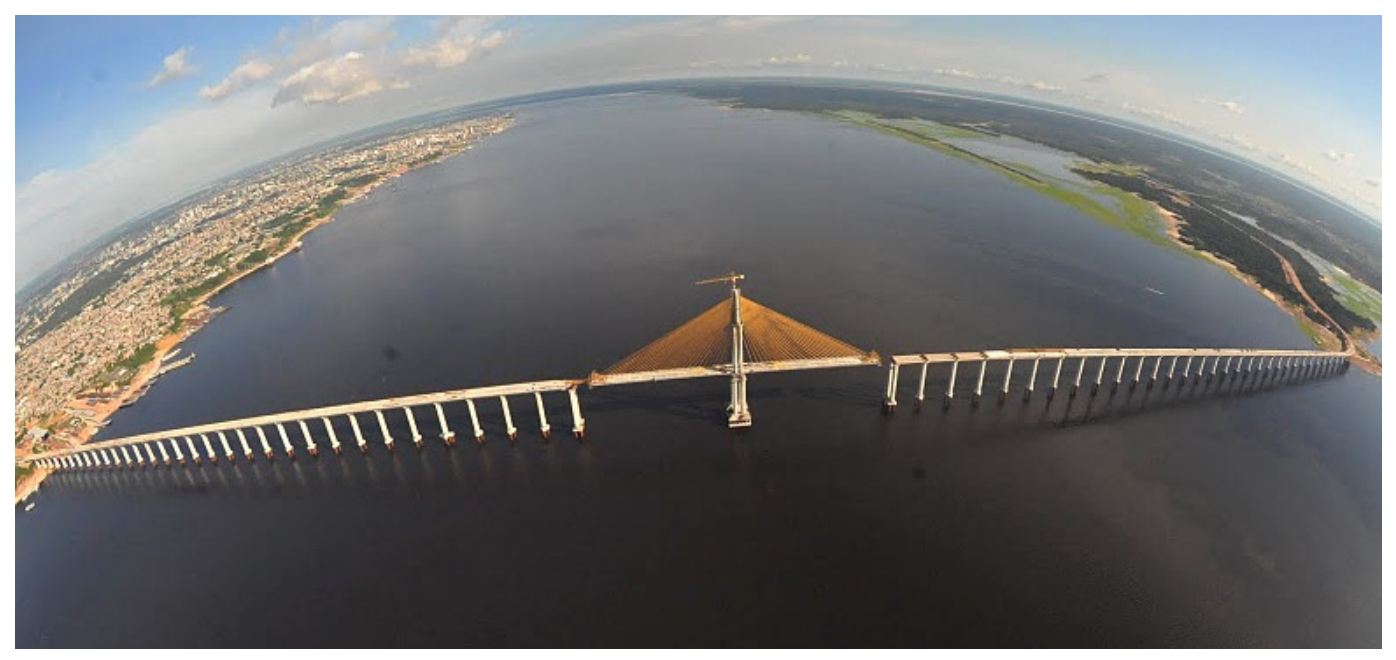

Figura 3.53 - Situação da ponte em janeiro de 2011 (http://www.skyscrapercity.com/showthread.php?t=558724\&page=52) 


\subsection{PASSARELA JOAQUIM FALCÃO MACEDO}

No Brasil existem diversas passarelas estaiadas, porém a Passarela Joaquim Falcão Macedo merece destaque pela sua inovação e estética. Localizada em Rio Branco, no Acre, a passarela inaugurada em outubro de 2006, recebe um público de 20 mil pessoas por dia.

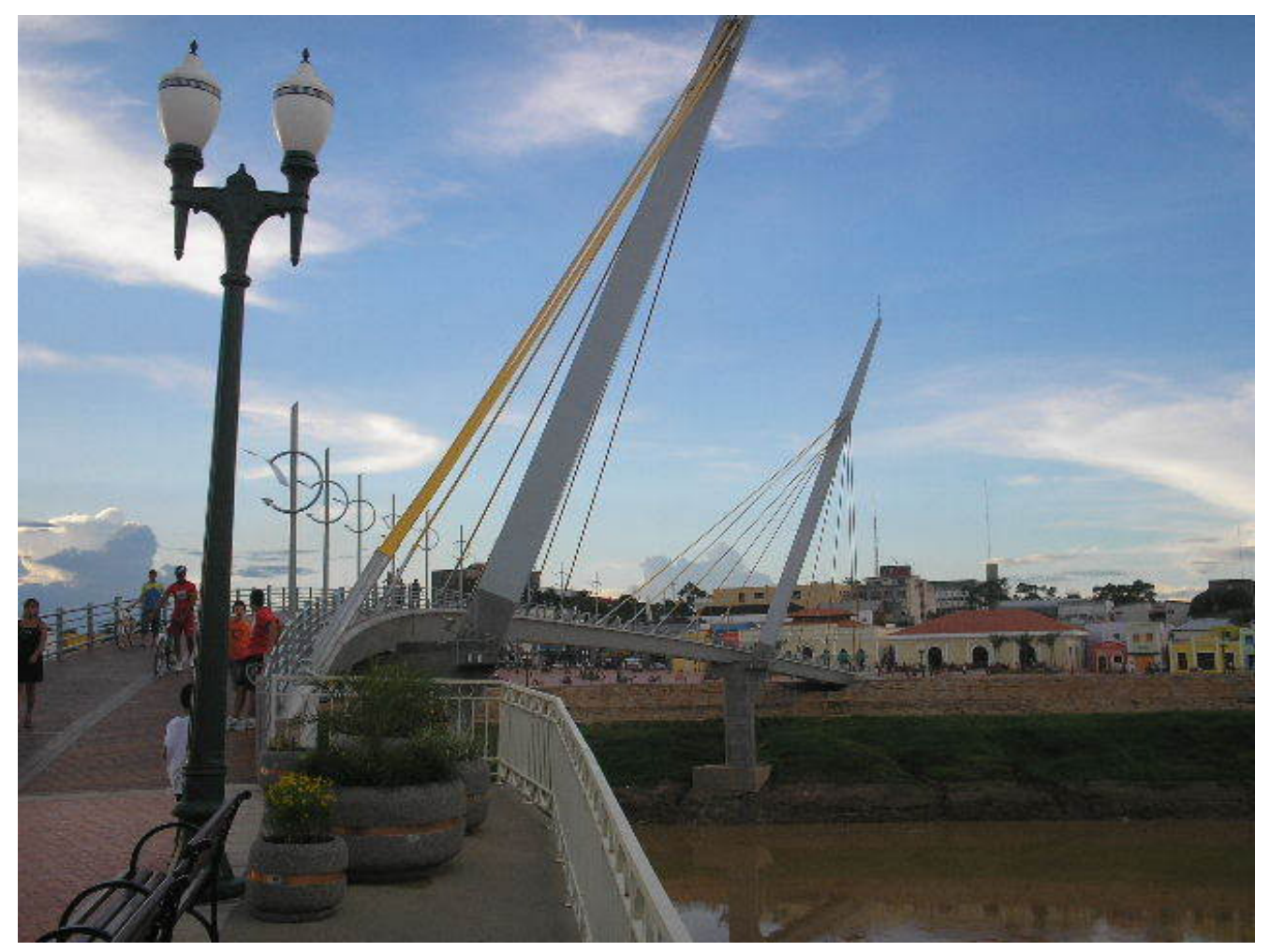

Figura 3.54 - Passarela Joaquim Falcão Macedo (http://www.skyscrapercity.com/showthread.php?t=449291)

A passarela possui $200 \mathrm{~m}$ de extensão, com um vão central de $110 \mathrm{~m}$ e dois vãos laterais de $45 \mathrm{~m}$ cada. $O$ tabuleiro com seção caixão possui largura constante de $5,5 \mathrm{~m}$ e é suportado por dois mastros metálicos inclinados para o centro da curvatura do tabuleiro

Esta obra foi executada pela Construtora Cidade Ltda. O projeto estrutural foi elaborado pela Outec Engenharia Ltda.. Nesta obra foram utilizados $830 \mathrm{~m}^{3}$ de concreto e 460 toneladas de aço. 


\subsection{DEMAIS PONTES ESTAIADAS BRASILEIRAS}

No Brasil existem diversas pontes estaiadas que não foram citadas nos itens anteriores, uma vez que não é a finalidade expor todas, mas sim apresentar um contexto geral.

A seguir serão ilustradas de maneira mais superficial algumas pontes estaiadas existentes no território nacional, e algumas que estão em construção ou projeto:

\section{Ponte Irineu Bornhausen:}

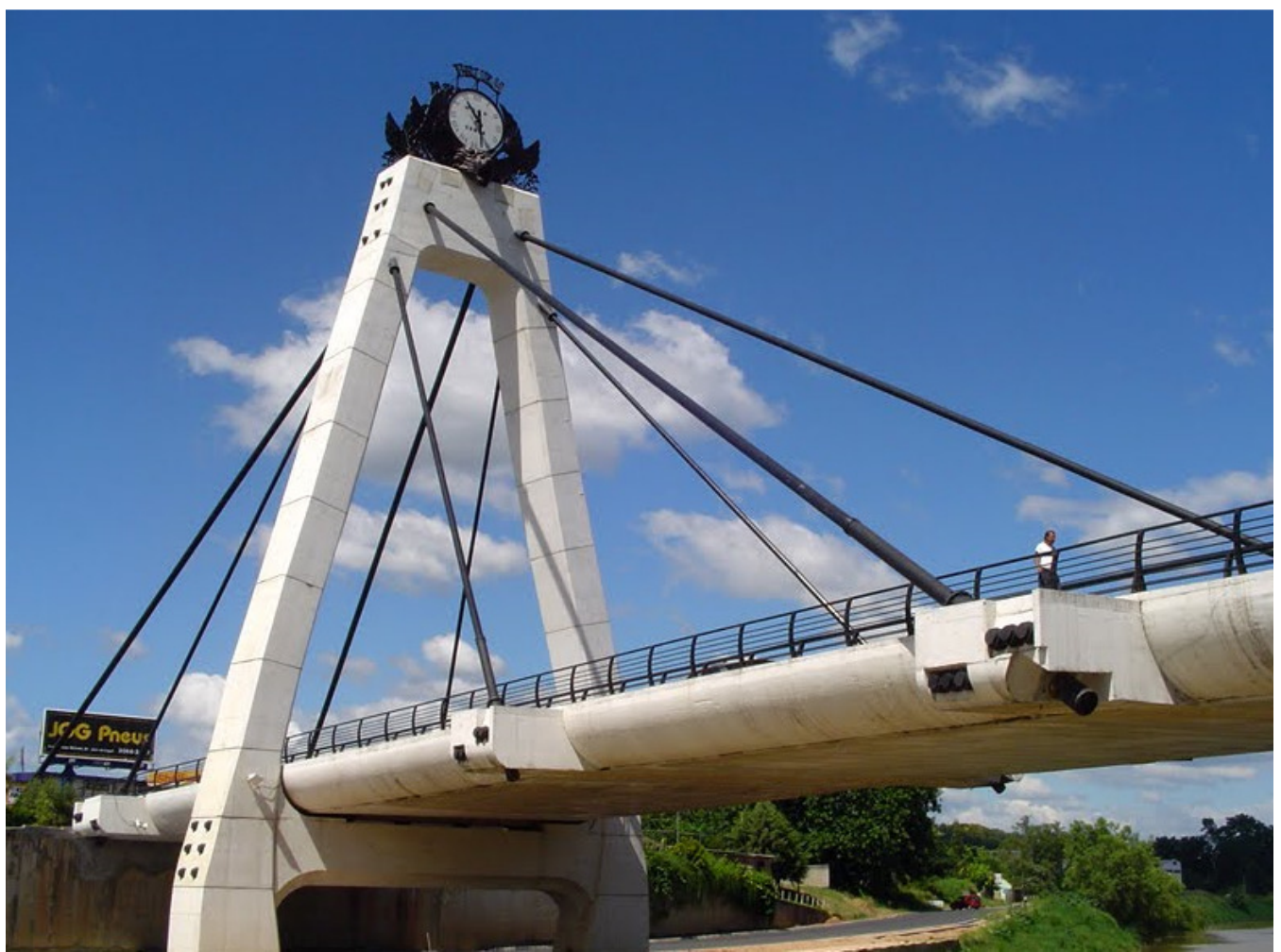

Figura 3.55 - Ponte Irineu Bornhausen (http://www.portalbrusque.com.br)

Localizada em Brusque, em Santa Catarina, a ponte Irineu Bornhausen possui $90 \mathrm{~m}$ de comprimento e foi inaugurada em 2004. O tabuleiro e o mastro da ponte foram executados com concreto branco, sendo a primeira ponte nacional a usar esse material. 


\section{Viaduto Estaiado Cidade de Guarulhos:}

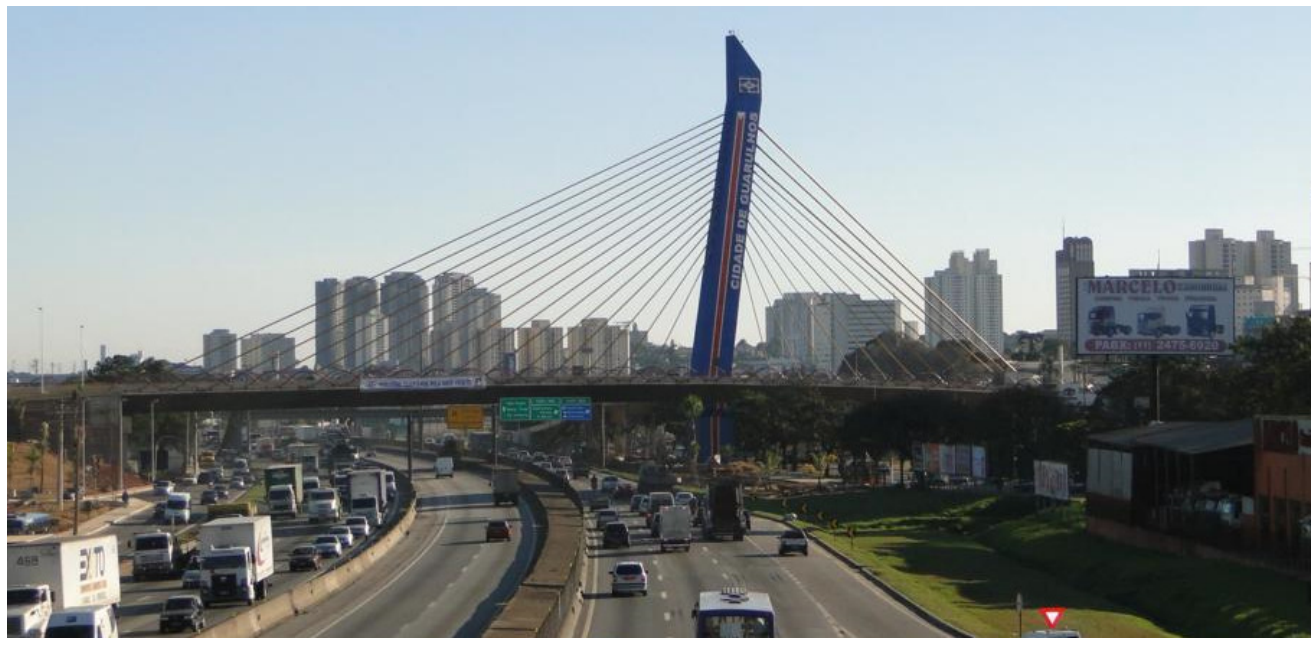

Figura 3.56 - Viaduto Estaiado Cidade de Guarulhos (http://www.skyscrapercity.com/showthread.php?t=506806)

Localizado na cidade de Guarulhos, em São Paulo, o viaduto possui 170 m de extensão e foi inaugurado em 2010. O tabuleiro é suspenso por um único plano central de estais, na geometria semi harpa. O mastro de concreto possui uma altura de $61 \mathrm{~m}$.

\section{Ponte Estaiada sobre o Rio Tietê:}

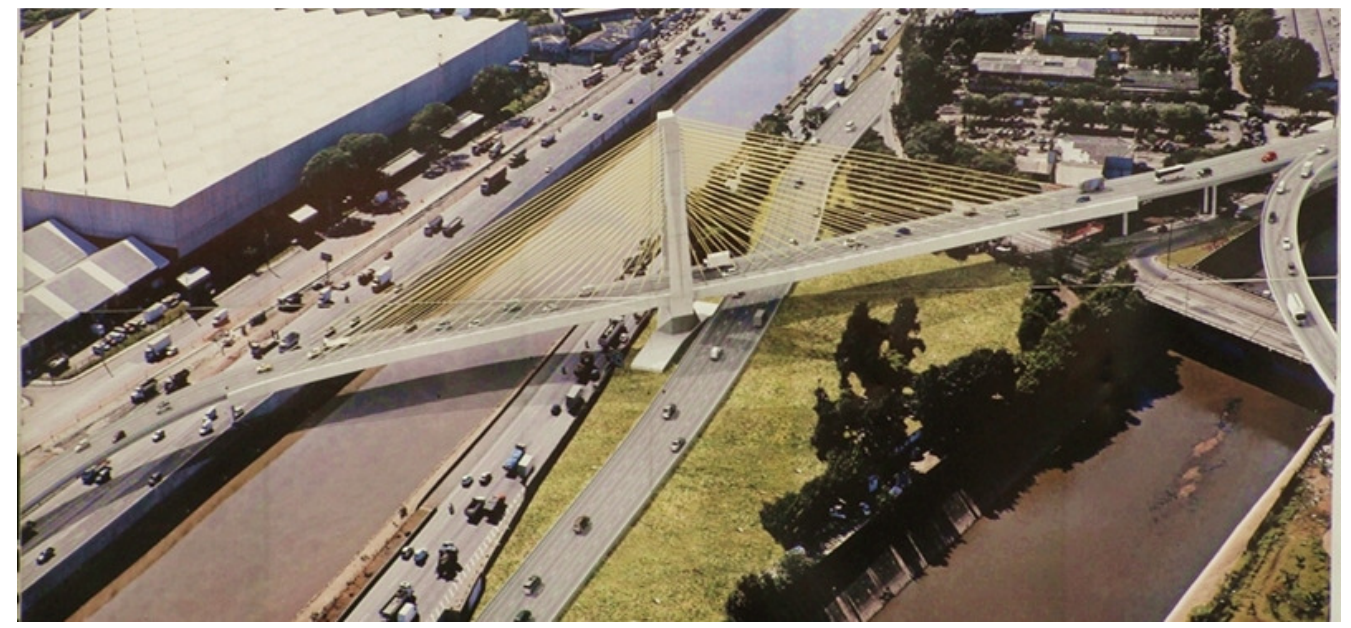

Figura 3.57 - Vista artística da Ponte estaiada sobre o Rio Tietê (http://www.skyscrapercity.com/showthread.php?t=1115903)

Localizada em São Paulo, esta ponte, que recebeu o nome de Complexo Tamanduateí, tem previsão para ser entregue em 2011. A ponte fará a ligação entre a Avenida dos Estados e as pistas da Marginal Tietê sentido Lapa. 


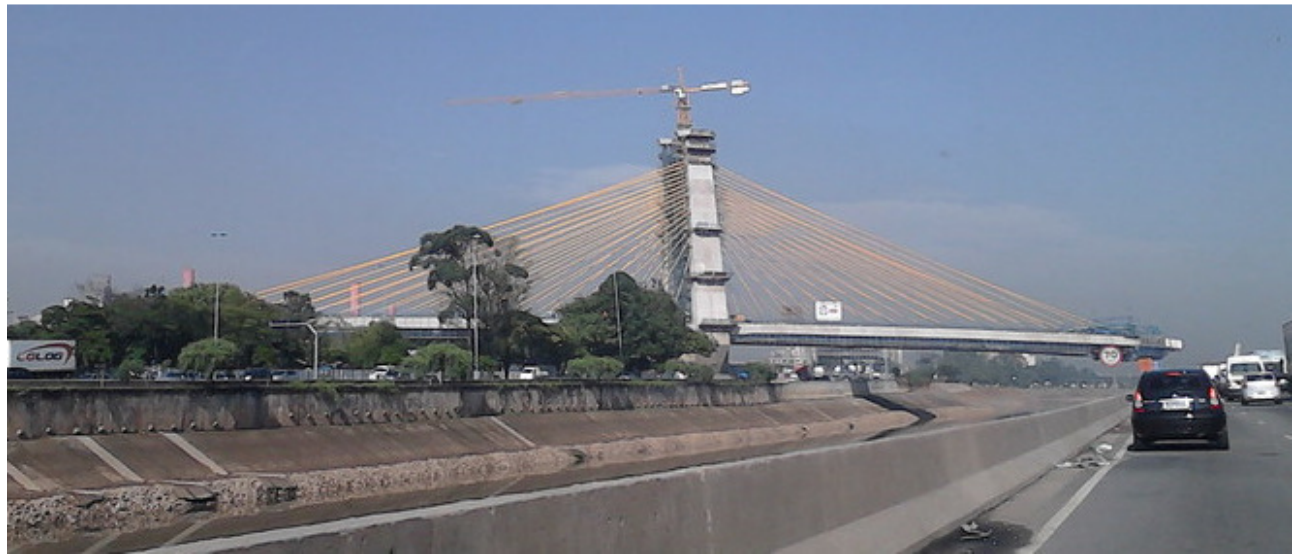

Figura 3.58 - Construção da Ponte estaiada sobre o Rio Tietê (http://www.skyscrapercity.com/showthread.php?t=1115903)

\section{Viaduto Estaiado Padre Adelino:}

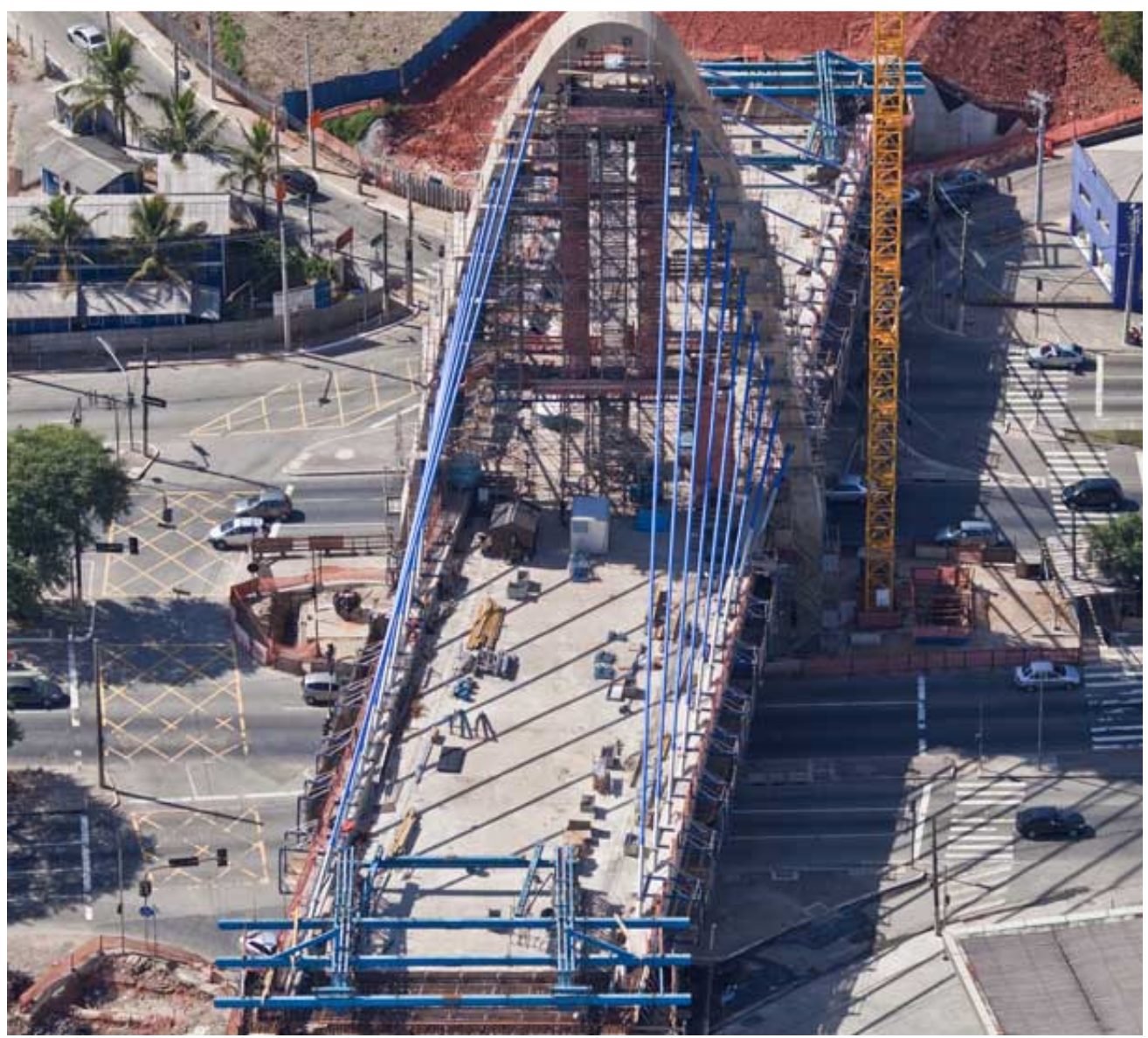

Figura 3.59 - Construção do Viaduto Estaiado Padre Adelino (http://www.skyscrapercity.com/showthread.php?t=552029\&page=7)

Localizado no Tatuapé, em São Paulo, o Viaduto Estaiado Padre Adelino está em construção desde o ano de 2007. Após a conclusão das obras, o viaduto fará a 
ligação dos bairros do Tatuapé e Anália Franco ao Belém e à Mooca, melhorando o fluxo na Radial Leste.

O viaduto possuirá $122 \mathrm{~m}$ de extensão de $20,3 \mathrm{~m}$ de largura. $\mathrm{O}$ mastro de concreto em forma de arco possui $43 \mathrm{~m}$ de altura.

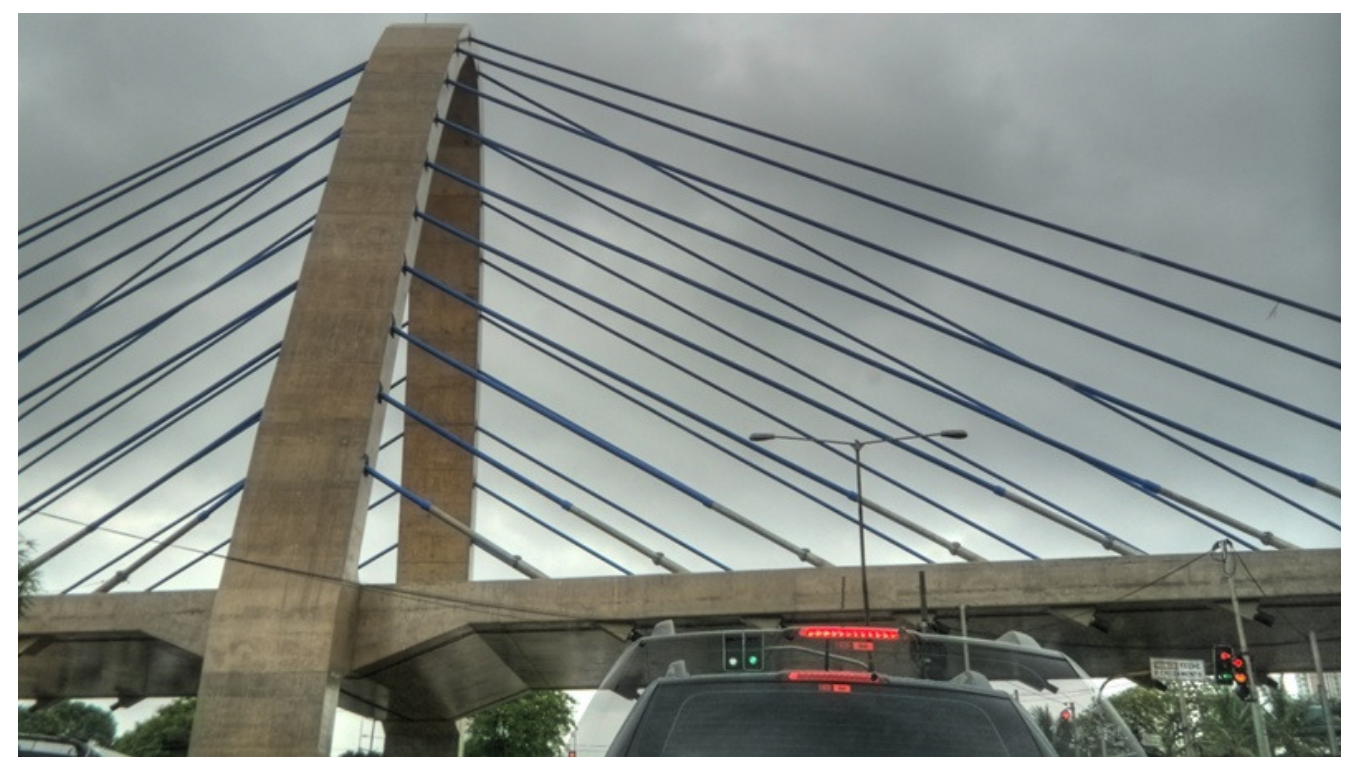

Figura 3.60 - Vista do Viaduto Estaiado Padre Adelino

(http://www.skyscrapercity.com/showthread.php?t=552029\&page=7)

\section{Ponte Estaiada de Barueri}

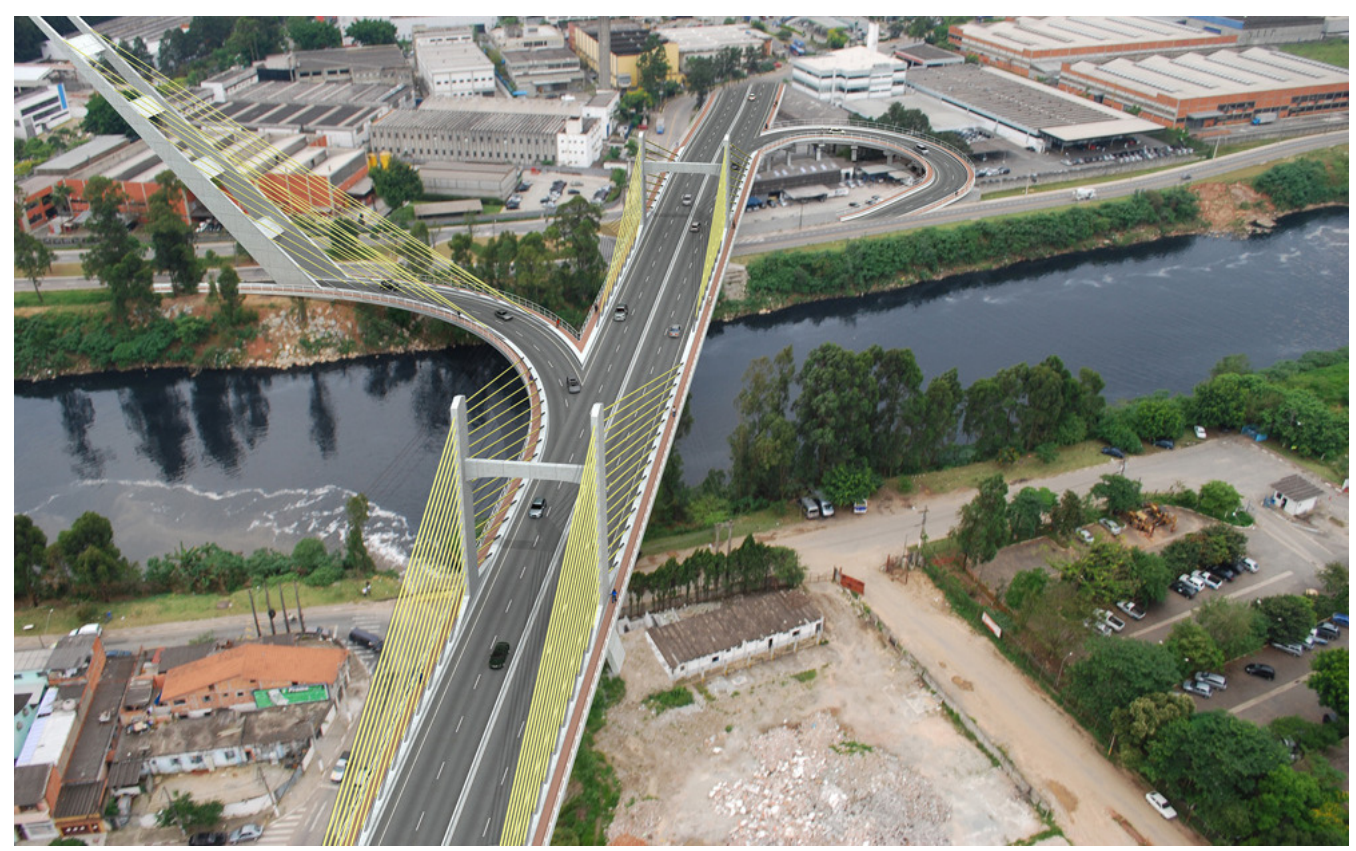

Figura 3.61 - Perspectiva artística da Ponte Estaiada de Barueri (http://www.skyscrapercity.com/showthread.php?p=58633893) 
A prefeitura de Barueri começou a construção de uma ponte estaiada sobre o Rio Tietê, que fará a ligação da Aldeia de Barueri com a estrada da Aldeinha, em Alphaville. A ponte terá $600 \mathrm{~m}$ de extensão e será inteiramente estaiada, com a inovação de que haverá 3 pilares para sustentar a ponte.

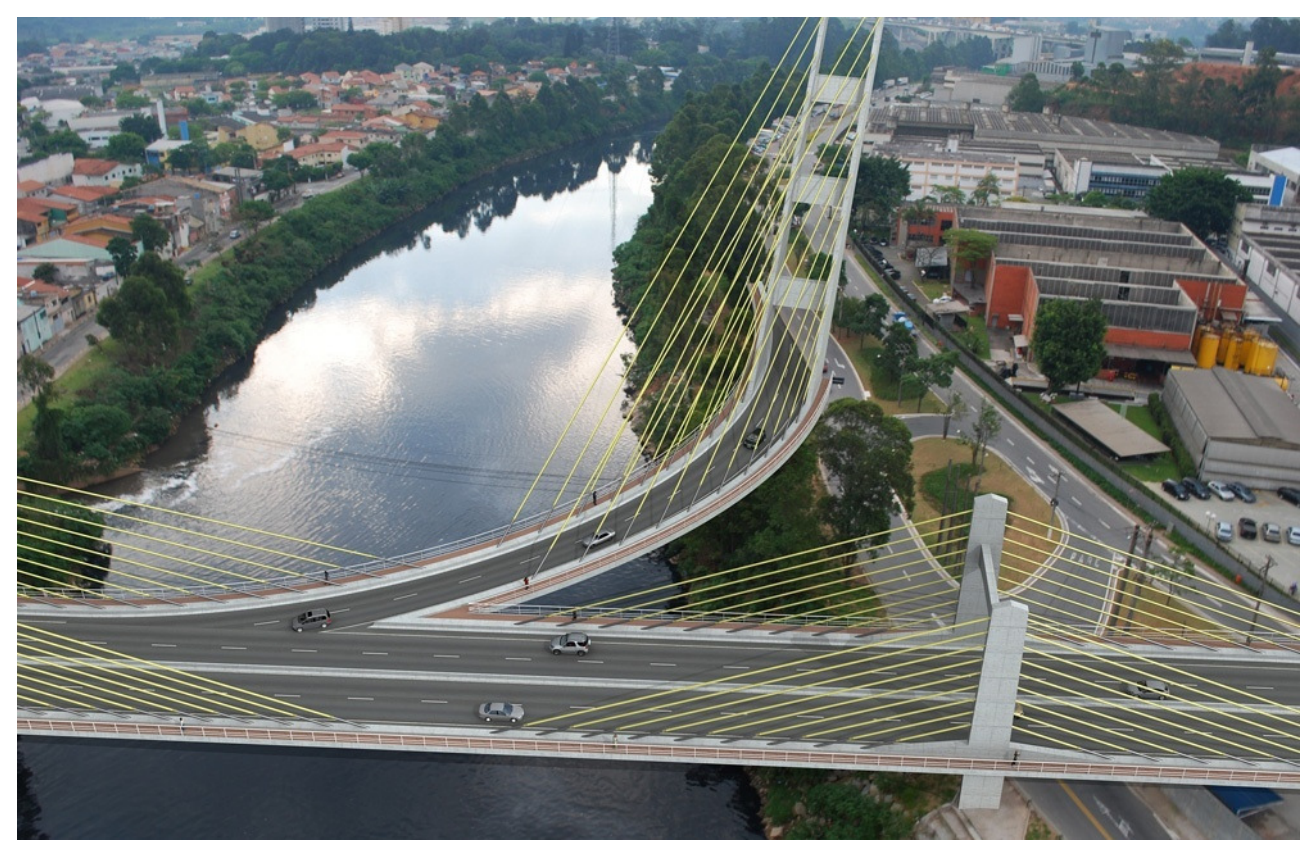

Figura 3.62 - Perspectiva artística da Ponte Estaiada de Barueri (http://www.skyscrapercity.com/showthread.php?p=58633893) 


\section{CONCLUSÃO}

Analisando 0 desenvolvimento das pontes estaiadas, percebe-se uma evolução muito grande, principalmente devido ao aprimoramento dos materiais empregados na construção e das ferramentas matemáticas computacionais utilizadas no dimensionamento.

Esse avanço proporcionou uma grande economia para a execução das pontes estaiadas e uma maior segurança no comportamento estrutural das mesmas. Além disso, a sua utilização tornou-se mais comum, aumentando muito o número de pontes deste tipo construídas pelo mundo. Junto com a evolução tecnológica das pontes estaiadas, houve uma melhora significativa no aspecto visual, tornando estas estruturas mais leves e esbeltas.

No Brasil a utilização das pontes estaiadas é mais recente, uma vez que o domínio da tecnologia por parte de construtoras e calculistas também é recente. Contudo, o Brasil atualmente possui um número considerável de pontes estaiadas e o seu uso encontra-se cada vez mais comum.

Mesmo com o desenvolvimento da engenharia nacional é usual que algumas pontes estaiadas brasileiras sejam projetadas e executadas com a consultoria de calculistas e empresas estrangeiras, que contribuem para a execução de uma obra de qualidade e para um contínuo aprimoramento dos profissionais envolvidos. Com o tempo, a tendência é que essas consultorias diminuam, uma vez que os profissionais brasileiros vão se aperfeiçoando e passam a serem capazes de resolver muitos dos problemas sem a necessidade de uma consultoria estrangeira.

Um fato importante para o Brasil foi à execução da ponte estaiada Octavio Frias de Oliveira, localizada em São Paulo, que colocou o país em lugar de destaque internacional, uma vez que é a primeira ponte estaiada do mundo com dois tabuleiros curvos sustentados por um único mastro. Isso é mais um ponto positivo para a engenharia nacional, que ganha reconhecimento internacional por mais uma conquista.

No Brasil e no mundo as pontes estaiadas são motivo de orgulho para a grande maioria da população das cidades onde são construídas, virando muitas vezes locais de referência e pontos turísticos, agregando valor financeiro e cultural ao local onde são construídas. 
Justamente devido à questão estética, e de ser um motivo de orgulho para as cidades, muitas pontes estaiadas vêm sendo construídas em locais onde esta solução não seria a mais adequada tecnicamente, uma vez que as condições topográficas e os vãos a serem vencidos poderiam ser superados com outros tipos de pontes.

Nota-se que as primeiras pontes estaiadas brasileiras foram construídas com o intuito de superação e inovação, provando que a engenharia nacional seria capaz de realizar um grande feito. Mas atualmente, em alguns casos, esse intuito se perdeu e a motivação passa a ser apenas uma competição entre as cidades e um motivo de orgulho para a sociedade.

Analisando tanto o aspecto estrutural, que possui inúmeras vantagens, quanto o aspecto cultural, as pontes estaiadas já garantiram sua posição na sociedade, tornando-as cada vez mais comuns. A tendência mundial é o aumento da utilização das pontes estaiadas, não só pelo fator técnico-econômico, mas também pelo fator estético. Porém é necessário um bom senso na construção dessas pontes, a fim de que as mesmas não se tornem estruturas exageradas, ficando destoadas do contexto físico e cultural onde estão construídas.

Existem outras soluções estruturais que, quanto realizado um trabalho conjunto entre engenheiros e arquitetos, podem ser tão eficazes e estéticas quanto uma ponte estaiada. A engenharia não deve nunca deixar de inovar, de vencer desafios e se superar, porém cada caso deve ser analisado a fim de que se obtenha a melhor solução técnica e econômica, visando o bem da sociedade e do país. 


\section{REFERÊNCIAS BIBLIOGRÁFICAS}

- ALMEIDA, P. A. O. ; ISHITANI, Hideki ; OYAMADA, Rui N. Forças de implantação nas pontes estaiadas. In: V Simpósio EPUSP sobre Estruturas de Concreto, 2003, São Paulo, 2003.

- GIMSING, N. J. Cable supported bridges : concept and design. Nova Yook : Chichester: 1983. x, $400 \mathrm{p}$.

- ISHII, M. Sistemas estruturais de pontes extradorso. 2006. 90 p. Dissertação (Mestrado) - Escola Politécnica, Universidade de São Paulo, São Paulo, 2006.

- LEITE, W. C. Sistema de cabos nas pontes estaiadas e nas pontes pênseis : bases para o seu dimensionamento. 1991. 2 v. Dissertação (Mestrado) - Escola Politécnica, Universidade de São Paulo, São Paulo, 1991.

- LEONHARDT, F.: ZELLNER, W. Past, present and future of cable-stayed bridges. Stuttgart : Elsevier, 1991.

- LOTURCO, B. - Malha de estais : Complexo viário Real Parque, Téchne, São Paulo. ed. 141. 2008, p.44-51

- PAGliARO, A. C. Pontes estaiadas. 2003. Trabalho de Graduação. - Escola de Engenharia Mauá, Instituto Mauá de Tecnologia, São Caetano do Sul, 2003.

- PFEIL, M. S. Comportamento aeroelástico de pontes estaiadas. 1993. 251 p. Tese (Doutorado) - Engenharia Civil da Universidade Federal do Rio de Janeiro, Rio de Janeiro, 1993.

- PODOLNY, W. ; SCALZI, J. B. Construction and design of cable-stayed bridges, Nova York : Wiley : 1976. xv, 506 p. 
- RYALL, M. J. ; PARKE, G. A. R. ; HARDING, J. E. The manual of bridge engineering. Londres : Thomas Telford, 2007. xxvii, $1012 \mathrm{p}$.

- SANTOS, D. M. Comportamento estrutural de pontes com protensão no extradorso. 2006. 132 p. Dissertação (Mestrado) - Escola Politécnica, Universidade de São Paulo, São Paulo, 2006.

- SANTOS, P. C. O concreto protendido e a ponte estaiada Santo Amaro. 2008. Trabalho de Graduação - Universidade Anhembi Morumbi. São Paulo. 2008. 90 p.

- SOUSA, J. L. A. O. Contribuição ao esrudo de pontes estaiadas. 1984. 1 v. Dissertação (Mestrado) - Escola Politécnica, Universidade de São Paulo, São Paulo, 1984.

- TORNERI, P. - Comportamento estrutural de pontes estaiadas : comparação de alternativas. 2002. 272 p. Dissertação (Mestrado) - Escola Politécnica, Universidade de São Paulo, São Paulo, 2002.

- TROITSKY, M. S. - Cable-stayed bridges : theory and design, Londres : Crosby Lockwood Staples : 1977. xi, 385 p.

- TROYANO, L. F. Bridge engineering : a global perspective. Londres : Thomas Telford : 2003. xix, $775 \mathrm{p}$.

- VARGAS, L. A. B. Comportamento estrutural de pontes estaiadas : efeitos de segunda ordem. 2007. 127 p. Dissertação (Mestrado) - Escola Politécnica, Universidade de São Paulo, São Paulo, 2007.

- WALTHER, R. Cable stayed bridges. Londres : Thomas Telford : 1999. 225 p.

- YTZA, M. F. Q. Métodos construtivos de pontes estaiadas - estudo da distribuição de forças nos estais. 2009. 133 p. Dissertação (Mestrado) - Escola Politécnica, Universidade de São Paulo, São Paulo, 2009. 


\section{- SITES:}

1. Structurae - International Database and Gallery of Structures: site contendo informações técnicas sobre diversos tipos de estruturas.

Disponível em: http://www.structurae.de/

2. Skyscraper City: site contendo informações técnicas, galeria de fotos e discussões técnicas sobre diversos tipos de estruturas.

Disponível em: http://www.skyscrapercity.com/

3. Flickr: site voltado ao compartilhamento de fotos tiradas por fotógrafos profissionais e amadores.

Disponível em: http://www.flickr.com/

4. Wikipedia: enciclopédia digital gratuita.

Disponível em: http://en.wikipedia.org/

5. University of Bristol: site da faculdade de Bristol, na Inglaterra Disponível em: http://www.enm.bris.ac.uk

6. Civil Engineering Societies: site destinado ao compartilhamento de informações técnicas e fotos de estruturas.

Disponível em: http://structure-structural-software.blogspot.com/

7. Analoog Sixty: blog voltado a discussões para fotógrafos profissionais Disponível em: http://analoog60.blogspot.com/

8. The Art of Memory: blog voltado a discussões sobre fotos e filmes antigos. Disponível em: http://theartofmemory.blogspot.com/

9. Venezuela Tuya: site de promoção ao turismo na Venezuela.

Disponível em: http://www.venezuelatuya.com/ 
10. Bridgemeister: site voltado a divulgação de fotos e informações sobre pontes.

Disponível em: http://www.bridgemeister.com

11. Foto Community: site voltado ao compartilhamento de fotos tiradas por fotógrafos profissionais e amadores.

Disponível em: http://www.fotocommunity.com

12. Google Maps: site de busca que permite a visualização de mapas e fotos de satélite.

Disponível em: http://maps.google.com.br/

13. Panoramio: site voltado ao compartilhamento de fotos.

Disponível em: http://www.panoramio.com/ 